\title{
Hydrogeologic Conditions and Simulation of Ground-Water Flow in the Greater Orlando Metropolitan Area, East-Central Florida
}

By L.C. Murray, Jr., and Keith J. Halford

U.S. GEOLOGICAL SURVEY

Water-Resources Investigations Report 96-4181

Prepared in cooperation with the

St. Johns River Water Management District,

South Florida Water Management District, and the Florida Department of Environmental Protection

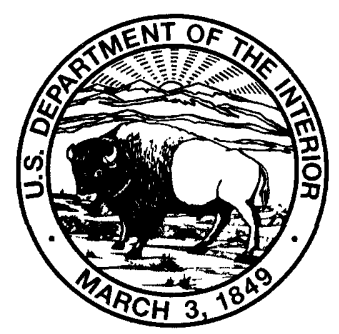




\title{
U.S. DEPARTMENT OF THE INTERIOR \\ BRUCE BABBITT, Secretary
}

\author{
U.S. GEOLOGICAL SURVEY \\ Gordon P. Eaton, Director
}

The use of firm, trade, and brand names in this report is for identification purposes only and does not constitute endorsement by the U.S. Geological Survey

For additional information write to:

Copies of this report can be purchased from:

District Chief

U.S. Geological Survey, WRD

Suite 3015

227 North Bronough Street

U.S. Geological Survey

Branch of Information Services

Tallahassee, FL 32301

Box 25286

Denver, CO 80225-0046 


\section{CONTENTS}

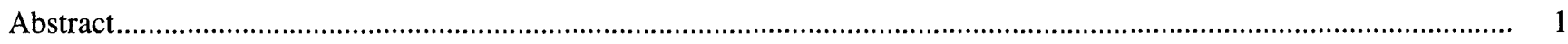

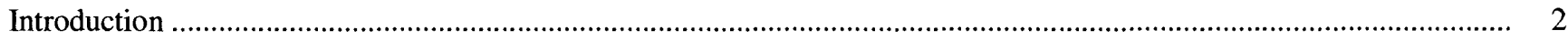

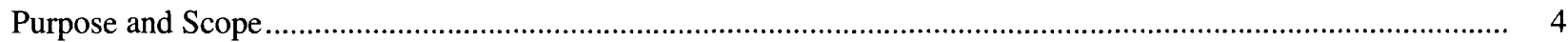

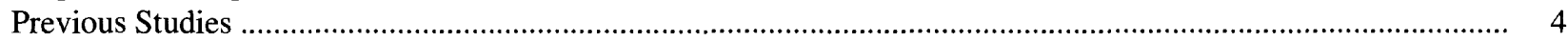

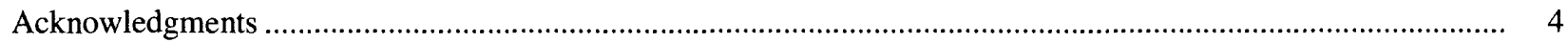

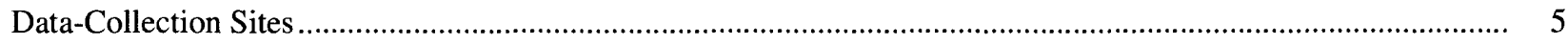

Description of the Area

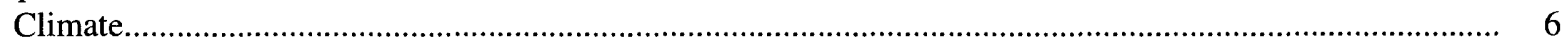

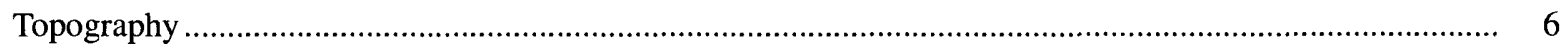

Drainage

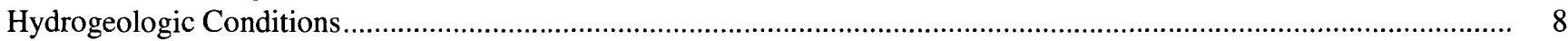

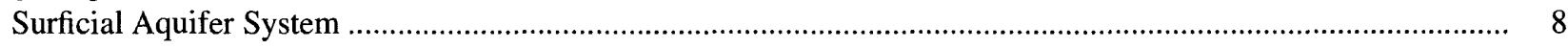

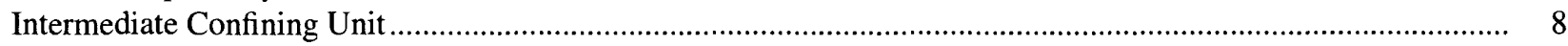

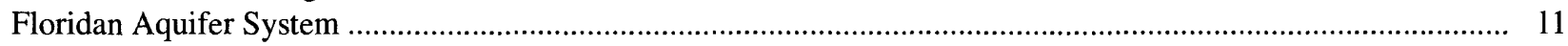

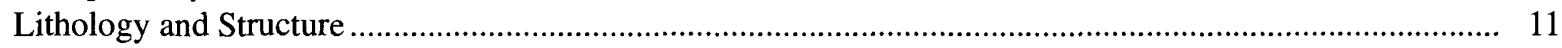

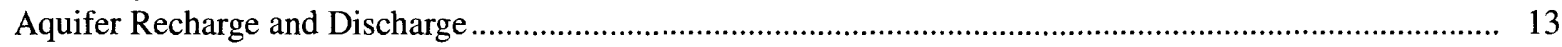

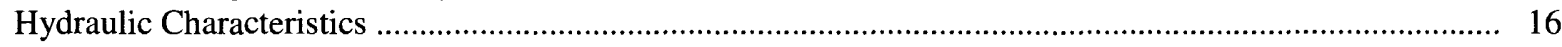

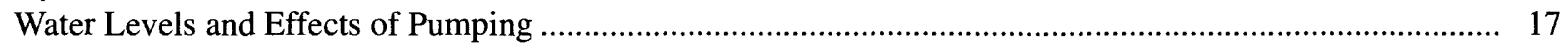

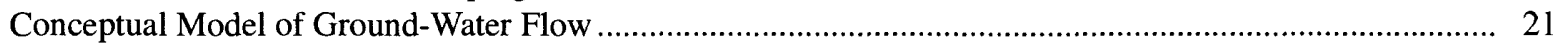

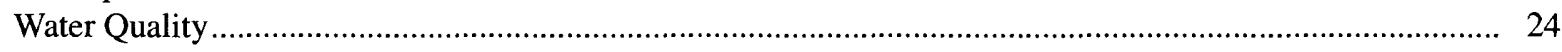

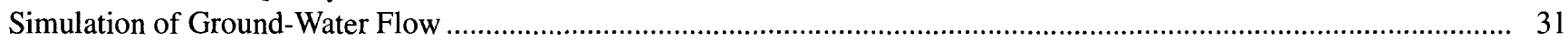

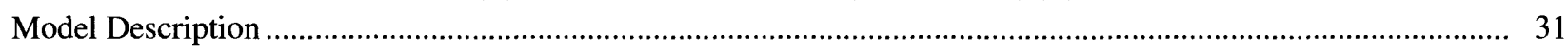

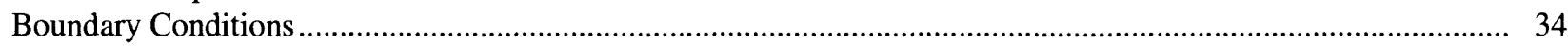

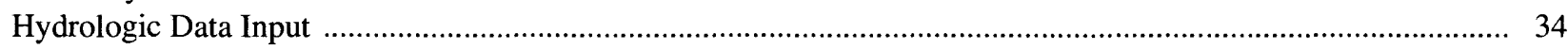

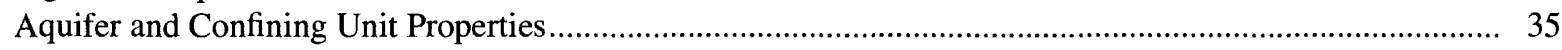

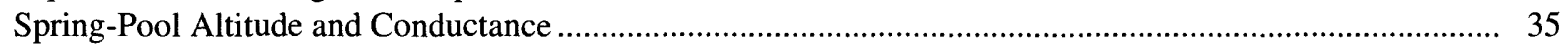

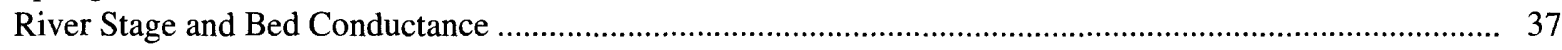

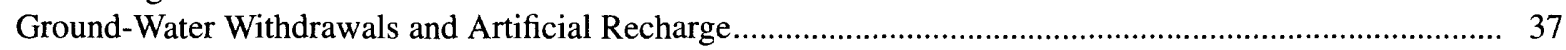

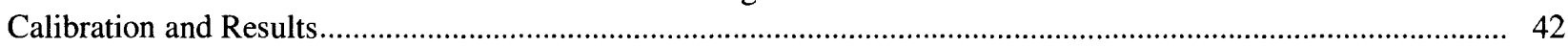

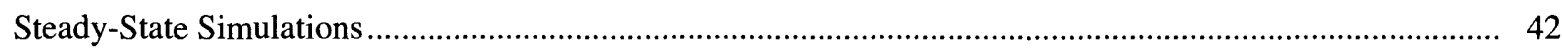

Transient Simulation................................................................................................................ 48

Calibrated Aquifer and Confining-Unit Hydraulic Characteristics ........................................................ 55

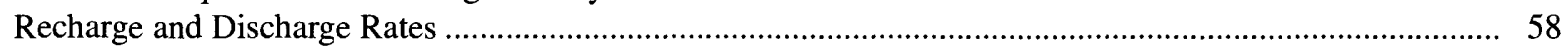

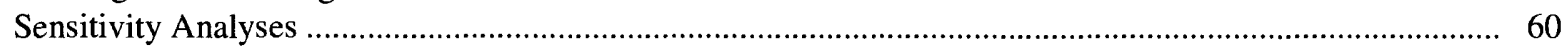

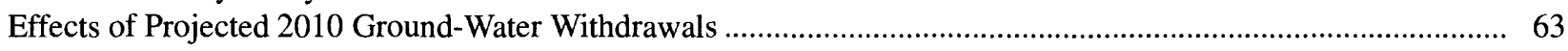

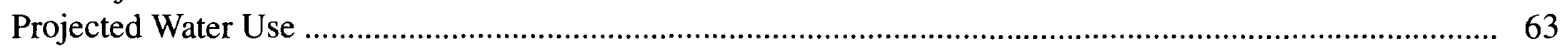

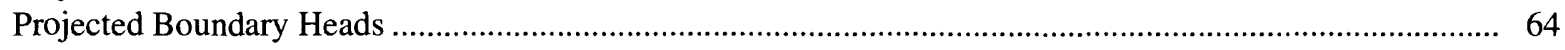

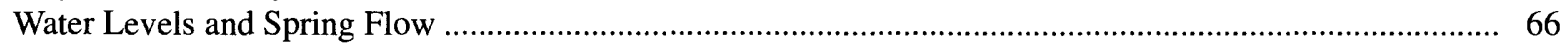

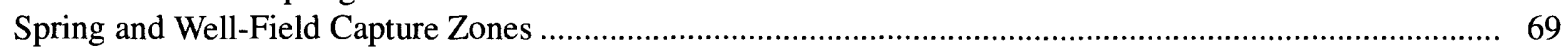

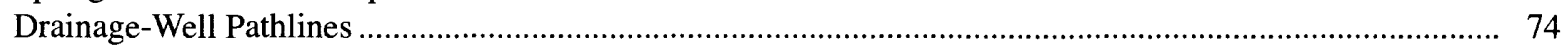

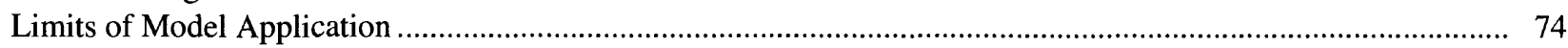

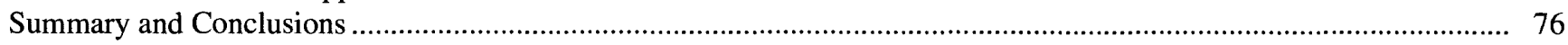

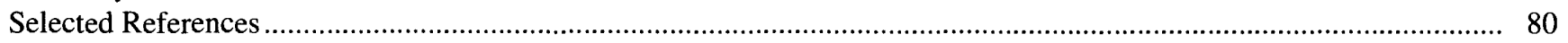

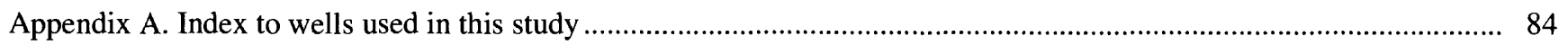

Appendix B. Names and Locations of Lakes and Streams Used in this Study ....................................................... 89

Appendix C. Locations of and Average Daily Withdrawal Rates from Floridan Aquifer System

Municipal/Industrial/Commercial Well Fields Used in Ground-Water Flow Model for 1988,

December 1989 through May 1990, and Projected 2010 Simulations 
1-3. Maps showing:

1. Locations of study area and Upper Floridan aquifer springs

2. Locations of wells used in this study.

3. Generalized topography and major surface-water drainage basins.

4. Chart showing geologic units, hydrogeologic units, and equivalent layers and boundary conditions used in the ground-water flow model

5-8. Maps showing:

5. Generalized thickness of the intermediate confining unit

6. Altitude of the top of the Upper Floridan aquifer.

7. Generalized distribution of recharge to and discharge from the Upper Floridan aquifer and results of selected aquifer tests

8. Potentiometric surface of the Upper Floridan aquifer prior to extensive ground-water development and water levels measured at selected Upper Floridan aquifer monitoring wells in the early 1930's

9. Plots showing pumpage from Floridan aquifer system by Orlando and Winter Park (1951-93), water levels in Upper Floridan aquifer monitoring well OR 47 (1944-93), and discharge of water from Wekiva Springs (1944-91)

10. Map showing average 1988 Upper Floridan aquifer potentiometric surface and drawdowns relative to predevelopment conditions.

11. Plot showing average rainfall for Orlando and Sanford and water levels in Upper Floridan aquifer monitoring well OR-47, 1978-92

12. Sketch showing hydrogeologic section and conceptualized ground-water flow along model row 10 , columns 1-55

13-15. Maps showing:

13. Dissolved solids concentrations in water in the Upper Floridan aquifer

14. Chloride concentrations in water in the Upper Floridan aquifer and estimated depth to water containing chloride concentrations greater than 10,000 milligrams per liter.

15. Sulfate concentrations in water in the Upper Floridan aquifer

16. Trilinear diagram of major cations and anions in water from Upper Floridan aquifer springs

17. Plot showing specific conductance of water discharged from Wekiva Springs, 1956-93

18. Plot showing chloride concentrations in water from zones penetrating the Upper and Lower Floridan aquifers at monitoring well Cocoa C, 1966-94

19. Map showing finite-difference grid superimposed on modeled area and locations of Drain and River cells

20. Map showing estimated range of declines in surficial aquifer heads, average 1988 conditions to May 1990

21-26. Maps showing:

21. Distribution of average 1988 Upper Floridan aquifer pumpage

22. Distribution of average 1988 Lower Floridan aquifer pumpage

23. Distribution of recharge to the Upper Floridan aquifer from drainage wells (calibrated) and rapid-infiltration basins (measured) for average 1988 steady-state conditions

24. Simulated Upper Floridan aquifer potentiometric surface for predevelopment steady-state conditions and water levels measured at selected Upper Floridan aquifer monitoring wells in the early 1930's

25. Simulated Upper Floridan aquifer potentiometric surface for average 1988 steady-state conditions and water levels measured at Upper Floridan aquifer monitoring wells

26. Simulated Lower Floridan aquifer potentiometric surface for average 1988 steady-state conditions and water levels measured at selected Lower Floridan aquifer monitoring wells.

27. Plots showing differences between simulated and measured water levels in the Upper Floridan aquifer for average 1988 steady-state conditions.

28. Schematic diagram showing observed and simulated hydrologic budgets for steady-state predevelopment and average 1988 conditions ......

29-32. Hydrographs showing observed and simulated water levels in selected Upper Floridan aquifer monitoring wells, January 1 to May 25, 1990:

29. Lake Oliver well, Sea World well, and Bay Lake well 
30. Bithlo well, Lake Joel well, and OR-47 well

31. Cocoa A well, Cocoa $P$ well, and Champion well

32. Geneva well, Seminole 125 well, and Seminole 257 well

33. Map showing simulated Upper Floridan aquifer potentiometric surface (May 25, 1990), water levels measured at Upper Floridan aquifer monitoring wells, and observed drawdowns relative to average 1988 conditions.

34. Plots showing measured and simulated drawdowns in Upper Floridan aquifer monitoring wells, average 1988 conditions to May 25, 1990

35-39. Maps showing:

35. Calibrated leakance of the intermediate confining unit....

36. Calibrated transmissivity of the Upper Floridan aquifer and results of selected aquifer tests

37. Calibrated leakance of the middle semiconfining unit of the Floridan aquifer system

38. Calibrated transmissivity of the Lower Floridan aquifer and results of selected aquifer tests.......

39. Simulated rates of recharge to and discharge from the Upper Floridan aquifer through the intermediate confining unit and lateral flow to and from the Upper Floridan aquifer across model boundaries, average 1988 steady-state conditions....

40. Plot showing sensitivity of Upper Floridan aquifer heads and spring flow to variations in calibrated model parameters and in specified surficial-aquifer heads

41-48. Maps showing:

41. Distribution of projected 2010 Upper Floridan aquifer pumpage and location of new well field

42. Distribution of projected 2010 Lower Floridan aquifer pumpage

43. Simulated Upper Floridan aquifer potentiometric surfaces for projected 2010 wet and dry conditions

44. Simulated Upper Floridan aquifer drawdowns from 1988 to the year 2010 for projected wet and dry conditions

5. Simulated drawdown in the Upper Floridan aquifer attributed to the increase in Lower

Floridan aquifer pumpage from 1988 to 2010 (wet and dry conditions).

46. Approximate areas contributing water to the Cocoa well field in 1988 and to Upper Floridan aquifer springs from the base of the surficial aquifer system, average 1988 and projected 2010 wet conditions.

47. Approximate areas contributing water to the Cocoa well field and the Orange County eastern regional well field from the base of the surficial aquifer system, projected 2010 wet conditions.

48. Simulated pathlines of ground-water flow in the Floridan aquifer system from the Lake Killarney and Lake Underhill drainage wells during average 1988 steady-state conditions, and generalized capture area for particles for projected 2010 wet conditions.

\section{TABLES}

1. Discharge from selected Upper Floridan aquifer springs in the Orlando metropolitan area for 1988 and predevelopment steady-state conditions

2. Average 1988 lake water levels based on monthly observations and lake water levels estimated from USGS quadrangle maps.

3. Typical concentrations of dissolved solids, hardness, sulfate, and chloride in freshwater, brackish water, and seawater

4. Chloride, sulfate, and dissolved solids concentrations in selected Upper Floridan aquifer springs, May 1993, and average values.

5. Model-input data.

6. Water use during average 1988 conditions, January-May 1990, and projected 2010 conditions..

7. Estimated application rates for agricultural irrigation for average 1988 and January-May 1990 40

8. Measured or estimated discharge and simulated discharge from selected Upper Floridan aquifer springs during predevelopment, average 1988, and May 25, 1990 conditions

9. Simulated discharge from selected Upper Floridan aquifer springs during average 1988 and projected 2010 steady-state wet and dry conditions

10. Simulated water budgets for the Upper and Lower Floridan aquifers during average 1988 and projected 2010 steady-state wet and dry conditions 


\title{
Hydrogeologic Conditions and Simulation of Ground-Water Flow in the Greater Orlando Metropolitan Area, East-Central Florida
}

\author{
by L.C. Murray, Jr., and Keith J. Halford
}

\section{ABSTRACT}

A finite-difference ground-water flow model was used to simulate the effects of both modern-day (1988) and projected 2010 ground-water withdrawals on the Floridan aquifer system in the greater Orlando metropolitan area. This area covers about 2,500 square miles and includes all of Orange and Seminole Counties and parts of Lake, Volusia, Brevard, Osceola, and Polk Counties.

The hydrogeology of the area is characterized by a thin surficial aquifer underlain by the thick, highly productive rocks of the Floridan aquifer system. Water in the Upper Floridan aquifer is brackish (chloride concentrations greater than 1,000 milligrams per liter) in discharge areas beneath and near the St. Johns and Wekiva Rivers and is freshest (chloride concentrations less than 100 milligrams per liter) in recharge areas. A slight trend toward increasing concentrations of dissolved solids, chloride, and sulfate has been observed at Upper Floridan aquifer springs. Chloride concentrations in the Upper Floridan aquifer measured between 1966 and 1993 at the Cocoa well field have increased from 50 milligrams per liter to 120 milligrams per liter; concentrations measured in the Lower Floridan aquifer between 1966 and 1993 have increased from 600 milligrams per liter to 3,000 milligrams per liter.

The flow model was calibrated by comparing (a) simulated and estimated Upper Floridan aquifer predevelopment (unstressed) potentiometric surfaces, (b) simulated and measured heads at 142 Upper Floridan aquifer monitoring wells in
1988 (average absolute error of 1.8 feet), (c) simulated and measured discharge rates at 15 Upper Floridan aquifer springs in 1988 (306 cubic feet per second), and (d) simulated and measured drawdowns at 134 Upper Floridan aquifer monitoring wells between 1988 and May 1990 (58 and 95 percent of simulated drawdowns were within plus or minus 25 and 50 percent of measured drawdowns, respectively). Relative to predevelopment conditions, model simulations indicate that about half of the 305 million gallons per day of water pumped from the Floridan aquifer system in 1988 was accounted for by increased recharge from the surficial aquifer system. About 23 cubic feet per second was derived from increased lateral inflow. A storage coefficient of $1 \times 10^{-3}$ provided the best comparisons of measured-to-simulated data during the transient simulation from January to May 1990 . This storativity probably is greater than the true storativity of the Upper Floridan aquifer because storage contributions from the intermediate confining unit were not accounted for during model design and development.

Calibrated transmissivity ranged from 10,000 to greater than 400,000 feet squared per day in the Upper Floridan aquifer, and from 5,000 to 600,000 feet squared per day in the Lower Floridan aquifer. Calibrated intermediate confining unit leakance ranged from $1 \times 10^{-5}$ to $4 \times 10^{-3}$ per day and was highest in areas where the unit is thin or has been breached by numerous sinkholes. In general, calibrated transmissivity and leakance values were higher than associated aquifer-test values. Simulated recharge rates to 
the Upper Floridan aquifer from the surficial aquifer system ranged from less than 3 to 21 inches per year. Recharge rates of greater than 10 inches per year were simulated in areas of west Seminole, west Orange, east Lake, and southwest Volusia Counties. Recharge rates of less than 3 inches per year were simulated in east Orange and northeast Osceola Counties.

The calibrated model was used to simulate the effects of increased Floridan aquifer withdrawals in the year 2010 (542 million gallons per day) on water levels and spring flow. Projected effects were simulated for both "wet" conditions (using 1988 fixed-head arrays) and for "dry" conditions (using May 1990 fixed-head arrays), thus bracketing a potential range of effects. Relative to simulated 1988 conditions, simulated 2010 spring flow decreased by 43 cubic feet per second (14 percent) for wet conditions and by 67 cubic feet per second ( 22 percent) for dry conditions. Increased pumpage from the Lower Floridan aquifer accounted for about 17 cubic feet per second (40 percent) of reduced spring-flow rates. Simulated drawdowns in the Upper Floridan aquifer ranged from 10 to 20 feet in central Orange County, with a local maximum of about 30 feet at a well field in southwest Orange County. About 4 to 8 feet of the drawdown simulated in central Orange Country was attributed to increased Lower Floridan aquifer pumpage. Simulated drawdowns ranged from less than 2 feet in east Seminole County to about 10 feet in the south-central part of the county.

Particle-tracking simulations indicate that water discharged at Seminole, Messant, Rock, Wekiva, Miami, Sanlando, Palm, and Starbuck Springs is derived largely from high-rate recharge areas in northwest Orange and east Lake Counties. Water pumped from the Cocoa well field in 1988 was captured from low-rate recharge areas in central Orange and north Osceola Counties. Pumpage from the proposed Orange County eastern regional well field in 2010 captured much of the water in central Orange County that contributed to the Cocoa well field in 1988. As a result, the projected Cocoa well field contributing area was displaced further south, capturing more water from Osceola County and less water from Orange County.

The simulated flow paths and destinations of surface waters that recharge the Upper Floridan aquifer through the Lake Killarney and Lake Underhill drainage wells ( 2.5 and 2.1 million gallons per day, respectively) were significantly affected by increased 2010 withdrawals. About 70 percent of inflow to these wells in 1988 moved toward the northeast and was discharged in east Seminole County, either to the surficial aquifer system or to the St. Johns River. In 2010, about 95 percent of the simulated inflow was captured and discharged by three Lower Floridan aquifer well fields located in north-central Orange County. The remaining 5 percent was captured and discharged by two Upper Floridan aquifer well fields in north-central Orange County.

\section{INTRODUCTION}

The Orlando metropolitan area includes all of Orange and Seminole Counties and adjacent parts of Lake, Volusia, Brevard, Osceola, and Polk Counties (fig. 1). Virtually all the water required to meet municipal, industrial, commercial, and agricultural demands in the area is pumped from the Floridan aquifer system. Withdrawals from the Floridan aquifer system are regulated by the St. Johns River and South Florida Water Management Districts.

The population of the Orlando metropolitan study area has increased by about 50 percent since 1980 and was estimated at about 1.3 million people in 1994. Projected population and commercial growth are expected to increase demands on the ground-water resource. Favorable areas for future ground-water development are limited by the presence of saltwater, zones of relatively low aquifer transmissivity, and by the proximity of existing well fields. Increased withdrawals also could lower the potentiometric surface of the Upper Floridan aquifer and decrease the flow from Upper Floridan aquifer springs, which are valuable recreational and aesthetic resources. Springs in the study area are identified in figure 1 .

The long-term effects of increased ground-water withdrawals on the Floridan aquifer system are difficult to evaluate because previous ground-water flow models of east-central Florida did not encompass the 

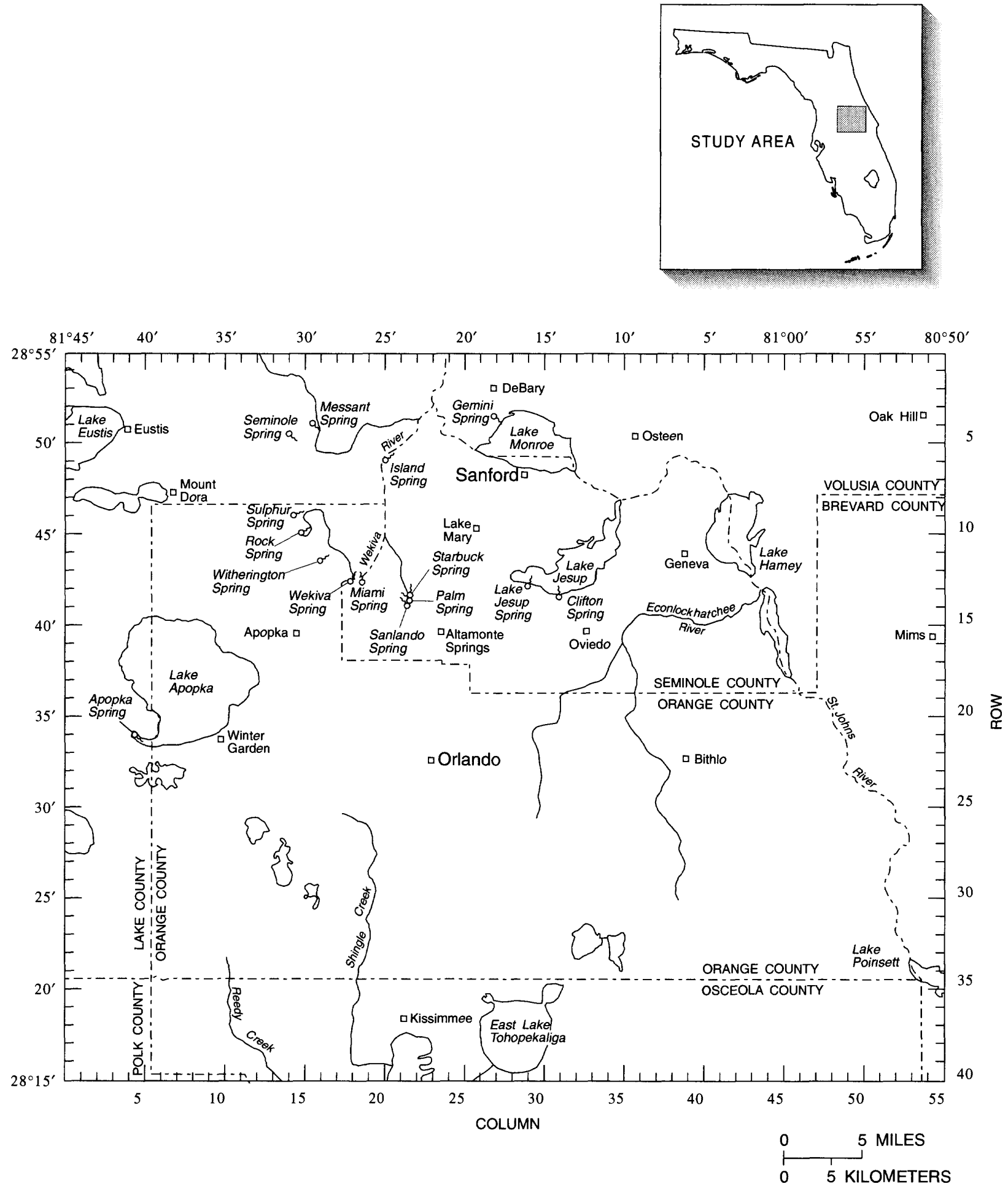

Figure 1. Locations of study area and Upper Floridan aquifer springs. 
entire metropolitan Orlando area or were more regional in scope and coarsely discretized. Although the earlier Regional Aquifer-System Analysis (RASA) study conducted by the U.S. Geological Survey (Tibbals, 1981; 1990) includes the study area, the RASA model is coarsely discretized and was developed to simulate more regional flow systems. In order to improve understanding of ground-water flow conditions in the Floridan aquifer system and the possible effects of future withdrawals, the U.S. Geological Survey (USGS), in cooperation with the St. Johns River Water Management District (SJRWMD), the South Florida Water Management District (SFWMD), and the Florida Department of Environmental Protection (FDEP), began a 5-year project to develop and calibrate a more highly resolved digital ground-water flow model of the study area.

\section{Purpose and Scope}

This report describes the results of a cooperative study designed to (1) update information on the hydrogeologic and water-quality conditions in the Floridan aquifer system in the study area; (2) estimate, by computer simulation, the hydraulic characteristics of the confining units and aquifers that underlie the study area and the distribution of Upper Floridan aquifer recharge rates from the surficial aquifer system; and (3) to assess the possible effects of projected 2010 ground-water withdrawals on flow conditions in the Floridan aquifer system.

Many of the data referenced in this study were collected since the RASA study was completed. Together with the existing data, these more recent data were used to develop a conceptual model of the ground-water flow system in the study area. A digital computer model constructed from the conceptual model was used to simulate (a) the steady-state flow conditions observed in the Floridan aquifer system prior to extensive ground-water development;

(b) modern-day (1988) stressed conditions;

(c) declines in Upper Floridan aquifer heads observed during a period of deficient rainfall from January through May 1990; and (d) the effects of increased Floridan aquifer pumpage in the year 2010 on water levels and spring discharge from the Upper Floridan aquifer. Generalized water budgets were developed and used to compare historic and projected flow conditions within and between the Upper and Lower Floridan aquifers. Particle-tracking simulations were used to delineate areas that contribute recharge to selected Upper Floridan aquifer springs and well fields during 1988 and projected 2010 conditions. The possible routes and destinations of surface water that recharges the Upper Floridan aquifer through two high-capacity drainage wells located near downtown Orlando also were simulated.

\section{Previous Studies}

The results of regional, multistate studies of the Floridan aquifer system have been described by Miller (1986); Johnston and Bush (1988); and Bush and Johnston (1988). Johnston and others (1980) constructed a potentiometric surface map of the Upper Floridan aquifer in the southeast United States as it existed prior to extensive ground-water development. Maps showing the current potentiometric surface of the Upper Floridan aquifer in central Florida are published semiannually by the USGS. Investigations have been conducted in all or parts of Orange County by Stringfield (1936a), Unklesbay (1944), Lichtler and others (1968), Lichtler (1972), Knochenmus (1975), Tibbals and Frazee (1976), Watkins (1977), Kimrey (1978), Shaw and Trost (1984), German (1989), Toth and others (1989), and Bradner (1991); in Seminole County by Barraclough (1961, 1962), Anderson and Hughes (1975), Tibbals (1977), Phelps and Rohrer (1987), and Toth and others (1989); in Volusia County by Wyrick (1960), Knochenmus and Beard (1971), Rutledge (1982, 1985), McGurk and others (1989), Kimrey (1990), Phelps (1990), and Vecchioli and others (1990); in Lake County by Knochenmus and Hughes (1976), Grubb (1978), Grubb and Rutledge (1979), Johnson (1979), and Toth and others (1989); in Osceola County by Frazee (1980), Shaw and Trost (1984), and Schiner (1993); in Polk County by Stewart (1966), Grubb (1978), Grubb and Rutledge (1979), Johnson (1979), and Barr (1992); and in Brevard County by Brown and others (1962). Ground-water flow modeling studies have been performed for all or parts of the study area by Bush (1978), Grubb and Rutledge (1979), Planert and Aucott (1985), Skipp (1988), and Tibbals (1981,1990).

\section{Acknowledgments}

The authors wish to thank Barbara Vergara and Douglas Munch (SJRWMD); Keith Smith (SFWMD); 
and Rodney DeHan (FDEP) and their respective staffs for assistance in this investigation.

\section{Data-Collection Sites}

Wells inventoried by the USGS are assigned a unique identification number based on latitude and longitude. Wells identified by other sources are assigned the number given in the respective reference. The locations of wells used in this study are shown in figure 2. Sites related to well data used in this study are listed in Appendix A. Most surface-water data-collection sites are identified by the USGS using an 8 -digit number sequenced in downstream order. Sites related to surface-water data used in this study are listed in appendix B.

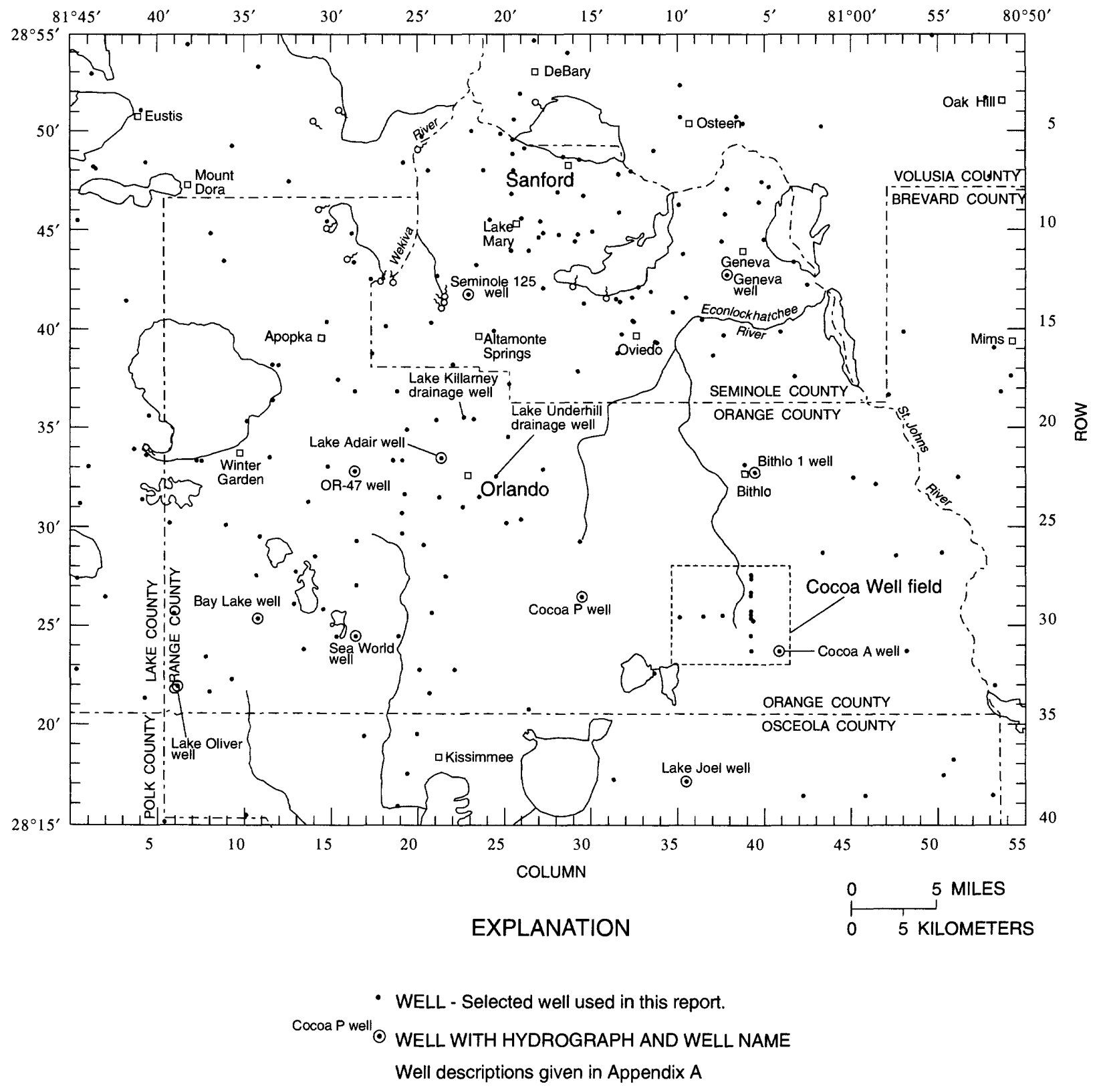

Figure 2. Locations of wells used in this study. 


\section{Description of the Area}

The study area encompasses $2,500 \mathrm{mi}^{2}$ in east-central Florida and includes all of Orange and Seminole Counties and parts of Lake, Volusia, Brevard, Osceola, and Polk Counties (fig. 1). The principal industries of the area are tourism, agriculture, space research, and light manufacturing. Agricultural products include citrus, cattle, vegetables, ornamental plants, poultry, timber, and pulpwood.

\section{Climate}

The climate of the study area is classified as subtropical and is characterized by warm, relatively wet summers and mild, relatively dry winters. Temperatures commonly exceed $90^{\circ} \mathrm{F}$ during June, July, August, and September, but may fall below freezing for a few days in the winter months. The average annual air temperature in Orlando is about $72^{\circ} \mathrm{F}$. Long-term (1913-92) annual rainfall for the area is about $51 \mathrm{in}$. (averaged from rainfall data collected at Orlando and Sanford). About 55 percent of the yearly total is derived from thunderstorms that occur frequently during the months of June, July, August, and September. Thunderstorms usually are localized and distribute rainfall unevenly across the area. During the winter, rainfall usually is associated with cold fronts and is more uniformly distributed than during the rest of the year.

\section{Topography}

Topography in the study area ranges from the rolling highlands of east Lake and west Orange Counties to the flat, swampy lowlands of the St. Johns River flood plain in east Orange and west Brevard Counties. The landscape across much of the study area is characterized by hundreds of lakes and several large streams. Water levels measured in over 100 lakes were used to help define water-table altitudes in the study area, as discussed later in this report. Land-surface altitudes along the northwest-to-southeast oriented highland ridges in Orange and Lake Counties range from 150 to about $300 \mathrm{ft}$ (fig. 3). The highland areas contain numerous lakes and karst features, such as depressions and sinkholes, many of which do not have surface outlets and are internally drained. Numerous depressions also are present along sandy ridges in west Volusia County, north of Lake Monroe and to the east of the St. Johns River.
The southwest part of the study area in Polk County, although topographically high, is relatively flat and swampy. Land-surface altitudes in the area range from 125 to $150 \mathrm{ft}$. Moderate topography dominates much of central Orange, north Osceola, and west Seminole Counties. Altitudes in these areas generally range from 50 to $100 \mathrm{ft}$, but altitudes are greater than $100 \mathrm{ft}$ around Orlando and less than $50 \mathrm{ft}$ in northeast Osceola County. Except for the higher sandy ridges in Volusia and Brevard Counties and a small area surrounding the town of Geneva in Seminole County, altitudes near the coastal areas and around the St. Johns River range from 0 to $50 \mathrm{ft}$.

\section{Drainage}

The study area is divided into three major drainage basins: the St. Johns River basin, the Kissimmee River basin, and the Coastal basin (fig. 3). The St. Johns River basin is subdivided into numerous smaller subbasins; however, for the purposes of this report, only the Upper St. Johns and Ocklawaha River subbasins are shown in figure 3 . Detailed descriptions of surface-water drainage and subbasin delineations in east-central Florida are described by Lichtler $(1968,1972)$.

The most prominent surface-water feature in the study area is the St. Johns River. The river flows southeast-to-northwest across the study area and defines the eastern boundaries of Seminole and Orange Counties. The St. Johns River discharges into the Atlantic Ocean near Jacksonville in northeast Florida, but the river is tidally influenced as far upstream as Seminole County. About two-thirds of the study area is drained by the river, including all of Seminole County, the east and northwest parts of Orange County, and parts of Osceola, Brevard, Volusia, and Lake Counties. Major tributaries within the St. Johns River basin are the Econlockhatchee River and the Ocklawaha River. The Ocklawaha River subbasin drains northwest Orange and east Lake counties. This subbasin contains few surface streams and drainage is mostly into closed depressions or lakes. The Upper St. Johns River subbasin drains all of Seminole County, east Orange, and parts of Osceola, Brevard, Volusia, and Lake Counties. Surface water in much of east-central Orange and east Seminole Counties drains to the Econlockhatchee River. Drainage within these areas, which are characterized by high water tables and numerous small streams, is more developed than in the Ocklawaha subbasin. 


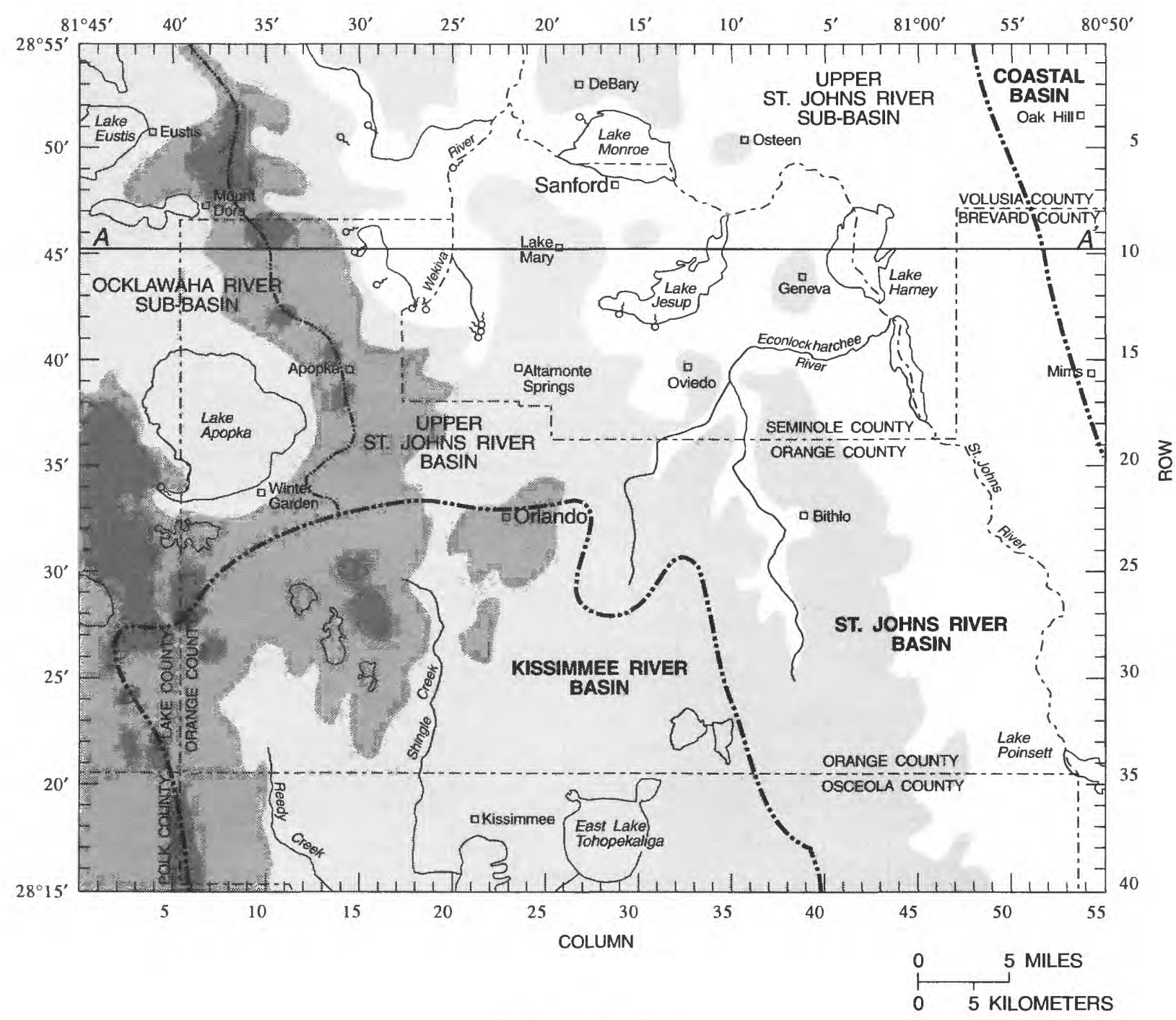

EXPLANATION

ALTITUDE OF LAND SURFACE, IN FEET ABOVE SEA LEVEL

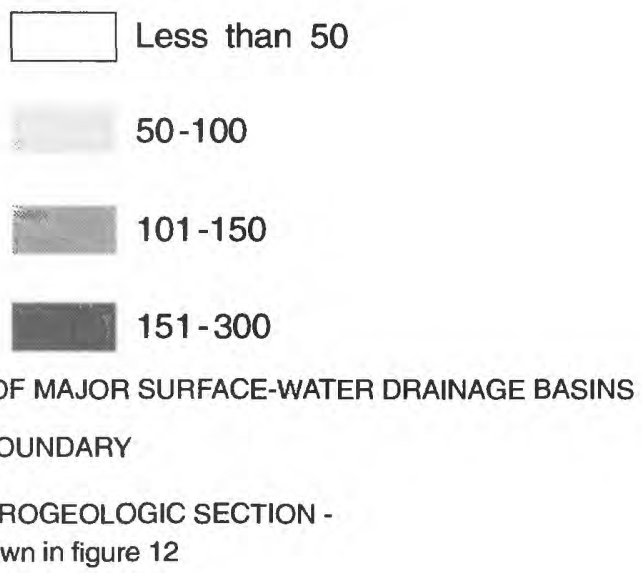

Figure 3. Generalized topography and major surface-water drainage basins. 
The Kissimmee River basin drains about one-third of the study area, including the southwest and south-central parts of Orange County. Headwater streams of the Kissimmee River include the southward-flowing Reedy Creek and Shingle Creek. Drainage within this basin is poorly developed. The Coastal basin drains about 3 percent of the study area in parts of northeast Brevard and southeast Volusia Counties. The small streams that drain the Coastal basin have relatively small drainage subbasins. Water from the coastal area drains into lagoons which connect to the Atlantic Ocean through inlets.

\section{HYDROGEOLOGIC CONDITIONS}

The hydrogeologic framework of the study area includes the surficial aquifer system, the intermediate confining unit, and the Floridan aquifer system. The Floridan aquifer system is further subdivided into the Upper Floridan aquifer, the middle semiconfining unit, and the Lower Floridan aquifer. The relation between the geologic units described in this section and the Floridan aquifer system is shown in figure 4.

\section{Surficial Aquifer System}

The unconfined surficial aquifer system is the uppermost water-bearing unit in the study area. The system consists of fine-to-medium-grained quartz sand with varying amounts of silt, clay, and crushed shell and ranges in age from Pliocene to Recent. Thickness of the surficial aquifer system is highly variable, ranging from less than $10 \mathrm{ft}$ in areas of the St. Johns River basin to greater than $150 \mathrm{ft}$ along the high ridge areas of west Orange and east Lake Counties. With increasing depth, the surficial aquifer system sediments generally grade into less permeable clayey or silty sands that, in some areas, compose the upper part of the intermediate confining unit and elsewhere directly confine the Floridan aquifer system. The base of the surficial aquifer system is approximately $40 \mathrm{ft}$ below land surface in much of Orange County (Lichtler, 1968, p. 83) and ranges from 20 to $60 \mathrm{ft}$ below land surface in most of Seminole County (Tibbals, 1977, p. 2).

The surficial aquifer system is recharged by rainfall, irrigation, septic tank effluent and, in parts of southwest Orange County, by land application of reclaimed water. Water from the underlying Floridan aquifer system can also leak upward through the intermediate confining unit to recharge the surficial aquifer system in areas where the water table is lower than the potentiometric surface of the Upper Floridan aquifer. Water is discharged from the surficial aquifer system by seepage to lakes, streams, and ditches; by evapotranspiration where the water table is near land surface; by pumpage; and by downward leakage to the Floridan aquifer system in areas where the potentiometric surface of the Upper Floridan aquifer is lower than the water table. The surficial aquifer system is rarely used as a source of potable water because well yields are low and the water commonly contains high concentrations of dissolved iron and can be highly colored.

\section{Intermediate Confining Unit}

The intermediate confining unit separates the surficial and Floridan aquifer systems throughout the study area. The unit includes all sediment beds of late-to-middle Miocene age (Hawthorn Group), and locally, low permeability beds of early Pliocene age (Miller, 1986, p. 43). Sediments include interbedded sands, calcareous silts and clays, shell, and phosphatic limestone and dolomite. The thickness of the intermediate confining unit ranges from less than $50 \mathrm{ft}$ across much of Seminole, southwest Volusia, and east Lake Counties to greater than $250 \mathrm{ft}$ in southeast Orange County (fig. 5). In east Lake and west Orange Counties, where the unit is locally breached by numerous sinkholes, thicknesses may range from $0 \mathrm{ft}$ at a sinkhole to greater than $100 \mathrm{ft}$ within a few tens of feet from the depression. In southwest Seminole County, the thickness of the unit ranges from 80 to $150 \mathrm{ft}$ (Anderson and Hughes, 1975, p. 5), thinning to about $20 \mathrm{ft}$ near the city of Lake Mary. Deposits in the east part of Seminole County near Geneva are reported to range from 20 to $60 \mathrm{ft}$ in thickness (Phelps and Rohrer, 1987 , p. 8). The Hawthorn Group is absent in northeast Seminole and southwest Volusia Counties and the surficial and Floridan aquifer systems are separated by deposits of fine sand, shells, and calcareous silty clays present at the base of the surficial aquifer system (Tibbals, 1977; Phelps, 1990, p. 17). In the southwest part of the study area, in Polk County, unit thicknesses range from 6 to $20 \mathrm{ft}$ (Grubb, 1978; Johnson, 1979). The thickness of the intermediate confining unit at any particular site may differ markedly from the generalized ranges shown in figure 5 because of local 


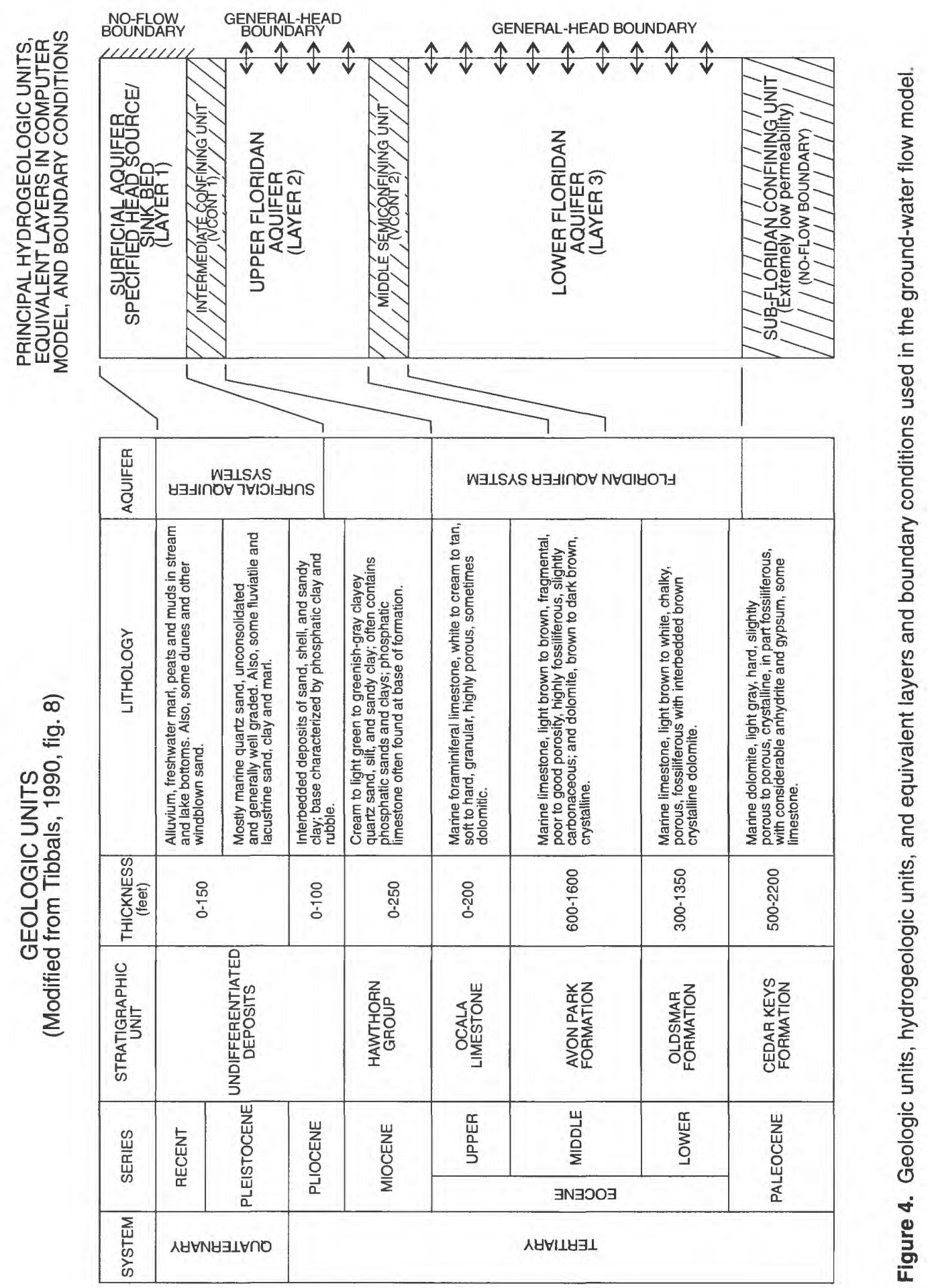




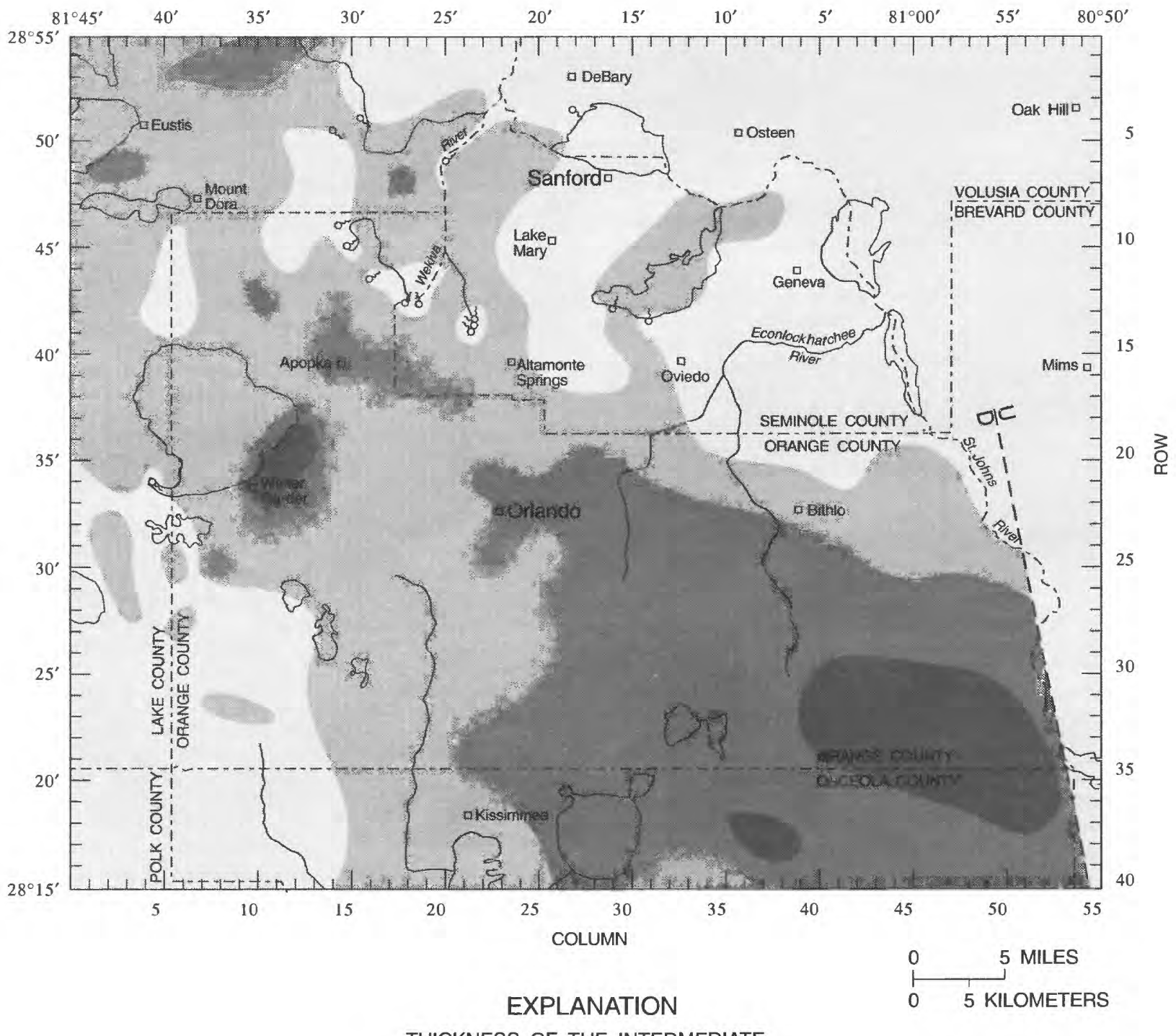

THICKNESS OF THE INTERMEDIATE

CONFINING UNIT, IN FEET

Less than 50

$50-100$

$101-150$

$151-250$

- - - $\overline{\mathrm{D}}^{-}-$- POSSIBLE FAULT--Vertical or nearly so.

$U$, upthrown side; $D$, downthrown side.

Figure 5. Generalized thickness of the intermediate confining unit (compiled from Boniol (1994); Brown (1962); Grubb and Rutledge (1979); Lichtler (1968); McGurk, Bond, and Mehan (1989); Phelps and Rohrer (1987); Schiner (1993); and Tibbals (1976)). 
irregularities caused by erosion and by the occurrence of collapse features in the underlying limestone.

Hydraulic conductivity of the intermediate confining unit is highly variable. Localized beds of sand, shell, and gravel present in the upper part of the formation in east Orange County yield substantial quantities of water to wells. Much lower hydraulic conductivities characterize the clays present in the Hawthorn Group. Laboratory testing of selected clay cores yielded hydraulic conductivity values that ranged from about $8 \times 10^{-7}$ to $2 \times 10^{-2} \mathrm{ft} / \mathrm{d}$ (Miller, 1986 , p. 43). Localized beds of basal Hawthorn limestone that are in direct hydraulic contact with the Upper Floridan aquifer in the north and west parts of the study area have been considered by some previous investigators to mark the top of the Floridan aquifer system. However, because the hydraulic conductivity of the Hawthorn limestone is at least an order of magnitude less than that of the underlying Floridan limestone, and because Hawthorn limestone beds occur only locally, they are not considered to be part of the Floridan aquifer system (Miller, 1986, p. 43). This report follows the conventions of Miller (1986).

Leakance of the intermediate confining unit reported from aquifer tests range from $1 \times 10^{-4} / \mathrm{d}$ in east Orange County to about $2 \times 10^{-2} / \mathrm{d}$ in northeast Polk County (Tibbals, $1976 ; 1982$ ), and from $3 \times 10^{-4} / \mathrm{d}$ to $1 \times 10^{-2} / \mathrm{d}$ in Seminole County (Szell, 1993). Leakance values computed from aquifer tests generally are higher than model-calibrated RASA values because field-derived values are often calculated from an analytical solution (Hantush and Jacob, 1955) that assumes leakage to the pumped well is derived solely from the surficial aquifer system through the intermediate confining unit. In actuality, leakage from the Lower Floridan aquifer through the middle semiconfining unit also contributes water to the pumped wells. As a result, values derived from aquifer tests represent the combined or resultant leakances of both the intermediate confining and middle semiconfining units, providing an upper bound for model calibration purposes. Field-derived values also can be used to distinguish between general areas of relatively high and low leakance.

\section{Floridan Aquifer System}

The Floridan aquifer system is composed of a sequence of highly permeable, Tertiary limestone and dolomitic limestone that thickens from about $2,000 \mathrm{ft}$ in the northwest part of the study area to more than $2,600 \mathrm{ft}$ near the southeast part of the study area (Tibbals, 1990, fig. 10). From bottom to top, the geologic units of the aquifer system are of Eocene age and include the Oldsmar Formation, the Avon Park Formation, and the Ocala Limestone (fig. 4). The base of the system is marked by the first occurrence of relatively impermeable, vertically persistent beds of anhydrite generally found in the upper third of the Paleocene-age Cedar Keys Formation.

The Floridan aquifer system consists of two major permeable zones separated by a less permeable zone of highly variable water-transmitting characteristics. Water-level and water-quality data and flow-meter logs indicate that this less permeable zone acts as a semiconfining unit that hydraulically separates the more permeable zones above and below it (Miller, 1986, p. 56). Based on this information, the Floridan aquifer system has been divided into the Upper Floridan aquifer, the middle semiconfining unit, and the Lower Floridan aquifer (Tibbals, 1981; Miller, 1986).

\section{Lithology and Structure}

The Upper Floridan aquifer consists of the Ocala Limestone and the dolomite and dolomitic limestones of the upper one-third of the Avon Park Formation. The Ocala limestone generally is soft, porous, white-to-cream colored, and contains numerous caverns, fissures, and other features of secondary porosity. The Ocala Limestone has been removed by erosion in south-central Orange and north-central Osceola Counties and in a small area of southwest Seminole County. The top of the Upper Floridan aquifer in these areas is defined by the dolomitic limestones of the Avon Park Formation. The top of the aquifer generally dips from northwest-to-southeast across the study area, with altitudes ranging from 0 to $50 \mathrm{ft}$ above sea level in Lake County to more than $300 \mathrm{ft}$ below sea level in southeast Orange and northeast Osceola Counties (fig. 6). The contours shown in figure 6 are for generalized conditions and were compiled from work by Lichtler and others (1968), Knochenmus (1976), Tibbals and Frazee (1976), Rutledge (1985), Schiner (1993), and Boniol (1994). The altitude of the top of the Upper Floridan aquifer at any particular site may differ from that indicated in figure 6 because of local irregularities caused by erosion and solution of the limestone or by collapse of sinkholes.

Wide variations in the altitude of the top of the Upper Floridan aquifer near the St. Johns River have 


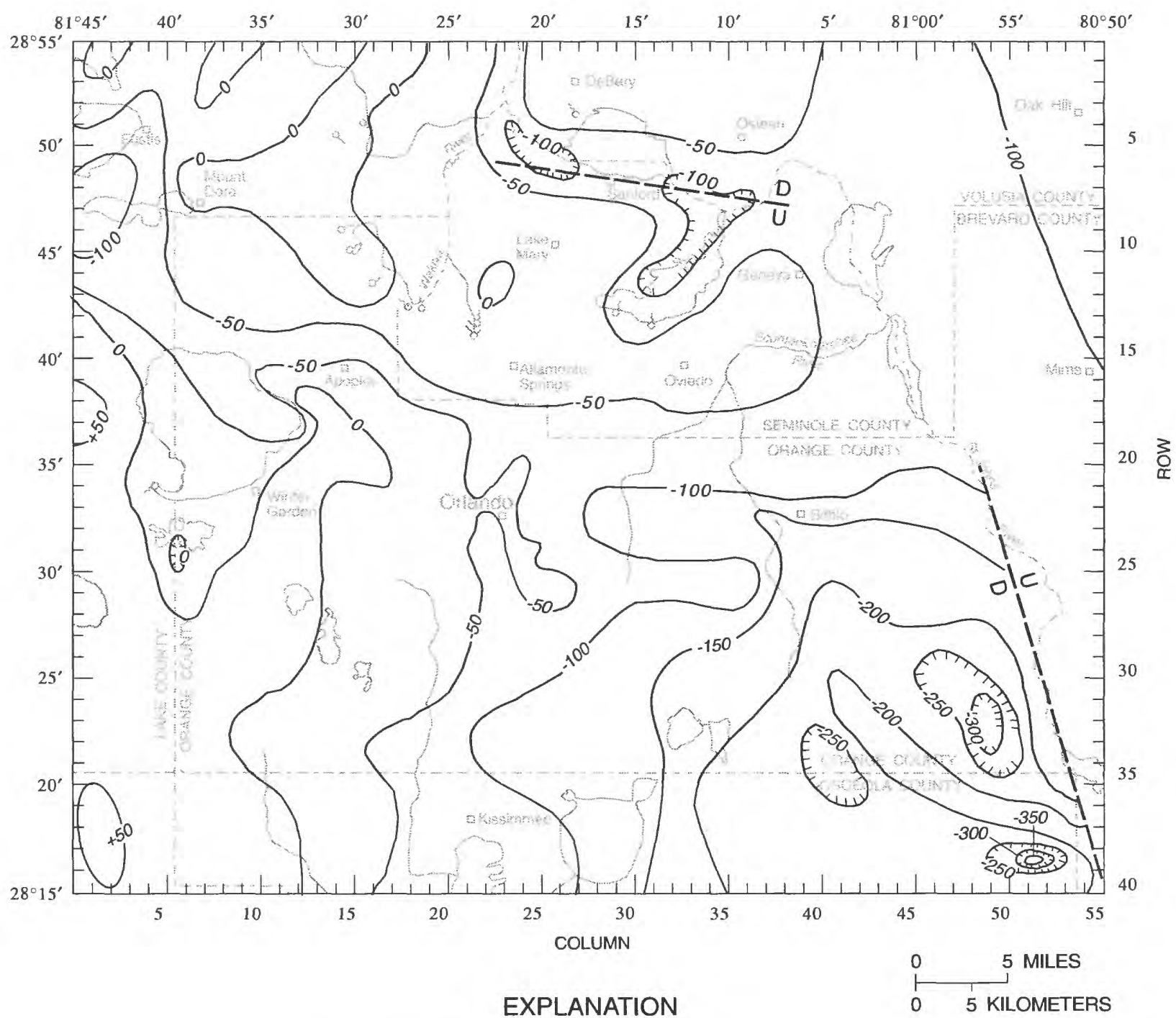

EXPLANATION

STRUCTURE CONTOUR - Shows altitude of the top of the Upper Floridan aquifer. Hachures indicate depression. Contour interval 50 feet. Datum is sea level

- $-\frac{U}{D}-$ POSSIBLE FAULT -- Vertical or nearly so. U, upthrown side; D, downthrown side

Figure 6. Altitude of the top of the Upper Floridan aquifer (compiled from Boniol (1994); Knochenmus (1976); Lichtler (1968); Rutledge (1984); Schiner (1993); and Tibbals (1976)).

been attributed by some investigators to a system of faults aligned with the river. The offset course of the St. Johns River northwest of Lake Harney could be indicative of subsurface faulting (Pirkle, 1971). Two inferred faults mapped by previous investigators and shown in figure 6 include an east-west oriented fault through north Seminole County (Barraclough, 1962) and a north-south oriented fault through west Brevard County (Brown and others, 1962). The inferred fault in west Brevard County would explain the unusually large difference (about $200 \mathrm{ft}$ ) in the altitude of the top of the Upper Floridan aquifer over a relatively short ( $2 \mathrm{mi}$ ) distance. Other investigators believe the inferred faults are based on sparse, limited well data and that offsets may be due to steeper-than-average dipping of the rock surface. Spechler (1994) showed that structures thought to be faults in the Jacksonville area could also be collapse features of a regional scale.

The middle semiconfining unit consists of less permeable, soft micritic limestone and dense dolomitic 
limestone in the middle one-third of the Avon Park Formation (fig. 4). The unit underlies the entire study area and thickens from about $200 \mathrm{ft}$ in Lake County to about $800 \mathrm{ft}$ in southeast Orange and northeast Osceola Counties (Tibbals, 1990, fig. 13). The lithologic character of the limestone and dolomite varies considerably, both with depth and areally across the unit. Lichtler (1972, p. 13) noted the presence of interconnected solution channels in this unit, but added that in areas where the dolomitic layers do not contain solution channels or fractures, they probably inhibit vertical movement of water.

The Lower Floridan aquifer includes the bottom one-third to one-half of the Avon Park Formation and all of the Oldsmar Formation. Aquifer lithology is limestone and fractured dolomite. The top of the Lower Floridan aquifer dips from northwest-to-southeast across the study area, with altitudes from about $600 \mathrm{ft}$ to more than $1,200 \mathrm{ft}$ below sea level (Miller, 1986). Thickness of the aquifer averages about $1,500 \mathrm{ft}$ across the study area.

\section{Aquifer Recharge and Discharge}

The Upper Floridan aquifer is recharged by downward leakage from the surficial aquifer system; by lateral inflow across the study area boundaries; and, for developed conditions, through drainage wells in the Orlando area and from the land application of reclaimed water. Estimated rates of recharge to the Upper Floridan aquifer from the surficial aquifer system range from less than $3 \mathrm{in} / \mathrm{yr}$ (low-rate recharge areas) to greater than $10 \mathrm{in} / \mathrm{yr}$ (high-rate recharge areas) (fig. 7). High-rate recharge areas in west Orange, east Lake, and southwest Volusia Counties are characterized by karstic sand ridges with relatively deep water tables. Rainfall in these recharge areas infiltrates rapidly into the thick, permeable surficial sands, reducing losses from surface runoff and evapotranspiration. The highest rates of recharge occur locally within closed sinkhole basins where the intermediate confining unit is breached and surface runoff is negligible. High recharge rates in west Seminole County can be attributed to a relatively thin intermediate confining unit. Low-rate recharge areas include the topographically low areas of the Kissimmee River basin in south-central Orange and north Osceola Counties, and the Coastal basin of east Volusia and north Brevard Counties. The water table in these areas typically is within a few feet of land surface, limiting storage capacity in the unsaturated zone and enhancing evapotranspiration and surface runoff.

The generalized areas of recharge and discharge shown in figure 7 are composited from separate county-wide maps constructed by previous investigators from basin-wide water budgets, soil-drainage properties, and other hydrogeologic data. The actual recharge rate at any particular site may vary considerably from that shown in figure 7. However, this generalized map distinguishes between broad areas of varying recharge potential.

Anthropogenic structural features also provide recharge to the Floridan aquifer system. Numerous drainage wells constructed in and around the city of Orlando between the early 1900's and mid-1960's convey water directly into the confined Floridan aquifer system. The USGS has inventoried 377 of these wells (Kimrey, 1978), half of which were designed to dispose of stormwater runoff in areas where natural drainage is poorly developed. A third of the wells were constructed for lake-level control, and the remainder were constructed to dispose of various types of industrial and municipal wastewater.

Recharge to the aquifer from these wells has been estimated at about $30 \mathrm{Mgal} / \mathrm{d}$ (Tibbals, 1990, p. 28), but may be considerably more or less.

Recharge rates through individual drainage wells are largely undocumented and vary with the size of the respective drainage basin, the amounts of impervious area within the basin, soil conditions, and the condition of the well. Drainage-basin areas and associated recharge rates are larger for lake-level control wells that continuously receive water (such as those at Lake Underhill and Lake Killarney (fig. 2)) than for wells that dispose of stormwater runoff during discrete rainfall events. Recharge rates measured at the Lake Underhill well in 1988 averaged about $2.1 \mathrm{Mgal} / \mathrm{d}$ (Bradner, 1991); rates measured at the Lake Killarney well in 1993 averaged about 2.5 Mgal/d (Anne Bradner, USGS, oral commun., September 1994). Past inspections indicate that some of the wells have either been plugged with debris or destroyed and no longer recharge the aquifer (Kimrey, 1978; Bradner, 1991; and Taylor, 1993).

Reclaimed water from municipal treatment facilities operated by the city of Orlando and by Orange County is disposed of by land application to rapid-infiltration basins (RIBS) and by citrus irrigation in southwest Orange and east Lake Counties. In 1988, about $12.5 \mathrm{Mgal} / \mathrm{d}$ of reclaimed water was used to irri- 


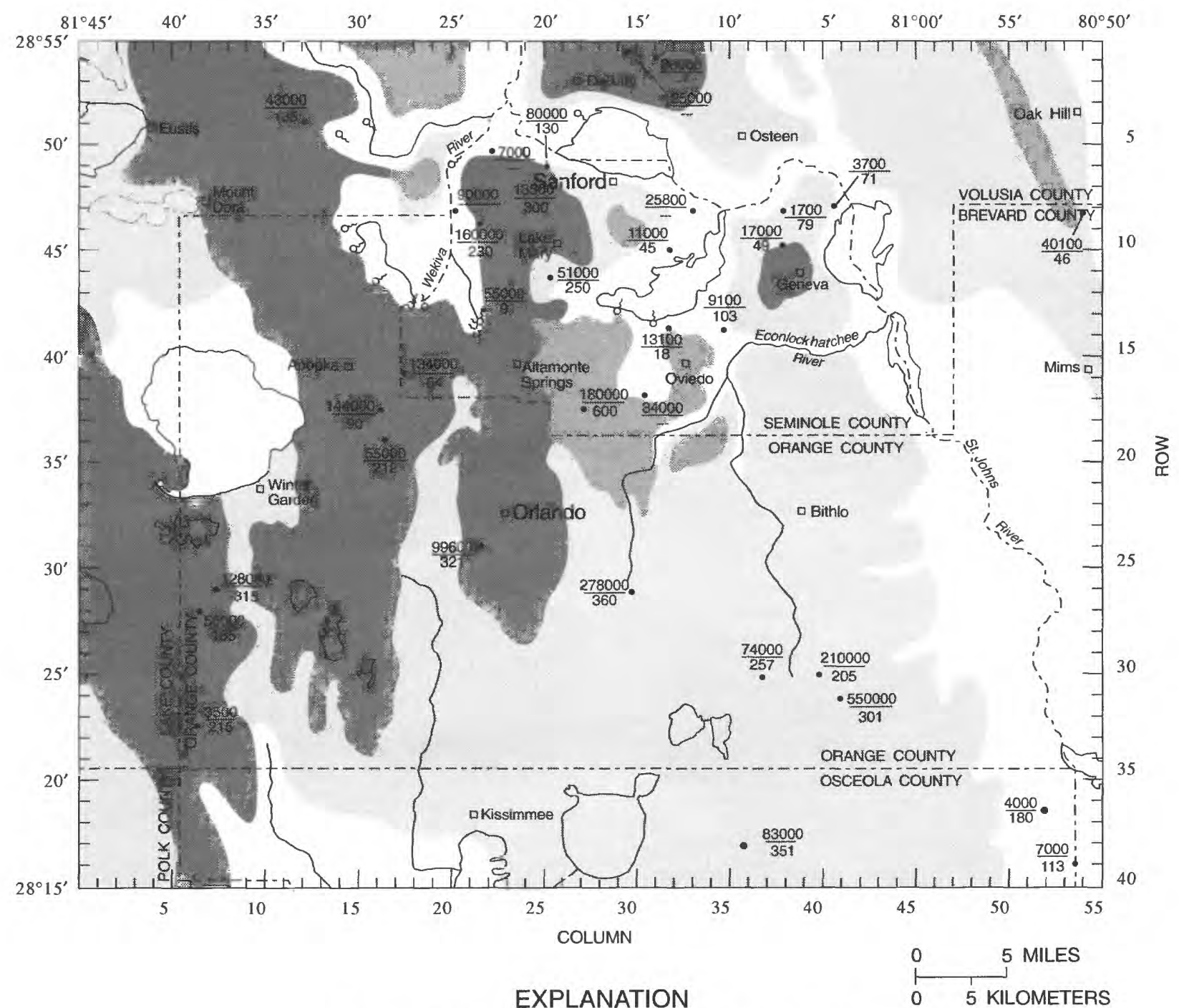

DISTRIBUTION OF RECHARGE TO AND DISCHARGE
FROM THE UPPER FLORIDAN AQUIFER, IN INCHES PER YEAR

less than 0 (area of discharge)

0-3 (low recharge)

3-10 (moderate recharge)

greater than 10 (high recharge)

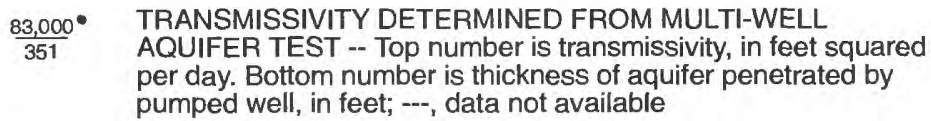

Figure 7. Generalized distribution of recharge to and discharge from the Upper Floridan aquifer and results of selected aquifer tests (compiled from Frazee (1980); Knochenmus (1976); Lichtler (1968; 1972); Szell (1993); Tibbals (1977); and Vecchioli and others (1990)). 
gate 2,000 acres of citrus, $9.5 \mathrm{Mgal} / \mathrm{d}$ was applied to RIBS, and $1 \mathrm{Mgal} / \mathrm{d}$ was applied to alternate application (sinkhole) sites (Metcalf \& Eddy, Inc., written commun., 1993). Most of the reclaimed water eventually recharges the Upper Floridan aquifer because no streams exist to transport water away from the disposal area and because flow in the surficial aquifer system is intercepted by numerous sinkholes that act as vertical conduits to the Upper Floridan aquifer.

Natural discharge from the Upper Floridan aquifer occurs primarily by spring flow. During 1988, 15 springs within the study area collectively discharged about $306 \mathrm{ft}^{3} / \mathrm{s}$ of water from the aquifer, slightly less than the $356 \mathrm{ft}^{3} / \mathrm{s}$ of water pumped from the aquifer by wells. Discharge rates measured at individual springs, which are subject to errors of up to 10 percent or greater, ranged from about $69 \mathrm{ft}^{3} / \mathrm{s}$ at Wekiva Springs to about $1 \mathrm{ft}^{3} / \mathrm{s}$ at Lake Jesup, Sulphur, and Witherington Springs (table 1). The discharge rates shown in table 1 for Wekiva, Rock, Sanlando, Palm, Starbuck, and Miami Springs were averaged from measurements made in May and September 1988 , months that generally provide seasonal low and high values, respectively. Discharge rates shown for Seminole and Messant Springs represent May 1988 measured values only (September 1988 measurements were not made at these springs); discharge rates indicated for Apopka, Island, Gemini, Witherington, Clifton, Sulphur, and Lake Jesup Springs were estimated from measurements made prior to or after 1988 because no measurements were made at these springs in 1988. Differences between actual 1988 discharge rates and those indicated for the smaller springs (less than $2 \mathrm{ft}^{3} / \mathrm{s}$ ) can be neglected because their collective discharge represents less than 3 percent of the total and these springs exert little influence on the ground-water flow system.

Flow at undocumented springs also may account for appreciable quantities of water discharged from the Upper Floridan aquifer. One area where undocumented spring flow likely occurs is along the St. Johns River from just below Lake Harney downstream to the

Table 1. Discharge from selected Upper Floridan aquifer springs in the Orlando metropolitan area for 1988 and predevelopment steady-state conditions

[R, spring locations published by Rosenau and Faulkner (1977); U, spring and flowing well locations estimated from U.S. Geological Survey (USGS) quadrangle maps; T, spring location published by Tibbals (1990); RT, revised from Tibbals (1990), based on inspection of additional or more current data; C, estimate from data collected during current study and not included in Tibbals (1990) report; spring discharge is in cubic feet per second; --, not applicable]

\begin{tabular}{|c|c|c|c|c|c|c|c|c|}
\hline \multirow{2}{*}{$\begin{array}{c}\text { Name } \\
\text { of } \\
\text { spring }\end{array}$} & \multicolumn{2}{|c|}{ Spring location } & \multirow{2}{*}{$\begin{array}{l}\text { Spring } \\
\text { loca- } \\
\text { tion } \\
\text { source }\end{array}$} & \multicolumn{2}{|c|}{ Model } & \multirow{2}{*}{$\begin{array}{c}1988 \\
\text { average } \\
\text { discharge }^{a}\end{array}$} & \multirow{2}{*}{$\begin{array}{c}\text { Estimated } \\
\text { predevelop- } \\
\text { ment } \\
\text { discharge }\end{array}$} & \multirow{2}{*}{$\begin{array}{l}\text { Source of } \\
\text { estimates }\end{array}$} \\
\hline & Latitude & Longitude & & Row & Column & & & \\
\hline Wekiva & 284243 & 0812736 & $\mathbf{R}$ & 13 & 18 & 69 & 80 & RT \\
\hline Apopka & 283400 & 0814051 & $\mathbf{R}$ & 21 & 5 & 61 & 70 & RT \\
\hline Rock & 284520 & 0812958 & $\mathbf{R}$ & 10 & 15 & 58 & 70 & $\mathrm{~T}$ \\
\hline Sanlando & 284119 & 0812344 & $\mathbf{R}$ & 14 & 22 & 20 & -- & $\mathrm{T}$ \\
\hline Palm & 284127 & 0812334 & $\mathbf{R}$ & 14 & 22 & 6 & $50^{b}$ & $\mathrm{~T}$ \\
\hline Starbuck & 284148 & 0812328 & $\mathbf{R}$ & 14 & 22 & 15 & -- & $\mathrm{T}$ \\
\hline Seminole & 285044 & 0813122 & $\mathbf{R}$ & 5 & 14 & 39 & 40 & RT \\
\hline Messant & 285121 & 0812956 & $\mathbf{R}$ & 4 & 16 & 14 & 20 & $\mathrm{~T}$ \\
\hline Island & 284922 & 0812503 & $\mathrm{~T}$ & 6 & 20 & 6 & 10 & RT \\
\hline Gemini & 285144 & 0811839 & $\mathbf{R}$ & 4 & 27 & 8 & 10 & $\mathrm{~T}$ \\
\hline Miami & 284236 & 0812634 & $\mathbf{R}$ & 13 & 19 & 5 & 6 & RT \\
\hline Witherington & 284353 & 0812922 & $\mathbf{R}$ & 12 & 16 & 1 & 2 & RT \\
\hline Clifton & 284156 & 0811414 & $\mathrm{R}$ & 14 & 31 & 2 & 2 & $\mathbf{T}$ \\
\hline Sulphur & 284610 & 0813035 & $\mathbf{U}$ & 9 & 15 & 1 & 2 & $\mathrm{C}$ \\
\hline Lake Jesup & 284236 & 0811605 & $\mathbf{R}$ & 13 & 29 & 1 & 1 & $\mathrm{~T}$ \\
\hline TOTAL: & & & & & & 306 & $360^{c}$ & \\
\hline
\end{tabular}

${ }^{a}$ Spring-discharge measurements typically are subject to \pm 10 percent error, except for submerged Apopka and Island Springs, which are subject to measurement errors of 25 percent or greater.

${ }^{\mathrm{b}}$ Collective total for Sanlando, Palm, and Starbuck Springs.

${ }^{\mathrm{c}}$ Rounded to two significant figures. 
Wekiva River. The intermediate confining unit in this area is relatively thin (less than $50 \mathrm{ft}$ ). Barraclough (1962, p. 35) described two areas, one near Lake Jesup and one near the Wekiva River, where relatively shallow excavations produced small spring flow. Tibbals (1981, p. 17) simulated $54 \mathrm{ft}^{3} / \mathrm{s}$ of Upper Floridan aquifer discharge from beneath the St. Johns River between Lakes Harney and Jesup. The Upper Floridan aquifer probably does not discharge much water to the St. Johns River between the confluence of the Econlockhatchee River south to Lake Poinsett, where streamflow measurements indicate little or no increase in baseflow (Tibbals, 1990, p. 29).

Abandoned flowing wells, constructed during the early 1900 's to the 1970's to irrigate vegetable crops, also discharge water from the Upper Floridan aquifer. As of 1990 , nearly 500 such wells were located in the study area by the SJRWMD (Steele, 1991). The majority of these wells are in Seminole County, just north and southeast of Lake Jesup. The total discharge from these wells is unknown because flow has been measured from only a relatively small number of wells. However, a rough estimate of $12 \mathrm{Mgal} / \mathrm{d}$ was made by extrapolating flows measured at wells of known diameter to unmeasured wells of the same diameter.

\section{Hydraulic Characteristics}

The transmissivity of an aquifer characterizes its ability to transmit water and is defined as "the rate of flow under unit hydraulic gradient through a cross section of unit width over the whole saturated thickness of the aquifer" (Bear, 1979). Transmissivity is calculated as the product of the aquifer's horizontal hydraulic conductivity and its saturated thickness.

Transmissivity of the Floridan aquifer system reported from aquifer tests varies widely across the study area (fig. 7). Variations from one test to another can be attributed to the heterogeneity of the system and to differences in well-penetration intervals and depths. In northwest Seminole County, transmissivity values of $13,500 \mathrm{ft}^{2} / \mathrm{d}$ and $160,000 \mathrm{ft}^{2} / \mathrm{d}$ were reported from two tests conducted relatively close to one another in the Upper Floridan aquifer. The wells used in these tests penetrated similar depths of the aquifer. Tests conducted in three wells that penetrated similar intervals of the Upper Floridan aquifer at the Cocoa well field yielded transmissivities of $74,000 \mathrm{ft}^{2} / \mathrm{d}, 210,000 \mathrm{ft}^{2} / \mathrm{d}$, and $510,000 \mathrm{ft}^{2} / \mathrm{d}$. The heterogeneous nature of the aquifer limits the extrapolation of field-derived hydrau- lic characteristic data to accurately estimate the spatial distribution of transmissivity beyond the field-tested areas. Moreover, field-derived values may underestimate actual transmissivity because wells used in aquifer tests seldom penetrate the full thickness of the aquifer. However, these tests do serve as a lower limit for flow-model calibration.

Specific-capacity and normalized well-yield data collected in Seminole County by Tibbals (1977) were used to distinguish between areas of relatively high, moderate, and low transmissivity within the Upper Floridan aquifer. Specific capacity is calculated by dividing the discharge rate at a pumping well by the drawdown measured in the well. Normalized well yield is equal to the well discharge divided by the length of the open hole. Specific capacities and well yields are lower in discharge areas near the St. Johns River and adjoining lakes than in areas further southwest, away from the St. Johns River. The highest specific capacities and well yields were mapped in high-rate recharge areas of west Seminole County from Altamonte Springs northeast to the Seminole-Lake County line.

Aquifer-test data for the Lower Floridan aquifer are sparse. However, three tests performed in Orange County yielded relatively high transmissivities. Values of 574,000 and $668,000 \mathrm{ft}^{2} / \mathrm{d}$ were reported from tests at two water-supply facilities operated by the city of Orlando (Lichtler, 1968). A third test conducted $2 \mathrm{mi}$ south of Apopka yielded a value of $632,000 \mathrm{ft}^{2} / \mathrm{d}$ (Post, Buckley, Schuh, and Jernigan, Inc., 1989).

Few data are available to quantify the hydraulic properties of the middle semiconfining unit. A multi-zoned aquifer test conducted at the Bull Creek Wildlife Management Area in north Osceola County, just outside the boundary of the study area, was used to estimate a range of effective vertical hydraulic conductivity values for a part of this unit described as having relatively low porosity and permeability. Calculated test values ranged from $5 \times 10^{-3}$ to $2 \mathrm{ft} / \mathrm{d}$ (Post, Buckley, Schuh and Jernigan, Inc., 1990). Leakance values derived from this test range from $1 \times 10^{-5} / \mathrm{d}$ to $1 \times 10^{-3} / \mathrm{d}$, bracketing the value of $5 \times 10^{-5} / \mathrm{d}$ used in the RASA model. Recent USGS aquifer tests conducted at the Cocoa well field indicate that the middle semiconfining unit can be highly anisotropic (Phelps and Schiffer, 1996). The vertical hydraulic conductivity of a 6 - $\mathrm{ft}$ section of the unit was estimated to be no greater than $5 \times 10^{-2} \mathrm{ft} / \mathrm{d}$, whereas the horizontal hydraulic conductivity was estimated at $20 \mathrm{ft} / \mathrm{d}$. 
Storage coefficients calculated from aquifer tests conducted in both the Upper and Lower Floridan aquifers range from $1 \times 10^{-3}$ to $1 \times 10^{-4}$, typical of confined conditions. The storage coefficient is a measure of the volume of water released by elastic compression of the aquifer and by expansion of water as a result of declining heads. A theoretical lower limit for the storage coefficient can be made by assuming that the aquifer matrix is incompressible and the storage coefficient is attributed soley to the compressibility of water. The equation used to calculate this lower limit is taken from Lohman (1972, eq 20) as:

$$
S=\theta \gamma b / E_{w},
$$

where

$S$ is the storage coefficient,

$\theta$ is the volumetric aquifer porosity, $\gamma$ is the specific weight of water $\left(62.4 \mathrm{lb} / \mathrm{ft}^{3}\right)$,

$b$ is the aquifer thickness ( $\mathrm{ft}$ ), and

$E_{w}$ is the bulk modulus of elasticity of water $\left(4.5 \times 10^{7} \mathrm{lb} / \mathrm{ft}^{2}\right)$.

Assuming a porosity of 0.2 and a thickness of $300 \mathrm{ft}$ for the Upper Floridan aquifer, the storage coefficient due to the compressibility of water is $8 \times 10^{-5}$. Similarly, with an assumed porosity of 0.2 and a thickness of $1,000 \mathrm{ft}$, the storage coefficient due to the compressibility of water for the Lower Floridan aquifer is $3 \times 10^{-4}$. Higher values calculated from aquifer tests can be attributed to the compressibility of the aquifer matrix and from storage effects not considered in the test analysis.

\section{Water Levels and Effects of Pumping}

Prior to ground-water development, water levels in the Floridan aquifer system responded seasonally to variations in rainfall. Average long-term, annual predevelopment water levels probably were in a dynamic equilibrium; that is, water-level fluctuations were small with respect to total aquifer thickness and the relative configuration of the potentiometric surface was maintained through seasonal or longer cycles of fluctuations.

The estimated potentiometric surface of the Upper Floridan aquifer prior to extensive ground-water development is shown in figure 8. This map was adapted from a multi-state potentiometric surface map of the entire Tertiary limestone aquifer
(Johnston and others, 1980) and is a composite of many other maps including recent potentiometric surface maps in areas only marginally affected by pumping, and older maps or modifications of older maps of areas where ground-water development is extensive. Potentiometric contours were estimated largely from water-level data collected in the 1930's by Stringfield (1936). Water levels measured in 45 of these wells are shown in figure 8.

Ground water in the Upper Floridan aquifer moves regionally in a southwest-to-northeast direction across the study area, from altitudes of more than $120 \mathrm{ft}$ in north Polk County to less than $10 \mathrm{ft}$ in east Seminole County. Depressed contours around Lake Harney in east Seminole County indicate significant Upper Floridan aquifer discharge beneath the St. Johns River in this area. Upper Floridan aquifer discharge also occurs laterally across the northcentral boundary in Volusia County, along the east boundary into Brevard County, and across the northwest part of the study-area boundary in Lake County. Lateral recharge to the Upper Floridan aquifer occurs along the west boundary of the study area in Lake County and from the north in Volusia County, northeast of Lake Monroe.

Prior to extensive ground-water development, discharge from the 15 documented Upper Floridan aquifer springs was estimated at about $360 \mathrm{ft}^{3} / \mathrm{s}$ (table 1). Predevelopment discharge rates for Rock, Sanlando, Palm, Starbuck, Messant, Gemini, Clifton, and Lake Jesup Springs were obtained from the RASA report (Tibbals, 1981, p. 16) and rounded to the nearest single significant figure to reflect the error inherent in the estimates. Discharge estimates for Wekiva, Apopka, Seminole, Island, Miami, and Witherington Springs were revised from previous RASA estimates, based on additional data and recent measurements. At Apopka Spring, for example, the RASA-estimated discharge rate of $30 \mathrm{ft}^{3} / \mathrm{s}$ was based on a single field measurement. Subsequent measurements made by the USGS indicate that about $70 \mathrm{ft}^{3} / \mathrm{s}$ may have discharged from Apopka Spring prior to development.

Extensive ground-water development of the Floridan aquifer system has affected both Upper Floridan aquifer water levels and spring discharge (fig. 9). From 1950 to 1992, pumpage from Orlando and Winter Park well fields alone increased from about 10 to about $90 \mathrm{Mgal} / \mathrm{d}$. Increased withdrawals have lowered the potentiometric surface of the Upper Floridan aqui- 

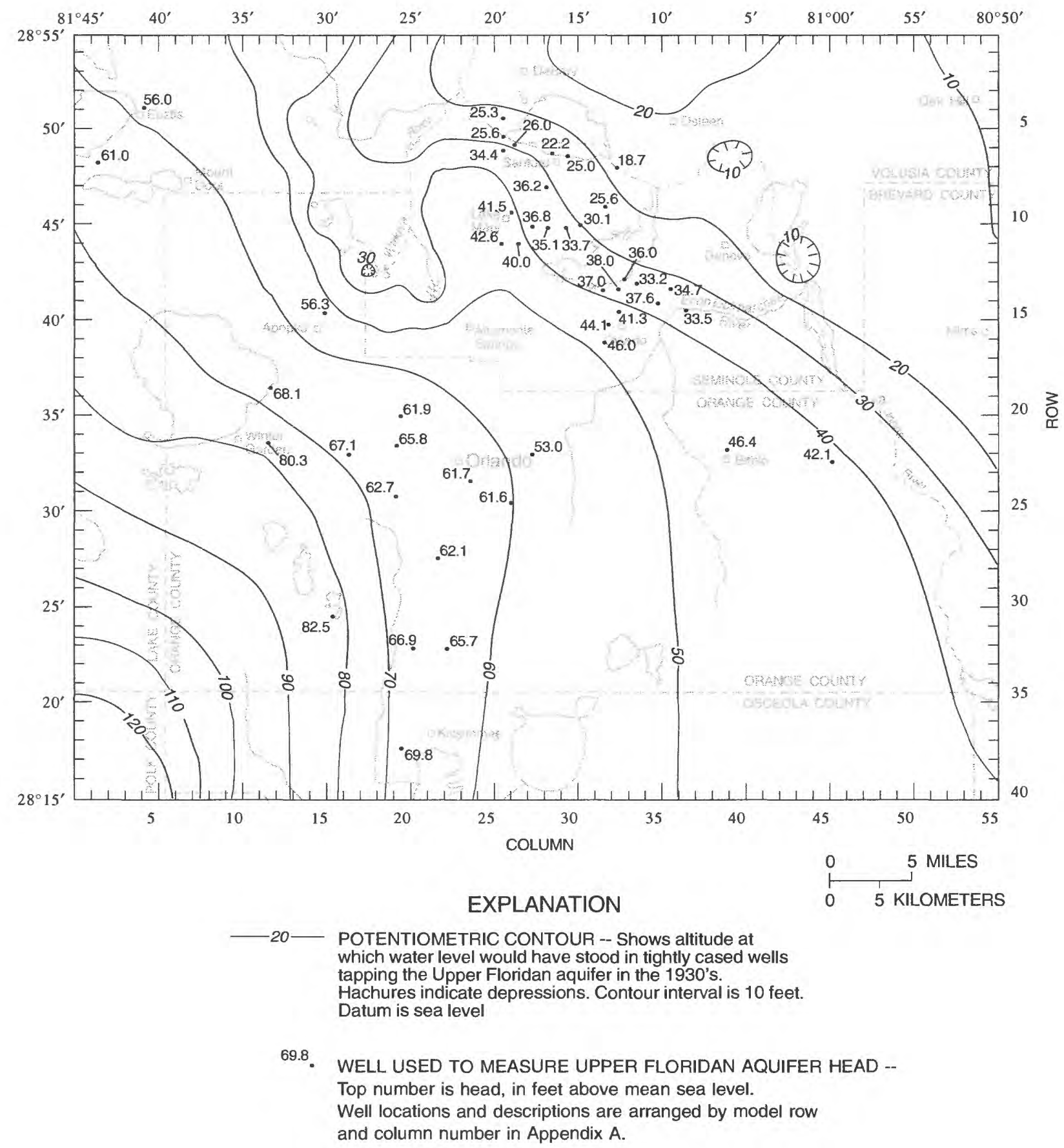

Figure 8. Potentiometric surface of the Upper Floridan aquifer prior to extensive ground-water development (adapted from Johnston, 1980) and water levels measured at selected Upper Floridan aquifer monitoring wells in the early 1930's (from Stringfield, 1936).

fer, as shown by the water-level record at monitoring well OR-47 (fig. 9), thus reducing the hydraulic gradients that move water toward the springs. As a result, discharge from Wekiva Springs has declined over the years (fig. 9), as have the discharges from the other springs. Total spring flow measured in $1988\left(306 \mathrm{ft}^{3} / \mathrm{s}\right)$ was about 15 percent less than estimated predevelopment spring flow $\left(360 \mathrm{ft}^{3} / \mathrm{s}\right)$.

The average 1988 Upper Floridan aquifer potentiometric surface and the areal distribution of water-level declines (drawdowns) that have occurred since the early 1930 's are shown in figure 10 . Pumpage 

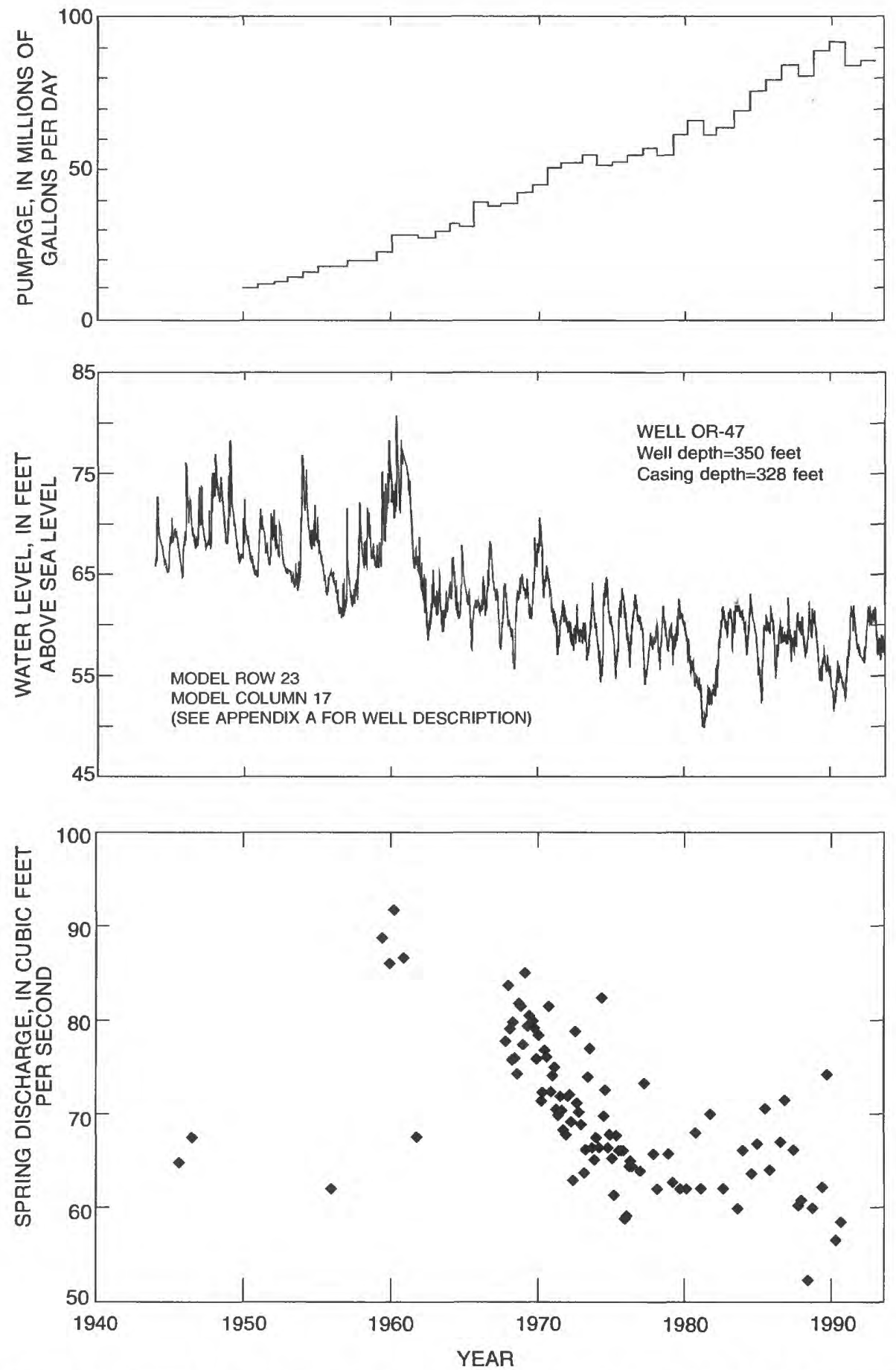

Figure 9. Pumpage from Floridan aquifer system by Orlando and Winter Park (1951-93), water levels in Upper Floridan aquifer monitoring well OR-47 (1944-93), and discharge of water from Wekiva Springs (1944-91).

from the Floridan aquifer system in 1988 was estimated at $305 \mathrm{Mgal} / \mathrm{d}$ within the study area, $230 \mathrm{Mgal} / \mathrm{d}$ of which was pumped from the Upper Floridan aquifer. Although the general configurations of the predevelopment and the average 1988 potentiometric surfaces are similar, water levels in the more highly developed parts of the study area are significantly lower than respective predevelopment levels. Drawdowns across central and east Orange County range from 10 to $20 \mathrm{ft}$, with declines of 5 to $10 \mathrm{ft}$ across Seminole County. In east Lake, south Volusia, east Seminole, north Brevard, and northeast Polk Counties, 


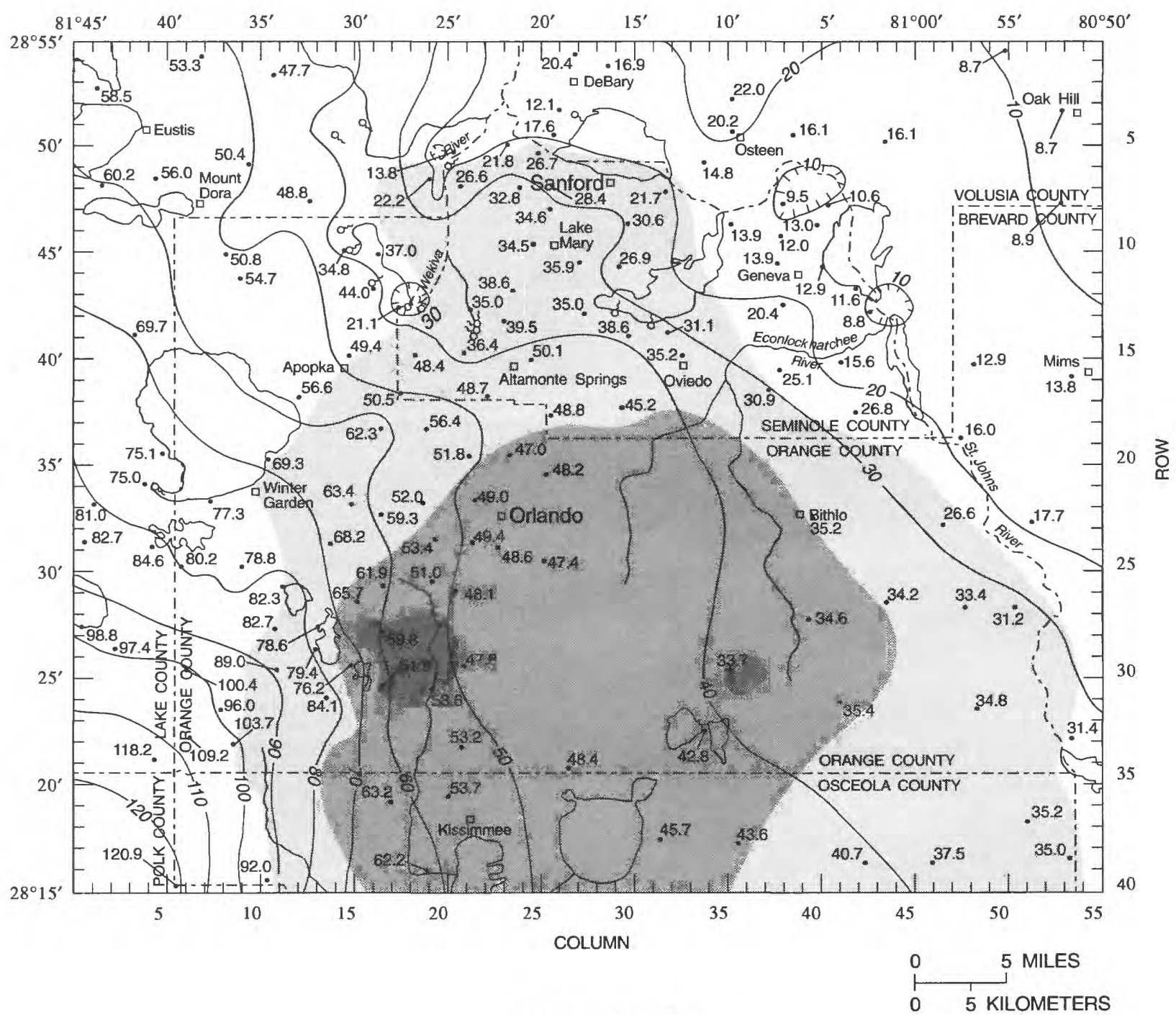

EXPLANATION

DRAWDOWN IN UPPER FLORIDAN AQUIFER

FROM PREDEVELOPMENT TO AVERAGE 1988

CONDITIONS, IN FEET
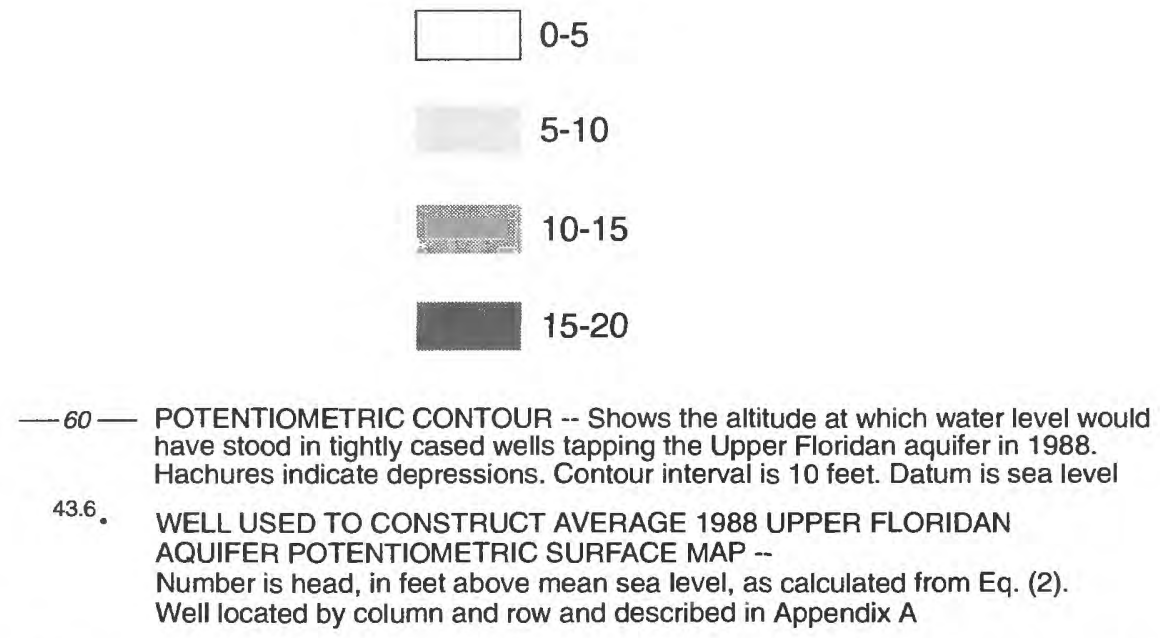

Figure 10. Average 1988 Upper Floridan aquifer potentiometric surface and drawdowns relative to predevelopment conditions. 
where relatively little development has occurred, water levels have declined by less than $5 \mathrm{ft}$.

The average potentiometric surface shown in figure 10 was constructed from water levels measured in 142 monitoring wells in May and September 1988. To evaluate average conditions for all of 1988 , a multiple linear regression was applied to define the relation between the mean annual water levels and representative May and September water levels in 14 wells equipped with continuous water-level recorders. The regression result (eq 2) was then used to calculate the average 1988 Upper Floridan aquifer head (in feet above mean sea level) at each of the 128 wells where only periodic measurements were available as:

$$
h=0.36 h_{m}+0.65 h_{s}-0.08,
$$

where

$h$ is the average 1988 Upper Floridan aquifer head (feet above sea level),

$h_{m}$ is the head measured in May 1988 (feet above sea level), and

$h_{s}$ is the head measured in September 1988 (feet above sea level).

The correlation coefficient $r^{2}$ calculated for equation 2 is 0.99 . The heads calculated by equation 2 and shown in figure 10 are probably more representative of steady-state conditions than either the May or September heads because seasonal variations in pumping and recharge affect the heads. In this case, however, the computed heads were an average of only $0.5 \mathrm{ft}$ higher than the mean of May and September measured water levels, with a maximum difference of $1.3 \mathrm{ft}$. The 0.5 -ft difference is considerably smaller than the range of water-level fluctuations typically observed in Upper Floridan aquifer monitoring wells in 1988 (about $5 \mathrm{ft}$ in well OR-47, fig. 11), indicating that the average of May and September measured heads could have been used as a reasonable estimate of the true annual average.

Water-level data collected from 1980 to 1990 in Upper Floridan aquifer monitoring well OR-47 are typical of data from other wells in the study area and indicate that, for 1988 and the proceeding 2 to 3 years, the potentiometric surface was in a "quasi" steady-state condition (fig. 11); that is, the average annual water level about which seasonal highs and lows fluctuated remained relatively constant at about $59 \mathrm{ft}$ above sea level with little net change in head from the beginning to the end of 1988. Water-level declines in 1981, 1985, 1989, and 1990 reflect drought conditions when rainfall was significantly less than 51 in, the long-term annual average.

Water levels in the surficial aquifer system, as inferred from lake levels in the study area, have been less affected by development than have water levels in the Upper Floridan aquifer. The differences between historic lake-level altitudes, as shown on USGS quadrangle maps, and those measured at 25 lakes in 1988 are small, generally within 1 to $2 \mathrm{ft}$ (table 2). Many of the lake levels shown on the quadrangle maps were recorded in the mid-to-late 1950's, prior to extensive development. Average 1988 levels measured in 11 of the lakes were higher than respective map-based estimates. Although these data indicate that average 1988 water levels in some lakes were similar to those of the 1950 's, this does not imply that all lake levels (and surficial aquifer system heads) across Orange and Seminole Counties were unaffected by ground-water development. Rainfall in 1988 totaled 56 in. (5 in. above the long-term average) and as a result, 1988 lake levels were slightly higher ( 0 to $1 \mathrm{ft}$ ) compared to the average levels during the 1980's and early 1990's (USGS, Orange County, and Seminole County data files).

Detailed potentiometric surface maps cannot be constructed for the Lower Floridan aquifer because few wells penetrate the aquifer within the study area. However, in June 1962 Lichtler and others (1968, p. 99) constructed a potentiometric surface map of the Lower Floridan aquifer in the downtown Orlando area from data collected at 11 public-supply wells. The general configuration of the Lower Floridan potentiometric surface was a subdued reflection of the Upper Floridan potentiometric surface, with Upper Floridan aquifer heads 1 to $3 \mathrm{ft}$ higher than Lower Floridan aquifer heads.

\section{Conceptual Model of Ground-Water Flow}

A conceptual model of ground-water flow in the Floridan aquifer system is shown in figure 12. Hydrogeologic section $\mathrm{A}-\mathrm{A}^{\prime}$ is aligned along row 10 of the grid used for the digital flow model discussed later in this report.

Water in the Upper Floridan aquifer generally flows east and northeast in the direction of declining head. The Upper Floridan aquifer is recharged by the surficial aquifer system in areas where the water table is higher than the potentiometric surface of the Upper Floridan aquifer. Water in the Floridan aquifer system 

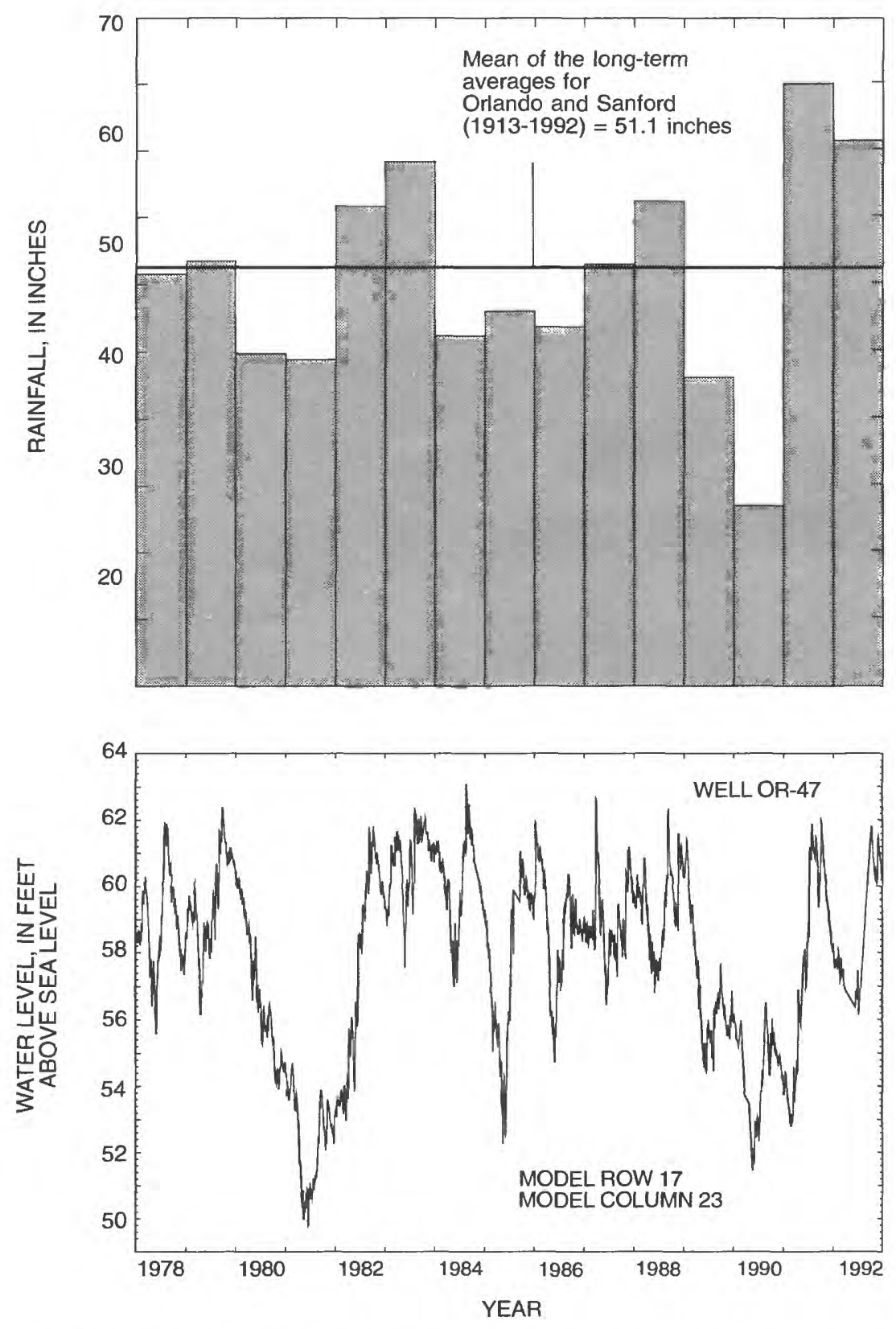

Figure 11. Average rainfall for Orlando and Sanford and water levels in Upper Floridan aquifer monitoring well OR-47, 1978-92.

is eventually discharged at Upper Floridan aquifer springs, by diffuse upward leakage in areas where the water table is below the potentiometric surface of the Upper Floridan aquifer, by undocumented spring flow, and as lateral outflow toward the Atlantic Ocean. Water generally moves laterally within the aquifers and vertically through the confining units. In areas where the potentiometric surface of the Upper Floridan aquifer indicates a ground-water flow divide, water in the aquifer flows laterally in directions opposite and perpendicular to the divide. Ground-water flow divides occur between the Wekiva River and Lake Jesup in Seminole County and in north Brevard County near the Volusia-Brevard County line (fig. 12).

The middle semiconfining unit serves as a leaky base for the Upper Floridan aquifer. In areas near downtown Orlando, where large quantities of water are pumped from the Lower Floridan aquifer, downward leakage from the Upper Floridan aquifer is a major source of recharge to the Lower Floridan. Elsewhere, 
Table 2. Average 1988 lake water levels based on monthly observations and lake water levels estimated from USGS quadrangle maps

[Elevation is in feet above sea level. OCPUD, Orange County Public Utilities Department (Stormwater Division) data files; SEMCO, Seminole County data files; USGS, U.S. Geological Survey data files]

\begin{tabular}{|c|c|c|c|c|c|c|c|c|}
\hline \multirow[b]{2}{*}{$\begin{array}{c}\text { Name } \\
\text { of } \\
\text { lake }\end{array}$} & \multirow[b]{2}{*}{$\begin{array}{l}\text { Model } \\
\text { row }\end{array}$} & \multirow[b]{2}{*}{$\begin{array}{l}\text { Model } \\
\text { column }\end{array}$} & \multirow{2}{*}{$\begin{array}{c}\text { Average } \\
1988 \\
\text { elevation } \\
(1) \\
\end{array}$} & \multirow[b]{2}{*}{$\begin{array}{c}\text { Source of } \\
\text { lake-level } \\
\text { data }\end{array}$} & \multicolumn{3}{|c|}{ USGS quadrangle topographic survey } & \multirow{2}{*}{$\begin{array}{c}\text { Difference } \\
\text { in lake level, } \\
\text { in feet } \\
(2)-(1)\end{array}$} \\
\hline & & & & & $\begin{array}{l}\text { Estimated } \\
\text { elevation } \\
\text { (2) }\end{array}$ & Map name & Year & \\
\hline Prevatt & 13 & 16 & 55.0 & OCPUD & 57.0 & Forest City & 1959 & 2.0 \\
\hline Barton & 22 & 27 & 92.7 & OCPUD & 93.0 & Orlando East & 1956 & 0.3 \\
\hline Bay & 20 & 20 & 90.4 & OCPUD & 91.0 & Orlando West & 1956 & 0.6 \\
\hline Bear & 16 & 19 & 104.8 & SEMCO & 104.0 & Forest City & 1959 & -0.8 \\
\hline Black & 24 & 9 & 94.0 & OCPUD & 94.0 & Winter Garden & 1956 & 0.0 \\
\hline Bosse & 17 & 20 & 60.4 & OCPUD & 61.0 & Forest City & 1959 & 0.6 \\
\hline Brantley & 14 & 20 & 46.3 & SEMCO & 48.0 & Forest City & 1959 & 1.7 \\
\hline Butler & 26 & 12 & 99.7 & USGS & 98.0 & Windermere & 1953 & -1.7 \\
\hline Charm & 15 & 34 & 46.3 & SEMCO & 45.0 & Oviedo & 1956 & -1.3 \\
\hline Clear & 24 & 21 & 94.6 & OCPUD & 92.0 & Orlando West & 1956 & -2.6 \\
\hline Conway & 27 & 24 & 86.7 & USGS & 86.0 & Pine Castle & 1953 & -0.7 \\
\hline Fairview & 20 & 21 & 87.7 & OCPUD & 88.0 & Orlando West & 1956 & 0.3 \\
\hline Flat & 26 & 5 & 85.7 & OCPUD & 89.0 & Lake Louisa & 1959 & 3.3 \\
\hline Formosa & 21 & 23 & 71.8 & OCPUD & 73.0 & Orlando West & 1956 & 1.2 \\
\hline Geneva & 11 & 39 & 24.3 & SEMCO & 27.0 & Geneva & 1953 & 2.7 \\
\hline Howell & 17 & 27 & 53.1 & SEMCO & 53.0 & Casselberry & 1962 & -0.1 \\
\hline Huckleberry & 29 & 9 & 96.8 & OCPUD & 96.0 & Windermere & 1953 & -0.8 \\
\hline Jessamine & 27 & 22 & 91.4 & OCPUD & 89.0 & Lake Jessamine & 1953 & -2.4 \\
\hline Kathryn & 18 & 29 & 50.8 & SEMCO & 52.0 & Casselberry & 1962 & 1.2 \\
\hline Lotta & 22 & 15 & 87.5 & OCPUD & 85.0 & Winter Garden & 1956 & -2.5 \\
\hline Mann & 23 & 20 & 90.8 & OCPUD & 90.0 & Orlando West & 1956 & -0.8 \\
\hline Mary & 11 & 27 & 39.0 & SEMCO & 40.0 & Casselberry & 1962 & 1.0 \\
\hline Mirror & 16 & 19 & 61.3 & SEMCO & 60.0 & Forest City & 1959 & -1.3 \\
\hline Orienta & 16 & 23 & 61.2 & SEMCO & 61.0 & Casselberry & 1962 & -0.2 \\
\hline Sylvan & 7 & 23 & 38.6 & SEMCO & 40.0 & Sanford SW & 1965 & 1.4 \\
\hline
\end{tabular}

${ }^{\text {a }}$ Mean of twelve monthly lake-level measurements.

recharge to the Lower Floridan aquifer from the Upper Floridan aquifer probably occurs beneath the higher topographic areas of east Lake and west Orange Counties. Generally, however, relatively little water is exchanged between the two aquifers (Tibbals, 1981; 1990). The Lower Floridan aquifer is underlain by an impermeable lower confining unit which serves as the base of the freshwater-flow system in much of the study area.

Ground-water flow velocities generally are greater in the Upper Floridan aquifer than in the Lower Floridan aquifer. Shorter flow paths between recharge areas and springs, as well as the increased potential for dissolution of carbonate minerals by shallower circulating recharge water, contribute to this condition
(Bush, 1982, p. 17). The highest ground-water velocities in the Upper Floridan aquifer occur in areas close to and upgradient from the springs, where transmissivity is high and converging flow lines induce relatively large local hydraulic gradients. Flow velocities in the Upper Floridan aquifer probably are relatively slow where potentiometric-surface gradients are small and transmissivity is low. Lowest flow velocities probably occur in the aquifer just northeast of Lake Harney and downgradient from Upper Floridan aquifer springs. The reduced circulation of ground water immediately downgradient from the springs limits the potential for formation of secondary porosity and enhanced aquifer transmissivity. 


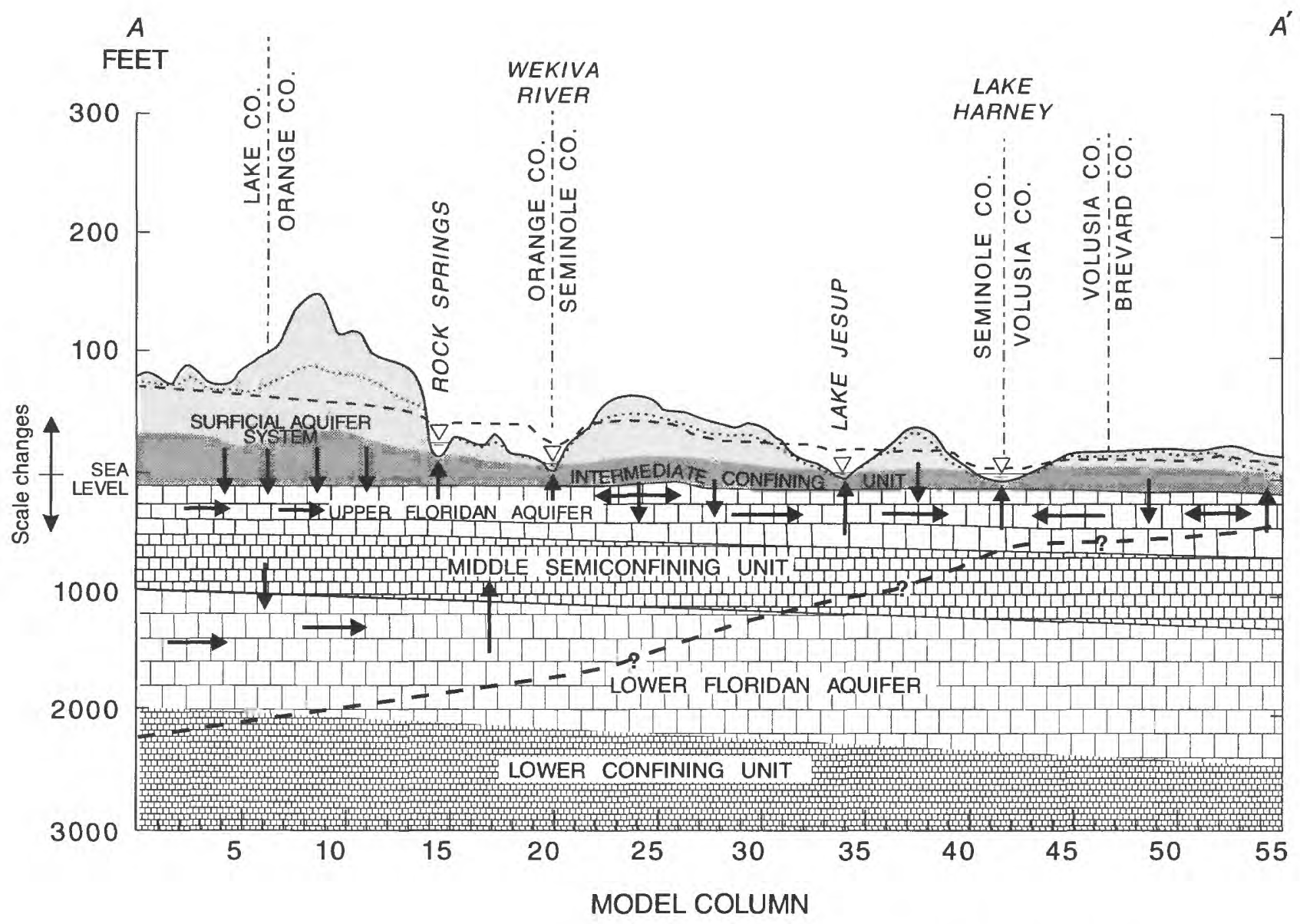

VERTICAL SCALE VARIES AND IS GREATLY EXAGGERATED

EXPLANATION
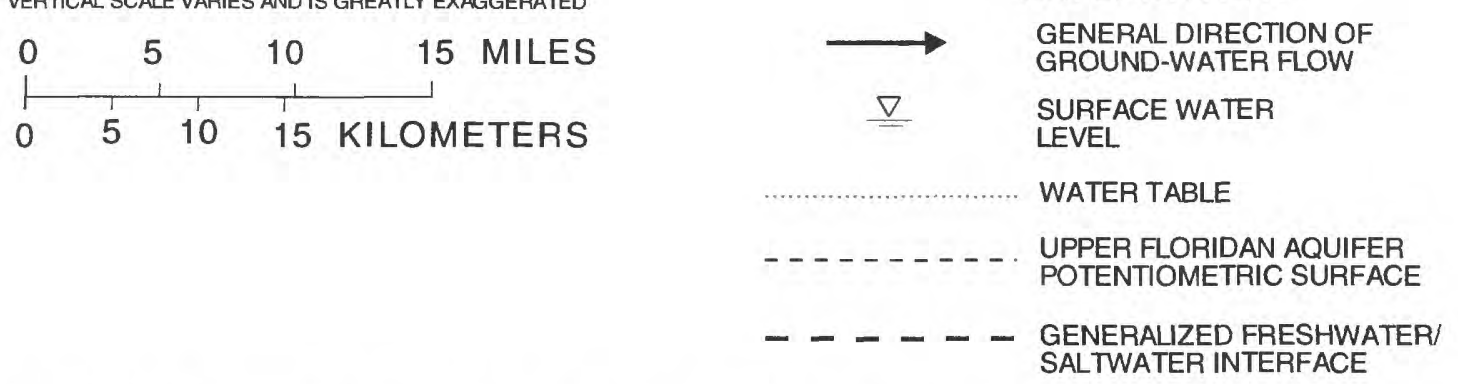

Figure 12. Hydrogeologic section and conceptualized ground-water flow along model row 10, columns 1-55. Trace of section A-A' shown in figure 3.

\section{Water Quality}

Water in the Floridan aquifer system generally is of a calcium and magnesium bicarbonate type because of the reaction between the limestone aquifer matrix and the weak carbonic acid characteristic of rainfall as a source of recharge. Water in the Lower Floridan aquifer tends to be more highly mineralized than water in the Upper Floridan aquifer, indicative of longer flow paths and greater contact time with the aquifer matrix.
In discharge areas around the St. Johns and Wekiva Rivers, the Upper Floridan aquifer contains highly mineralized relict seawater that entered the aquifer during a higher stand of the sea in past geologic time (Tibbals, 1990). The relict seawater in these areas moves upward in the direction of decreasing hydraulic head and mixes with fresher water in the aquifer that moves laterally toward these rivers.

Concentrations of dissolved solids, chloride, and sulfate vary widely across the study area (figs. 13-15). 
Figures 13-15 were adapted from maps published by Tibbals (1990) and modified to include recent and more detailed data collected in the Wekiva River basin by Toth and others (1989), in northeast Seminole County by Phelps and Rohrer (1987), and at the Cocoa well field by the USGS (1993). For the purposes of this report, brackish water is defined by the constituent concentration ranges shown in table 3 . Water-quality data used to bracket the fresher range of constituent concentrations were acquired from wells that typically penetrate most, if not all, of the Upper Floridan aquifer. As a result, the indicated ranges are considered to represent average concentrations with respect to the full thickness of the aquifer. Wells drilled within the

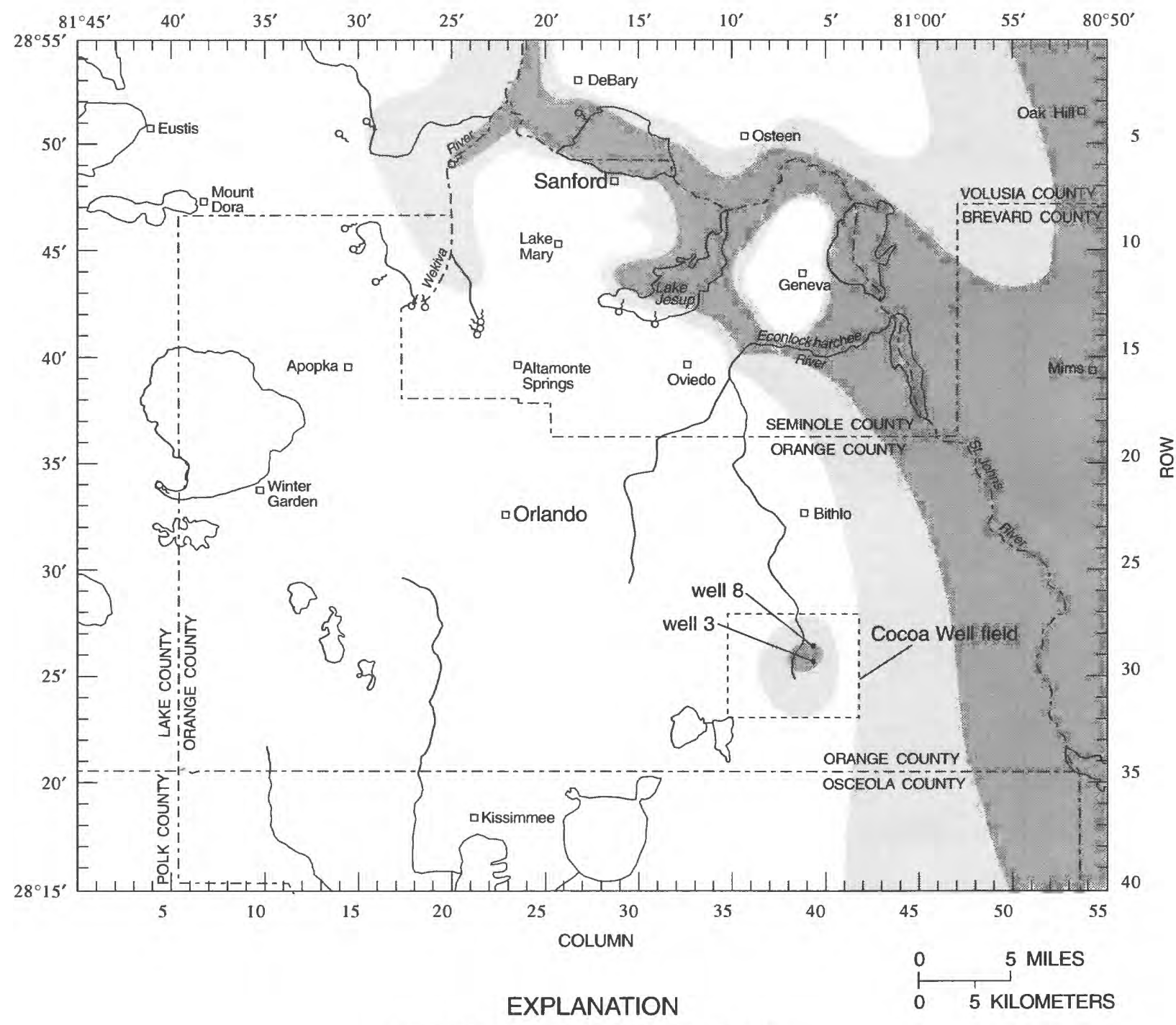

DISSOLVED SOLIDS CONCENTRATION, IN MILLIGRAMS PER LITER

Less than 500

$500-1,000$

Greater than 1,000

Figure 13. Dissolved solids concentrations in water in the Upper Floridan aquifer (adopted from Tibbals, 1990). 


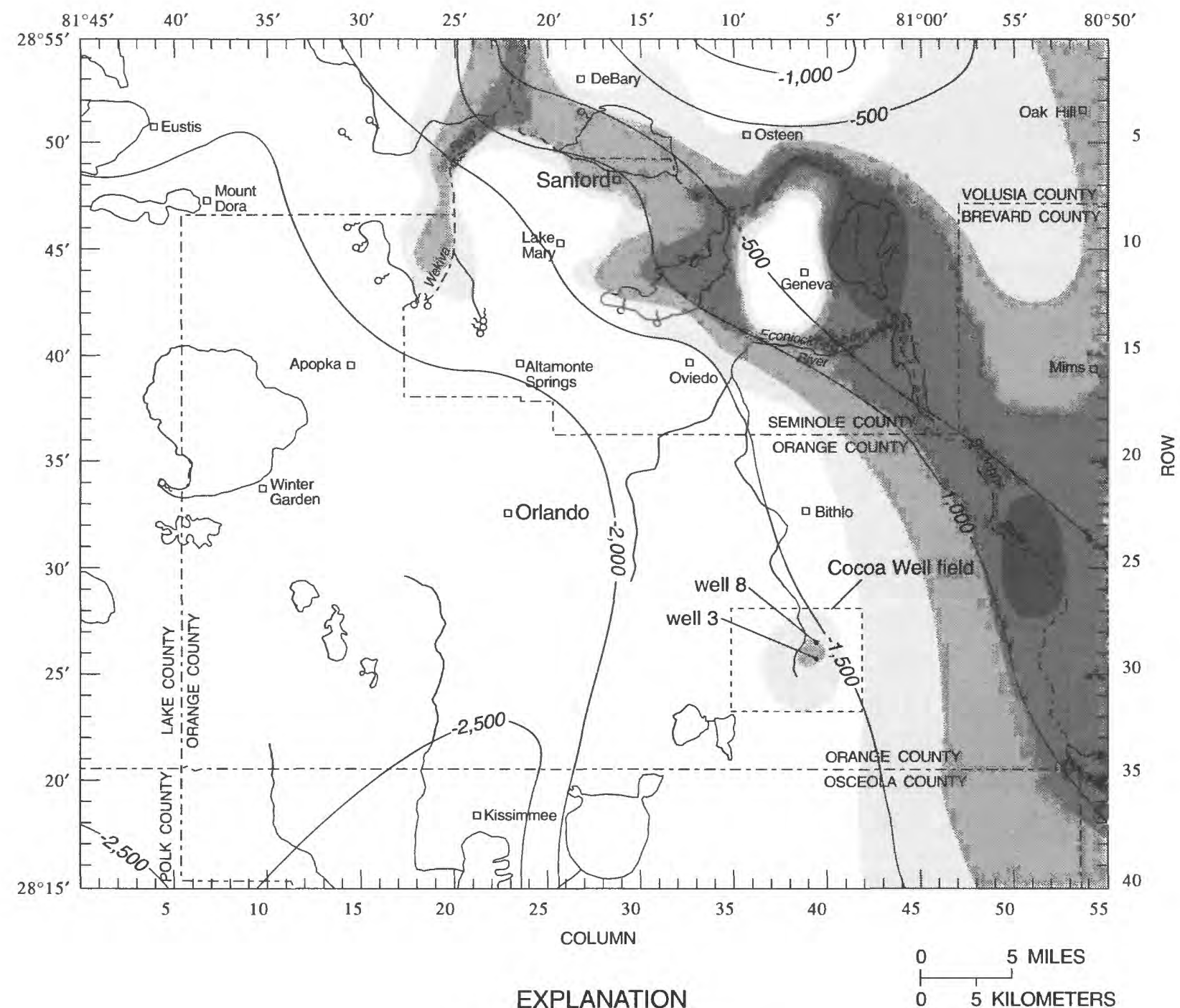

CHLORIDE CONCENTRATION

IN MILLIGRAMS PER LITER

$\square$ Less than 100
$100-250$
$251-1,000$
$1,001-4,000$
Greater than 4,000
$-2,000 \_$LINE OF EQUAL DEPTH TO WATER WITH CHLORIDE CONCENTRATION OF 10,000 MILLIGRAMS PER LITER OR GREATER - Interval 500 feet. Datum is sea level

Figure 14. Chloride concentrations in water in the Upper Floridan aquifer and estimated depth to water containing chloride concentrations greater than 10,000 milligrams per liter (adapted from Rutledge (1985); Phelps and Rohrer (1987); Toth and others (1989); Tibbals (1990); and Schiner (1993)). 


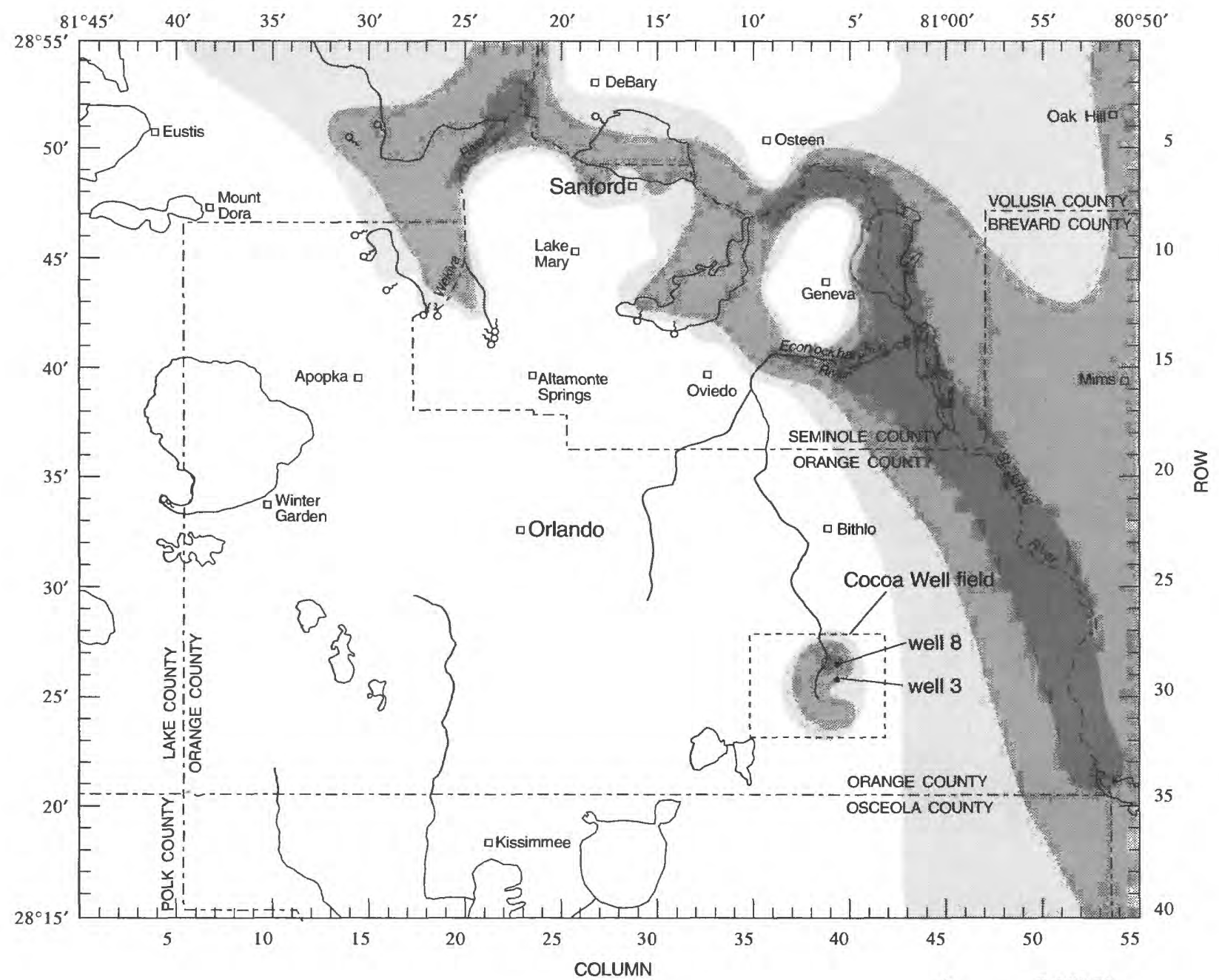

EXPLANATION

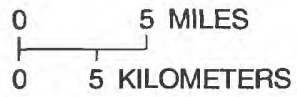

SULFATE CONCENTRATION, IN MILLIGRAMS PER LITER'

Less than 50

$50-100$

$101-250$

Greater than 250

Figure 15. Sulfate concentrations in water in the Upper Floridan aquifer (adapted from Phelps and Rohrer (1987); Toth and others (1989); and Tibbals (1990)). 
more brackish areas, however, usually penetrate less of the aquifer and the higher concentrations of the bracketed ranges represent average concentrations for only the top 100 to $200 \mathrm{ft}$. Constituent concentrations at greater depths may be considerably higher than the upper limit of these ranges.

Table 3. Typical concentrations of dissolved solids, hardness, sulfate, and chloride in freshwater, brackish water, and seawater

[Constituent concentrations in milligrams per liter; <, less than; $\mathrm{CaCO}_{3}$, calcium carbonate]

\begin{tabular}{lrcr}
\hline \multicolumn{1}{c}{ Constituent } & $\begin{array}{c}\text { Fresh- } \\
\text { water }\end{array}$ & $\begin{array}{c}\text { Brackish } \\
\text { water }\end{array}$ & $\begin{array}{c}\text { Sea- } \\
\text { water }\end{array}$ \\
\hline Dissolved solids & $<1,000$ & $1,000-35,000$ & 35,000 \\
Hardness as $\mathrm{CaCO}_{3}$ & $<400$ & $400-6.600$ & 6,600 \\
Sulfate & $<250$ & $250-2,700$ & 2,700 \\
Chloride & $<250$ & $250-19,000$ & 19,000 \\
\hline
\end{tabular}

The extent to which water in the Upper Floridan aquifer is mineralized can be described by its concentration of dissolved solids. The freshest water in the study area is characterized by dissolved solids concentrations less than $500 \mathrm{mg} / \mathrm{L}$ (the drinking water standard set by the Florida Department of Environmental Regulation, 1982). Water containing the lowest concentrations of dissolved solids occurs in west and central Orange, southwest Seminole, east Lake, and southwest Volusia Counties (fig. 13). In these areas, recharge to the aquifer from rainfall occurs at a relatively high rate through a thin or breached intermediate confining unit. Brackish water (dissolved solids concentration greater than $1,000 \mathrm{mg} / \mathrm{L}$ ) occurs in discharge areas beneath the St. Johns River and adjoining lakes, beneath the Wekiva River, and near the Atlantic coast. Brackish water beneath the St. Johns and Wekiva Rivers probably results from the mixing of freshwater with relict seawater. Movement of this brackish water is relatively slow, particularly beneath the St. Johns River from Lake Harney northward. The relatively small amounts of water that are discharged from the Upper Floridan aquifer to the St. Johns and Wekiva Rivers by diffuse upward leakage and undocumented spring flow are being replenished by the upward movement of deeper and more saline water. A discussion of the origin and flushing of brackish water in the Floridan aquifer system in east-central Florida is provided by Tibbals (1990).

Brackish water also occurs in two Upper Floridan aquifer wells (Cocoa 3 and Cocoa 8) located in the east part of the Cocoa well field, in east Orange County. The occurrence of this slightly brackish water may be the result of induced upward leakage of more brackish water from depth in the Floridan aquifer (Tibbals and Frazee, 1976). Such leakage could occur through fractures in the aquifer near these wells. Another possible source of this brackish water is a local pocket of entrapped relict seawater that exists near or below pumping wells. Water-quality data collected during recent test drilling at the Cocoa well field indicate that fresh and saltier (relict) water may be layered within the Upper Floridan aquifer, possibly the result of fluctuating sea levels over geologic time (Phelps and Schiffer, 1996). Lateral intrusion of brackish water from the east is also a potential source of brackish water at the well field. However, water sampled from wells located less than a mile north and south of Cocoa 3 and Cocoa 8 is considerably less mineralized, inferring a more localized source of brackish water moving along preferential flow paths. Samples collected from an Upper Floridan aquifer monitoring well constructed 1 to 2 mi east of wells Cocoa 3 and Cocoa 8 could be used to evaluate the likelihood of lateral intrusion. If the sampled water was less mineralized than water in wells Cocoa 3 and Cocoa 8 , it would be unlikely that the lateral movement of brackish water from a nonlocal source (east of the well field nearer the St. Johns River) was contributing to the condition at the Cocoa wells.

Chloride is the predominant anion in seawater and is an important indicator of brackish water in the Upper Floridan aquifer. Water containing chloride at concentrations greater than $250 \mathrm{mg} / \mathrm{L}$ is considered brackish and unfit for human consumption (Florida Department of Environmental Regulation, 1982). Concentrations of chloride in the Upper Floridan aquifer range from less than $100 \mathrm{mg} / \mathrm{L}$ in west and central Orange, southwest Seminole, east Lake, and southwest Volusia Counties, to greater than $4,000 \mathrm{mg} / \mathrm{L}$ along the course of the St. Johns River in east-central Orange and east Seminole Counties and along the Wekiva River in northwest Seminole County (fig. 14). Concentrations of less than $30 \mathrm{mg} / \mathrm{L}$ are common in recharge areas where fresh percolating rainfall more easily infiltrates the aquifer.

The lateral transition from freshwater to brackish water within the Upper Floridan aquifer is particularly abrupt in northeast Seminole County at the Geneva "bubble." This isolated lens of freshwater is about $350 \mathrm{ft}$ thick at its center and is surrounded by 
brackish water. Chloride concentrations near the edge of the bubble increase from less than $100 \mathrm{mg} / \mathrm{L}$ to greater than $4,000 \mathrm{mg} / \mathrm{L}$ in less than a mile. The Geneva bubble was originally formed and is now sustained by the local flushing of relict seawater by recharge from rainfall. Recharge rates to the bubble from the surficial aquifer system have been estimated at 10 to $13 \mathrm{in} / \mathrm{yr}$ (Phelps and Rohrer, 1987).

The vertical location of the freshwater-saltwater interface defines the vertical extent of the freshwater-flow system. For the purposes of this study, this interface is defined by the $10,000-\mathrm{mg} / \mathrm{L}$ isochlor and approximates the midrange of the transition zone between freshwater and saltwater. The depth to the freshwater-saltwater interface is estimated to range from about 2,500 ft below sea level in southwest Orange County to less than $500 \mathrm{ft}$ below sea level in east Seminole County (Tibbals, 1990) (fig. 14).

The isochlors depicted in figure 14 were slightly modified from Tibbals (1990) to include data collected in 1993 and 1994 from two deep monitoring wells drilled in Seminole County near the cities of Oviedo and Altamonte Springs. Chloride concentrations in water sampled from the Oviedo well increased abruptly with depth from less than $1,000 \mathrm{mg} / \mathrm{L}$ at $1,380 \mathrm{ft}$ below land surface to nearly $7,000 \mathrm{mg} / \mathrm{L}$ at the wells's maximum depth of 1,607 ft below land surface (Yovaish Engineering Sciences, Inc., 1994). A chloride concentration of $11 \mathrm{mg} / \mathrm{L}$ was reported for the Altamonte Springs site at the terminal depth of 1,506 ft below land surface (Ardaman and Associates, Inc., 1993).

The areal distribution of sulfate concentrations in the Upper Floridan aquifer is very similar to those of chloride and dissolved solids (fig. 15). Sulfate concentrations of less than $50 \mathrm{mg} / \mathrm{L}$ occur across much of the study area, with concentrations of less than $20 \mathrm{mg} / \mathrm{L}$ found in high-rate recharge areas. The highest sulfate concentrations (greater than $250 \mathrm{mg} / \mathrm{L}$ ) are found along the St. Johns River in east Orange and Seminole Counties, and beneath the Wekiva River in northwest Seminole County. Relatively high sulfate concentrations measured near Lake Harney result from the mixing of freshwater with relict seawater and, to a lesser extent, from the dissolution of gypsum (calcium sulfate) within the aquifer matrix (Phelps and Rohrer, 1987, p. 51).

The quality of water discharging from Upper Floridan aquifer springs varies considerably (table 4). Water sampled at Wekiva, Rock, Sanlando, Palm, Starbuck, Miami, and Witherington Springs in May 1993 contained low concentrations of chloride (less than $20 \mathrm{mg} / \mathrm{L}$ ), sulfate (less than $30 \mathrm{mg} / \mathrm{L}$ ), and dissolved solids (less than $250 \mathrm{mg} / \mathrm{L}$ ). Based on an analysis of major cations and anions, water from these seven springs is classified as a calcium-magnesium bicarbonate type that results from dissolution of the calcium carbonate (limestone) aquifer matrix and probably travels along relatively short, lateral flow paths that originate in high-rate recharge areas (fig. 16). Water sampled from Seminole and Messant Springs is more highly mineralized and contains higher concentrations of sulfate $(120 \mathrm{mg} / \mathrm{L}$ and $240 \mathrm{mg} / \mathrm{L}$, respectively). This calcium sulfate type water results from the dissolution of a calcium sulfate aquifer matrix and probably travels along longer and deeper flow paths than the fresher calcium-magnesium bicarbonate type water discharged by the other

Table 4. Chloride, sulfate, and dissolved solids concentrations in selected Upper Floridan aquifer springs, May 1993, and average values

[Discharge in cubic feet per second; constituent concentrations in milligrams per liter]

\begin{tabular}{|c|c|c|c|c|c|c|c|c|c|c|}
\hline \multirow[b]{2}{*}{ Name } & \multirow[b]{2}{*}{$\begin{array}{c}1988 \\
\text { average } \\
\text { discharge }\end{array}$} & \multicolumn{3}{|c|}{ Chloride } & \multicolumn{3}{|c|}{ Sulfate } & \multicolumn{3}{|c|}{ Dissolved solids } \\
\hline & & $\begin{array}{c}\text { May } \\
1993\end{array}$ & Average & $\begin{array}{c}\text { Number } \\
\text { of } \\
\text { samples }\end{array}$ & $\begin{array}{c}\text { May } \\
1993\end{array}$ & Average & $\begin{array}{c}\text { Number } \\
\text { of } \\
\text { samples }\end{array}$ & $\begin{array}{l}\text { May } \\
1993\end{array}$ & Average & $\begin{array}{c}\text { Number } \\
\text { of } \\
\text { samples }\end{array}$ \\
\hline Wekiva & 69 & 13 & 10 & 19 & 17 & 12 & 19 & 182 & 148 & 17 \\
\hline Rock & 58 & 8 & 7 & 21 & 19 & 17 & 21 & 145 & 132 & 20 \\
\hline Sanlando & 20 & 15 & 11 & 6 & 12 & 8 & 6 & 192 & 165 & 4 \\
\hline Palm & 6 & 14 & 10 & 5 & 21 & 16 & 5 & 211 & 161 & 4 \\
\hline Starbuck & 15 & 19 & 14 & 5 & 22 & 16 & 5 & 192 & 163 & 4 \\
\hline Miami & 5 & 10 & 8 & 3 & 8 & 6 & 3 & 148 & 134 & 2 \\
\hline Seminole & 39 & 8 & 7 & 3 & 120 & 80 & 3 & 286 & 228 & 3 \\
\hline Messant & 14 & 10 & 10 & 5 & 240 & 230 & 5 & 503 & 492 & 4 \\
\hline Witherington & 1 & 8 & 7 & 3 & 10 & 11 & 3 & 142 & 139 & 2 \\
\hline Gemini & 8 & 600 & 590 & 2 & 120 & 120 & 2 & 1,430 & 1,315 & 2 \\
\hline
\end{tabular}




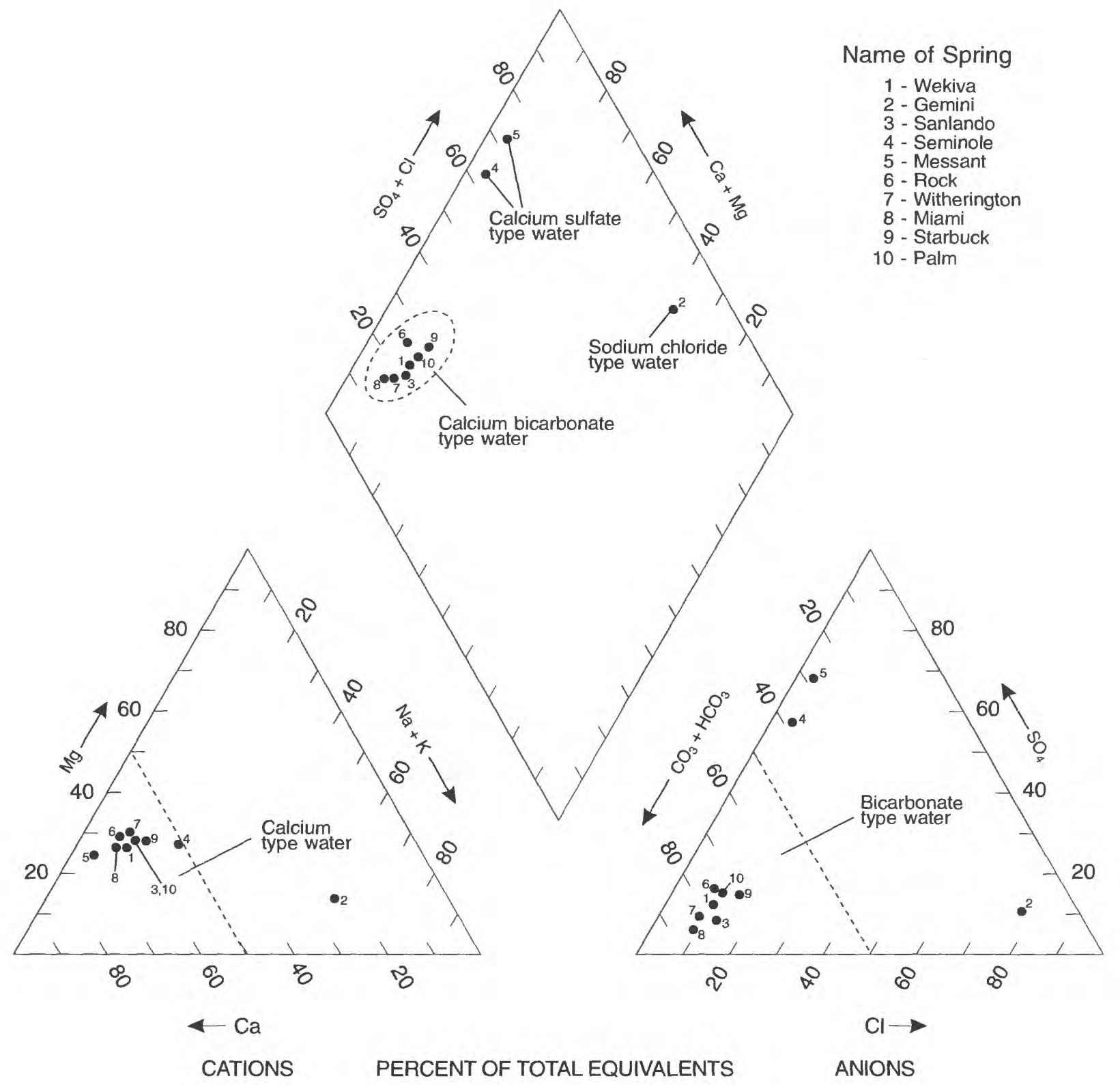

Figure 16. Major cations and anions in water from Upper Floridan aquifer springs.

springs. At Gemini Spring, sampled water contained brackish concentrations of chloride $(600 \mathrm{mg} / \mathrm{L})$. This sodium chloride type water probably results from the mixing of freshwater with entrapped relict seawater or from the upwelling of deeper brackish water through fractures.

Water discharged from Upper Floridan aquifer springs has become more mineralized with time. At Wekiva Springs, the specific conductance of discharged water (an indirect measurement of the concentration of dissolved solids) has increased from about
$225 \mu \mathrm{S} / \mathrm{cm}$ in 1956 to about $300 \mu \mathrm{S} / \mathrm{cm}$ in 1993 (fig. 17). Moreover, the concentrations of chloride, sulfate, and dissolved solids determined from the most recent (May 1993) USGS sampling of selected springs exceed respective mean concentrations determined from previous sampling events (table 4). Although the increases are relatively small, they do indicate the potential for further degradation of springwater quality. The causes for the observed increases are unknown. 
At the Cocoa well field, chloride concentrations measured in the Upper Floridan aquifer at Cocoa C, a multi-zoned monitoring well, have increased from $50 \mathrm{mg} / \mathrm{L}$ in 1966 to about $120 \mathrm{mg} / \mathrm{L}$ in 1994 (fig. 18). Concentrations measured in the Lower Floridan aquifer at Cocoa $\mathrm{C}$ have increased from about $600 \mathrm{mg} / \mathrm{L}$ in 1966 to nearly $3,000 \mathrm{mg} / \mathrm{L}$ in 1994 . It is unlikely that a regional upconing of the freshwater-saltwater inter-

face and the brackish transition zone is contributing to the water-quality changes observed in the Upper Floridan aquifer at Cocoa $\mathrm{C}$ because chloride concentrations measured in the intervening zones between the Upper and Lower Floridan aquifers have not changed. Increased chloride concentrations at Cocoa $\mathrm{C}$ probably result from the local movement of brackish water laterally from the east part of the well field. A more detailed discussion of water-quality conditions in the Floridan aquifer system at the Cocoa well field is provided by Phelps and Schiffer (1996).

\section{SIMULATION OF GROUND-WATER FLOW}

The conceptual model and hydrologic data discussed in the previous section were used to construct a digital computer ground-water flow model of the Floridan aquifer system. The model simulates both predevelopment and post-development (1988) steady-state ground-water flow conditions, as well as the transient declines in Upper Floridan aquifer heads observed during the drought period from January to May 1990. The model also was used to evaluate the response of the flow system to projected ground-water pumpage in the year 2010. Particle-tracking simulations were used to identify potential changes in areas that contribute recharge to selected springs and well fields under proposed 2010 pumping conditions and to delineate the possible flow paths and destinations of surface water that recharges the Upper Floridan aquifer through two high-capacity drainage wells.

\section{Model Description}

The USGS three-dimensional finite-difference ground-water flow model MODFLOW (McDonald and Harbaugh, 1988) was used to simulate the flow system. MODFLOW uses a finite-difference method to numerically solve a system of partial differential equations that describe the response of ground-water flow to hydrologic stresses and specified boundary conditions. The hydrologic system described in the previous section was modeled as three aquifer layers with each layer separated by a confining bed (fig. 4). The Upper and Lower Floridan aquifers were each represented as an active model layer in which heads were calculated by the model, not imposed by the user. Flow simulated within aquifer layers is horizontal because calculated heads are assumed constant with depth. The surficial aquifer system was represented by the third, and uppermost, model layer. Heads within this layer were not simulated by the model, but were assigned by the user to provide a constant source or sink of water to or from the Floridan aquifer system. The intermediate confining unit and the middle semi-

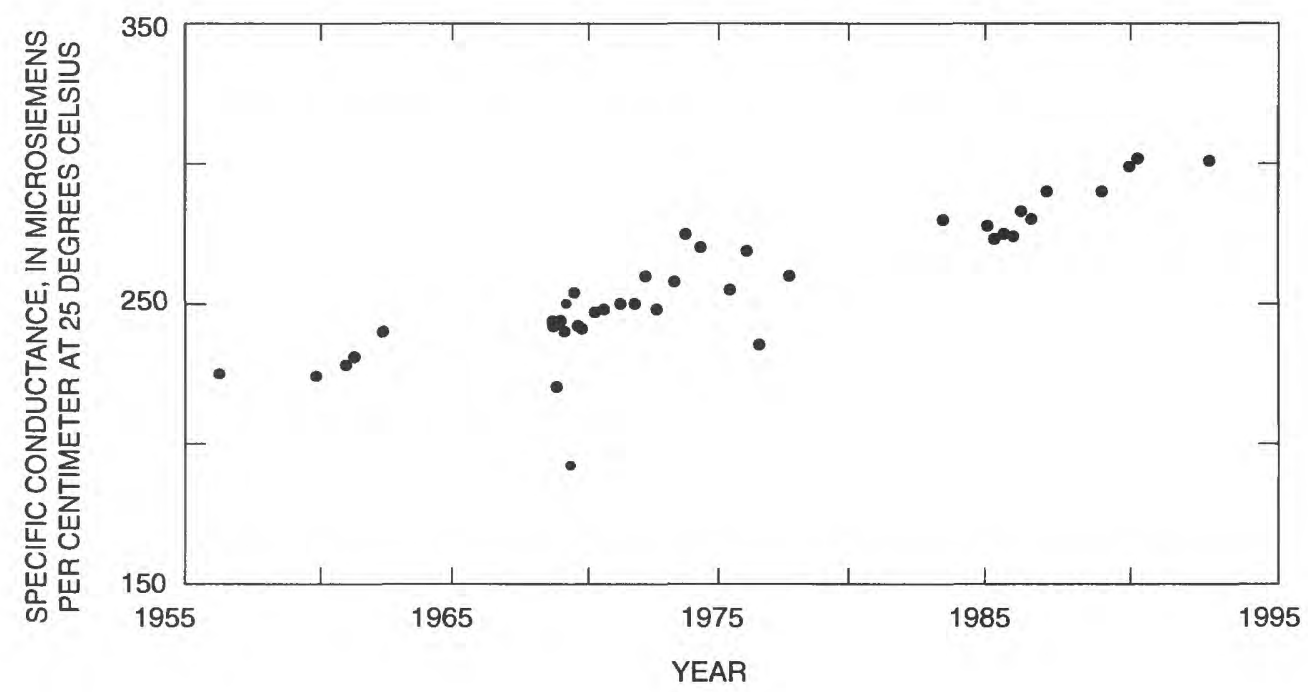

Figure 17. Specific conductance of water discharged from Wekiva Springs, 1956-93. 

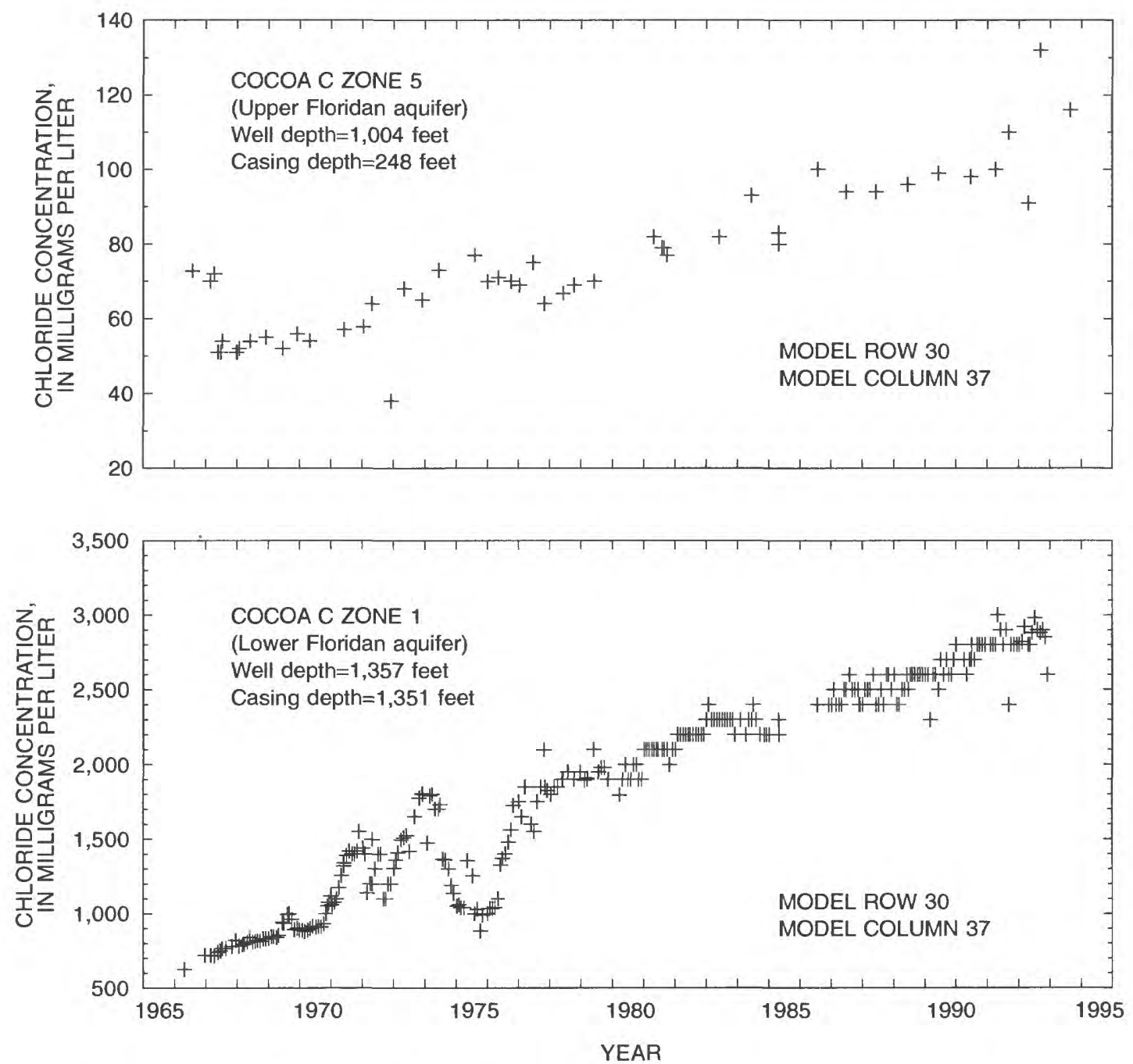

Figure 18. Chloride concentrations in water from zones penetrating the Upper and Lower Floridan aquifers at monitoring well Cocoa C, 1966-94.

confining unit were simulated by arrays of variable leakance (VCONT) values that control the vertical leakage of water between the aquifers. Where the vertical hydraulic conductivity of the aquifer is much greater than that of the adjacent confining unit, leakance is approximately equal to the vertical hydraulic conductivity of the confining unit divided by its thickness. Leakance values can be used to calculate vertical recharge (or discharge) rates from one aquifer to the next by multiplying the head differential between the aquifers by the leakance of the confining unit that separates them. Horizontal flow and changes in storage were not simulated in the confining units.

The study area was subdivided into a finite-difference grid of 40 rows and 55 columns (fig. 19). Each of the 2,200 grid cells was slightly more than $1 \mathrm{mi}^{2}$ in area with dimensions of $6,050 \mathrm{ft}$ in the north-south direction and $5,320 \mathrm{ft}$ in the east-west direction. Grid alignment was essentially along lines of longitude and latitude. The total model area is $2,540 \mathrm{mi}^{2}$.

Model calibration was performed in an iterative fashion, relying on several historic periods of hydrologic record for independent calibration criteria. The model was initially calibrated to reflect 1988 flow conditions by varying selected hydraulic parameters, mainly intermediate confining unit leakance and Upper Floridan aquifer transmissivity, until simulated heads and spring flow were reasonably close to measured values. Next, pumping stresses were set equal to zero and fixed boundary heads were adjusted to simulate the long-term flow conditions that existed prior to extensive ground-water development. Finally, aquifer 


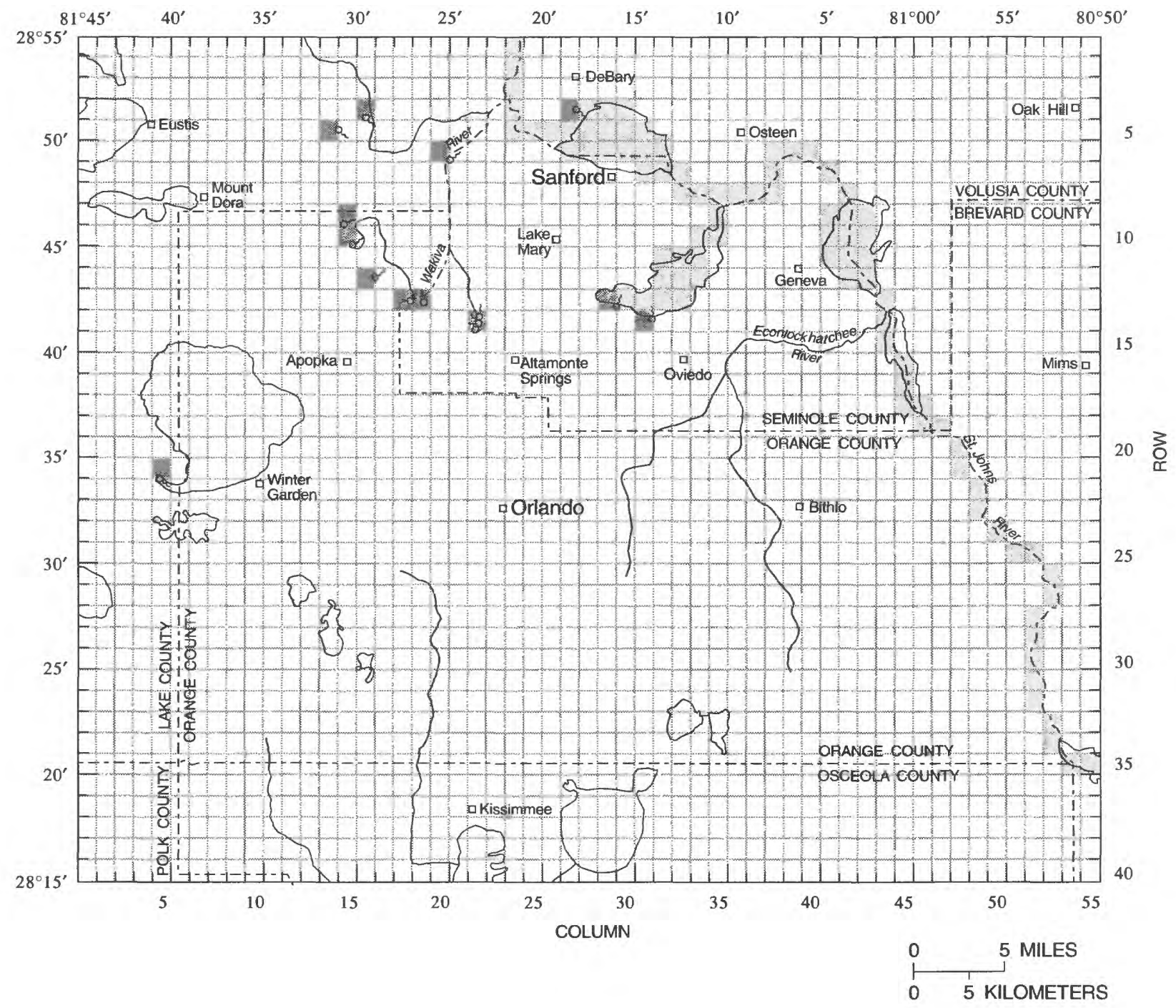

EXPLANATION

Cell in which the vertical flux of water from the Upper Floridan aquifer to the St. Johns River and adjoining lakes is simulated by the RIVER Package

Cell in which the vertical flux of water discharging from Upper Floridan aquifer spring(s) is simulated by the DRAIN Package

Figure 19. Finite-difference grid superimposed on modeled area and locations of Drain and River cells. 
storage coefficients were entered, specified surficial aquifer and boundary heads were adjusted, and pumpage was changed during the transient calibration in which Upper Floridan aquifer water-level declines were simulated during a period of deficient rainfall from January to May 1990.

\section{Boundary Conditions}

The lateral boundaries of the study area do not coincide with any clearly defined hydrogeologic boundaries. Both the Upper Floridan and the Lower Floridan aquifers are confined and laterally continuous across the study area. For this reason, the General-Head Boundary (GHB) Package was used in both steady-state and transient simulations to calculate the lateral flow rate across each boundary-cell face using the equation (adapted from eq 78, McDonald \& Harbaugh, 1988):

$$
Q=T W \frac{(H B-H S)}{L},
$$

where

$Q$ is the lateral flow rate $\left(\mathrm{ft}^{3} / \mathrm{s}\right)$,

$H B$ is the specified GHB head ( $\mathrm{ft}$ ),

$H S$ is the model-simulated head at the boundary node $(\mathrm{ft})$,

$T$ is the aquifer transmissivity between $H S$ and $H B\left(\mathrm{ft}^{2} / \mathrm{s}\right)$,

$W$ is the width of the cell face perpendicular to flow ( $\mathrm{ft}$ ), and

$L$ is the distance from $H S$ to $H B$ (ft). The quantity $\mathrm{TW} / \mathrm{L}$ is equal to the boundary conductance $\left(\mathrm{ft}^{2} / \mathrm{s}\right)$.

For both predevelopment and average 1988 steady-state simulations, $H B$ for the Upper Floridan aquifer was estimated by superimposing the respective potentiometric surface onto the model grid and identifying the head found at a distance $(L)$ of two cell lengths beyond the gridded area from the adjacent perimeter boundary node. For the transient simulations, $H B$ was estimated from water-level data collected from December 1989 through May 1990 in 14 monitoring wells equipped with continuous water-level recorders and from measurements made in additional monitoring wells in May 1990 (Murray, 1990). Water-level declines measured in wells located near model boundaries ranged from about $1 \mathrm{ft}$ at the Lake Oliver well (near the southwest boundary) to about $3 \mathrm{ft}$ at the Lake Joel well (near the south-central boundary) (fig. 2). Specified GHB-heads for the Lower Floridan aquifer were arbitrarily set $2 \mathrm{ft}$ lower than respective Upper Floridan heads in recharge areas and $2 \mathrm{ft}$ higher than Upper Floridan heads in discharge areas, which is consistent with the limited available data (Tibbals, 1990).

A specified-head, source-sink array was used to represent water-table heads in the surficial aquifer system for steady-state predevelopment and average 1988 conditions. Water-table heads were estimated by superimposing the finite-difference grid on USGS topographic quadrangle maps and, from the many surface-water features, estimating the altitude of the water table at each model node. These data were augmented by surficial aquifer water-level data from published reconnaissance reports (Lichtler and others (1968), Knochenmus and others (1976), and Phelps (1990)); by water-level data collected at 20 surficial aquifer monitoring wells (appendix A); and from data collected at 114 lakes and streams (appendix B). Estimated water-table heads are probably within plus or minus $5 \mathrm{ft}$ (the topographic map contour interval) of long-term average values. The effects of potential errors in specified water-table altitudes on simulated results are evaluated later in this report.

Water-level declines measured in the above-referenced lakes, streams and surficial aquifer wells between 1988 and the middle of each month from January to May 1990 were used to calculate average monthly water-table altitudes used in the transient simulations by subtracting the measured declines from the specified 1988 heads. Estimated water-table declines from 1988 through May 1990 ranged from less than $2 \mathrm{ft}$ in central and east Orange County to about $8 \mathrm{ft}$ beneath the higher karstic sand ridges of west Orange County (fig. 19).

\section{Hydrologic Data Input}

Input data required for the ground-water flow model are summarized in table 5. Included are data used to assign starting values for parameters that were adjusted during model calibration. Parameter values obtained by direct field measurements were not adjusted or were only minimally adjusted during model calibration. 


\begin{tabular}{|c|c|c|c|c|c|}
\hline \multirow[b]{2}{*}{ Model aquifer unit } & \multirow[b]{2}{*}{ Data matrices } & \multicolumn{4}{|c|}{ Matrices required for: } \\
\hline & & 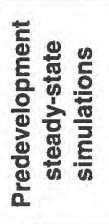 & 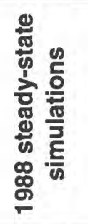 & 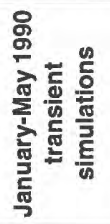 & 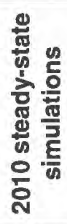 \\
\hline \multirow[t]{3}{*}{ Surficial aquifer system (layer 1) } & -Starting head & $\mathrm{X}$ & $\mathrm{X}$ & $\mathrm{X}$ & $\mathrm{X}$ \\
\hline & - Transmissivity ${ }^{1}$ & -- & -- & -- & -- \\
\hline & -Storage coefficient ${ }^{1}$ & -- & -- & -- & -- \\
\hline Intermediate confining unit (vcont 1 ) & -Leakance & $\mathrm{X}$ & $\mathrm{X}$ & $\mathrm{X}$ & $\mathrm{X}$ \\
\hline \multirow[t]{11}{*}{ Upper Floridan aquifer (layer 2) } & -Starting head & -- & -- & $\mathrm{X}$ & - \\
\hline & -Transmissivity & $\mathrm{X}$ & $X$ & $\mathrm{X}$ & $\mathrm{X}$ \\
\hline & -Storage coefficient & -- & -- & $X$ & -- \\
\hline & -Fixed boundary head (spring pool) & $\mathrm{X}$ & $\mathrm{X}$ & $\mathrm{X}$ & $\mathrm{X}$ \\
\hline & -Boundary conductance (spring pool drain cells) & $\mathrm{X}$ & $\mathrm{X}$ & $\mathrm{X}$ & $\mathrm{X}$ \\
\hline & -Fixed boundary head (river cells) & $\mathrm{X}$ & $\mathrm{X}$ & $\mathrm{X}$ & $\mathrm{X}$ \\
\hline & -Boundary conductance (streambed) & $\mathrm{X}$ & $\mathrm{X}$ & $\mathrm{X}$ & $\mathrm{X}$ \\
\hline & •Fixed general-head boundary head & $\mathrm{X}$ & $\mathrm{X}$ & $\mathrm{X}$ & $\mathrm{X}$ \\
\hline & -General-head boundary conductance & $\mathrm{X}$ & $\mathrm{X}$ & $\mathrm{X}$ & $\mathrm{X}$ \\
\hline & -Direct recharge & - & $\mathrm{X}$ & $\mathrm{X}$ & $\mathrm{X}$ \\
\hline & •Pumpage & -- & $\mathrm{X}$ & $\mathrm{X}$ & $\mathrm{X}$ \\
\hline Middle semiconfining unit (vcont 2) & •Leakance & $\mathrm{X}$ & $\mathrm{X}$ & $\mathrm{X}$ & $\mathrm{X}$ \\
\hline \multirow[t]{6}{*}{ Lower Floridan aquifer (layer 3) } & -Starting head & - & - & $\mathrm{X}$ & -- \\
\hline & -Transmissivity & $\mathrm{X}$ & $\mathrm{X}$ & $\mathrm{X}$ & $\mathrm{X}$ \\
\hline & -Storage coefficient & -- & -- & $\mathrm{X}$ & - \\
\hline & •Fixed general-head boundary head & $\mathrm{X}$ & $\mathrm{X}$ & $\mathrm{X}$ & $\mathrm{X}$ \\
\hline & -General-head boundary conductance & $\mathrm{X}$ & $\mathrm{X}$ & $\mathrm{X}$ & $\mathrm{X}$ \\
\hline & •Pumpage & - & $\mathrm{X}$ & $\mathrm{X}$ & $\mathrm{X}$ \\
\hline
\end{tabular}

\footnotetext{
${ }^{1}$ Matrices not required because surficial aquifer system is treated as a constant-head boundary for the Upper Floridan aquifer.
}

\section{Aquifer and Confining Unit Properties}

Starting values for distributed arrays representing Upper Floridan aquifer transmissivity, Lower Floridan aquifer transmissivity, intermediate confining unit leakance, and middle semiconfining unit leakance were taken from Tibbals (1990) and adjusted during model calibration. Storage coefficients assigned to the Upper and Lower Floridan aquifers for the transient simulations ranged from $1 \times 10^{-4}$ to $1 \times 10^{-3}$ and are consistent with values reported from aquifer tests.

\section{Spring-Pool Altitude and Conductance}

Discharge from the 15 Upper Floridan aquifer springs was simulated with the MODFLOW Drain Package (fig. 20). The Drain package calculates the head-dependent discharge at each spring by the Darcy equation (adapted from eq 69, McDonald \& Harbaugh, 1988) as:

$$
Q D=C D(H S-H D)
$$

where

$Q D$ is the spring discharge $\left(\mathrm{ft}^{3} / \mathrm{s}\right)$,

$C D$ is the spring conductance $\left(\mathrm{ft}^{2} / \mathrm{s}\right)$,

$H S$ is the model-simulated head in the Upper

Floridan aquifer at the spring node ( $\mathrm{ft})$, and

$H D$ is the spring-pool altitude (ft).

The model-simulated Upper Floridan aquifer head represents the average head across the spring cell and is assumed to prevail at some distance from the spring itself. The spring-pool altitude is localized to the spring itself and is not characteristic of the cell as a whole. Spring-pool altitudes were obtained by direct field measurements or estimated from topographic maps. At Wekiva, Rock, and the Sanlando Spring group, spring-pool altitudes measured in May and September 1988 were 1 to $2 \mathrm{ft}$ lower than predevelopment estimates published by Tibbals (1981) and from 

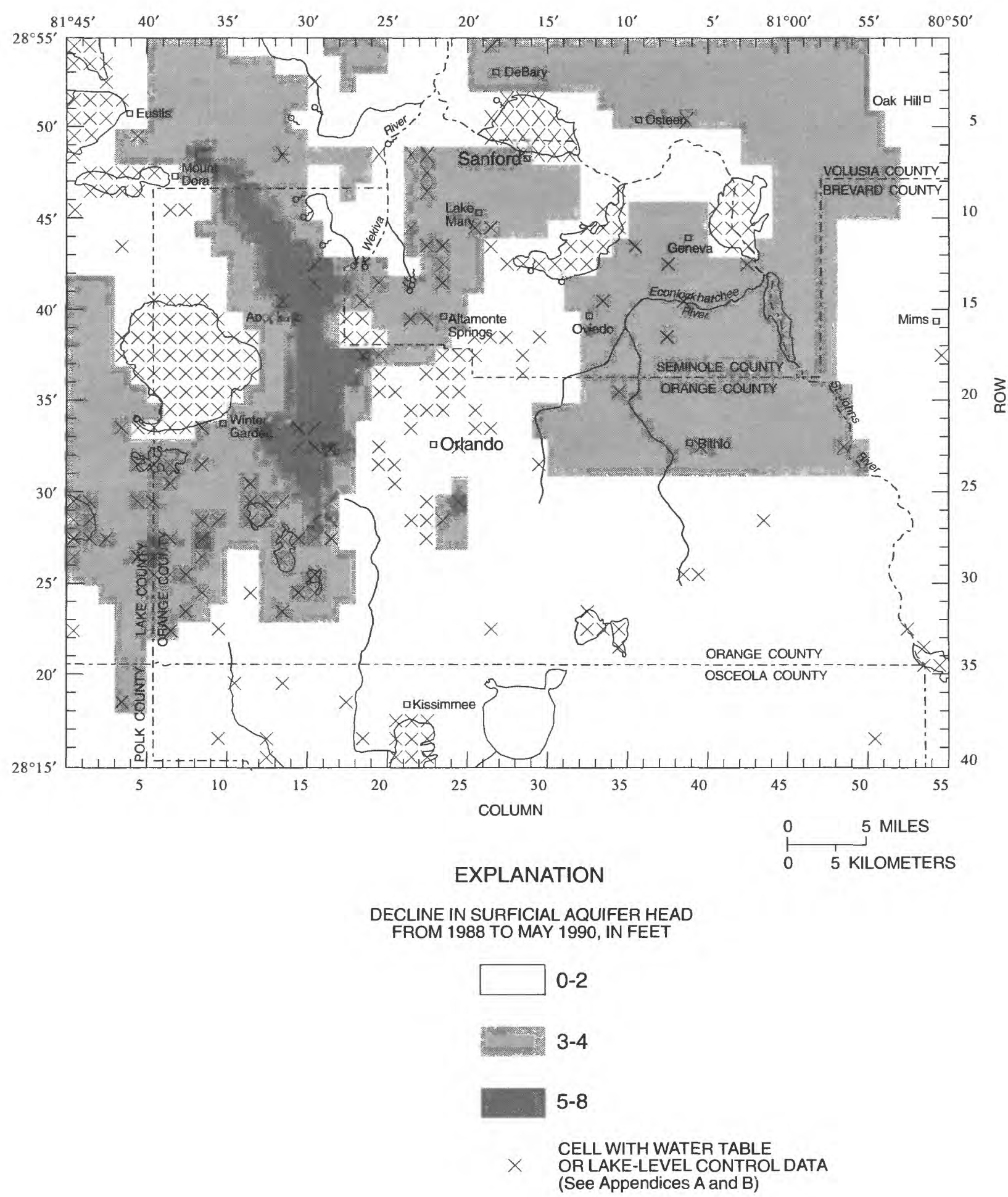

Figure 20. Estimated range of declines in surficial aquifer heads, average 1988 conditions to May 1990.

0.5 to $1.5 \mathrm{ft}$ higher than spring-pool altitudes measured in May 1990. Spring conductance values were calculated by dividing the average 1988 spring discharge by the difference in head between the spring pool and the average 1988 Upper Floridan aquifer head at the spring cell. Average 1988 Upper Floridan aquifer heads were estimated from potentiometric surface maps constructed in May and September 1988 
(Schiner, 1988; and Rodis, 1989; respectively). Included in this group are two flowing wells at the Wekiva Falls Resort in Lake County that discharged about $12 \mathrm{Mgal} / \mathrm{d}$ in 1988 .

Because drain conductance is a function of the cell dimensions, the calculated values apply only to the grid used for this study. In models with smaller grid spacings, the simulated head at the spring node would be lower than that simulated in this model because the head value would be averaged over a smaller cell area, closer to the spring. As a result, the head difference between the Upper Floridan aquifer and the spring pool would be reduced, requiring a greater drain conductance to produce the same discharge rate.

\section{River Stage and Bed Conductance}

Discharge from the Upper Floridan aquifer into the St. Johns River system was simulated with the MODFLOW River Package. The St. Johns River discharge area includes 88 model cells that cover the main stem of the river and adjoining lakes (fig. 20). The amount of water discharged from the aquifer into each model cell is computed by the Darcy equation (adapted from eq 63, McDonald \& Harbaugh, 1988) as:

$$
Q R I V=C R I V(H S-H R I V)
$$

where

$Q R I V$ is the discharge rate $\left(\mathrm{ft}^{3} / \mathrm{s}\right)$,

CRIV is the effective vertical conductance between the top of the riverbed and the underlying Upper Floridan aquifer $\left(\mathrm{ft}^{2} / \mathrm{s}\right)$,

$H S$ is the model-simulated head in the Upper Floridan aquifer at the river node ( $\mathrm{ft}$ ), and $H R I V$ is the altitude of the river stage ( $\mathrm{ft}$ ).

Data collected from USGS gaging stations (appendix B) were used to specify HRIV for both the steady-state and transient simulations. Initial values of CRIV were obtained from the RASA model and were adjusted during model calibration. The VCONT term between layers 1 and 2 in the BCF package was set equal to zero at each river cell to avoid redundancy in simulating vertical leakage from the Upper Floridan aquifer to the St. Johns River system.

\section{Ground-Water Withdrawals and Artificial Recharge}

About $305 \mathrm{Mgal} / \mathrm{d}$ of water was pumped from the Floridan aquifer system in 1988, $247 \mathrm{Mgal} / \mathrm{d}$ of which was pumped for municipal, industrial, and commercial purposes; $36 \mathrm{Mgal} / \mathrm{d}$ for agricultural irrigation; $10 \mathrm{Mgal} / \mathrm{d}$ for golf-course irrigation; and about $12 \mathrm{Mgal} / \mathrm{d}$ was discharged from abandoned flowing wells. About 75 percent of this water was withdrawn from the Upper Floridan aquifer (table 6). Pumpage in May 1990 totaled about $439 \mathrm{Mgal} / \mathrm{d}$, nearly 50 percent more than in 1988. The distributions of ground-water

Table 6. Water use during average 1988 conditions, January to May 1990, and projected 2010 conditions [All values are daily averages, in million gallons per day. Wet, drainage-well recharge rates equal to average 1988 rates; dry, drainage-well recharge rates equal to May 1990 rates]

\begin{tabular}{|c|c|c|c|c|c|c|c|c|c|}
\hline & \multirow[b]{2}{*}{ Aquifer } & \multirow[b]{2}{*}{ Water use category } & \multirow[b]{2}{*}{$\begin{array}{c}\text { Average } \\
1988\end{array}$} & \multicolumn{5}{|c|}{1990} & \multirow[b]{2}{*}{$\begin{array}{c}2010 \\
\text { Projected } \\
\text { pumpage }\end{array}$} \\
\hline & & & & 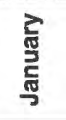 & 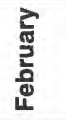 & 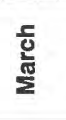 & $\overline{\bar{z}}$ & 网 & \\
\hline \multirow{6}{*}{ 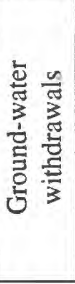 } & \multirow{5}{*}{$\begin{array}{l}\text { Upper } \\
\text { Floridan } \\
\text { aquifer }\end{array}$} & Municipal, industrial and & \multirow{6}{*}{$\begin{array}{r}172 \\
14 \\
22 \\
10 \\
12 \\
75\end{array}$} & 174 & 166 & 200 & 194 & 227 & 308 \\
\hline & & Agricultural-citrus irrigation & & 15 & 0 & 15 & 30 & 30 & 14 \\
\hline & & Agricultural-non-citrus irrigation & & 23 & 17 & 22 & 30 & 36 & 22 \\
\hline & & Golf course irrigation & & 6 & 3 & 12 & 15 & 20 & 10 \\
\hline & & Abandoned flowing wells & & 10 & 10 & 10 & 10 & 10 & 12 \\
\hline & $\begin{array}{c}\text { Lower Floridan } \\
\text { aquifer }\end{array}$ & Municipal supply & & 81 & 75 & 97 & 97 & 116 & 176 \\
\hline \multirow{4}{*}{ 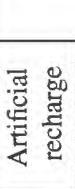 } & \multicolumn{2}{|r|}{ Total } & 305 & 309 & 271 & 356 & 376 & 439 & 542 \\
\hline & Upper Floridan & Orlando drainage wells & 30 & 30 & 30 & 30 & 22 & 15 & 30 (wet), 15 (dry) \\
\hline & aquifer & Reclaimed water application $^{2}$ & 18 & 17 & 16 & 17 & 17 & 16 & 18 \\
\hline & \multicolumn{2}{|r|}{ Total } & 48 & 47 & 46 & 47 & 39 & 31 & 48 (wet), 33 (dry) \\
\hline
\end{tabular}


withdrawals in 1988 from the Upper and Lower Floridan aquifers are shown on figures 21 and 22. A listing of individual municipal, industrial, and commercial water users, together with respective withdrawal rates

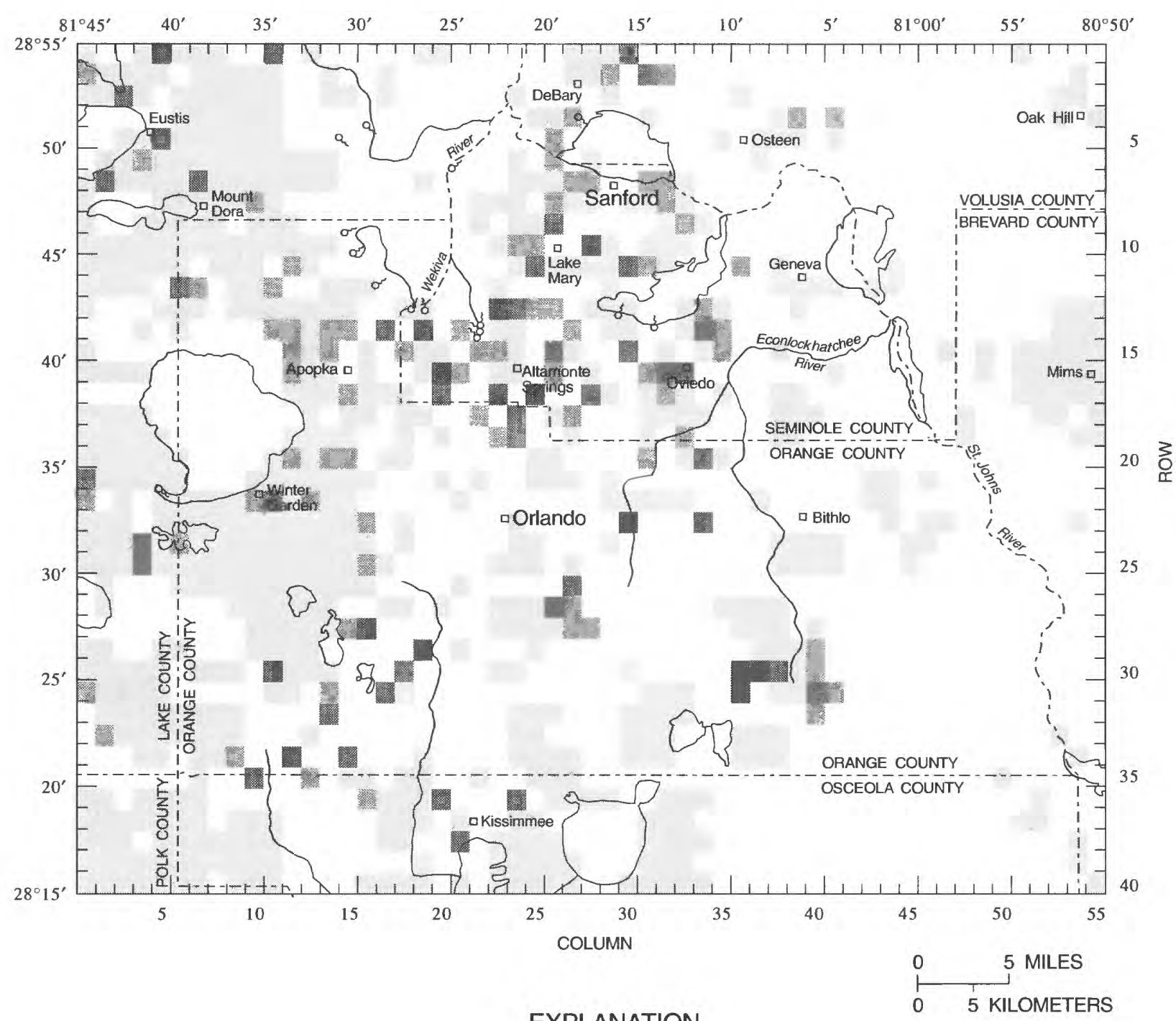

EXPLANATION

GROUND-WATER PUMPAGE, IN MILLIONS

OF GALLONS PER DAY (Mgal/d)

Less than 0.3

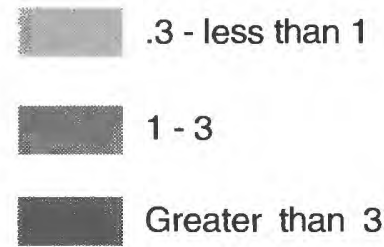

Total pumpage $=230 \mathrm{Mgal} / \mathrm{d}$

Figure 21. Distribution of average 1988 Upper Floridan aquifer pumpage. 


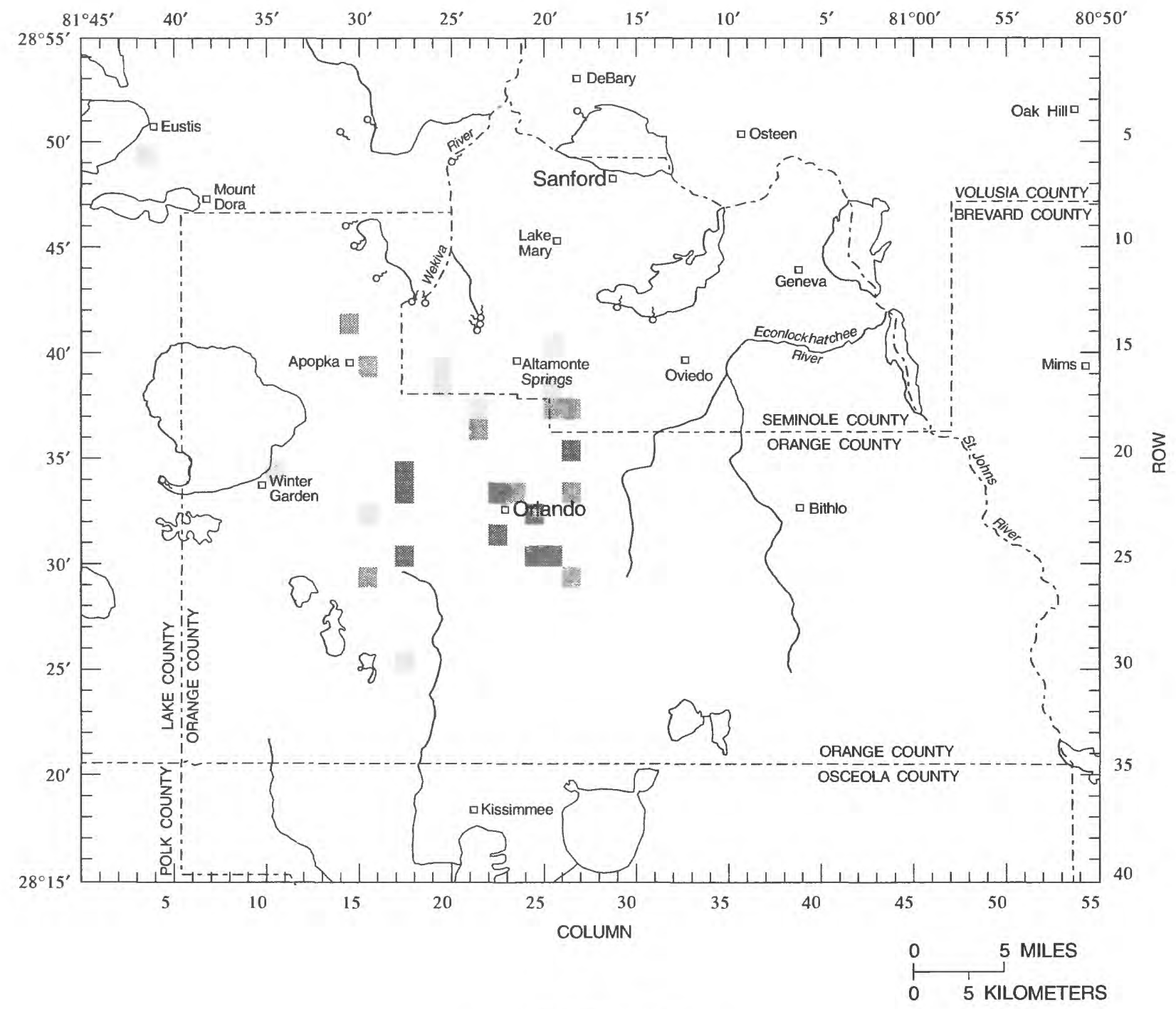

EXPLANATION

GROUND-WATER PUMPAGE, IN MILLIONS

OF GALLONS PER DAY (Mgal/d)

0 - less than 1

1 - less than 3

$3-9$

Total pumpage $=75 \mathrm{Mgal} / \mathrm{d}$

Figure 22. Distribution of average 1988 Lower Floridan aquifer pumpage.

for average 1988, December 1989 to May 1990, and projected 2010 conditions, is provided in appendix C.
Pumpage from the Floridan aquifer system was simulated with the MODFLOW Well Package. 
Ground-water withdrawal rates for municipal, industrial, and commercial users were obtained from monthly operating reports compiled by SJRWMD and SFWMD. Additional data were obtained from the Reedy Creek Improvement District (RCID), the Orlando Utilities Commission (OUC), the city of Cocoa, the Sanlando Utilities Corporation, and other municipalities. The monthly operating reports are based on metered readings and are considered accurate. Average daily well-field discharge rates were calculated from these data for 1988 and for each of the months from December 1989 to May 1990. Permitted withdrawal rates were assigned to several industrial users where metered data were not available. The locations and penetration depths of individual wells in each well field were provided by FDEP, SJRWMD, SFWMD, and municipalities.

Assumptions were made to apportion total pumpage between individual wells and between the Upper and Lower Floridan aquifers where data were lacking. At well fields containing multiple wells, the average daily well-field discharge rate was divided by the number of wells to obtain an average pumping rate per well. The error associated with this approach probably is negligible because individual wells that comprise most well fields are located in the same model cell. Discharge from wells that penetrate both the Upper and Lower Floridan aquifers was divided equally between the two aquifers.

Ground-water withdrawals required to irrigate citrus, non-citrus crops, and golf courses generally are not metered but, for 1988, were estimated at 14,22 , and $10 \mathrm{Mgal} / \mathrm{d}$, respectively (table 6). These withdrawals increased during the drought period and peaked at about 30, 36, and $20 \mathrm{Mgal} / \mathrm{d}$ in May 1990. The pumping rates shown in table 6 were calculated by multiplying the crop or golf-course acreage identified in each cell by an estimated irrigation rate. Citrus-farm locations and acreages were obtained from the Florida Agricultural Statistics Service in Orlando, Florida. Cells with less than 5 acres of citrus or citrus farms irrigated with reclaimed water were not included in these compilations. Acreages for noncitrus crops (vegetables, nurseries, sod, ferns, and improved pasture) were obtained from Consumptive Use Permit (CUP) files provided by SJRWMD and SFWMD. Acreage related to permits issued after April 1988 was omitted from the 1988 compilations; acreage described in permits issued after January 1990 was omitted from the transient period compilations. Per- mits issued for less than 5 acres were also omitted. Ground-water withdrawals were assumed negligible for users whose permits indicated that ground water was used soley to backup a primary surface-water source. Irrigated acreage was estimated for each of 53 golf courses by multiplying the number of holes at the course by 4.2 acres, the average acreage per hole reported by Duerr and Trommer (1982, p. 40).

Ground-water withdrawals were assumed negligible at golf courses irrigated with reclaimed water or surface water.

Irrigation rates estimated for average annual 1988 conditions and monthly from January to May 1990 are listed in table 7 . The citrus irrigation rate in 1988 was estimated at $10 \mathrm{in} / \mathrm{yr}$, based on studies in which SJRWMD (Singleton, 1988) and the USGS (Duerr and Trommer, 1982) recorded metered irrigation rates at selected benchmark farms over a period of several years. Irrigation rates estimated for January to May 1990 ranged from 0 in. in February to 2 in. in May (Bruce Florence, SJRWMD, written commun., 1992). For the non-citrus crops and golf courses, irrigation rates for 1988 were obtained from Florence (1990), whereas monthly rates for the January to May 1990 drought period were provided by SJRWMD or taken from benchmark data (Singleton, 1988; Duerr and Trommer, 1982). Irrigation rates for vegetable farms were obtained from CUP files and assumed constant for both simulated periods. The irrigation rates estimated in this study for both citrus and non-citrus crops probably are within plus or minus 50 percent of actual rates.

Table 7. Estimated application rates for agricultural irrigation for average 1988 and January to May 1990

[Application rates are in acre-inches. Estimated application rates for all but vegetables and fruits taken from Florence (1990); Duerr and Trommer (1982); and Singleton (1988)]

\begin{tabular}{|c|c|c|c|c|c|c|c|}
\hline \multirow[b]{2}{*}{ Crop } & \multicolumn{2}{|c|}{1988} & \multicolumn{5}{|c|}{1990} \\
\hline & $\begin{array}{l}\text { Total } \\
\text { for } \\
\text { year }\end{array}$ & $\begin{array}{l}\text { Average } \\
\text { monthly }\end{array}$ & 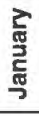 & 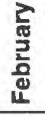 & 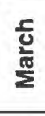 & 䇏 & స్ \\
\hline Citrus & 10 & 0.8 & 1 & 0 & 1 & 2 & 2 \\
\hline Golf course & 40 & 3.3 & 2 & 1 & 4 & 5 & 7 \\
\hline Nursery & 90 & 7.5 & 7 & 4 & 8 & 12 & 18 \\
\hline Ferns & 60 & 5.0 & 6 & 3 & 4 & 4 & 5 \\
\hline Landscape & 30 & 2.5 & 2 & 1 & 3 & 4 & 5 \\
\hline Sod, Turf & 30 & 2.5 & 2 & 1 & 3 & 4 & 5 \\
\hline Pasture & 6 & 0.5 & 1 & 0 & 0 & 1 & 1 \\
\hline $\begin{array}{l}\text { Vegetables } \\
\& \text { fruits }\end{array}$ & \multicolumn{2}{|c|}{ as permitted ${ }^{1}$} & \multicolumn{5}{|c|}{ as permitted ${ }^{1}$} \\
\hline
\end{tabular}

${ }^{1}$ Application rates as permitted for individual crop farms by the St. Johns River or South Florida Water Management District (single rate used for both 1988 and 1990 simulations). 
Recharge to the Upper Floridan aquifer from Orlando drainage wells and reclaimed water was simulated with the MODFLOW Recharge package.

Recharge rates measured at the Lake Underhill and Lake Killarney drainage wells ( 2.1 and $2.5 \mathrm{Mgal} / \mathrm{d}$, respectively) were applied to the appropriate cells and were not adjusted during model calibration. The remaining $25.4 \mathrm{Mgal} / \mathrm{d}$ of recharge was evenly distributed among the other cells and adjusted during model calibration to better replicate Upper Floridan aquifer heads in the Orlando area. Recharge rates at individual wells are largely unknown and the calibrated rates shown in figure 23 represent the aggregated totals for the wells grouped in respective model cells. Higher

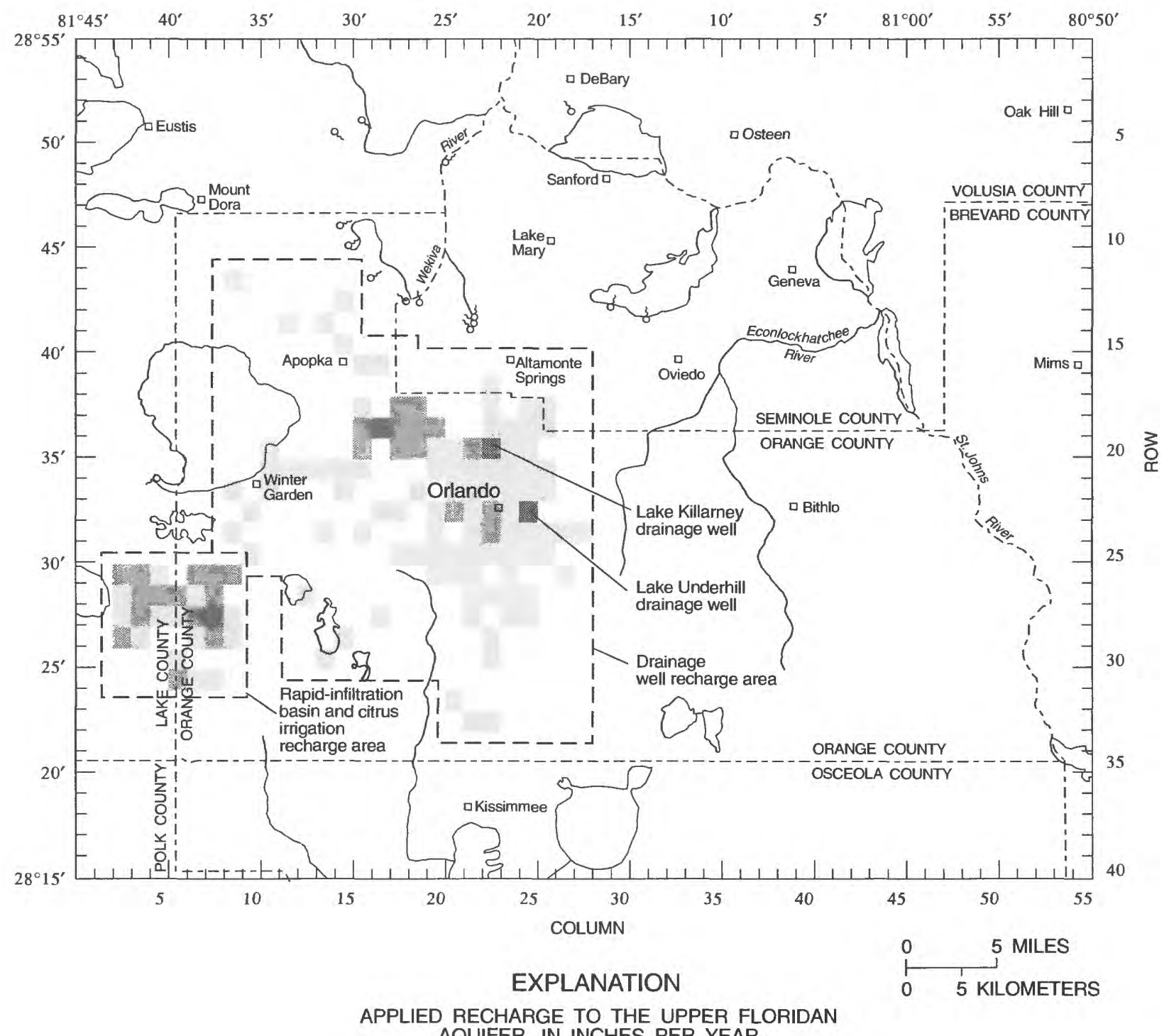

$1-10$

$11-30$

$31-50$

Figure 23. Distribution of recharge to the Upper Floridan aquifer from drainage wells (calibrated) and rapid-infiltration basins (measured) for average 1988 steady-state conditions. 
rates of recharge were applied to wells that control lake levels and continuously receive recharge; lower rates were applied to wells that receive intermittent stormwater runoff. Recharge rates applied to the model for the transient simulations were estimated by decreasing the calibrated 1988 recharge rates in proportion to the decreased inflows observed at the Lake Underhill and Lake Killarney drainage wells during this period. Observed inflows to the Lake Underhill and Lake Killarney wells in May 1990 were only about 50 percent of 1988 rates.

The distribution and rates of reclaimed water applied to the Conserv II project areas by land application were provided by Metcalf \& Eddy Services, Inc. The actual percentage of applied water that recharges the Upper Floridan aquifer is unknown, but probably exceeds 50 percent of the total. Recharge rates used in this study and shown in figure 23 were calculated by multiplying the land-application rates by 0.8 , a factor representative of irrigation efficiencies (Vince Singleton, SJRWMD, oral commun., 1992). Based on these calculations, about $18 \mathrm{Mgal} / \mathrm{d}$ of reclaimed water was assumed to recharge the Upper Floridan aquifer in 1988. Assumed recharge rates from January to May 1990 ranged from about 20 to $22 \mathrm{Mgal} / \mathrm{d}$.

\section{Calibration and Results}

The model was calibrated by adjusting model-parameter values - within reasonable ranges - until an acceptable match was achieved between model-simulated and measured Upper Floridan aquifer heads and spring flow. Specific calibration criteria included the (1) steady-state water levels measured in 142 Upper Floridan aquifer monitoring wells in 1988; (2) the discharge rates measured at 15 Upper Floridan aquifer springs in 1988 and in May 1990;

(3) the estimated spring flow and Upper Floridan aquifer potentiometric surface as it existed prior to extensive ground-water development; (4) declines in Upper Floridan aquifer water levels measured in 12 wells equipped with continuous water-level recorders from January to May 1990; and (5) drawdowns measured in 134 Upper Floridan aquifer monitoring wells between 1988 and May 1990. Parameters adjusted during model calibration included both Upper and Lower Floridan aquifer transmissivity, intermediate confining unit leakance, middle semiconfining unit leakance, and drain and river conductances. Drainage-well recharge rates were also adjusted during model calibration.

Parameter adjustments were guided by several criteria. The results from numerous aquifer tests were used as minima to bracket a range of values for the transmissivity of the Upper and Lower Floridan aquifers. The assigned leakance of the intermediate confining unit and, to a lesser extent, of the middle semiconfining unit, were also based on aquifer-test results. Highest intermediate confining unit leakance generally was assigned to cells where the confining unit is thin or where the topography is characterized by numerous karst features. Lowest leakances correspond to areas where the confining unit is thickest. Calibrated leakance and Upper Floridan aquifer transmissivity arrays were further evaluated by comparing, for general consistency, simulated recharge rates to the Upper Floridan aquifer from the surficial aquifer system to the recharge rates mapped in figure 7.

Calibrated recharge rates for 1988 were not allowed to exceed $21 \mathrm{in} / \mathrm{yr}$, the difference between long-term average annual precipitation and an assumed minimum ET of $30 \mathrm{in} / \mathrm{yr}$ (Tibbals, 1990). Additional adjustments were made to the Upper Floridan aquifer transmissivity and intermediate confining unit leakance arrays during the transient simulations to better simulate declines in Upper Floridan aquifer heads measured in monitoring wells.

\section{Steady-State Simulations}

The Upper Floridan aquifer potentiometric surface simulated by the calibrated model prior to development compares favorably with water levels measured in the early 1930's (fig. 24). Similarly, the simulated 1988 steady-state surface is consistent with average 1988 water levels measured in 142 monitoring wells (fig. 25). For predevelopment conditions, water levels measured near the city of Orlando are higher than simulated heads, probably because the predevelopment model did not account for recharge to the Upper Floridan aquifer from numerous Orlando drainage wells. As many as 100 to 200 of these wells had been constructed in the Orlando area by the early 1940's (Unklesbay, 1944). In north-central Seminole County, simulated predevelopment heads were higher than observed heads, possibly because the model did not account for Upper Floridan aquifer discharge from numerous flowing wells used to irrigate crops in the 1930's. 


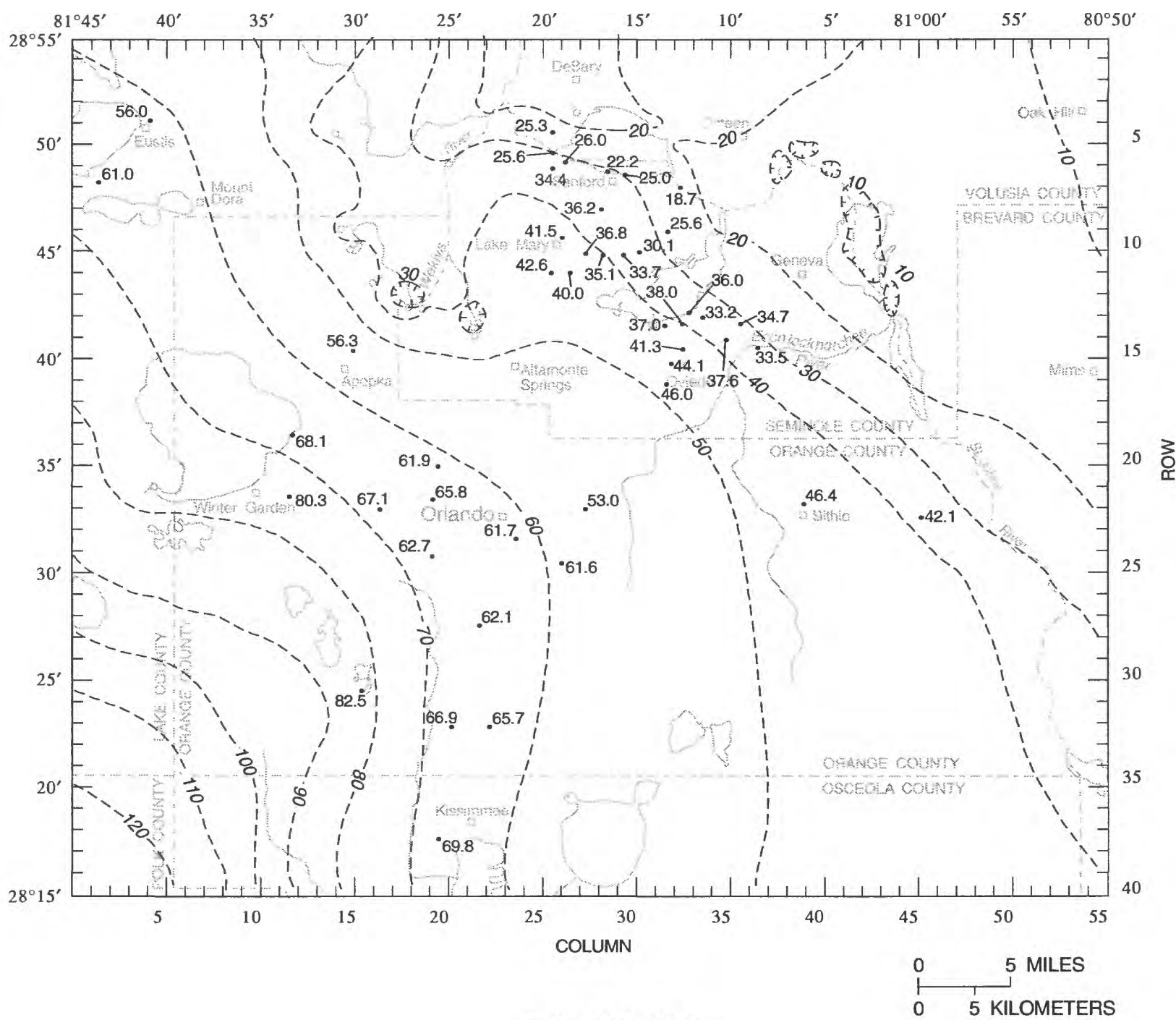

EXPLANATION

40 - - - POTENTIOMETRIC CONTOUR OF UPPER FLORIDAN AQUIFER--

Derived from computer model simulation of predevelopment heads.

Shows altitude of potentiometric surface. Hachures indicate

depressions. Contour interval 10 feet. Datum is sea level

69.8. WELL USED TO MEASURE UPPER FLORIDAN AQUIFER HEAD --

Number is head, in feet above mean sea level (from figure 8).

Well locations and descriptions are arranged by model row

and column number in Appendix $\mathrm{A}$

Figure 24. Simulated Upper Floridan aquifer potentiometric surface for predevelopment steady-state conditions and water levels measured at selected Upper Floridan aquifer monitoring wells in the early 1930's.

The simulated 1988 Lower Floridan aquifer potentiometric surface is a subdued reflection of the Upper Floridan aquifer potentiometric surface (fig. 26). Water levels measured in five Lower Floridan aquifer monitoring wells in the late 1980's and early 1990 's generally are consistent with simulated con- tours. Simulated Lower Floridan aquifer heads generally are lower than Upper Floridan aquifer heads in recharge areas and higher than Upper Floridan aquifer heads in discharge areas. These results are consistent with the conceptualized model discussed in the previous section. Simulated Lower Floridan aquifer heads 


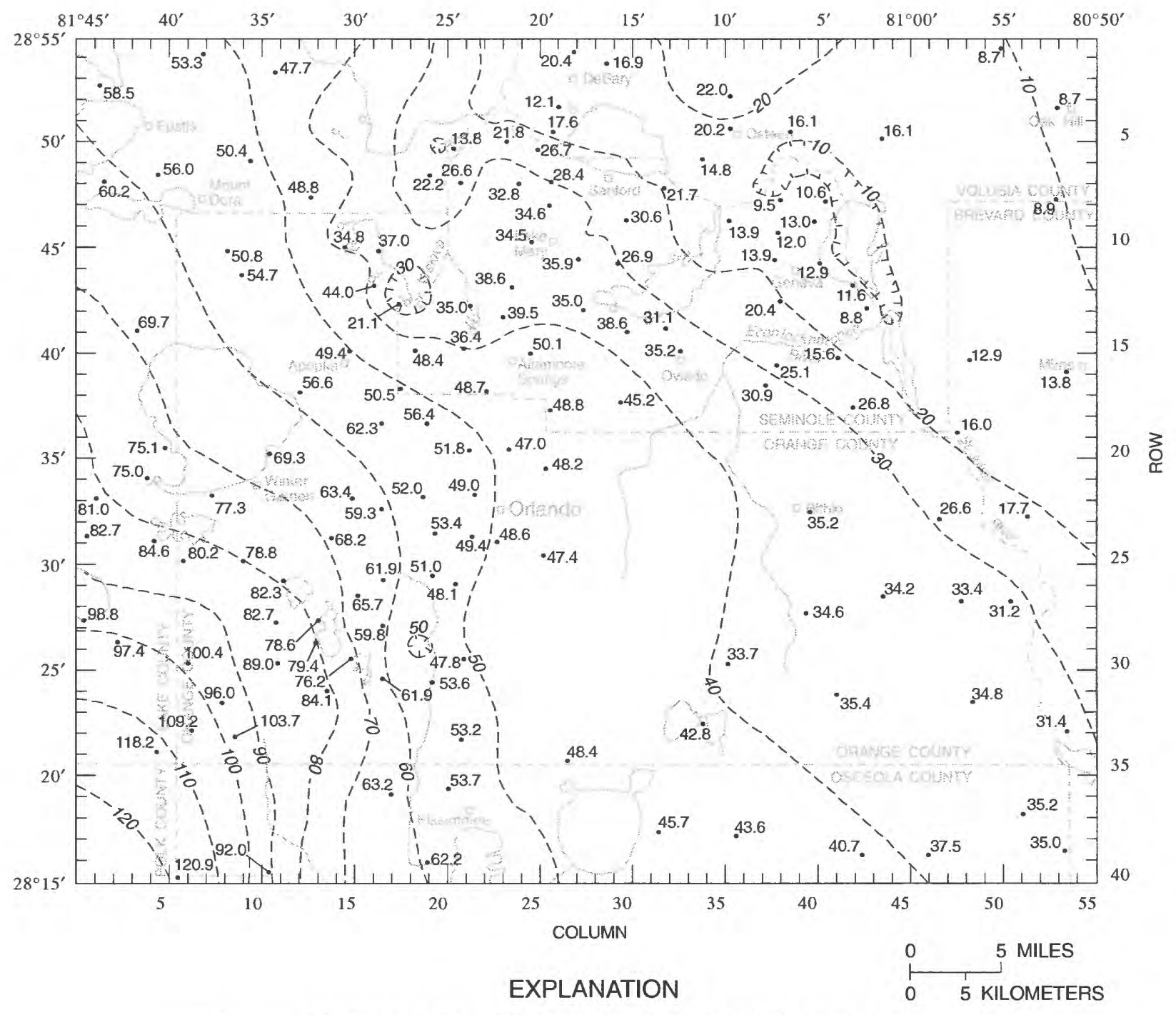

-- $60---$ POTENTIOMETRIC CONTOUR OF UPPER FLORIDAN AQUIFER--

Derived from computer model simulation of average 1988

heads. Shows altitude of potentiometric surface.

Hachures indicate depressions. Contour interval 10 feet.

Datum is sea level

"43.6 WELL USED TO MEASURE AVERAGE 1988 UPPER FLORIDAN AQUIFER HEAD Number is head, in feet above mean sea level (from figure 10). Well located by column and row and described in Appendix A

Figure 25. Simulated Upper Floridan aquifer potentiometric surface for average 1988 steady-state conditions and water levels measured at Upper Floridan aquifer monitoring wells.

in central Orange County are 1 to $3 \mathrm{ft}$ lower than simulated Upper Floridan aquifer heads.

Upper Floridan aquifer heads simulated in 1988 are within $2 \mathrm{ft}$ of measured heads in 101 of 142 monitoring wells (fig. 27). The average absolute error, calculated as the average of the absolute values of the differences between measured and simulated water levels, is $1.8 \mathrm{ft}$. The average error (algebraic sum of the differences divided by the number of observations) is $0.12 \mathrm{ft}$, indicating little bias in simulated results.

Simulated and observed spring flow for both predevelopment and average 1988 steady-state conditions are listed in table 8 . Predevelopment discharge rates simulated by the model totaled $356 \mathrm{ft}^{3} / \mathrm{s} \mathrm{com-}$ 


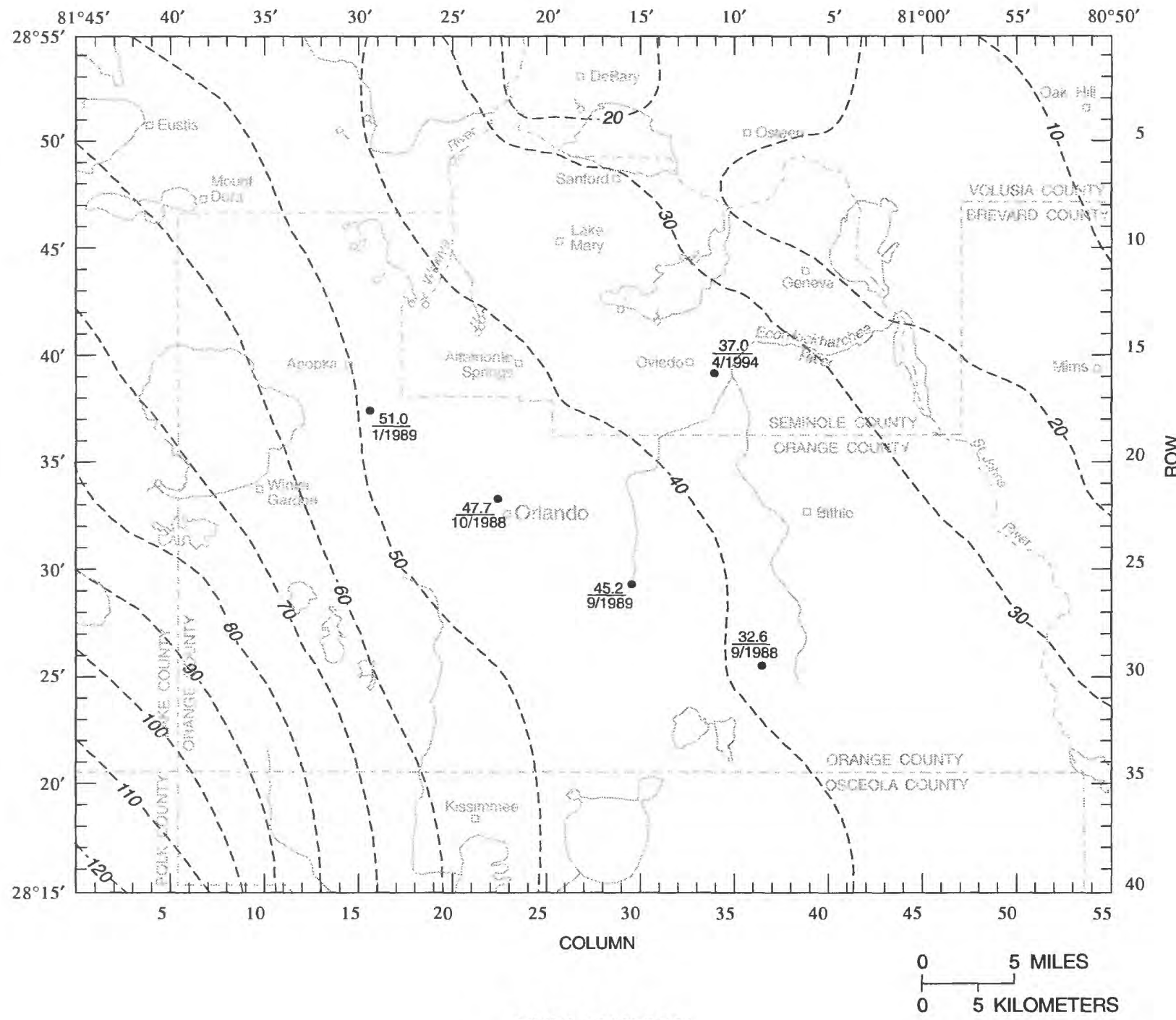

EXPLANATION

--50-- POTENTIOMETRIC CONTOUR -- Contours derived from computer-model simulation of Lower Floridan aquifer heads, average 1988 conditions. Contour interval is 10 feet. Datum is sea level

$\frac{45.2}{9 / 1989}$ - WELL USED TO MEASURE LOWER FLORIDAN AQUIFER HEAD -Top number is head, in feet above mean sea level.

Bottom number is month and year in which measurement was recorded. Well locations and descriptions are arranged by model row and column

Figure 26. Simulated Lower Floridan aquifer potentiometric surface for average 1988 steady-state conditions and water levels measured at selected Lower Floridan aquifer monitoring wells.

pared to an independently estimated rate of about $360 \mathrm{ft}^{3} / \mathrm{s}$. Simulated discharge rates in 1988 totaled $306 \mathrm{ft}^{3} / \mathrm{s}$, equal to that measured in 1988 . Discharge rates simulated at the largest springs (Wekiva, Apopka, Rock, the Sanlando group, and Seminole) were within 3 percent of measured values. The simulated reduction in spring discharge between predevelopment and 1988 conditions totaled $50 \mathrm{ft}^{3} / \mathrm{s}$ compared to a difference of $54 \mathrm{ft}^{3} / \mathrm{s}$ between the estimated predevelopment and the measured 1988 spring discharges.

Water budgets simulated by the model and shown in figure 28 indicate that recharge from the surficial aquifer system was the single largest contributor of water to the Upper Floridan aquifer during pre- 


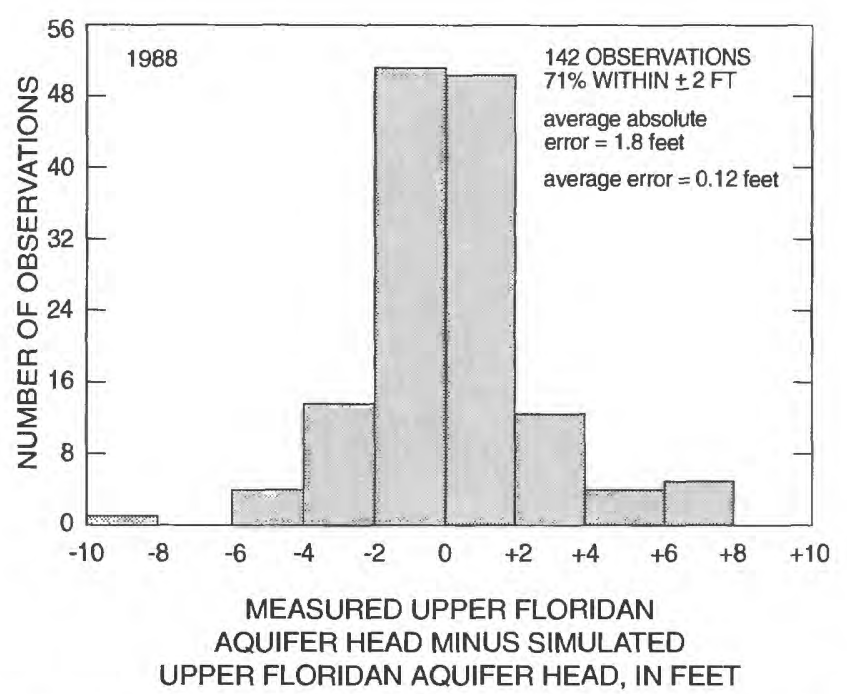

Figure 27. Differences between simulated and measured water levels in the Upper Floridan aquifer for average 1988 steady-state conditions.

development and 1988 conditions (540 and $771 \mathrm{ft}^{3} / \mathrm{s}$, respectively). Smaller amounts of water were contributed by lateral (boundary) inflow ( 69 and $79 \mathrm{ft}^{3} / \mathrm{s}$, respectively). Discharge from the aquifer by spring flow totaled 356 and $306 \mathrm{ft}^{3} / \mathrm{s}$ for predevelopment and average 1988 conditions, respectively. Smaller amounts of discharge occurred by diffuse upward leakage to the surficial aquifer system (108 and $64 \mathrm{ft}^{3} / \mathrm{s}$, respectively) and St. Johns River (96 and $78 \mathrm{ft}^{3} / \mathrm{s}$, respectively), and by lateral outflow across model boundaries ( 65 and $55 \mathrm{ft}^{3} / \mathrm{s}$, respectively). Well discharge in 1988 totaled $356 \mathrm{ft}^{3} / \mathrm{s}$.

About half $\left(231 \mathrm{ft}^{3} / \mathrm{s}\right)$ of the $473 \mathrm{ft}^{3} / \mathrm{s}$ of water discharged by wells from the Floridan aquifer system in 1988 was accounted for by increased recharge from the surficial aquifer system. The possible sources of this increased recharge include excess 1988 rainfall (56 in. as compared to 51 in., the long-term annual average assumed for predevelopment conditions), captured evapotranspiration, and reduced surface runoff. Much of the increased surficial-aquifer recharge occurred across areas of west Orange, east Lake, west Seminole, and southwest Volusia Counties, where the intermediate confining unit is thin or is breached by numerous sinkholes. The balance of pumpage was accounted for by recharge from drainage wells and reclaimed water $\left(75 \mathrm{ft}^{3} / \mathrm{s}\right)$ and by reductions in spring flow $\left(50 \mathrm{ft}^{3} / \mathrm{s}\right)$, diffuse upward leakage $\left(44 \mathrm{ft}^{3} / \mathrm{s}\right)$, lat-

Table 8. Measured or estimated discharge and simulated discharge from selected Upper Floridan aquifer springs during predevelopment, average 1988, and May 25, 1990 conditions

[All discharge values in cubic feet per second. --, spring discharge not measured in May 1990]

\begin{tabular}{|c|c|c|c|c|c|c|}
\hline \multirow[t]{2}{*}{ Name of spring } & \multicolumn{2}{|c|}{$\begin{array}{c}\text { Predevelopment } \\
\text { steady-state conditions }\end{array}$} & \multicolumn{2}{|c|}{$\begin{array}{c}1988 \text { average steady-state } \\
\text { conditions }\end{array}$} & \multicolumn{2}{|c|}{$\begin{array}{c}\text { End of transient drought } \\
\text { period May 25, } 1990\end{array}$} \\
\hline & Estimated & Simulated & Measured $^{\mathrm{a}}$ & Simulated & Measured $^{\mathrm{a}}$ & Simulated \\
\hline Wekiva & 80 & 80 & 69 & 69 & 52 & 56 \\
\hline Apopka & 70 & 69 & 61 & 62 & -- & 51 \\
\hline Rock & 70 & 63 & 58 & 58 & 46 & 51 \\
\hline Sanlando, Palm, and Starbuck & 50 & 53 & 41 & 40 & 28 & 29 \\
\hline Seminole & 40 & 45 & 39 & 38 & 34 & 30 \\
\hline Messant & 20 & 17 & 14 & 16 & 12 & 14 \\
\hline Island & 10 & 9.1 & 6 & 7.2 & -- & 6.5 \\
\hline Gemini & 10 & 8.1 & 8 & 6.7 & - & 5.7 \\
\hline Miami & 6 & 6.5 & 5 & 4.8 & 4 & 3.6 \\
\hline Witherington & 2 & 1.2 & 1 & 1.0 & - & 0.8 \\
\hline Clifton & 2 & 1.9 & 2 & 1.5 & -- & 1.2 \\
\hline Sulphur & 2 & 1.3 & 1 & 1.1 & -- & 0.9 \\
\hline Lake Jesup & 1 & 1.0 & 1 & 0.8 & -- & 0.7 \\
\hline TOTAL: & $360^{d}$ & 356 & 306 & 306 & ${ }_{(176)^{b}}^{b}$ & $\begin{array}{l}250 \\
(184)^{c}\end{array}$ \\
\hline
\end{tabular}

${ }^{\text {a }}$ Spring-discharge measurements typically are subject to \pm 10 percent error, except for submerged Apopka and Island Springs, which are subject to measurement errors of 25 percent or greater.

${ }^{\mathrm{b}}$ Total discharge measured from the eight springs in May 1990.

${ }^{c}$ Total discharge simulated from the eight measured springs in May 1990.

${ }^{\mathrm{d}}$ Rounded to two significant figures. 


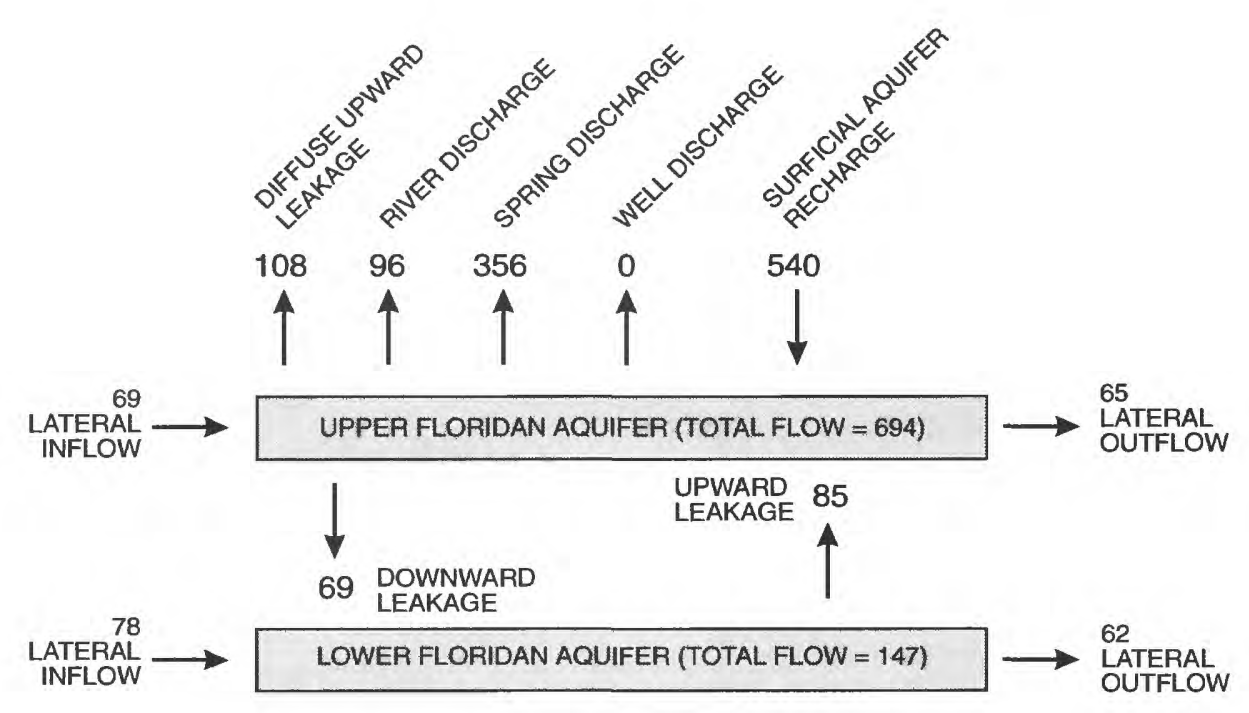

PREDEVELOPMENT STEADY-STATE CONDITIONS

(All values in cubic feet per second)

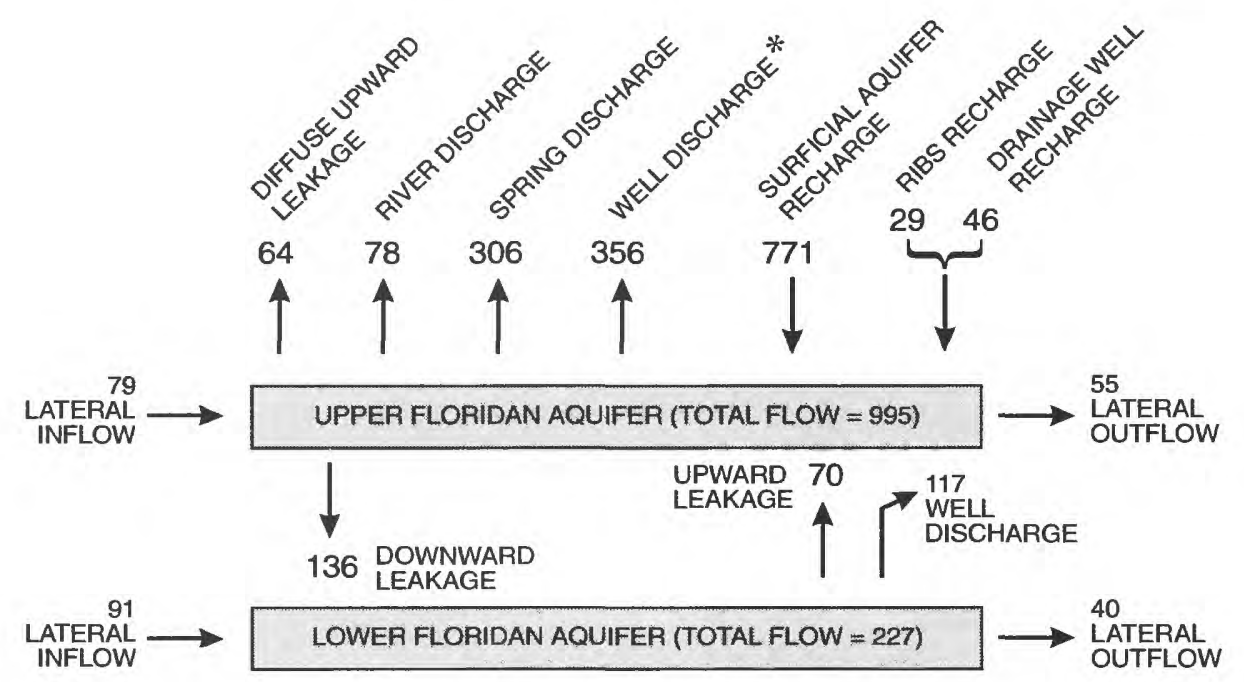

AVERAGE 1988 STEADY-STATE CONDITIONS

(All values in cubic feet per second)

*WELL DISCHARGE INCLUDES
17 CUBIC FEET PER SECOND OF UPPER
FLORIDAN AQUIFER DISCHARGE FROM
FLOWING WELLS AT WEKIVA FALLS RESORT.

Figure 28. Simulated hydrologic budgets for steady-state predevelopment and average 1988 conditions.

eral outflow ( $32 \mathrm{ft}^{3} / \mathrm{s}$ for both aquifers) and river discharge $\left(18 \mathrm{ft}^{3} / \mathrm{s}\right)$. A relatively small increase in lateral inflow ( $23 \mathrm{ft}^{3} / \mathrm{s}$ total for both aquifers) was induced by 1988 pumpage (fig. 28).

The net flow rate of water exchanged between the Upper and Lower Floridan aquifers prior to devel- opment was relatively small $\left(16 \mathrm{ft}^{3} / \mathrm{s}\right)$ and moved upward from the Lower to the Upper Floridan aquifer. In 1988 , the net flow rate increased to $66 \mathrm{ft}^{3} / \mathrm{s}$ and moved from the Upper Floridan aquifer to the Lower Floridan aquifer. The reversal and increase in the net flow rate can be attributed to the drawdowns induced 
in the Lower Floridan aquifer by 1988 pumpage and from mounding of the Upper Floridan potentiometric surface by recharge from the Orlando drainage wells.

\section{Transient Simulation}

For the transient simulation, the January to May 1990 drought period was divided into five stress periods, each corresponding to a month. Each stress period was further subdivided into 60 time steps to improve the temporal resolution of the simulated heads. Starting heads for the Upper and Lower Floridan aquifers were determined from a steady-state simulation of the flow system using December 1989 pumping rates. Specified GHB heads, surficial aquifer heads, and pumping rates for each of the five stress periods were assigned as previously discussed. Surficial aquifer heads were recalculated for each time step by linear interpolation between heads specified at the middle of respective stress periods. The interpolation scheme developed by Leake and others (1994) was used for these calculations. Simulations were completed for each of three storage coefficients $\left(1 \times 10^{-4}, 5 \times 10^{-4}\right.$, and $1 \times 10^{-3}$ ) that bracket the range of values referenced in previous aquifer tests (Szell, 1993). The lowest of these three values approximates the theoretical minimum storage coefficient of $8 \times 10^{-5}$ calculated for the Upper Floridan aquifer using equation 1, whereas the median value of $5 \times 10^{-4}$ equals the theoretical minimum value calculated for the Lower Floridan aquifer.

Water-level declines measured in the Upper Floridan aquifer from January to May 1990 generally are well simulated by the model (figs. 29-32). At well OR-47 (fig. 30), where the simulated drawdown is appreciably higher than the observed drawdown, recharge through numerous drainage wells in the area may not have been entirely accounted for by the recharge rates assigned to the model for the final stress period. The short-term fluctuations induced by variations in daily pumpage from nearby well fields could not be simulated by the model since the applied pumpage was constant across each stress period (only average monthly pumping rates were available for most users). The abrupt change in head simulated at the beginning of each stress period is attributed to the corresponding change in pumpage imposed at the beginning of each period.

Simulated water levels generally were insensitive to changes in storage coefficient for most of the transient period. In May 1990, however, when changes in pumpage, direct recharge, and surficial aquifer heads were greatest, simulated water-level declines were more sensitive to changes in storage coefficient, particularly at the Cocoa A, Cocoa P, Bithlo, OR-47, and Sea World monitoring wells that are located near high-capacity well fields. Water released from storage accounted for less than 5 percent of the total simulated inflow to the aquifer system during the first 10 days of the May stress period (using the median storage coefficient of $5 \times 10^{-4}$ ) but represented about 80 percent of the change in inflow during this 10-day period.

A storage coefficient of $1 \times 10^{-3}$ provided the best match between simulated and measured water-level declines. These results are similar to those reported by Tibbals (1990) and may account for the combined effects of water released from storage in both the Upper Floridan aquifer and the overlying intermediate confining unit. Because changes in Upper Floridan aquifer heads are generally insensitive to the storage coefficient, the model was not areally calibrated for this parameter. Additionally, the high transmissivity and low storativity of the Floridan aquifer system result in a large diffusivity (T/S). Thus, the aquifer probably equilibrates rapidly to changes in stress or stress distribution, further minimizing the importance of transient analyses.

The Upper Floridan aquifer potentiometric surface simulated by the model at the end of the transient period (May 25, 1990) is consistent with water levels measured in 145 monitoring wells during the third week in May (fig. 33). Relative to 1988 conditions, the simulated May 1990 potentiometric surface is affected by a 40 percent increase in pumpage from the Floridan aquifer system and by declines in surficial aquifer heads (fig. 19). The average absolute error calculated between measured and simulated water levels is $1.7 \mathrm{ft}$, with an average error of $0.13 \mathrm{ft}$. Drawdowns measured in 134 monitoring wells common to both 1988 and May 1990 data-collection periods ranged from 6 to $10 \mathrm{ft}$ in central Orange, southwest Seminole, and north-central Osceola Counties, and were less than $4 \mathrm{ft}$ across the rest of the study area (fig. 33). Drawdowns simulated by the model are within plus or minus 25 percent of measured drawdowns at 78 of the 134 monitoring wells, and within plus or minus 50 percent of drawdowns measured in 128 of the 134 wells (fig. 34).

Drawdowns simulated in the less populated areas of northwest Orange and east Lake Counties generally were less than measured drawdowns. Differences between simulated and measured drawdowns in 

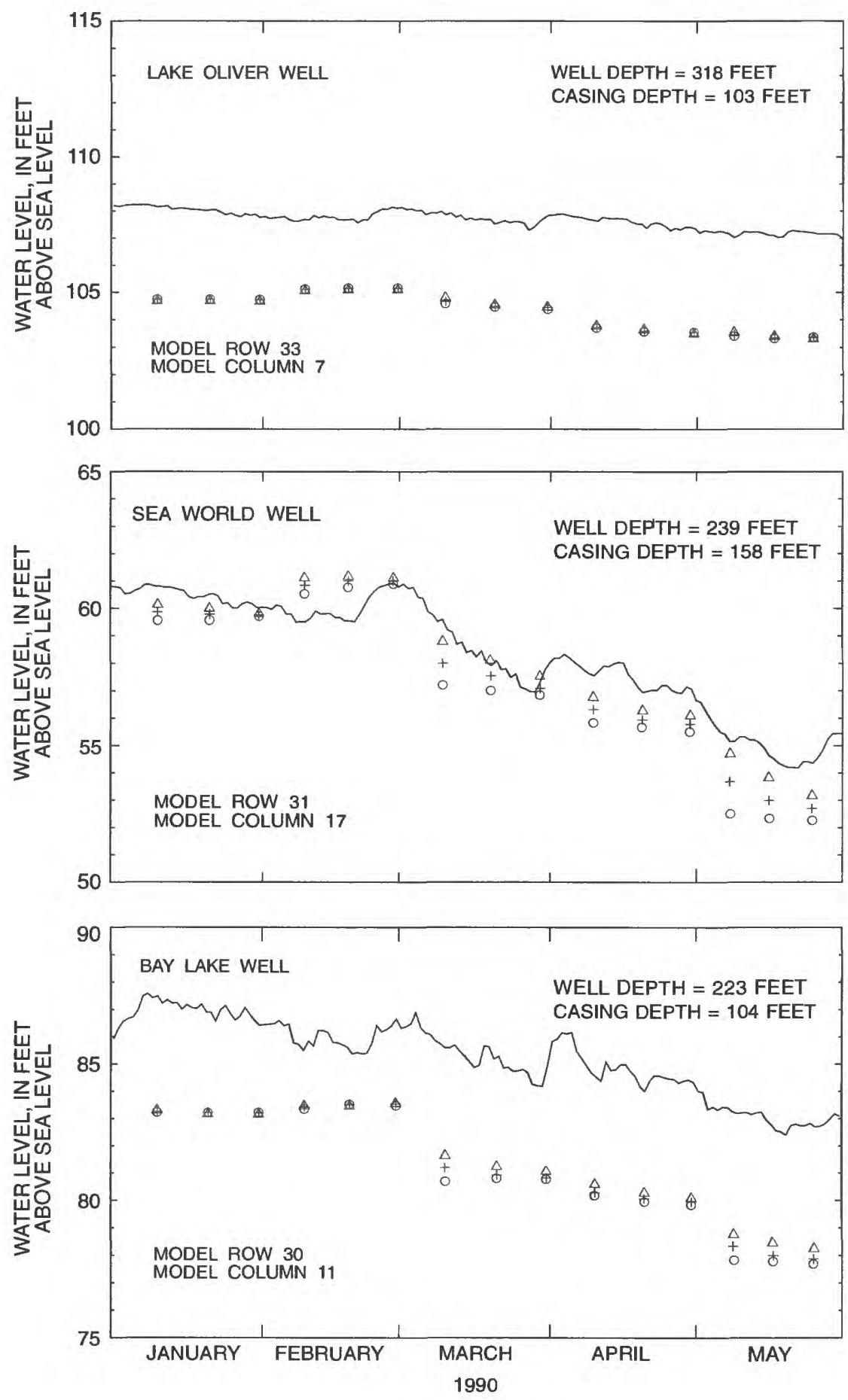

\section{EXPLANATION}

— MEASURED WATER LEVEL, CONTINUOUS

$\times$ MEASURED WATER LEVEL, DISCRETE

SIMULATED WATER LEVEL FOR A STORAGE COEFFICIENT OF:

$\triangle \quad 1 \times 10^{-3}$
$+\quad 5 \times 10^{-4}$
$-\quad 1 \times 10^{-4}$

Figure 29. Observed and simulated water levels in selected Upper Floridan aquifer monitoring wells, January 1 to May 25, 1990. 

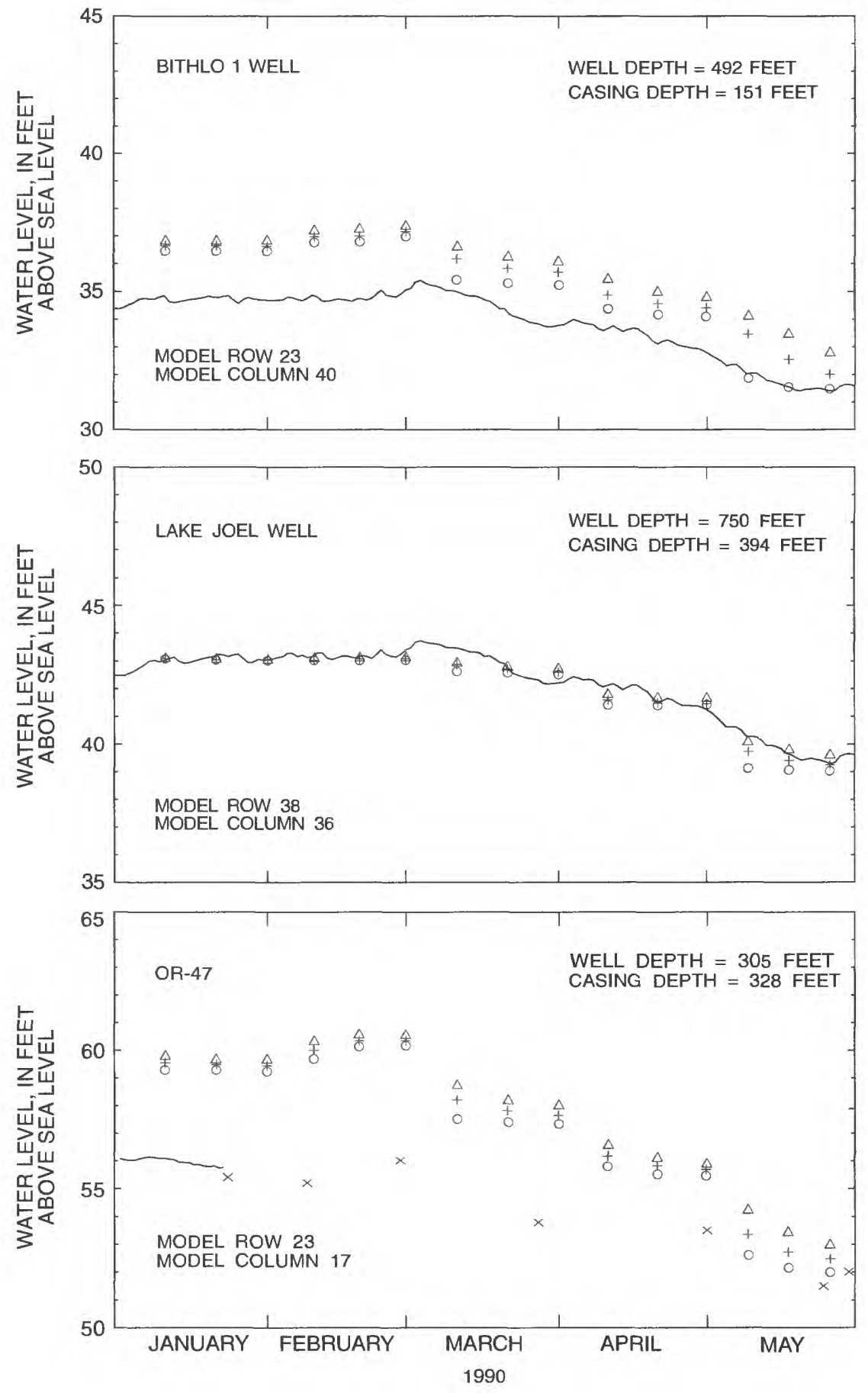

EXPLANATION

- MEASURED WATER LEVEL, CONTINUOUS

$\times$ MEASURED WATER LEVEL, DISCRETE

SIMULATED WATER LEVEL FOR A STORAGE COEFFICIENT OF:

$$
\begin{array}{r}
\triangle \quad 1 \times 10^{-3} \\
+\quad 5 \times 10^{-4} \\
\circ \quad 1 \times 10^{-4}
\end{array}
$$

Figure 30. Observed and simulated water levels in Upper Floridan aquifer monitoring wells, January 1 to May $25,1990$. 

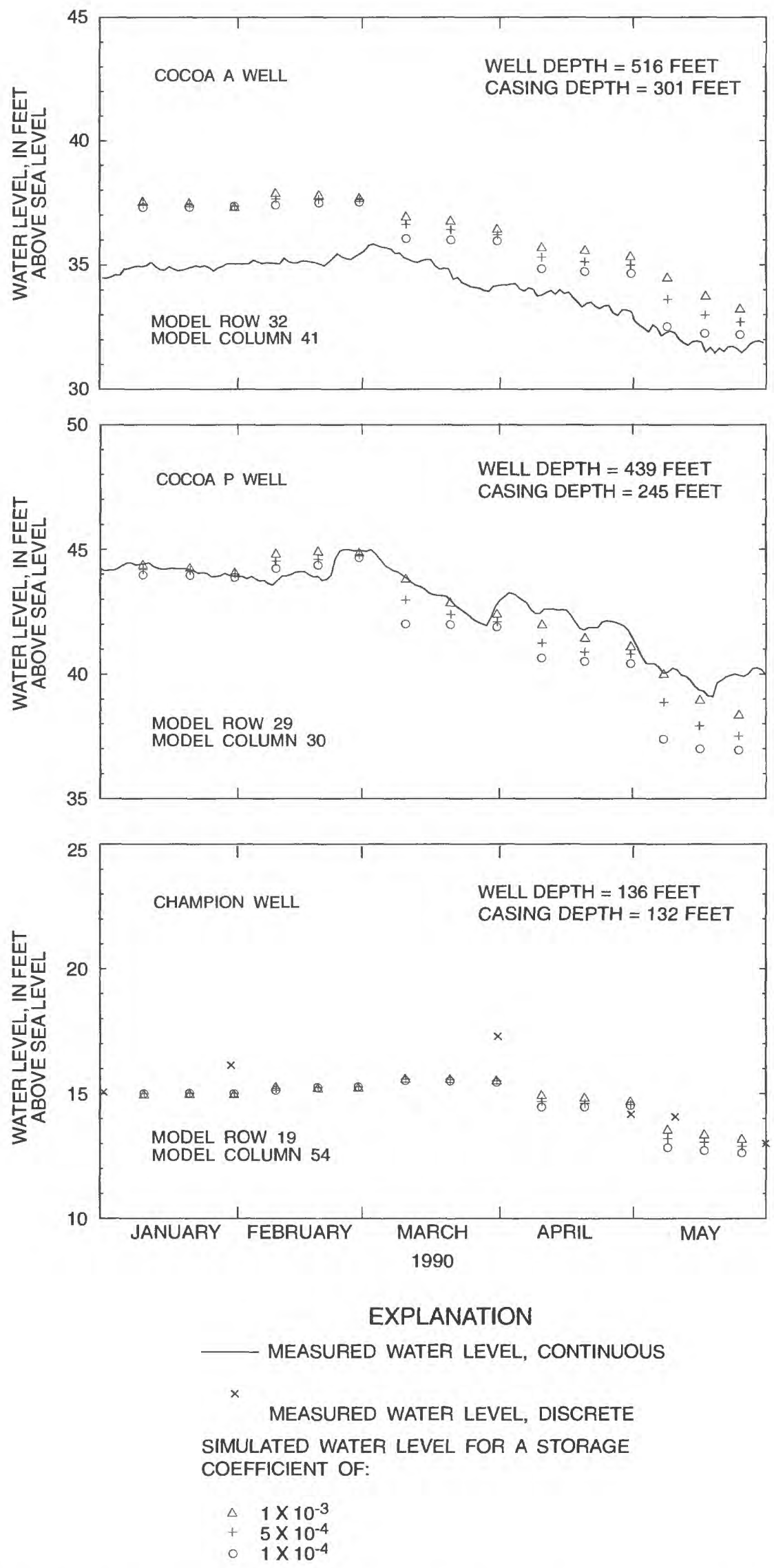

Figure 31. Observed and simulated water levels in Upper Floridan aquifer monitoring wells, January 1 to May 25, 1990. 

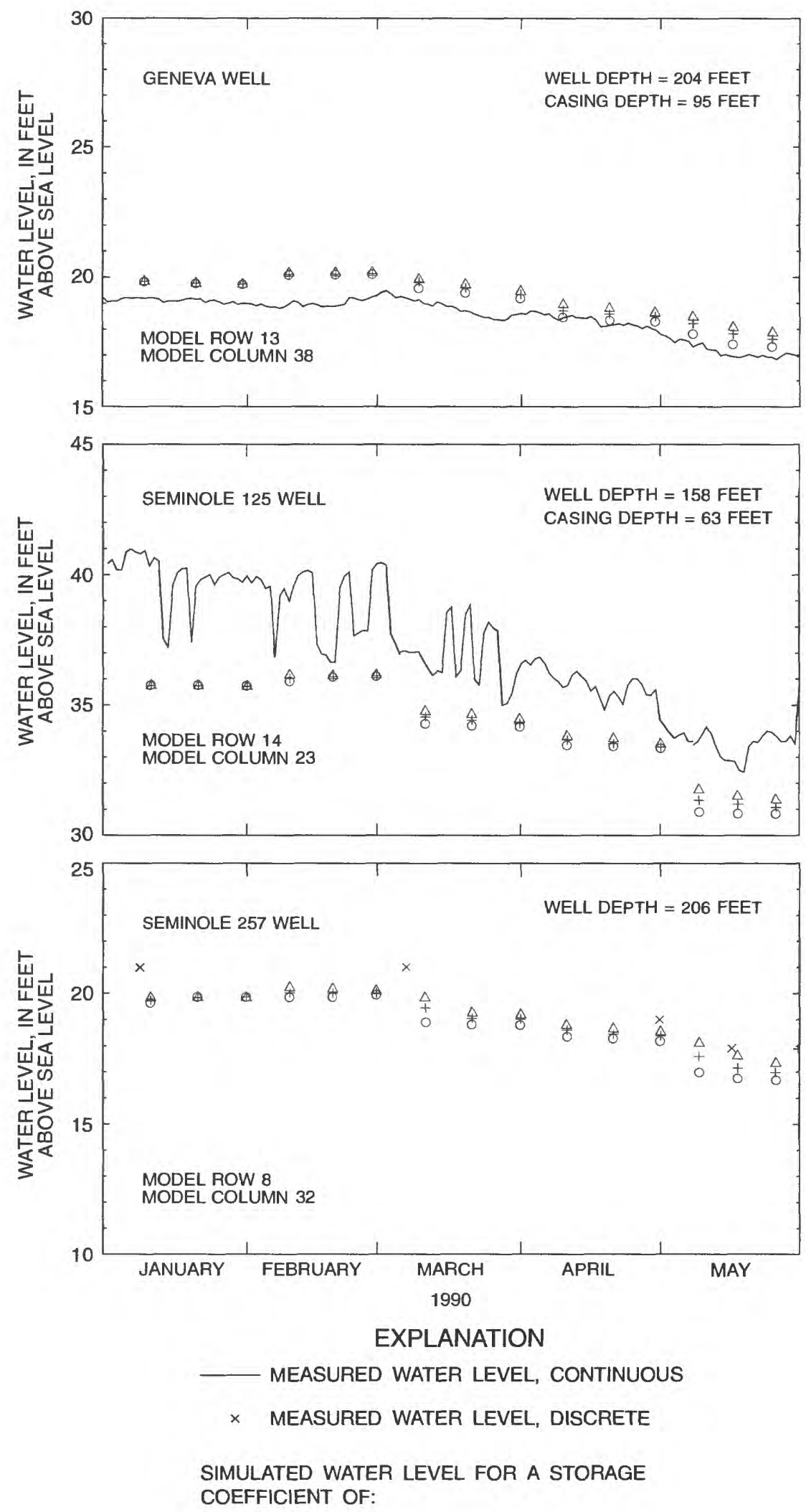

$$
\begin{array}{r}
\triangle \quad 1 \times 10^{-3} \\
+\quad 5 \times 10^{-4} \\
+\quad 1 \times 10^{-4}
\end{array}
$$

Figure 32. Observed and simulated water levels in Upper Floridan aquifer monitoring wells, January 1 to May 25, 1990. 


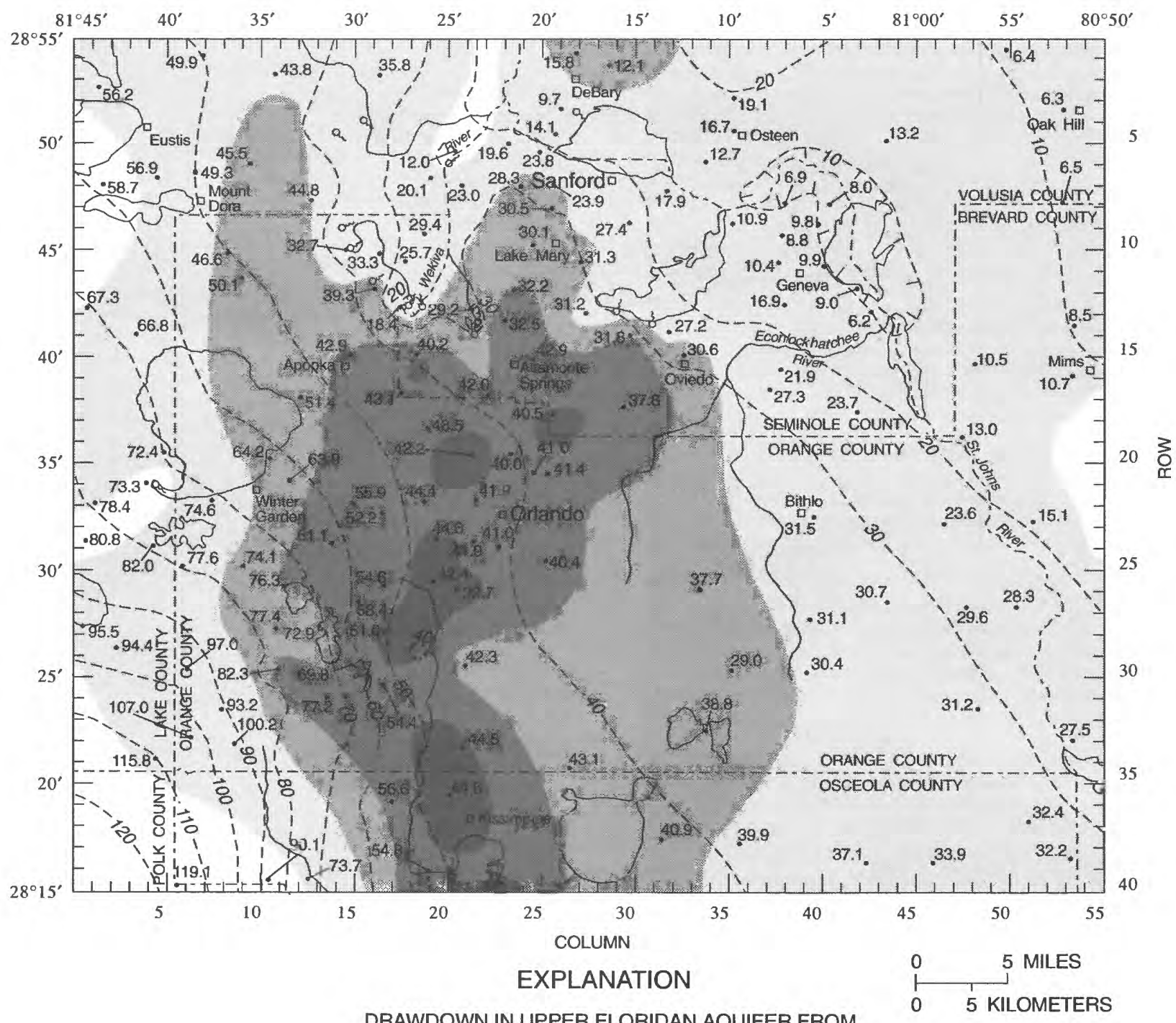

DRAWDOWN IN UPPER FLORIDAN AQUIFER FROM AVERAGE 1988 CONDITIONS TO MAY 25, 1990, IN FEET

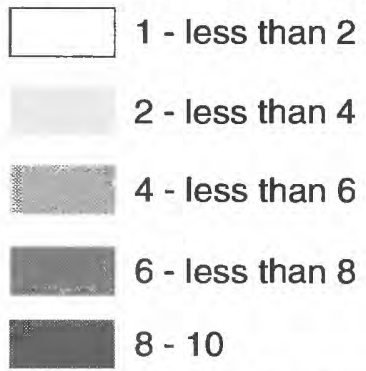

- - 80--- POTENTIOMETRIC SURFACE OF UPPER FLORIDAN AQUIFER--

Derived from computer model simulation of heads.

Shows altitude of potentiometric surface. Hachures indicate depressions. Contour interval 10 feet.

Datum is sea level

39.9.

WELL USED TO MEASURE MAY 1990 UPPER FLORIDAN AQUIFER HEAD --

Number is head, in feet above mean sea level (from Murray, 1990).

Well located by column and row and described in Appendix A

Figure 33. Simulated Upper Floridan aquifer potentiometric surface (May 25, 1990), water levels measured at Upper Floridan aquifer monitoring wells, and observed drawdowns relative to average 1988 conditions. 


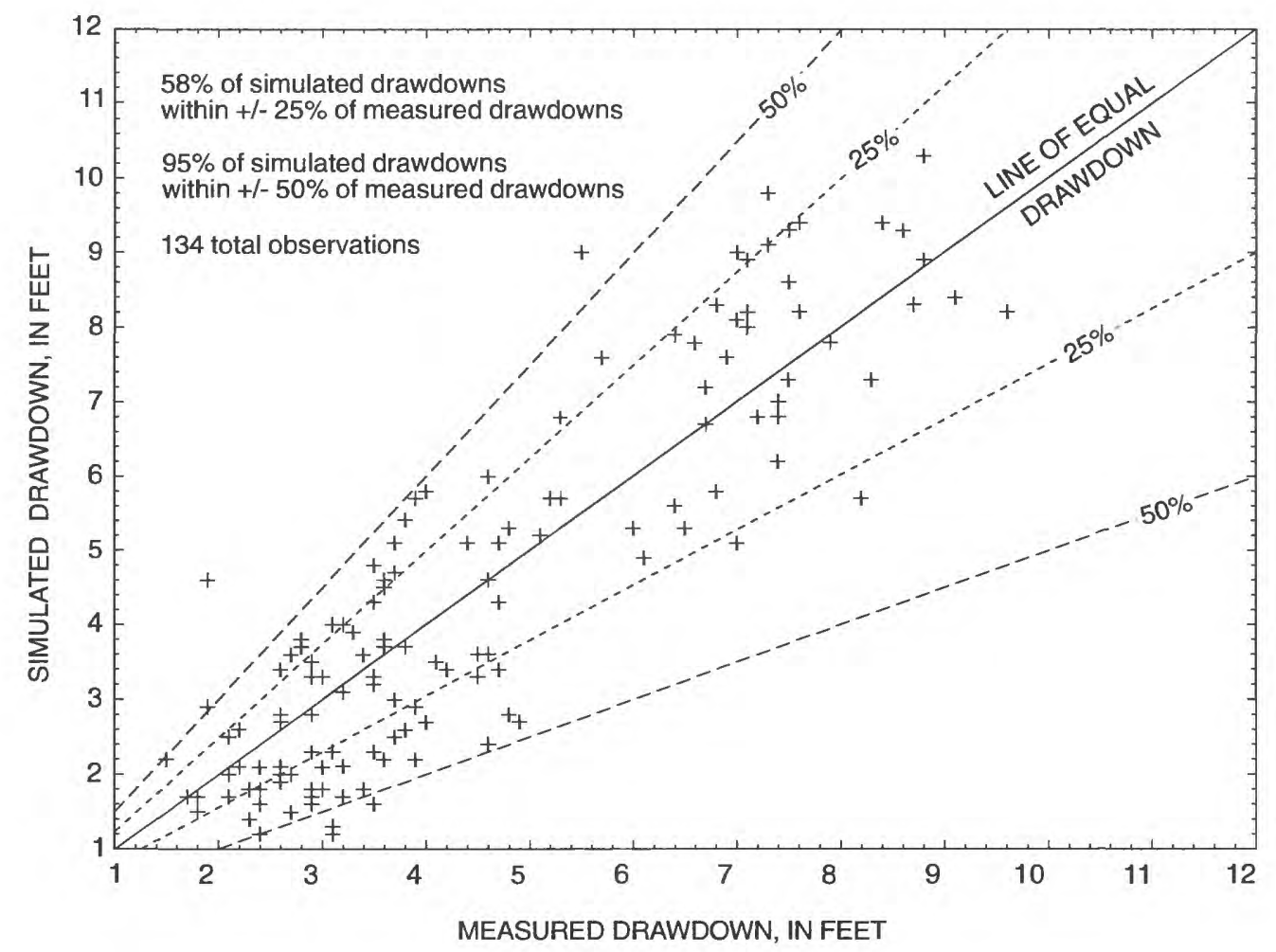

Figure 34. Measured and simulated drawdowns in Upper Floridan aquifer monitoring wells, average 1988 conditions to May 25, 1990.

these areas may be attributed to any or all of several model deficiencies:

(1) Rural-domestic pumpage was not included in the model simulations. Under typical rainfall conditions, the stress imposed by rural-domestic pumpage over the study area is relatively small because the vast majority of the population is served by municipal well fields. In the more rural areas of northwest Orange and east Lake Counties, however, where self-supplied domestic users are concentrated, increased pumpage for lawn irrigation during drought periods could have significantly affected heads in the Upper Floridan aquifer.

(2) Declines of heads in the surficial aquifer system may have been underestimated. Many of these estimates were based on lake-level declines, which may be smaller than actual water-table declines beneath the sandy ridges; thus, heads assigned to the source/sink array may have been too high, resulting in excessive simulated leakage to the Upper Floridan aquifer.

(3) The actual amount of water pumped from the Upper Floridan aquifer to irrigate nurseries in east Lake and northwest Orange Counties may have been underestimated for May 1990. During periods of drought, farmers occasionally exceed permitted withdrawal rates and differences between estimated and actual pumping rates may have been large enough to affect the heads in these areas.

Discharge simulated from Upper Floridan aquifer springs in May 1990 totaled $250 \mathrm{ft}^{3} / \mathrm{s}$, about $56 \mathrm{ft}^{3} / \mathrm{s}$ less than spring flow simulated in 1988 (table 8). This reduction in discharge is greater than the reduction of $50 \mathrm{ft}^{3} / \mathrm{s}$ simulated between predevelopment and average 1988 conditions and illustrates the sensitivity of spring flow to periods of deficit rainfall. Discharge simulated at Wekiva, Rock, Sanlando, Palm, Starbuck, Seminole, Messant, and Miami Springs in May 1990 totaled $184 \mathrm{ft}^{3} / \mathrm{s}$ compared to the measured total of $176 \mathrm{ft}^{3} / \mathrm{s}$ (table 8 ). Simulated spring flow is greater than measured spring flow because drawdowns simulated by the model in northwest Orange County, upgradient from Wekiva and Rock Springs, were less than measured values. Possible explanations for insufficient drawdowns in this area were discussed previously. 
Calibrated Aquifer and Confining-Unit Hydraulic Characteristics

The calibrated leakance array that represents the intermediate confining unit is shown in figure 35. Cal- ibrated values range from $1 \times 10^{-5} / \mathrm{d}$ to $4 \times 10^{-3} / \mathrm{d}$. Values are highest where the confining unit is thinnest or is breached by numerous sinkholes. These areas include northeast Polk and east Lake Counties; west Seminole

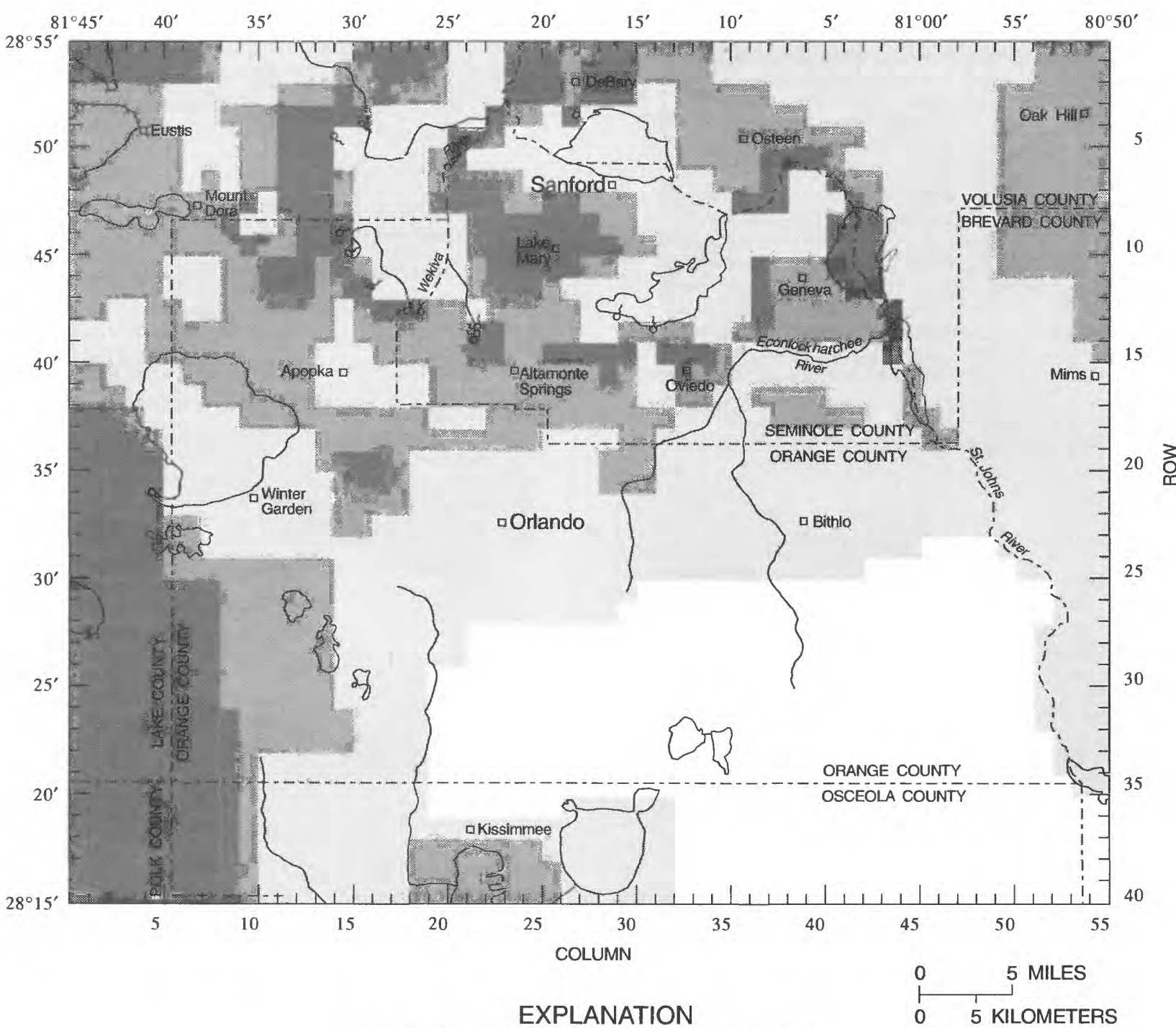

LEAKANCE OF INTERMEDIATE CONFINING UNIT, IN FEET PER DAY PER FOOT

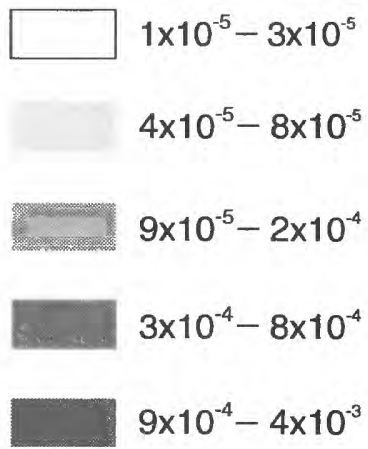

Figure 35. Calibrated leakance of the intermediate confining unit. 
County around the city of Lake Mary and northwest to the Wekiva River; east Seminole County along the St. Johns River; northwest Orange County upgradient from Upper Floridan aquifer springs; and southwest Volusia County north of Lake Monroe. Leakance values are lowest in southeast Orange and northeast Osceola Counties where the confining unit is thickest. The higher leakance values simulated beneath the St. Johns River at the Orange-Osceola County boundary reflect the abrupt decrease in confining unit thickness observed east of the river in Brevard County (fig. 5). Subsurface faulting may exist at or near the river in this area. Model-calibrated leakance values were consistently lower than those derived from aquifer tests, indicating that field-derived values probably include the effects of leakage from below the pumped aquifer; that is, from the Lower Floridan aquifer through the middle semiconfining unit. Generally, model-calibrated leakance values are greatest in areas where aquifer tests have yielded relatively high values and are lowest where aquifer tests have yielded relatively low values.

Leakance values shown at the river cells were calculated by dividing the calibrated CRIV values by the area of the cells. This conversion assumes that the river stage specified in the River package is representative of the average water-table altitude across the cell. This assumption seems reasonable since the topography within the river cells is flat and swampy and observed differences between river stage and the nearby water table are small.

Upper Floridan aquifer transmissivity values derived by model calibration range from 10,000 to more than $400,000 \mathrm{ft}^{2} / \mathrm{d}$ (fig. 36). Calibrated transmissivities for a given area usually exceed transmissivities determined by aquifer tests. However, areas where calibrated transmissivities are high generally correspond to areas where aquifer tests have yielded relatively high values. Similarly, areas of low simulated transmissivities generally correspond to areas where transmissivities based on aquifer tests also are low. The highest calibrated transmissivities (greater than $400,000 \mathrm{ft}^{2} / \mathrm{d}$ ) occur locally at several of the larger Upper Floridan aquifer springs where cavernous conditions are known to exist. Broader areas of high calibrated transmissivity $\left(200,000\right.$ to $\left.400,000 \mathrm{ft}^{2} / \mathrm{d}\right)$ occur in northwest, central, and east Orange County, and in east-central Lake County. The highly transmissive areas in northwest Orange and east-central Lake
Counties are close to and upgradient from Upper Floridan aquifer springs, where the flow fields of the springs capture nearly all of the recharging water. The highly transmissive area in east Orange County covers the east part of the Cocoa well field and is consistent with aquifer-test results. Moderate calibrated transmissivity values $\left(100,000\right.$ to $\left.200,000 \mathrm{ft}^{2} / \mathrm{d}\right)$ occur in east Lake, southwest Seminole, northeast Osceola, and parts of Orange Counties. Tranmissivity determined by aquifer-test analyses in the west part of the Cocoa well field is lower than calibrated values in the east half, consistent with aquifer and specific-capacity test differences measured at production wells in these two areas (Tibbals and Frazee, 1976).

The lowest calibrated transmissivities $(10,000$ to $40,000 \mathrm{ft}^{2} / \mathrm{d}$ ) occur in northeast Polk County and in areas that discharge water from the Upper Floridan aquifer. These discharge areas include the St. Johns River system and adjoining lakes in north and east Seminole County, where measured specific capacities and well yields are low (Tibbals, 1977); the area downgradient from Upper Floridan aquifer springs near the Wekiva River where ground-water velocities are relatively slow; and the area around Reedy Creek where closely spaced potentiometric contours indicate low transmissivity in the Upper Floridan aquifer (fig. 25). In northeast Polk County, transmissivity is reduced by the clayey limestone beds present in the top $100 \mathrm{ft}$ of the Upper Floridan aquifer (Grubb, 1978).

A leakance value of $5 \times 10^{-5} / \mathrm{d}$, obtained from the calibrated RASA model (Tibbals, 1990), was assigned to the middle semiconfining unit array and was adjusted in only a few areas during model calibration (fig. 37). Leakance was increased in central Orange County to $1 \times 10^{-3} / \mathrm{d}$ to more closely simulate the 1 - to 3-ft head differences observed between the Upper and Lower Floridan aquifers in the Orlando area.

Calibrated transmissivity of the Lower Floridan aquifer is greatest $\left(600,000 \mathrm{ft}^{2} / \mathrm{d}\right)$ in central Orange County where aquifer-test results range from 576,000 to $668,000 \mathrm{ft}^{2} / \mathrm{d}$ (fig. 38). Calibrated transmissivities are lowest $\left(5,000\right.$ to $\left.10,000 \mathrm{ft}^{2} / \mathrm{d}\right)$ in north and east Seminole, north Brevard, and southwest Volusia Counties. The freshwater-saltwater interface beneath these areas probably is close to the top of the Lower Floridan aquifer, limiting the movement of freshwater to only a thin part of the aquifer. Ground-water flow velocities within the Lower Floridan aquifer are relatively slow, if not stagnant, in these areas. The singular 


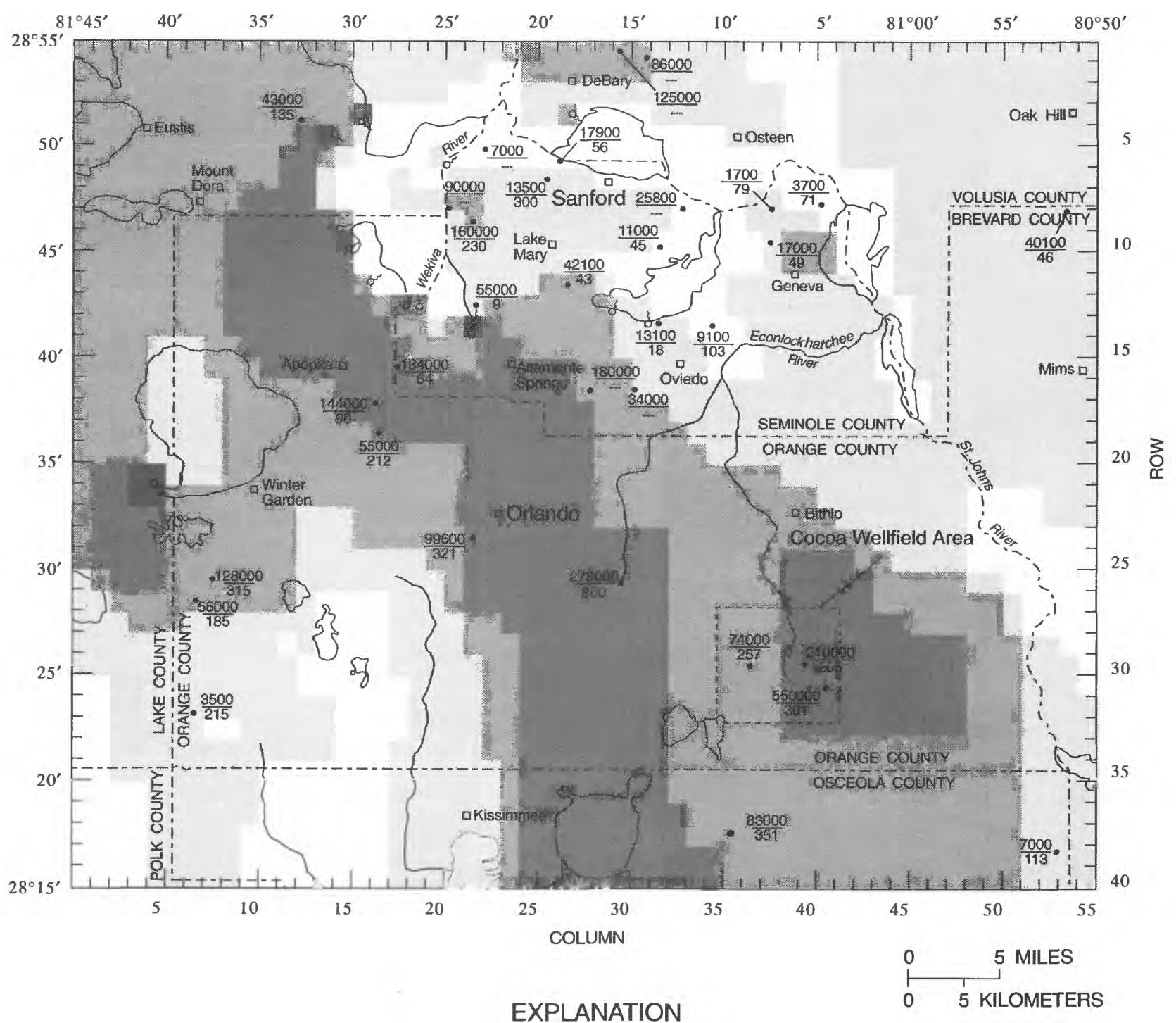

TRANSMISSIVITY, IN FEET SQUARED PER DAY

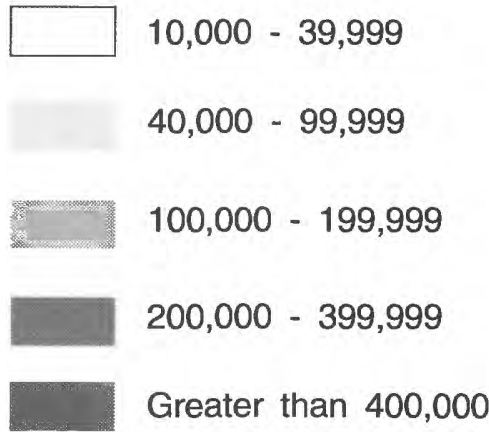

99600 - TRANSMISSIVITY DETERMINED FROM MULTI-WELL

$\frac{99600}{321}$ AQUIFER TEST -- Top number is transmissivity, in feet squared per day. Bottom number is thickness of aquifer penetrated by pumped well, in feet; ---, data not available

Figure 36. Calibrated transmissivity of the Upper Floridan aquifer and results of selected aquifer tests. 


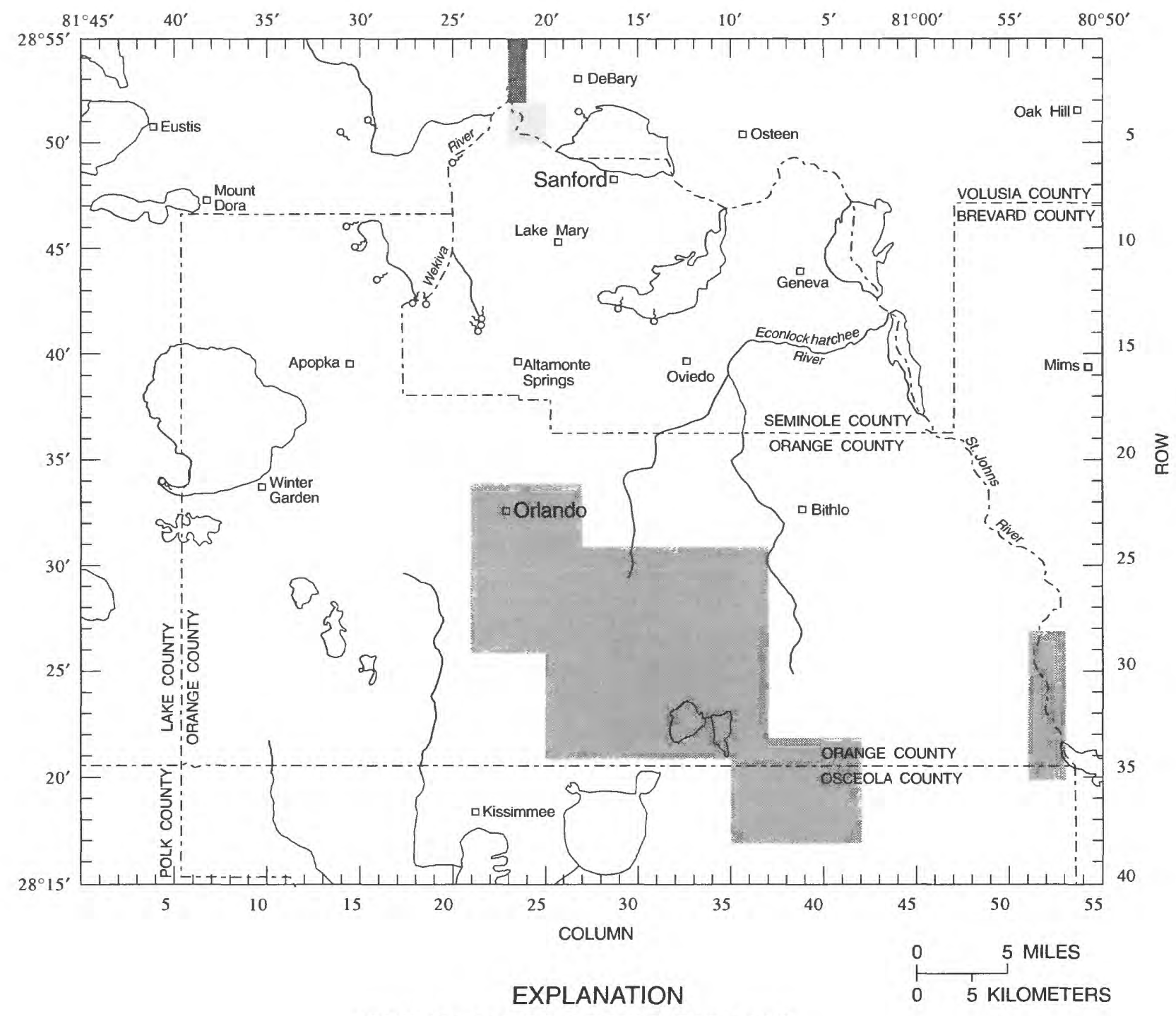

LEAKANCE OF MIDDLE SEMICONFINING UNIT, IN FEET PER DAY PER FOOT

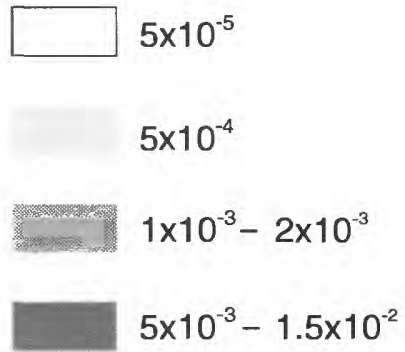

Figure 37. Calibrated leakance of the middle semiconfining unit of the Floridan aquifer system.

distribution of intermediate transmissivities $(60,000$ and $\left.130,000 \mathrm{ft}^{2} / \mathrm{d}\right)$ shown in figure 38 was taken from Tibbals (1981) and was not changed during model calibration.

\section{Recharge and Discharge Rates}

Simulated recharge from the surficial aquifer system to the Upper Floridan aquifer occurs across 


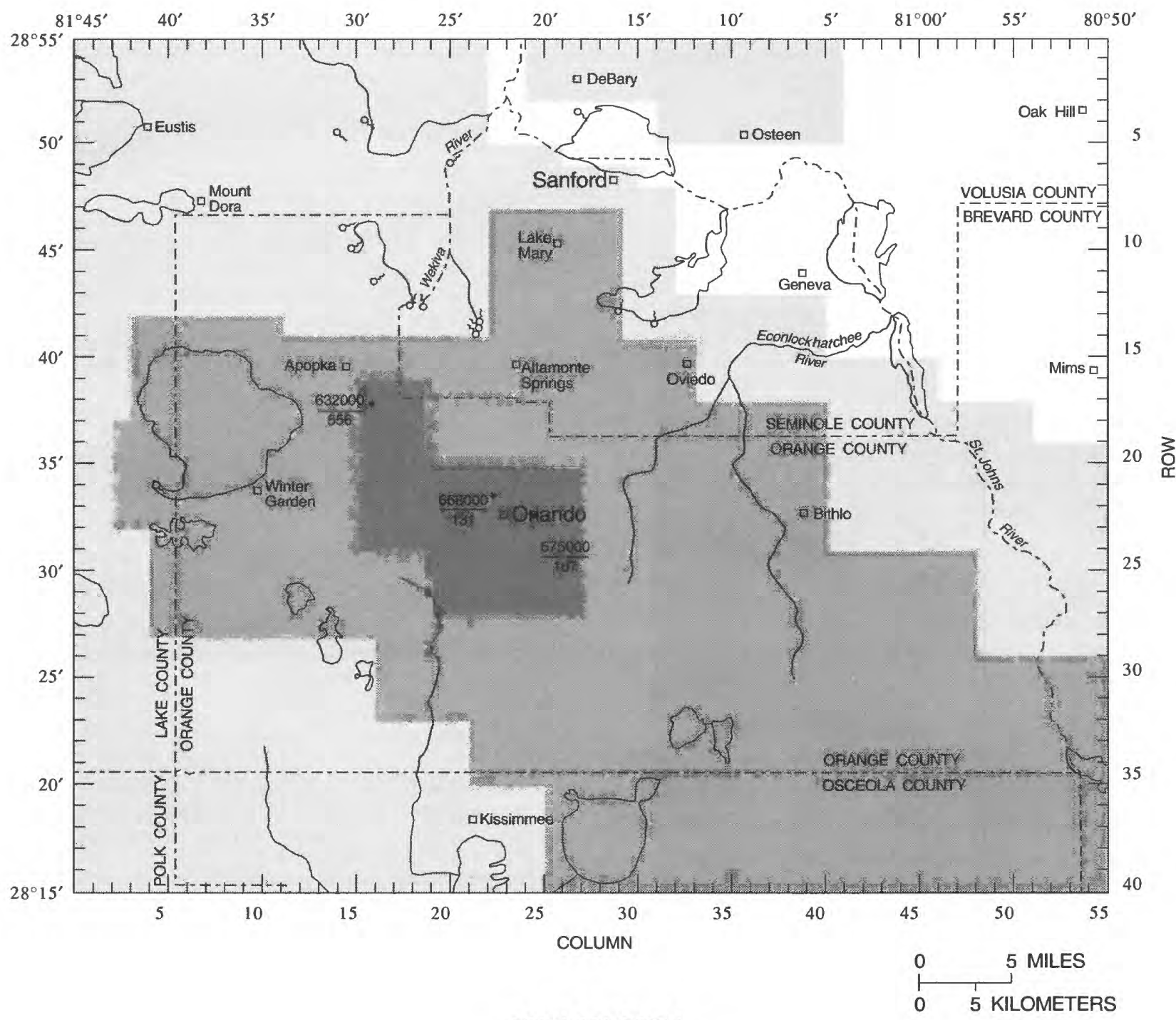

EXPLANATION

TRANSMISSIVITY, IN FEET SQUARED

PER DAY

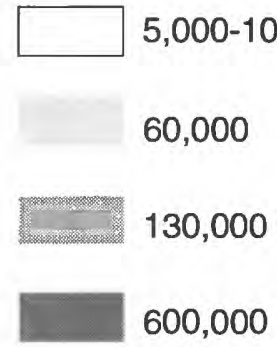

TRANSMISSIVITY DETERMINED FROM MULTIWELI

632,000 - AQUIFER TEST - Top number is transmissivity, in feet squared

per day. Bottom number is thickness of aquifer penetrated

by pumped well, in feet

Figure 38. Calibrated transmissivity of the Lower Floridan aquifer and results of selected aquifer tests. 
75 percent of the study area. Simulated 1988 recharge rates range from less than 1 to $21 \mathrm{in} / \mathrm{yr}$, with an average of $4.2 \mathrm{in} / \mathrm{yr}$ over the study area (fig. 39). Recharge rates were calculated for each model cell by multiplying the calibrated leakance by the difference in head between the surficial and Upper Floridan aquifers. The distribution of recharge and discharge areas shown in figure 39 generally are consistent with those mapped by previous investigators (fig. 7). Highest recharge rates (10-21 in/yr) cover about 16 percent of the study area and occur in east Lake, west Orange, west Seminole, and southwest Volusia Counties. Areas of high recharge (fig. 39) generally correspond with areas of relatively high intermediate confining unit leakance (fig. 35) and are characterized by either karstic topography or a relatively thin intermediate confining unit. Areas with low simulated recharge rates $(0-3 \mathrm{in} / \mathrm{yr})$ occur across central Orange, north Osceola, and south Volusia Counties where the water table is closer to land surface and surface runoff and evapotranspiration rates are relatively high.

Lateral recharge to the Upper Floridan aquifer occurs primarily across the west model boundary in Lake County (fig. 39). The highest rates of simulated inflow occur across the west-central part of the boundary, to the west of Lake Apopka and Apopka Spring. Relatively little water moves laterally across the southwest boundary in Polk County, where calibrated transmissivities are relatively low. Simulated outflow rates are highest along the northwest boundary (north of the city of Eustis) and along the north-central boundary (toward Blue Springs, about 2 mi north of the boundary). Water is also discharged across the east model boundary toward the Atlantic Ocean.

Discharge from the Upper Floridan aquifer to the surficial aquifer system and to the St. Johns River system by diffuse upward leakage occurs across 25 percent of the study area. Simulated rates range from 1 to $4 \mathrm{in} / \mathrm{yr}$ and occur beneath the St. Johns River and adjacent topographically low areas, downgradient from Upper Floridan aquifer springs and beneath the Wekiva River, beneath Reedy Creek and the western half of Lake Apopka, and in low-lying areas of south Volusia County. Substantially higher discharge rates were simulated beneath the St. Johns River just upstream from and in the southwest part of Lake Harney $\left(24 \mathrm{ft}^{3} / \mathrm{s}\right.$ or $\left.282 \mathrm{in} / \mathrm{yr}\right)$, between Lake Harney and Lake Jesup $\left(11 \mathrm{ft}^{3} / \mathrm{s}\right.$ or $\left.129 \mathrm{in} / \mathrm{yr}\right)$, and at the confluence of the St. Johns and Wekiva Rivers $\left(9 \mathrm{ft}^{3} / \mathrm{s}\right.$ or
$106 \mathrm{in} / \mathrm{yr}$, fig. 39). Undocumented Upper Floridan aquifer springs may exist in these areas.

\section{Sensitivity Analyses}

A sensitivity analysis was performed to determine the degree to which the calibrated model results are affected by changes in model parameters and aquifer stresses. These parameters include Upper and Lower Floridan aquifer transmissivity, intermediate confining unit leakance, middle semiconfining unit leakance, drain and river conductances, specified GHB heads, and fixed surficial aquifer heads. Tested stresses include drainage-well recharge, agricultural and golf course pumpage, and abandoned flowing-well discharge. The parameters and stresses were varied uniformly, one at a time, over a range judged equal to or greater than the estimated error related to the calibrated parameter or assigned stress. Subsequent changes in the average absolute error computed for the 1988 calibration $(1.8 \mathrm{ft}$ ) and Upper Floridan aquifer spring flow $\left(306 \mathrm{ft}^{3} / \mathrm{s}\right)$ were calculated and plotted (fig. 40). Those parameters or stresses that produce the greatest change in calibrated heads or spring flow are better estimated by the model than are parameters or stresses that produce smaller changes. Sensitivity-test results for the aquifer stresses are not plotted in figure 40, but are discussed below.

Simulated Upper Floridan aquifer heads were most sensitive to changes in intermediate confining unit leakance, moderately sensitive to changes in Upper Floridan aquifer transmissivity, and relatively insensitive to changes in river and drain conductances, middle semiconfining unit leakance, and Lower Floridan aquifer transmissivity (fig. 40). Simulated spring flow was highly sensitive to changes in both Upper Floridan aquifer transmissivity and intermediate confining unit leakance, moderately sensitive to drain conductance, and insensitive to river conductance, middle semiconfining unit leakance, and Lower Floridan aquifer transmissivity.

Simulated Upper Floridan aquifer heads and spring flow were moderately sensitive to potential errors in specified surficial aquifer heads (fig. 40). Changes to specified heads of plus or minus $5 \mathrm{ft}$ increased the average absolute error from 1.8 to $4.0 \mathrm{ft}$ and reduced (or increased) spring flow by about $50 \mathrm{ft}^{3} / \mathrm{s}$. Upper Floridan aquifer heads were most sensitive to changes in surficial aquifer heads where intermediate confining unit leakances are high and head differences between these aquifers are small. Upper 


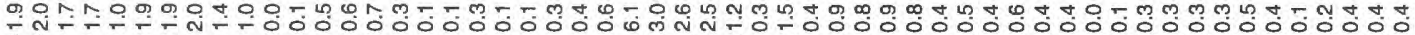

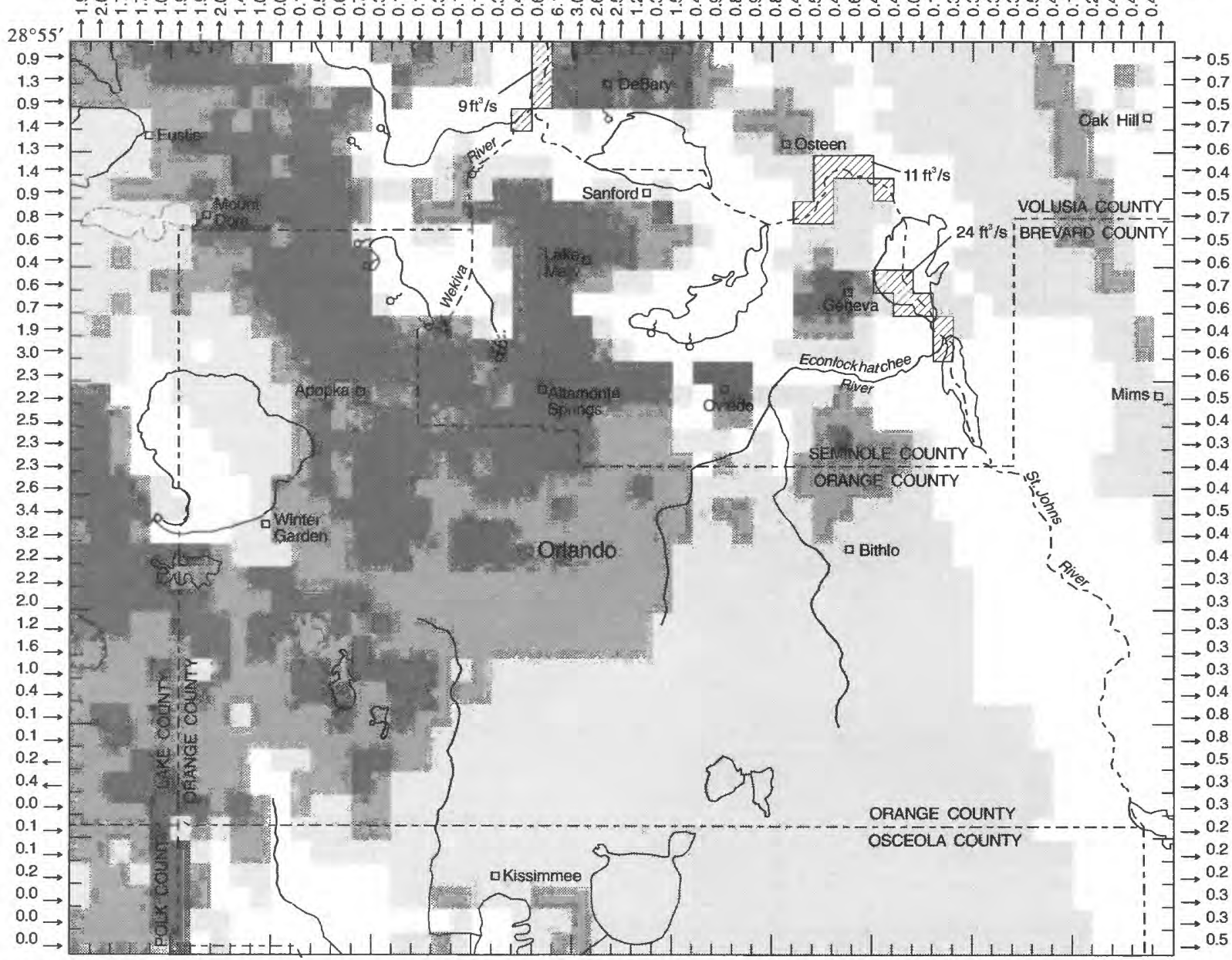

$28^{\circ} 15^{\prime} \uparrow \uparrow \uparrow \uparrow \uparrow \uparrow \uparrow \uparrow \uparrow \uparrow \uparrow \uparrow \uparrow \uparrow \uparrow \uparrow \uparrow \uparrow \uparrow \uparrow \uparrow \uparrow \uparrow \uparrow \uparrow \uparrow \uparrow \uparrow \mid \uparrow \uparrow \uparrow \uparrow \uparrow \uparrow \uparrow \uparrow \uparrow \uparrow \uparrow \uparrow \uparrow \uparrow \uparrow \uparrow \uparrow \uparrow \uparrow \uparrow \uparrow \uparrow \uparrow \uparrow \uparrow \uparrow$

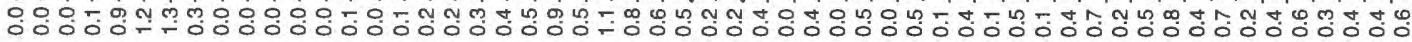

\section{EXPLANATION}

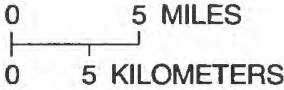

RATE OF RECHARGE TO THE UPPER FLORIDAN AQUIFER, INCHES PER YEAR

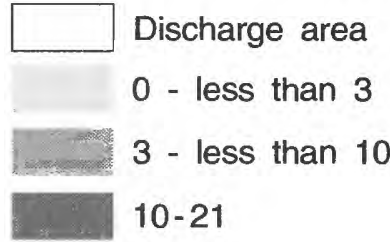

$24 \mathrm{ft}^{3} / \mathrm{s}$ Number is total simulated discharge within shaded area, in cubic feet per second

Area of significant discharge simulated by the RIVER package.

$\leftarrow 0.5$ Direction and rate of lateral flow, in cubic feet per second

Figure 39. Simulated rates of recharge to and discharge from the Upper Floridan aquifer through the intermediate confining unit and lateral flow to and from the Upper Floridan aquifer across model boundaries, average 1988 steady-state conditions. 

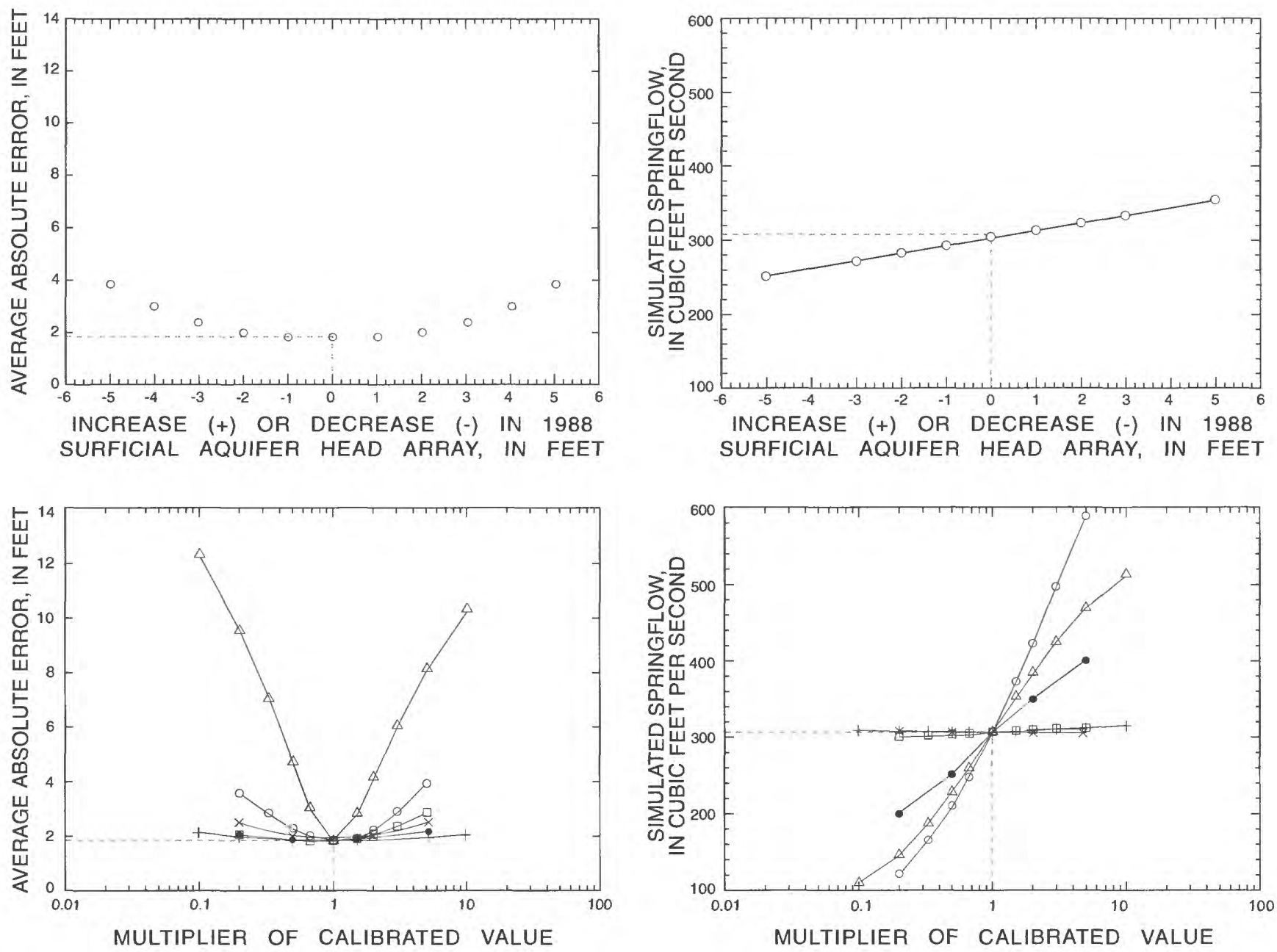

\section{EXPLANATION}

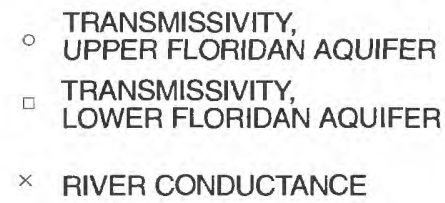

LEAKANCE OF THE
$\triangle$ INTERMEDIATE INTERMEDIATE
CONFINING UNIT

+ LEAKANCE OF THE MIDDLE SEMICONFINING UNIT

- DRAIN CONDUCTANCE

Figure 40. Sensitivity of Upper Floridan aquifer heads and spring flow to variations in calibrated model parameters and in specified surficial aquifer heads.

Floridan aquifer heads were less affected by changes in surficial aquifer heads where the leakances are low and differences in head between the aquifers are large. These results indicate that additional monitoring of surficial aquifer water levels is needed to better predict the response of Upper Floridan aquifer heads to changes in stressed conditions. Additional monitoring is particularly necessary in areas like west Seminole, southwest Volusia, and parts of northwest Orange County where confining unit leakances are high and pumping rates are projected to increase.
Simulated Upper Floridan aquifer heads and spring flow were relatively insensitive to changes in drainage-well recharge. Doubling the applied 1988 recharge rate (to $60 \mathrm{Mgal} / \mathrm{d}$ ) increased the average absolute error from 1.8 to $2.1 \mathrm{ft}$ and spring flow from 306 to only $314 \mathrm{ft}^{3} / \mathrm{s}$; reducing the discharge by one-half (to $15 \mathrm{Mgal} / \mathrm{d}$ ) produced similarly small changes. In a separate simulation, drainage-well recharge was set equal to zero to simulate the effects of plugging all the drainage wells in the study area. Declines in Upper Floridan aquifer heads ranged from 
1 to $3 \mathrm{ft}$ in parts of central and north-central Orange County, where drainage wells are most concentrated. The greatest declines in head were simulated at the Lake Underhill and Lake Killarney drainage wells. Cumulative spring flow was reduced by 3 percent (from 306 to $298 \mathrm{ft}^{3} / \mathrm{s}$ ) and discharge from the Sanlando Springs group was reduced by 8 percent (from 40 to $37 \mathrm{ft}^{3} / \mathrm{s}$ ).

Simulated Upper Floridan aquifer heads were relatively insensitive to changes in agricultural and golf course pumpage and to flowing-well discharge rates. Doubling of agricultural and golf course pumping rates increased the average absolute error from 1.8 to $1.9 \mathrm{ft}$ and decreased simulated spring flow from 306 to $298 \mathrm{ft}^{3} / \mathrm{s}$. Reducing these withdrawals by one-half increased the average absolute error to $2.0 \mathrm{ft}$ and increased simulated spring flow to $314 \mathrm{ft}^{3} / \mathrm{s}$. Doubling of flowing-well discharge rates increased the average absolute error to $2.0 \mathrm{ft}$ and reduced simulated spring flow to $304 \mathrm{ft}^{3} / \mathrm{s}$. Reducing discharge rates by one-half had virtually no effect on the average absolute error and increased simulated spring flow to $307 \mathrm{ft}^{3} / \mathrm{s}$.

The sensitivity of simulated 1988 heads and spring flow to changes in specified GHB heads was tested by simulating 1988 conditions in which specified 1988 GHB head array was replaced by the predevelopment GHB head array. Predevelopment GHB heads were about $10 \mathrm{ft}$ higher than $1988 \mathrm{GHB}$ heads at the south-central boundary and less than $5 \mathrm{ft}$ higher than 1988 GHB heads at the east, north, and west boundaries. Spring flow was relatively insensitive to these changes, increasing from 306 to $313 \mathrm{ft}^{3} / \mathrm{s}$. Apparently, the springs are located far enough away from model boundaries to be relatively unaffected by potential errors in specified GHB heads. The average absolute error computed from this simulation increased from 1.8 to $2.7 \mathrm{ft}$. Water levels simulated in north-central Osceola County were up to $5 \mathrm{ft}$ greater than those simulated by the model using 1988 GHB heads. Water levels in Seminole, east Lake, northeast Polk, west Orange, and in southwest Volusia Counties generally were within $1 \mathrm{ft}$ of those simulated by the model using 1988 GHB heads. Lateral inflow to the Upper Floridan aquifer increased by $45 \mathrm{ft}^{3} / \mathrm{s}$ when predevelopment GHB heads were used in place of 1988 GHB heads to simulate 1988 conditions. This increase is relatively small when compared with the 1988 volumetric budget of $995 \mathrm{ft}^{3} / \mathrm{s}$ (fig. 28). Most of the water discharged by Upper Floridan aquifer wells is not derived from lateral inflow across model boundaries, but from vertical recharge of water from the surficial aquifer system within model boundaries.

\section{Effects of Projected 2010 Ground-Water Withdrawals}

The ground-water flow model described in this report reasonably simulates measured historic Upper Floridan aquifer heads and spring flow and the effects of modern-day (1988) ground-water development on the system. The calibrated model can now be used to evaluate the potential effects of projected year 2010 ground-water withdrawals on steady-state Upper Floridan aquifer water levels, spring flow, and areas that contribute recharge to selected springs and well fields.

\section{Projected Water Use}

Pumpage from the Floridan aquifer system in 2010 is estimated at $542 \mathrm{Mgal} / \mathrm{d}\left(839 \mathrm{ft}^{3} / \mathrm{s}\right)$, nearly an 80 percent increase from 1988 rates. This increase is attributed soley to additional pumpage from municipal and commercial well fields. Pumping rates for industrial, agricultural, and golf course demands in 2010 were assumed equal to 1988 rates because relatively little growth is anticipated in these demands. Discharge from the aquifer by flowing wells and recharge to the system by drainage wells and by land application of reclaimed water also were assumed constant at 1988 rates.

Pumping rates estimated for municipal and commercial users in 2010 were provided by SJRWMD. Withdrawals from Upper Floridan aquifer well fields were projected to be $366 \mathrm{Mgal} / \mathrm{d}\left(567 \mathrm{ft}^{3} / \mathrm{s}\right)$ compared to $230 \mathrm{Mgal} / \mathrm{d}$ pumped in 1988; pumpage from the Lower Floridan aquifer was projected to be $176 \mathrm{Mgal} / \mathrm{d}\left(272 \mathrm{ft}^{3} / \mathrm{s}\right)$, compared to $75 \mathrm{Mgal} / \mathrm{d}$ in 1988. Several new well fields are expected to be operating by 2010 . The most significant new Upper Floridan aquifer well field is the Orange County eastern regional well field (OCERW), which is projected to withdraw about $20 \mathrm{Mgal} / \mathrm{d}$ in 2010 (fig. 41). The estimated distribution of pumpage from the Lower Floridan aquifer in 2010 is shown in figure 42 . Projected 2010 pumping rates for municipal, commercial, and industrial users are listed in appendix C.

The simulated results discussed in this section are unique to a particular set of pumping locations and rates. If actual 2010 rates or locations differ from those 


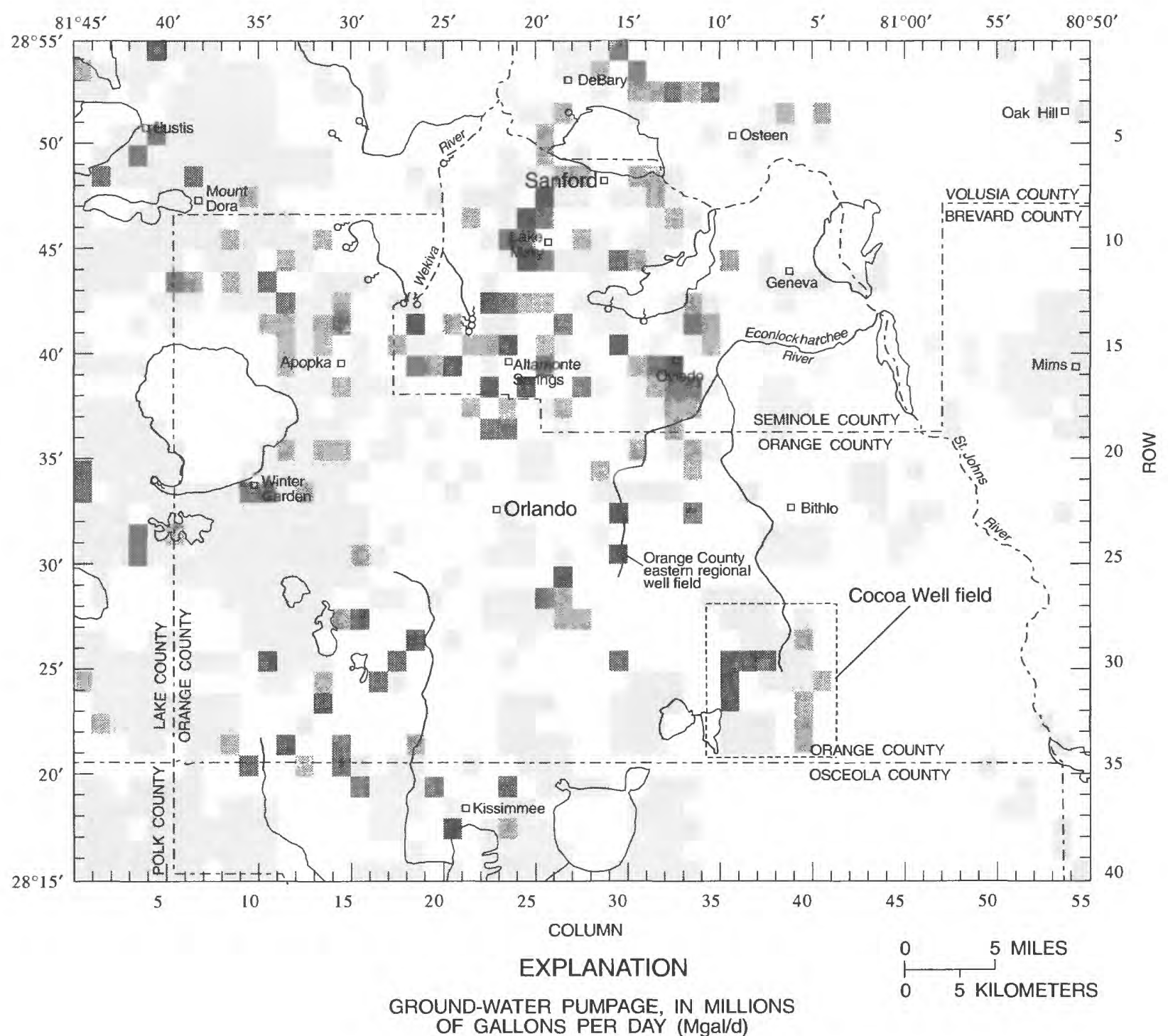

OF GALLONS PER DAY (Mgal/d)

Less than 0.3

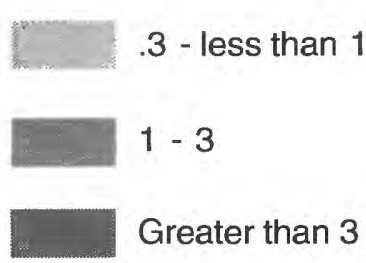

(Total pumpage $=368 \mathrm{Mgal} / \mathrm{d})$

Figure 41. Distribution of projected 2010 Upper Floridan aquifer pumpage and location of new well field.

referenced above, then corresponding simulations would be required to evaluate the respective 2010 conditions.

\section{Projected Boundary Heads}

Specified heads assigned at model boundaries for the predevelopment, 1988, and January to May 


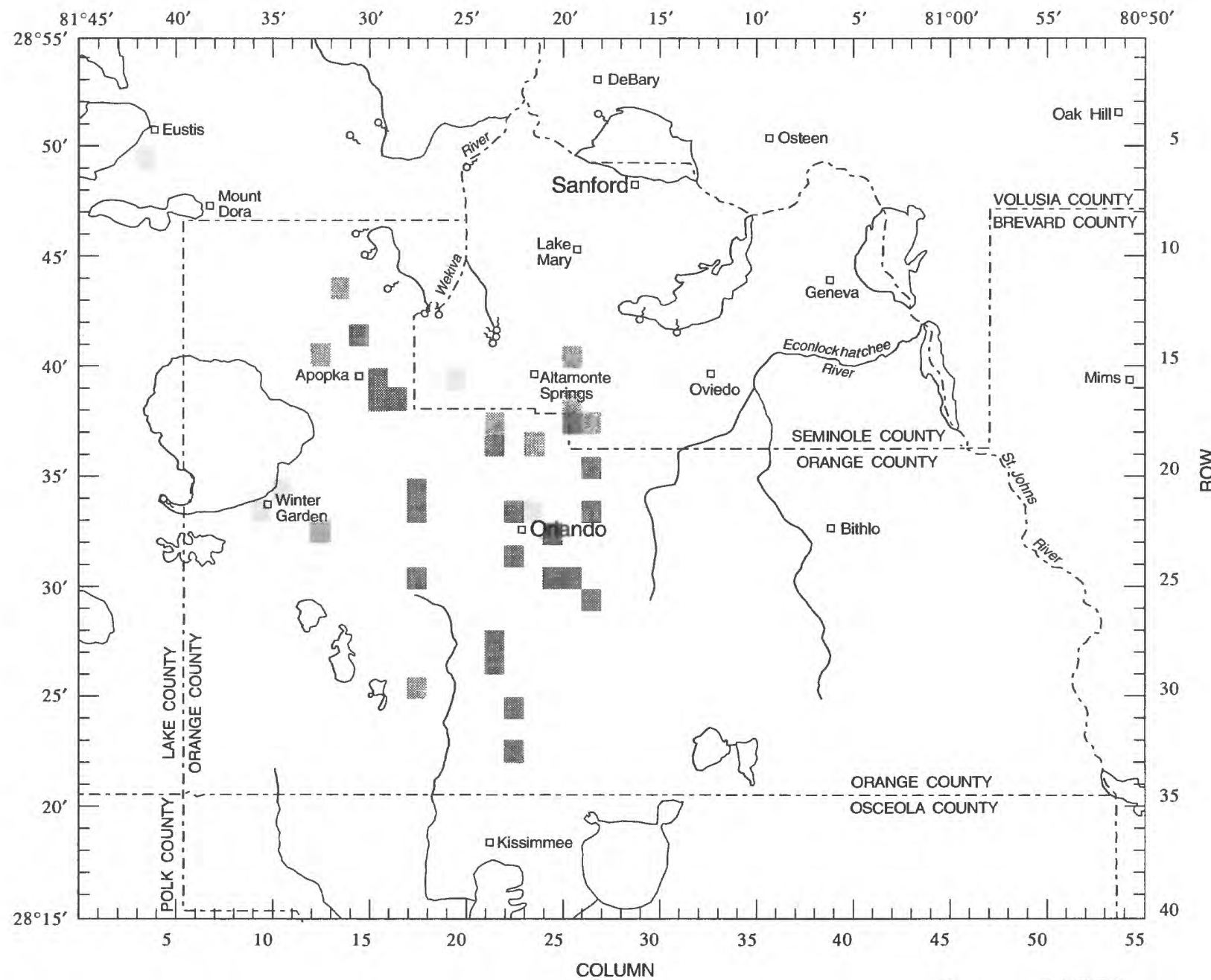

EXPLANATION

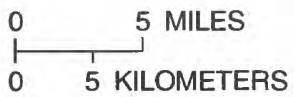

GROUND-WATER PUMPAGE, IN MILLIONS

OF GALLONS PER DAY (Mgal/d)

0 - less than 1

1 - less than 3

$3-9$

$($ Total pumpage $=176 \mathrm{Mgal} / \mathrm{d})$

Figure 42. Distribution of projected 2010 Lower Floridan aquifer pumpage.

1990 simulations were estimated from available hydrologic data. For the 2010 simulations, distributed heads at the source/sink array and other fixed-head values are not known but, for the purposes of this study, are assumed to fall within an estimated range of values represented by average 1988 and May 1990 conditions. Under average rainfall conditions, future 2010 surficial aquifer system heads probably would be lower than those used to represent 1988 conditions because of increased 2010 pumpage. However, aver- 
age 2010 surficial aquifer heads probably would be higher than those observed in May 1990. May 1990 heads were affected by both a 40 percent increase in Floridan aquifer pumpage (as compared to 1988) and an extended period of deficient rainfall. Similarly, actual 2010 fixed spring-pool heads, river heads, and drainage-well recharge rates, under average rainfall conditions, would likely fall somewhere between the values used in respective 1988 and May 1990 arrays. Accordingly, the model was run once with 2010 pumping rates and 1988 fixed-head arrays (representing wet 2010 conditions) and once with 2010 pumping rates and May 1990 fixed-head arrays (representing dry 2010 conditions). Drawdowns and reductions in spring flow projected for wet and dry conditions provide estimates of the range of potential effects of 2010 pumping rates on the Floridan aquifer system under average rainfall conditions.

Unlike the previous simulations, the boundary heads specified in the GHB package are unknowns for projected 2010 conditions and could not be interpolated from water-level measurements. Boundary heads in 1988 were lowered by as much as $10 \mathrm{ft}$ from predevelopment levels by $305 \mathrm{Mgal} / \mathrm{d}$ of pumpage, and increased 2010 pumpage would be expected to further lower these heads. Instead, the regional RASA model (Tibbals, 1990) was used to estimate the change in specified GHB heads due to increased 2010 pumpage. In doing so, the RASA model was run twice to generate two sets of projected GHB head changes, one each for projected wet and dry conditions. In the first simulation, the differences between 1988 and projected 2010 pumping rates were input to the RASA model. Then the change in heads simulated by the RASA model at locations coincident with the GHB heads in the Orlando model were identified. These "drawdowns" were then subtracted from the 1988 GHB array to produce the GHB array used in the Orlando model for simulating 2010 wet conditions. In the second simulation, differences between May 1990 and 2010 pumping rates were input into the RASA model to simulate drawdowns that were subtracted from the May 1990 GHB array. This resultant GHB array was used in the Orlando model for simulating 2010 dry conditions.

\section{Water Levels and Spring Flow}

The steady-state Upper Floridan aquifer potentiometric surfaces simulated for wet and dry conditions in 2010 are shown in figure 43. Compared to the aver- age 1988 surface (fig. 10), the 2010 surfaces are most affected in central and southwest Orange County, where increased Floridan aquifer withdrawals are greatest. Drawdowns in these areas range from 10 to $20 \mathrm{ft}$, with a local maximum of about $30 \mathrm{ft}$ at the OUC Martin well field (model row 29, column 19) (fig. 44). In Seminole County, projected drawdowns for both wet and dry conditions range from greater than $10 \mathrm{ft}$ in the south-central part of the county to less than $2 \mathrm{ft}$ in the northeast part of the county. Drawdowns of less than $2 \mathrm{ft}$ were simulated in parts of northeast Polk, east Lake, south Volusia, and north Brevard Counties. The differences in drawdown between projected 2010 wet and dry conditions were generally less than $1 \mathrm{ft}$ in these less populated areas, whereas differences of up to $3 \mathrm{ft}$ were simulated in parts of central and southwest Orange County. The larger differences simulated near Orlando are due primarily to differences in applied drainage-well recharge rates. For projected 2010 wet conditions, $30 \mathrm{Mgal} / \mathrm{d}$ of recharge were applied, twice the rate applied for projected 2010 dry conditions.

Projected drawdowns in the Upper Floridan aquifer caused by increased Lower Floridan aquifer withdrawals in 2010 ranged from about 4 to greater than $8 \mathrm{ft}$ in central Orange County (fig. 45), where Lower Floridan aquifer pumpage is concentrated (fig. 42). Drawdowns were calculated by subtracting the heads simulated for 2010 wet conditions from the heads simulated in a separate model run in which Lower Floridan aquifer pumping rates were held constant at 1988 levels. The drawdowns contoured in figure 45 are considered gross estimates because model-calibrated values for middle semiconfining unit leakance and Lower Floridan aquifer transmissivity are subject to error. If leakance of the middle semiconfining unit in central Orange County is greater than model-calibrated values, then the maximum drawdown may be greater than that shown in figure 45. If leakances are less than calibrated values, then the maximum drawdown may be less.

Relative to 1988 conditions, simulated spring flow from the Upper Floridan aquifer was reduced by $43 \mathrm{ft}^{3} / \mathrm{s}$ (14 percent) for wet conditions and by $67 \mathrm{ft}^{3} / \mathrm{s}$ (22 percent) for dry conditions (table 9). The largest reduction (32 and 37 percent for wet and dry conditions, respectively) occurred at the Sanlando Springs group, which is located near several large-capacity well fields. Smaller decreases were simulated at Wekiva Springs (13 and 23 percent), Apopka Spring (13 and 22 percent), Rock Springs (12 and 16 percent), 


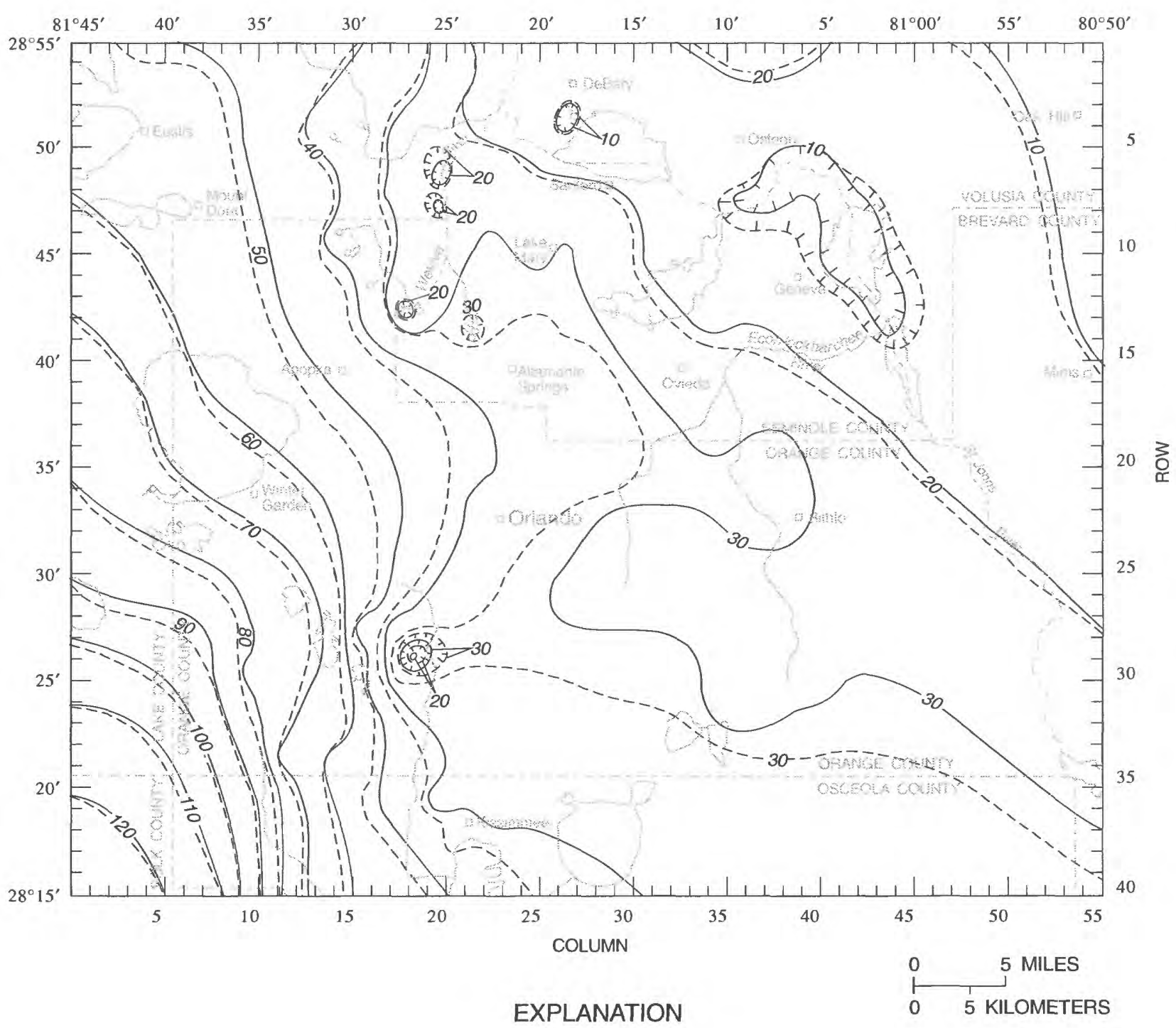

POTENTIOMETRIC SURFACE OF UPPER FLORIDAN AQUIFER

Shows altitude of potentiometric surface. Hachures indicate

depressions. Contour interval 10 feet. Datum is sea level

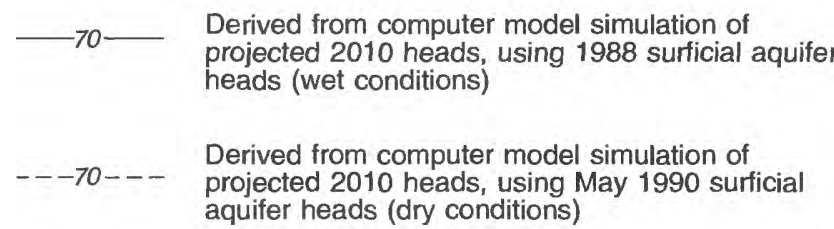

Figure 43. Simulated Upper Floridan aquifer potentiometric surfaces for projected 2010 wet and dry conditions.

Seminole Spring (10 and 24 percent), and Messant Spring ( 6 and 12 percent). For both 2010 wet and dry conditions, increased pumpage from the Lower Floridan aquifer contributed to about $17 \mathrm{ft}^{3} / \mathrm{s}$ (40 and 25 percent, respectively) of the reduced spring flow.
Simulated hydrologic budgets shown in table 10 document the changes induced by 2010 pumpage on the 1988 ground water-flow conditions in the Floridan aquifer system. Increased pumpage from the Floridan aquifer system in $2010\left(366 \mathrm{ft}^{3} / \mathrm{s}\right)$ is derived primarily 

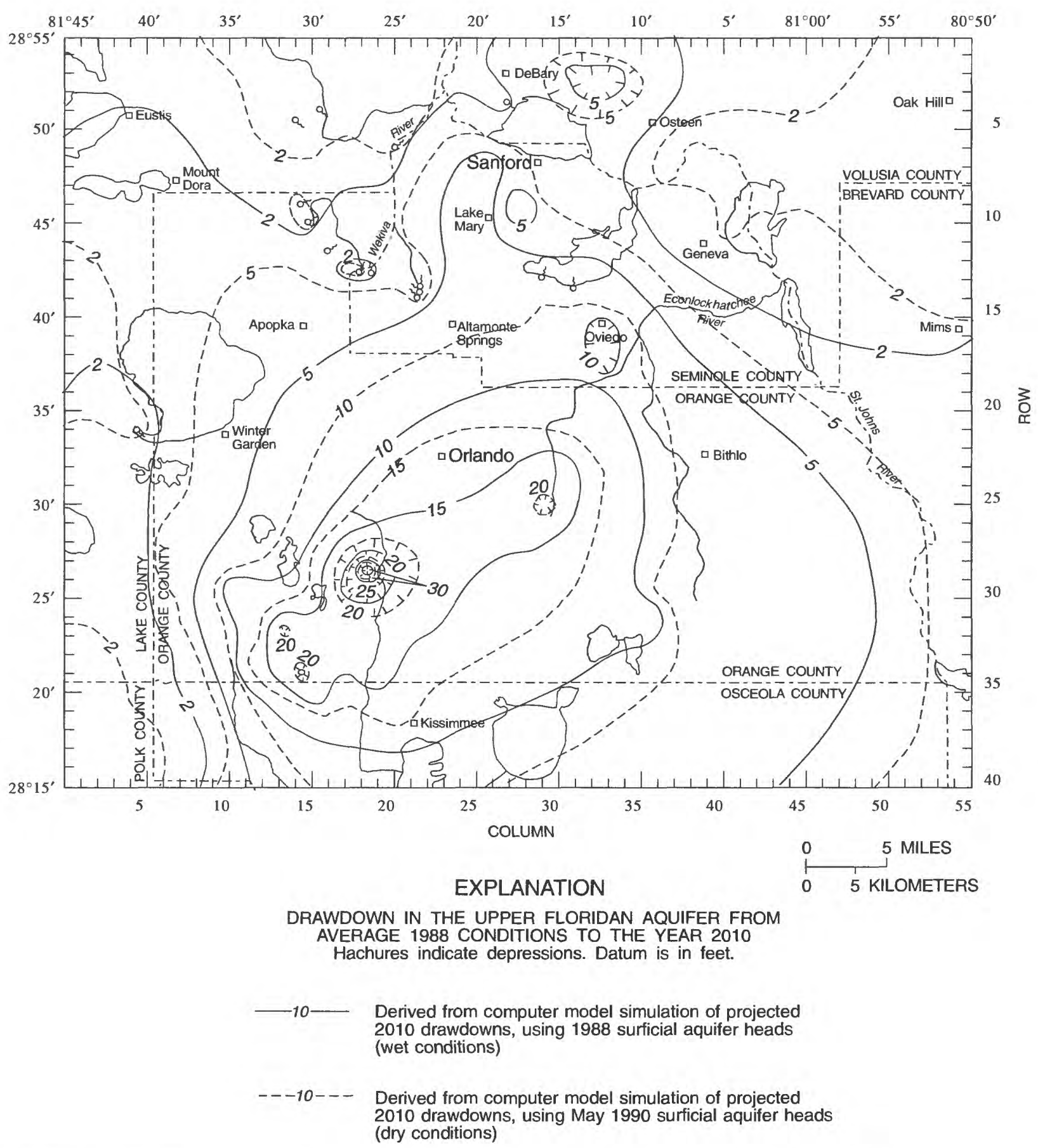

Figure 44. Simulated Upper Floridan aquifer drawdowns from 1988 to the year 2010 for projected wet and dry conditions.

from increased rates of surficial aquifer recharge ( 244 and $218 \mathrm{ft}^{3} / \mathrm{s}$ for wet and dry conditions, respectively); by reduced rates of Upper Floridan aquifer spring flow (43 and $\left.67 \mathrm{ft}^{3} / \mathrm{s}\right)$, diffuse upward leakage $(21$ and $\left.20 \mathrm{ft}^{3} / \mathrm{s}\right)$, and river discharge ( 9 and $\left.14 \mathrm{ft}^{3} / \mathrm{s}\right)$; and by increased rates of lateral inflow ( 39 and $58 \mathrm{ft}^{3} / \mathrm{s}$ ). The ultimate source of increased surficial aquifer recharge under long-term average rainfall conditions is captured evapotranspiration and reduced surface runoff.

Relatively high rates of water are discharged from the Upper Floridan aquifer to the Lower Floridan aquifer to compensate for $155 \mathrm{ft}^{3} / \mathrm{s}$ of increased Lower Floridan aquifer pumpage. In 2010, the Lower Floridan aquifer was recharged by the Upper Floridan aqui- 


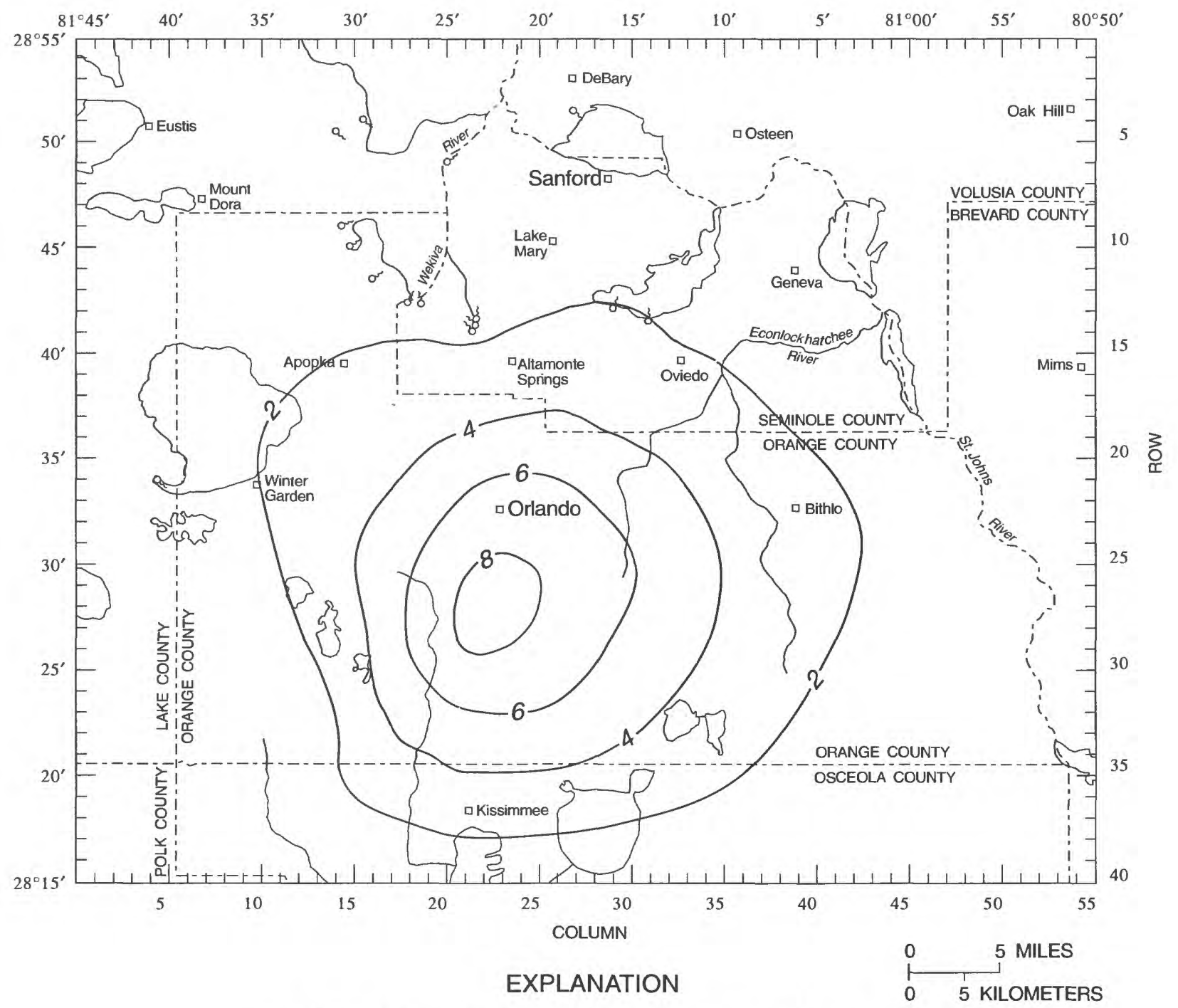

- 2 - DRAWDOWN IN FEET--Derived from computer model simulation of projected 2010 drawdowns

Figure 45. Simulated drawdown in the Upper Floridan aquifer attributed to the increase in Lower Floridan aquifer pumpage from 1988 to 2010 (wet and dry conditions).

fer at a net rate $192 \mathrm{ft}^{3} / \mathrm{s}$ for wet conditions and $177 \mathrm{ft}^{3} / \mathrm{s}$ for dry conditions, or nearly three times the net rate $\left(66 \mathrm{ft}^{3} / \mathrm{s}\right)$ simulated in 1988 . The simulated effects of diverting water from the Upper Floridan aquifer to the Lower Floridan aquifer on Upper Floridan aquifer drawdowns and spring flow have been documented in this section.

\section{Spring and Well-Field Capture Zones}

Particle-tracking techniques can be used to delineate the areas of aquifers that contribute recharge to wells and springs, and to define the paths along which injected water moves in an aquifer. MODPATH (Pollock, 1989), a USGS particle-tracking program, commonly is used in these types of analyses and was selected for this study. The program tracks "particles" of water toward or away from specified locations, based on the output from steady-state model simulations. Particle-tracking is based on advective transport and cannot be used to compute solute concentrations in ground water because the method does not account for dispersion, degradation, or retardation processes.

MODPATH was used in this study to delineate 1988 and projected 2010 recharge areas for: (1) eight 
Table 9. Simulated discharge from selected Upper Floridan aquifer springs for average 1988 and projected 2010 steady-state wet and dry conditions

[All discharge values in cubic feet per second]

\begin{tabular}{|c|c|c|c|c|c|}
\hline \multirow[b]{2}{*}{ Name of spring } & \multirow[b]{2}{*}{$\begin{array}{c}\text { Simulated } \\
\text { discharge, } \\
1988 \text { average } \\
\text { conditions }\end{array}$} & \multicolumn{2}{|c|}{ Wet conditions $^{1}$} & \multicolumn{2}{|c|}{ Dry conditions $^{2}$} \\
\hline & & $\begin{array}{c}\text { Simulated } \\
\text { discharge, } \\
2010 \\
\text { steady-state }\end{array}$ & $\begin{array}{c}\text { Percent } \\
\text { change, } \\
1988-2010\end{array}$ & $\begin{array}{c}\text { Simulated } \\
\text { discharge, } \\
2010 \\
\text { steady-state }\end{array}$ & $\begin{array}{c}\text { Percent } \\
\text { change, } \\
1988-2010\end{array}$ \\
\hline Wekiva & 69 & 61 & -13 & 56 & -23 \\
\hline Apopka & 62 & 54 & -13 & 48 & -22 \\
\hline Rock & 58 & 51 & -12 & 49 & -16 \\
\hline Sanlando, Palm, and Starbuck & 40 & 27 & -32 & 25 & -37 \\
\hline Seminole & 38 & 35 & -10 & 29 & -24 \\
\hline Messant & 16 & 15 & -6 & 14 & -12 \\
\hline Island & 7.2 & 6.6 & -8 & 6.2 & -14 \\
\hline Gemini & 6.7 & 5.6 & -16 & 5.0 & -25 \\
\hline Miami & 4.8 & 3.9 & -19 & 3.5 & -27 \\
\hline Witherington & 1.0 & 0.9 & -10 & 0.8 & -20 \\
\hline Clifton & 1.5 & 1.1 & -27 & 1.0 & -33 \\
\hline Sulphur & 1.1 & 1.0 & -9 & 0.9 & -18 \\
\hline \multirow[t]{2}{*}{ Lake Jesup } & 0.8 & 0.7 & -12 & 0.6 & -25 \\
\hline & 306 & 263 & -14 & 239 & -22 \\
\hline
\end{tabular}

Table 10. Simulated water budgets for the Upper and Lower Floridan aquifers during average 1988 and projected 2010 steady-state wet and dry conditions

[All discharge values in cubic feet per second]

\begin{tabular}{|c|c|c|c|c|c|c|c|c|}
\hline \multirow[b]{2}{*}{$\begin{array}{l}\text { Water budget } \\
\text { component }\end{array}$} & & \multirow{2}{*}{$\begin{array}{c}\text { Simulated } \\
1988 \\
\text { steady-state } \\
\text { conditions } \\
\text { (from } \\
\text { fig. 28) } \\
\text { (1) }\end{array}$} & \multicolumn{3}{|c|}{ Wet conditions $^{1}$} & \multicolumn{3}{|c|}{ Dry conditions $^{2}$} \\
\hline & & & $\begin{array}{c}\text { Simulated } \\
2010 \\
\text { steady-state } \\
\text { (2) }\end{array}$ & $\begin{array}{l}\text { Change } \\
(2)-(1)\end{array}$ & $\begin{array}{l}\text { Percent } \\
\text { change }\end{array}$ & $\begin{array}{c}\text { Simulated } \\
2010 \\
\text { steady-state } \\
\text { (3) }\end{array}$ & $\begin{array}{l}\text { Change } \\
\text { (3) - (1) }\end{array}$ & $\begin{array}{l}\text { Percent } \\
\text { change }\end{array}$ \\
\hline \multirow{4}{*}{$\begin{array}{l}\text { Recharge to the } \\
\text { Upper Floridan } \\
\text { aquifer from: }\end{array}$} & Surficial aquifer & 771 & 1,015 & 244 & 32 & 989 & 218 & 28 \\
\hline & Lateral inflow & 79 & 97 & 18 & 23 & 107 & 28 & 35 \\
\hline & Drain well; reclaimed water & 75 & 75 & 0 & 0 & 48 & -27 & -36 \\
\hline & Lower Floridan aquifer & 70 & 50 & -20 & -29 & 52 & -18 & -26 \\
\hline \multirow{6}{*}{$\begin{array}{l}\text { Discharge from } \\
\text { the Upper Flori- } \\
\text { dan aquifer to: }\end{array}$} & Wells $^{3}$ & 356 & 567 & 211 & 59 & 567 & 211 & 59 \\
\hline & Springs & 306 & 263 & -43 & -14 & 239 & -67 & -22 \\
\hline & Lower Floridan aquifer & 136 & 242 & 106 & 78 & 229 & 93 & 68 \\
\hline & River & 78 & 69 & -9 & -12 & 64 & -14 & -18 \\
\hline & Diffuse upward leakage & 64 & 43 & -21 & -33 & 44 & -20 & -31 \\
\hline & Lateral outflow & 55 & 53 & -2 & -4 & 53 & -2 & -4 \\
\hline \multirow{2}{*}{$\begin{array}{l}\text { Recharge to the } \\
\text { Lower Floridan } \\
\text { aquifer from: }\end{array}$} & Upper Floridan aquifer & 136 & 242 & 106 & 78 & 230 & 94 & 69 \\
\hline & Lateral inflow & 91 & 112 & 21 & 23 & 121 & 30 & 33 \\
\hline \multirow{3}{*}{$\begin{array}{l}\text { Discharge from } \\
\text { Lower Floridan } \\
\text { aquifer to: }\end{array}$} & Wells & 117 & 272 & 155 & 132 & 272 & 155 & 132 \\
\hline & Upper Floridan aquifer & 70 & 50 & -20 & -29 & 52 & -18 & -26 \\
\hline & Lateral outflow & 40 & 32 & -8 & -20 & 27 & -13 & -33 \\
\hline
\end{tabular}

${ }^{1}$ Simulated with 1988 surficial aquifer head array; 1988 drainage-well recharge distribution; and 1988 specified river and spring-pool heads.

${ }^{2}$ Simulated with May 1990 surficial aquifer head array; May 1990 drainage-well recharge distribution; and May 1990 specified river and spring-pool heads.

${ }^{3}$ Includes discharge from flowing wells at Wekiva Falls Resort. 
of the larger Upper Floridan aquifer springs (Messant, Seminole, Rock, Wekiva, Miami, Sanlando, Palm, and Starbuck); (2) the Cocoa well field; and (3) the proposed Orange County Eastern Regional well field (projected 2010 conditions only). MODPATH also was used to show changes caused by 2010 pumpage in the possible routes and destinations of surface water that recharges the Upper Floridan aquifer through the Lake Underhill and Lake Killarney drainage wells.

Recharge areas for selected well fields and springs were delineated by evenly distributing particles about the lateral faces of respective grid cells and then running MODPATH in the backward-tracking mode to delineate the track of simulated ground-water flow paths. Backward-tracked particle pathlines terminate at the source of the spring or well-field water. A total of 10,000 particles was distributed among appropriate cells representing Seminole, Messant, Rock, Wekiva, Miami, and the Sanlando Springs group; and 25,000 particles were distributed among the pumping wells at the Cocoa well field. The number of particles assigned to each spring and pumping well was proportional to its flow rate and sufficient to clearly delineate recharge areas. Because lateral flow was not simulated within the surficial aquifer system, the shaded areas do not include the surficial aquifer system itself but, instead, include the top of the intermediate confining unit. However, differences between recharge areas described in this report and those that would be simulated using an active surficial aquifer system probably are relatively small considering the scale of the model grid and the fact that the hydraulic conductivity of the surficial aquifer system is much smaller than the hydraulic conductivity of the Upper Floridan aquifer.

Areas contributing recharge to the Cocoa well field and the eight Upper Floridan aquifer springs in 1988 are delineated in figure 46. The contributing area shown for the Cocoa well field accounts for about 85 percent of the water discharged at the well field in 1988 and extends across south-central Orange, north-central Osceola and, to a smaller extent, northeast Polk Counties. The remaining 15 percent was contributed from areas in north Osceola and northeast Polk Counties, outside the southern model boundary. Virtually no water is shown to be captured east of the well field where water in the Upper Floridan aquifer is brackish. However, if the aquifer transmissivity east of the well field is appreciably higher than that represented by the model, then a greater potential exists for brackish water to be captured by the eastern-most sup- ply wells. The contributing area delineated in 1988 for the eight springs accounts for about 95 percent of the total spring discharge, covers about $320 \mathrm{mi}^{2}$, and extends into northwest Orange, east Lake, and southwest Seminole Counties where water in the Upper Floridan aquifer is fresh. However, it is possible that a relatively small amount of the brackish water that exists downgradient from the springs (figs. 13-15) is being captured and contributes to the gradual increase in dissolved solids concentrations (fig. 17). The grid used for this model is too coarse to simulate accurately the directions and magnitudes of the hydraulic gradients close to the springs and, thus, to draw conclusions about the sources of brackish water.

The contributing areas delineated for the Cocoa well field and Upper Floridan aquifer springs are roughly equal in size, even though the spring discharge rate in 1988 was about six times that of the Cocoa well field. This difference in contributing area per unit of aquifer discharge can be attributed to the differences in Upper Floridan aquifer recharge rates simulated in the respective contributing areas. Recharge rates in south-central Orange County are low (0-3 in/yr, fig. 39), so the contributing area must extend further from the well field to capture enough water to meet the demand. In northwest Orange and east Lake Counties, recharge rates are high (10-21 in/yr) and the capture area required per unit of spring discharge is relatively small.

Increased pumping rates in 2010 reduced the size of the area contributing recharge to the eight springs (fig. 46). As pumping rates increase, the hydraulic gradients between the springs and contributing areas are reduced as water is diverted away from the springs and toward well fields. As a result, spring flow decreases. The 2010 recharge area shown in figure 46 was simulated for wet conditions and was nearly identical to that simulated for dry conditions (not shown). This similarity indicates that the recharge area is more sensitive to changes in ground-water pumpage than to changes in surficial-aquifer head declines, at least for the range of conditions examined in this study.

The proposed OCERW is projected in 2010 to capture water from central Orange County that contributed to the Cocoa well field in 1988 (fig. 47). As a result, the projected Cocoa well field contributing area is displaced to the south and is projected to capture more water from north Osceola County and less water from central Orange County than it did in 1988. About 

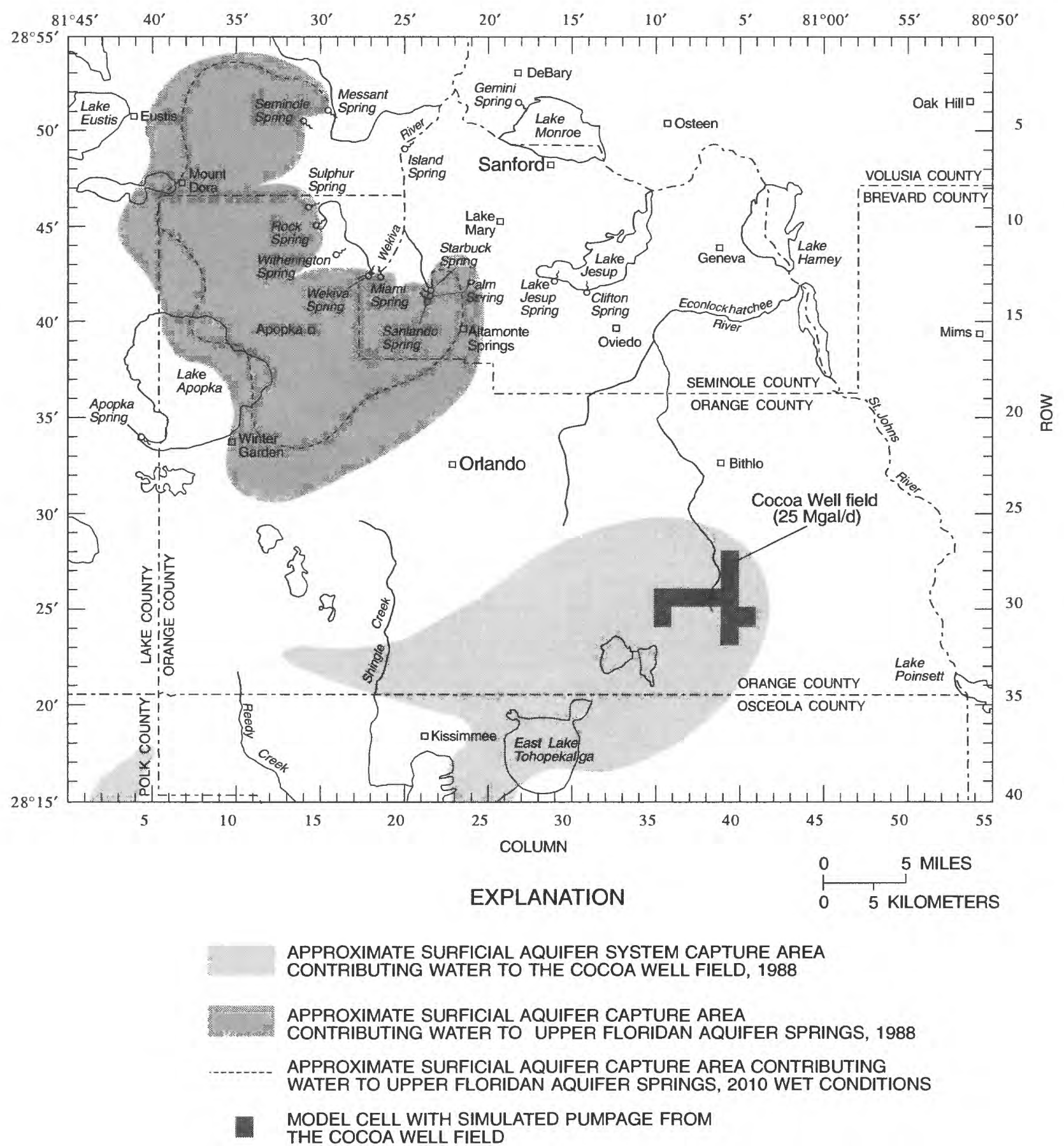

Figure 46. Approximate areas contributing water to the Cocoa well field in 1988 and to Upper Floridan aquifer springs from the base of the surficial aquifer system, average 1988 and projected 2010 wet conditions.

95 percent of the water contributing to the projected discharge rate at the OCERW is captured from the recharge area shown in figure 47 . The contributing area depicted for the Cocoa well field accounts for about 65 percent of the projected discharge rate. The remaining 35 percent is captured from areas in Osceola County south of the model boundary. Displacement of the 2010 Cocoa contributing area also may be influenced, to a smaller degree, by a shift in the center of pumpage at the well field to the south and west, by the regional effects of increased pumpage across the study area, and by errors in projected GHB heads. However, several experiments performed with various GHB head changes and distributions along the south-central 
boundary all yielded contributing areas of very similar shape and displacement. Contributing areas delineated for both 2010 wet and dry conditions at the Cocoa well field and the OCERW were nearly identical because wet and dry recharge rates in these areas are very similar.

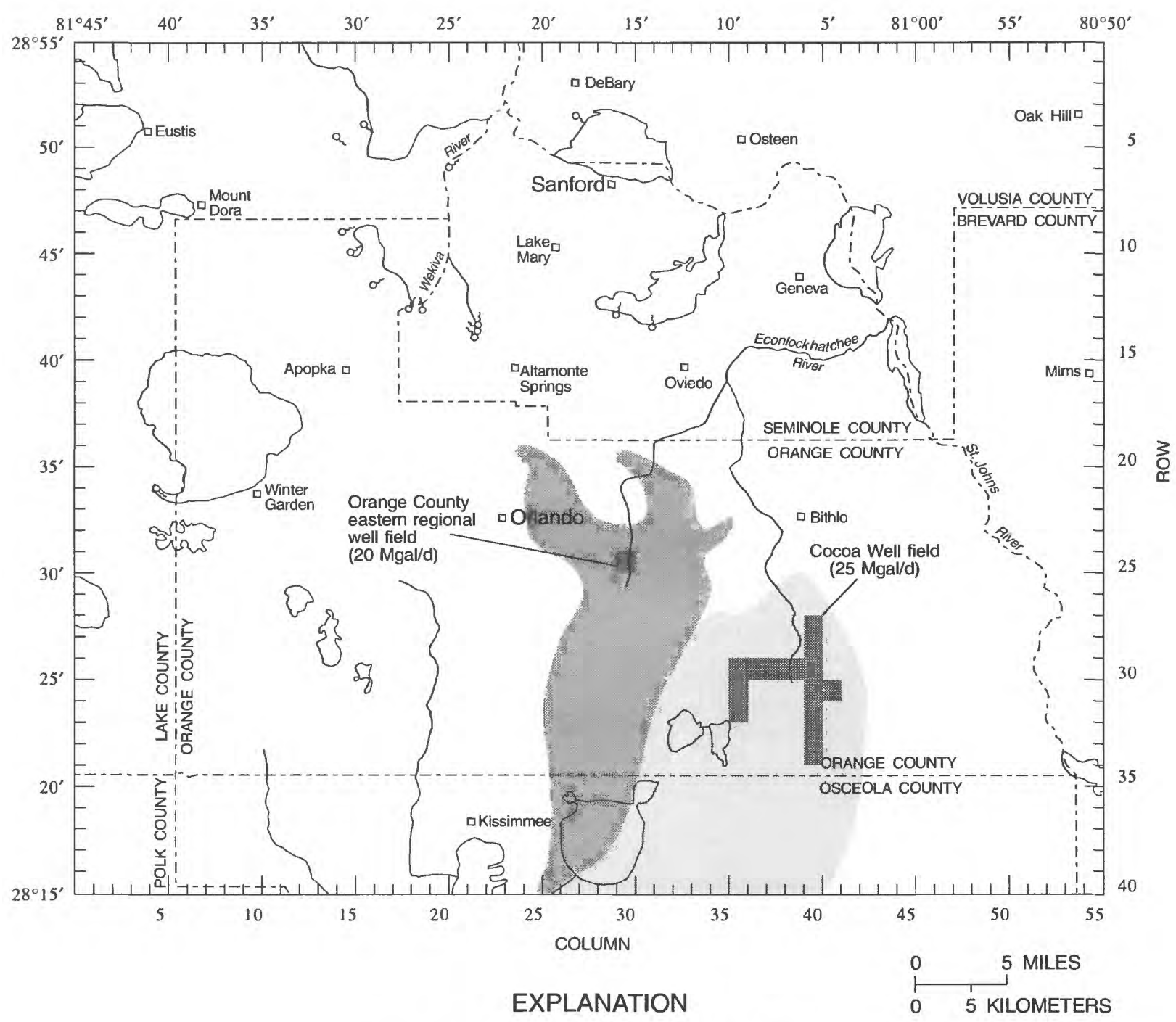

APPROXIMATE SURFICIAL AQUIFER

CAPTURE AREA CONTRIBUTING WATER

TO THE COCOA WELL FIELD

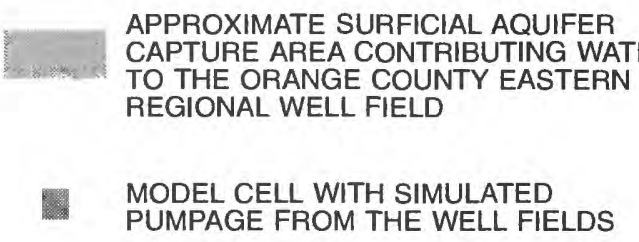

Figure 47. Approximate areas contributing water to the Cocoa well field and the Orange County eastern regional well field from the base of the surficial aquifer system, projected 2010 wet conditions. 


\section{Drainage-Well Pathlines}

The routes and destinations of surface water that recharges the Upper Floridan aquifer through the Lake Underhill and Lake Killarney drainage wells were determined by analyses of forward-tracked particles. The Lake Killarney and Lake Underhill wells were selected for analysis because of their high capacities, well-documented recharge rates $(2.1$ and $2.5 \mathrm{Mgal} / \mathrm{d}$, respectively), and their close proximity to several large municipal well fields. Between the two wells, 25,000 particles were apportioned and evenly applied to the four cell faces. The percentage of particles applied to each well that terminates at a given cell and aquifer layer can be used as an estimate of the percentage of drainage-well inflow that is discharged at that particular cell and aquifer layer. Of the inflow (particles) applied to the Lake Killarney and Lake Underhill drainage wells in 1988 , about 60 percent $(1.5 \mathrm{Mgal} / \mathrm{d})$ and 76 percent $(1.6 \mathrm{Mgal} / \mathrm{d})$, respectively, moved toward the northeast and were discharged either to the surficial aquifer system or beneath the St. Johns River in east Seminole County (fig. 48). The remaining 40 percent $(1.0 \mathrm{Mgal} / \mathrm{d})$ of inflow to the Lake Killarney well was discharged by the Sanlando Springs group. The remaining 24 percent $(0.50 \mathrm{Mgal} / \mathrm{d})$ of inflow to the Lake Underhill well was discharged by an OUC Lower Floridan aquifer well field at model row 23 , column 25 . The pathlines shown in figure 48 represent a composite of simulated paths in both the Upper and Lower Floridan aquifers.

Increased pumpage from the Lower Floridan aquifer in 2010 significantly affected the simulated flow paths and destinations of drainage-well inflow. Under 2010 wet conditions, 100 percent of the inflow applied at these two wells $(4.6 \mathrm{Mgal} / \mathrm{d})$ was captured and discharged by well fields in north-central Orange County (fig. 48). Ninety-five percent of the inflow (4.4 Mgal/d) was captured by Lower Floridan aquifer well fields and 5 percent $(0.2 \mathrm{Mgal} / \mathrm{d})$ was captured by Upper Floridan aquifer well fields. Individually, 84 percent (about $2.1 \mathrm{Mgal} / \mathrm{d}$ ) of the inflow to the Lake Killarney drainage well was captured by a Lower Floridan aquifer well field operated by the city of Winter Park (model row 20, column 27); 12 percent (0.3 Mgal/d) was captured by a second Lower Floridan aquifer well field operated by Winter Park (model row 18, column 26); and the remaining 4 percent (0.1 Mgal/d) was captured by an Upper Floridan aquifer well field operated by Orange County (model row 23, column 30). At Lake Underhill, 57 percent (about $1.2 \mathrm{Mgal} / \mathrm{d}$ ) of the surface-water inflow was captured by the same Lower Floridan aquifer well field in Winter Park that captured most of the inflow from the Lake Killarney well (model row 20, column 27); 38 percent ( $0.8 \mathrm{Mgal} / \mathrm{d})$ was captured by a Lower Floridan aquifer well field operated by the city of Orlando (model row 26, column 27); and 5 percent $(0.1 \mathrm{Mgal} / \mathrm{d})$ was captured in the Upper Floridan aquifer by the proposed OCERW (model row 25 , column 30).

The particle-capture percentages referenced above are approximate and depend on the hydrologic assumptions made during the simulations. The percentage of particles discharged to the St. Johns River and surficial aquifer system, for example, represents potential maximum amounts because the particles applied at the drainage wells were allowed to pass through cells where pumpage did not capture all of the flow entering the cell. However, these results suggest that significant increases in pumpage from the Lower Floridan aquifer probably will affect the Upper Floridan aquifer flow system in central Orange County.

\section{Limits of Model Application}

Uncertainty and possible error are inherent in the various approaches and methods used to characterize and evaluate ground-water flow systems and may ultimately be reflected in the results of model simulations. The sources of uncertainty most critical to this study are those related to (1) the spatial variation of hydrogeologic characteristics such as transmissivity and leakance; (2) conceptual model development such as defining boundary conditions and the conceptual framework; and (3) knowledge of future states of nature, such as the occurrence of droughts, and future pumpage.

The model described in this report was constructed based on a conceptually simplified flow system. In reality, flow within the Floridan aquifer system is highly complex. Vertical-flow components that exist in the aquifers and lateral-flow components in the confining units were not simulated by the model. Vertical flow within an aquifer indicates that head in the aquifer varies with depth. As a result, heads measured in monitoring wells that penetrate less than the full thickness of the aquifer may not represent the average head computed by the model. Storage changes that occur within confining units and may result in substantial local recharge to the Upper Floridan aquifer were not 


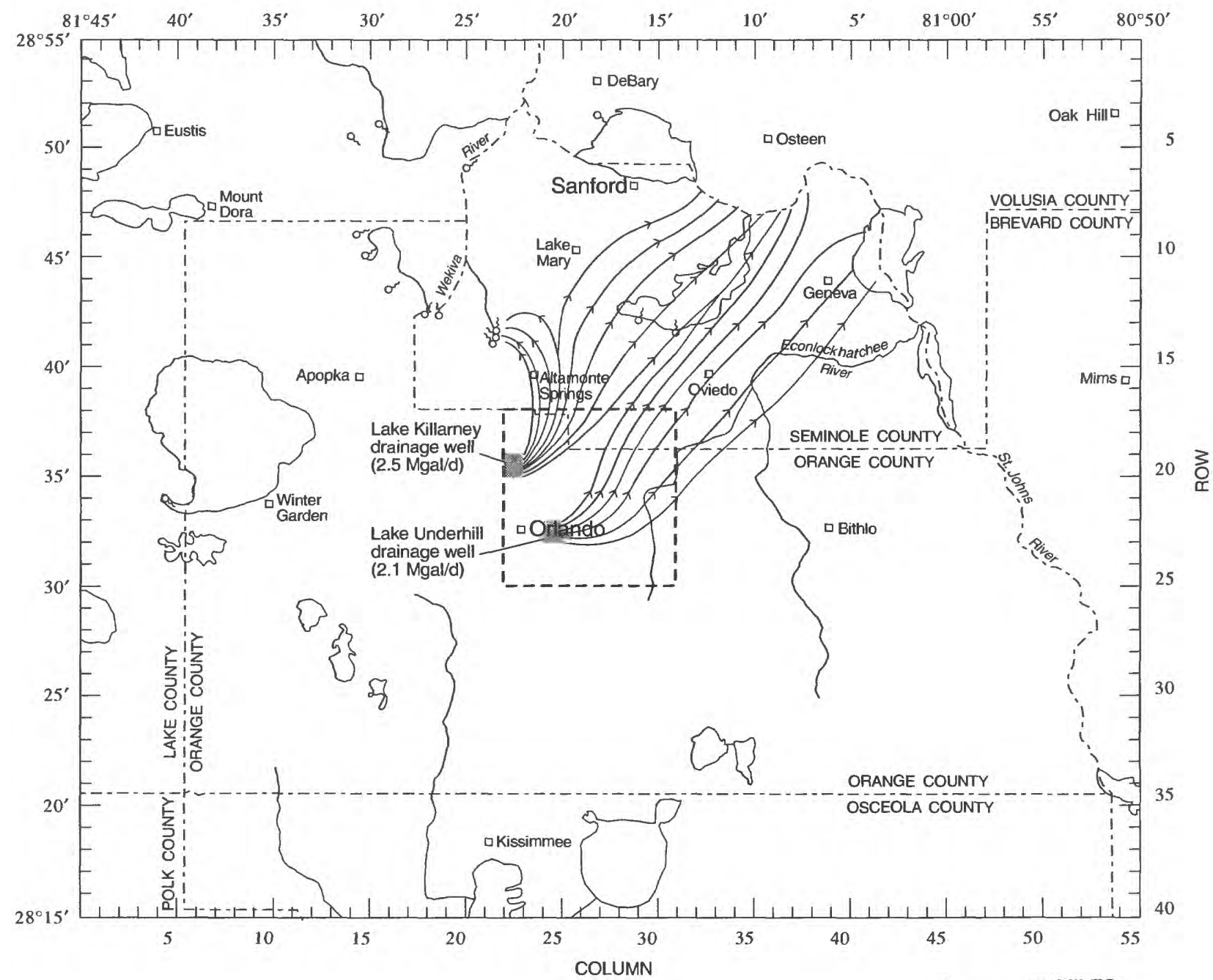

EXPLANATION
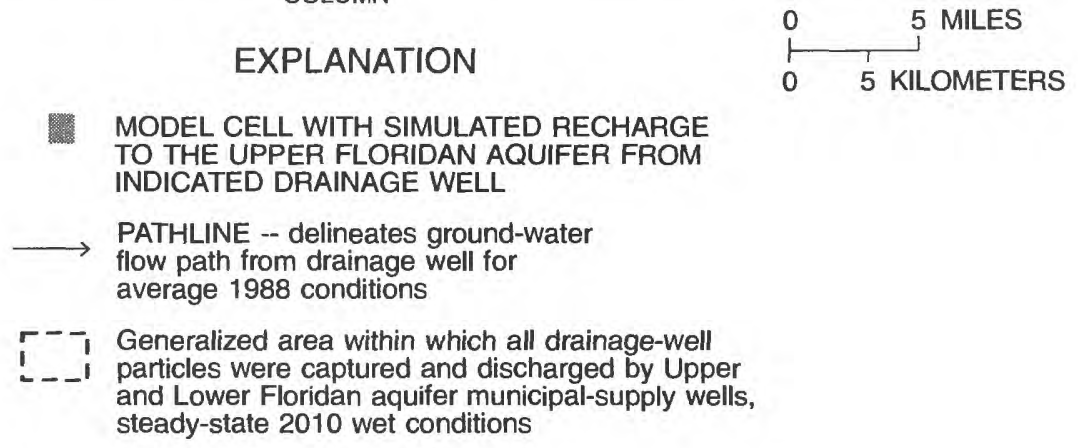

Figure 48. Simulated pathlines of ground-water flow in the Floridan aquifer system from the Lake Killarney and Lake Underhill drainage wells during average 1988 steady-state conditions, and generalized capture area for particles for projected 2010 wet conditions.

accounted for in the transient simulations. Model results are also based on the assumption that flow in the aquifers can be described by the Darcy equation. This assumption probably is valid for the grid scale used in this model. For smaller grids, however, turbulent conduit or cavernous flow in the aquifer near the springs may violate this assumption.
Comparisons of measured and simulated drawdowns are affected by the proximity of pumping and monitoring wells to one another within the same model cell. Differences increase with the coarseness of the model grid and are more pronounced in areas with steep hydraulic gradients, like those close to the larger springs and municipal-supply wells. Differences 
between measured and simulated drawdowns may also result from totaling the pumpage from several wells located within the same model cell and assigning the total to pumpage from one well at the center of the cell. In addition, the model does not account for drawdown caused by pumping-well inefficiencies or for partially penetrating pumping wells. Model simulations may underestimate drawdowns at and near these wells. Hydraulic characteristics assigned to each model cell are uniform throughout the cell and represent the average of characteristic values within the cell. These properties are actually spatially heterogeneous and can vary considerably through the $1-\mathrm{mi}^{2}$ area represented by a model cell. As a result, two pumping wells located at opposite ends of the same grid cell and pumping at the same rate can produce significantly different drawdowns.

Inaccuracies in assigned stresses and fixed heads also can affect simulated results. Municipal pumping rates used in these simulations were obtained from recorded well-field data and are considered to be reasonably accurate. Estimated agricultural and golf course withdrawals may be in error by as much as 50 percent. Even greater errors may characterize the estimates of drainage-well recharge rates and the abandoned flowing-well discharge rates used in this study. Errors in assigned water-table altitudes would affect model results, particularly in areas of west Seminole and northwest Orange Counties where the intermediate confining unit is thin and ground-water pumpage is substantial. Simulating the surficial aquifer system as an active layer would increase the reliability of predicted drawdowns in the Upper Floridan aquifer, as well as the effects of pumpage on the water table. Future modeling studies that include an active surficial aquifer system will require additional data to better define the configuration of the water table and the thickness and hydraulic properties of the system.

\section{SUMMARY AND CONCLUSIONS}

The greater Orlando metropolitan area covers about 2,500 square miles of east-central Florida and includes all of Orange and Seminole Counties and parts of Lake. Volusia, Brevard, Osceola, and Polk Counties. The area is characterized by numerous hydrologic features such as sinkholes, well-drained sandy ridges, swamps, closed-basin lakes, artesian springs, small streams, and the St. Johns River. The population in the study area has increased by more than 50 percent since 1980 and was estimated at about 1.3 million people in 1994 .

The hydrogeology of the study area is characterized by a thin, surficial-sand aquifer underlain by the thick, highly productive carbonate rocks of the Floridan aquifer system. The Floridan aquifer system is subdivided into two major permeable zones, the Upper and Lower Floridan aquifers, separated by a less permeable zone, the middle semiconfining unit. The top of the Upper Floridan aquifer dips from about 50 feet above sea level in east Lake County to more than $300 \mathrm{ft}$ below sea level in southeast Orange County. The Upper Floridan aquifer is overlain and confined throughout the study area by the intermediate confining unit, a less permeable and unconsolidated sequence of interbedded sands, silts, and clays. The thickness of the intermediate confining unit ranges from $250 \mathrm{ft}$ in southeast Orange County to less than $50 \mathrm{ft}$ in parts of Polk, Seminole, Lake, and Volusia Counties.

The Upper Floridan aquifer is primarily recharged by leakage from the surficial aquifer system. Smaller amounts of recharge occur by lateral inflow across study-area boundaries and, for developed conditions, by direct recharge from Orlando drainage wells and by the land application of reclaimed water. Primary discharge from the aquifer is by spring flow and, for developed conditions, by pumpage. Smaller quantities of water are discharged through diffuse upward leakage, leakage to the St. Johns River, lateral outflow to the Atlantic Ocean and, for developed conditions, through abandoned flowing wells. Springs identified in the study area include Wekiva, Apopka, Rock, Seminole, Messant, Sanlando, Palm, Starbuck, Gemini, Island, Miami, Witherington, Sulphur, Clifton, and Lake Jesup. These springs collectively discharged nearly as much water in 1988 (306 cubic feet per second $\left.\left(\mathrm{ft}^{3} / \mathrm{s}\right)\right)$ as was pumped from the aquifer $\left(356 \mathrm{ft}^{3} / \mathrm{s}\right)$ for municipal, commercial, industrial, and agricultural purposes.

Ground water in the Upper Floridan aquifer moves regionally from the southwest to the northeast across the study area. Potentiometric-surface altitudes range from greater than $120 \mathrm{ft}$ in north Polk County to less than $10 \mathrm{ft}$ near Lake Harney in east Seminole County. Depressed contours around the St. Johns River in east Seminole County indicate appreciable aquifer discharge, possibly from undocumented springs. Ground-water flow velocities generally are higher in the Upper Floridan aquifer than in the Lower 


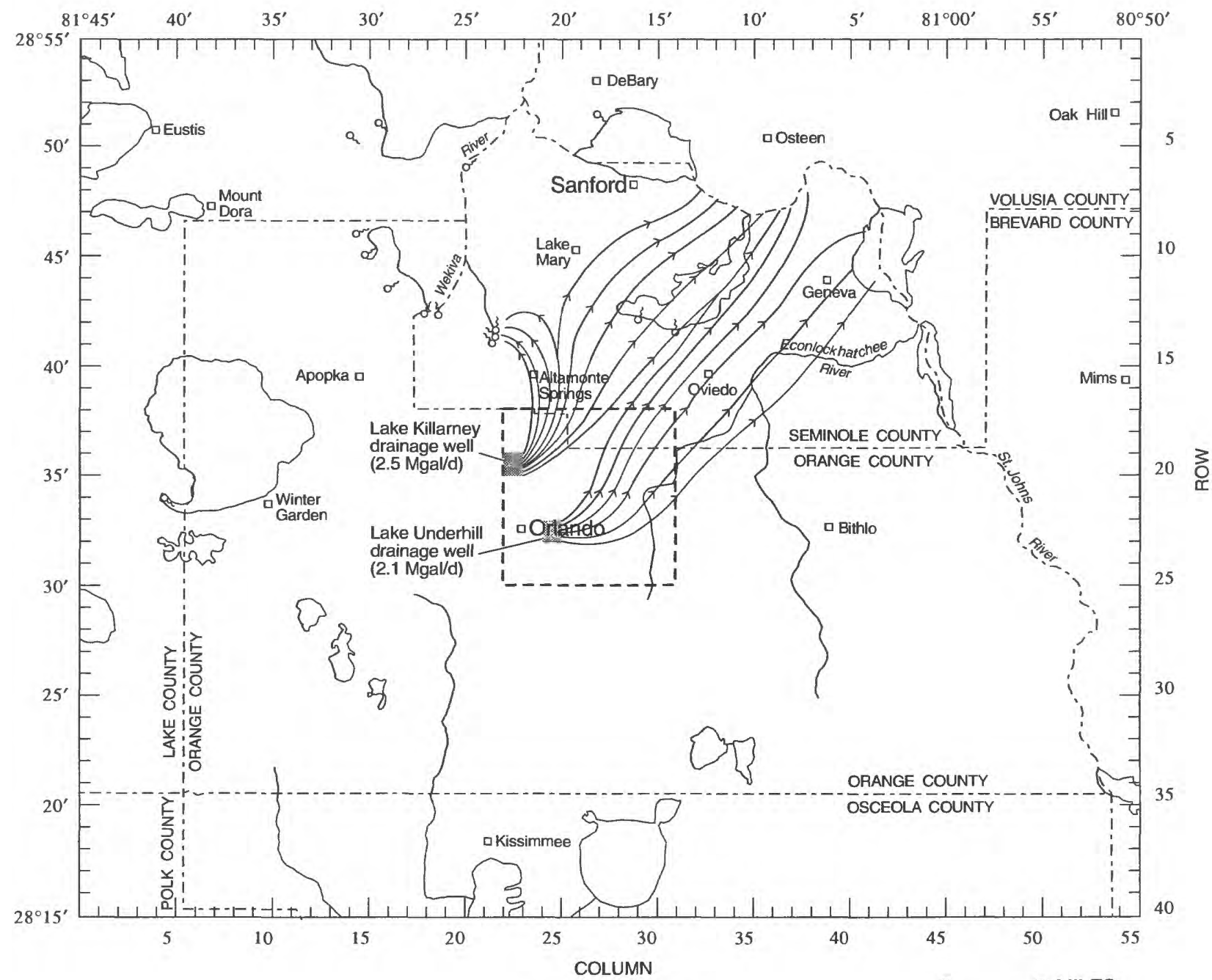

EXPLANATION
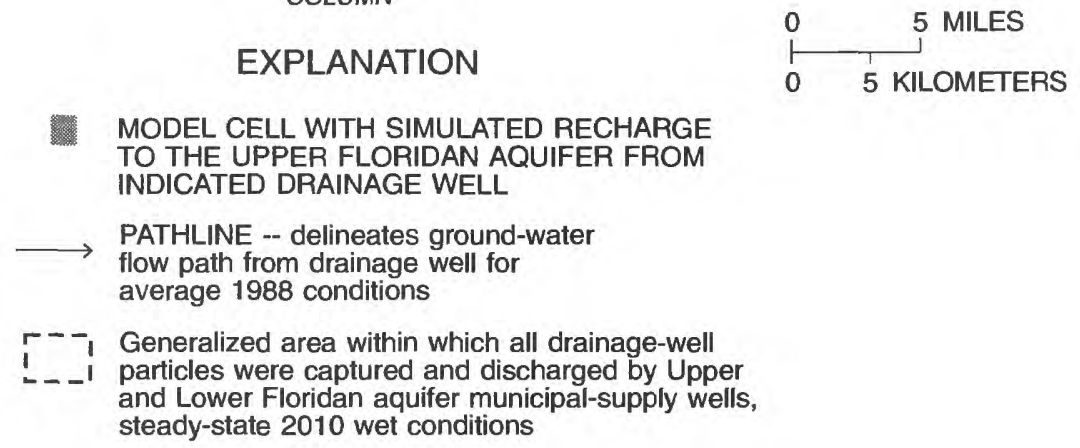

Figure 48. Simulated pathlines of ground-water flow in the Floridan aquifer system from the Lake Killarney and Lake Underhill drainage wells during average 1988 steady-state conditions, and generalized capture area for particles for projected 2010 wet conditions.

accounted for in the transient simulations. Model results are also based on the assumption that flow in the aquifers can be described by the Darcy equation. This assumption probably is valid for the grid scale used in this model. For smaller grids, however, turbulent conduit or cavernous flow in the aquifer near the springs may violate this assumption.
Comparisons of measured and simulated drawdowns are affected by the proximity of pumping and monitoring wells to one another within the same model cell. Differences increase with the coarseness of the model grid and are more pronounced in areas with steep hydraulic gradients, like those close to the larger springs and municipal-supply wells. Differences 
between measured and simulated drawdowns may also result from totaling the pumpage from several wells located within the same model cell and assigning the total to pumpage from one well at the center of the cell. In addition, the model does not account for drawdown caused by pumping-well inefficiencies or for partially penetrating pumping wells. Model simulations may underestimate drawdowns at and near these wells. Hydraulic characteristics assigned to each model cell are uniform throughout the cell and represent the average of characteristic values within the cell. These properties are actually spatially heterogeneous and can vary considerably through the $1-\mathrm{mi}^{2}$ area represented by a model cell. As a result, two pumping wells located at opposite ends of the same grid cell and pumping at the same rate can produce significantly different drawdowns.

Inaccuracies in assigned stresses and fixed heads also can affect simulated results. Municipal pumping rates used in these simulations were obtained from recorded well-field data and are considered to be reasonably accurate. Estimated agricultural and golf course withdrawals may be in error by as much as 50 percent. Even greater errors may characterize the estimates of drainage-well recharge rates and the abandoned flowing-well discharge rates used in this study. Errors in assigned water-table altitudes would affect model results, particularly in areas of west Seminole and northwest Orange Counties where the intermediate confining unit is thin and ground-water pumpage is substantial. Simulating the surficial aquifer system as an active layer would increase the reliability of predicted drawdowns in the Upper Floridan aquifer, as well as the effects of pumpage on the water table. Future modeling studies that include an active surficial aquifer system will require additional data to better define the configuration of the water table and the thickness and hydraulic properties of the system.

\section{SUMMARY AND CONCLUSIONS}

The greater Orlando metropolitan area covers about 2,500 square miles of east-central Florida and includes all of Orange and Seminole Counties and parts of Lake, Volusia, Brevard, Osceola, and Polk Counties. The area is characterized by numerous hydrologic features such as sinkholes, well-drained sandy ridges, swamps, closed-basin lakes, artesian springs, small streams, and the St. Johns River. The population in the study area has increased by more than 50 percent since 1980 and was estimated at about 1.3 million people in 1994.

The hydrogeology of the study area is characterized by a thin, surficial-sand aquifer underlain by the thick, highly productive carbonate rocks of the Floridan aquifer system. The Floridan aquifer system is subdivided into two major permeable zones, the Upper and Lower Floridan aquifers, separated by a less permeable zone, the middle semiconfining unit. The top of the Upper Floridan aquifer dips from about 50 feet above sea level in east Lake County to more than $300 \mathrm{ft}$ below sea level in southeast Orange County. The Upper Floridan aquifer is overlain and confined throughout the study area by the intermediate confining unit, a less permeable and unconsolidated sequence of interbedded sands, silts, and clays. The thickness of the intermediate confining unit ranges from $250 \mathrm{ft}$ in southeast Orange County to less than $50 \mathrm{ft}$ in parts of Polk, Seminole, Lake, and Volusia Counties.

The Upper Floridan aquifer is primarily recharged by leakage from the surficial aquifer system. Smaller amounts of recharge occur by lateral inflow across study-area boundaries and, for developed conditions, by direct recharge from Orlando drainage wells and by the land application of reclaimed water. Primary discharge from the aquifer is by spring flow and, for developed conditions, by pumpage. Smaller quantities of water are discharged through diffuse upward leakage, leakage to the St. Johns River, lateral outflow to the Atlantic Ocean and, for developed conditions, through abandoned flowing wells. Springs identified in the study area include Wekiva, Apopka, Rock, Seminole, Messant, Sanlando, Palm, Starbuck, Gemini, Island, Miami, Witherington, Sulphur, Clifton, and Lake Jesup. These springs collectively discharged nearly as much water in 1988 (306 cubic feet per second $\left.\left(\mathrm{ft}^{3} / \mathrm{s}\right)\right)$ as was pumped from the aquifer $\left(356 \mathrm{ft}^{3} / \mathrm{s}\right)$ for municipal, commercial, industrial, and agricultural purposes.

Ground water in the Upper Floridan aquifer moves regionally from the southwest to the northeast across the study area. Potentiometric-surface altitudes range from greater than $120 \mathrm{ft}$ in north Polk County to less than $10 \mathrm{ft}$ near Lake Harney in east Seminole County. Depressed contours around the St. Johns River in east Seminole County indicate appreciable aquifer discharge, possibly from undocumented springs. Ground-water flow velocities generally are higher in the Upper Floridan aquifer than in the Lower 
Floridan aquifer, particularly in areas of northwest Orange and east Lake Counties where recharge to the Upper Floridan aquifer moves along relatively short flow paths and is captured by springs. Velocities are relatively low in areas of east Seminole County around Lake Harney where hydraulic gradients are small and aquifer transmissivity is low.

Upper Floridan aquifer water levels and spring flow have been affected by extensive ground-water development. Relative to the 1930 's, drawdowns induced by 1988 pumpage ( 305 million gallons per day (Mgal/d) from the Floridan aquifer system) ranged from less than $5 \mathrm{ft}$ in the more rurally populated areas of east Lake, south Volusia, east Seminole, north Brevard, and northeast Polk Counties, to about 10 to $20 \mathrm{ft}$ across central Orange and north Osceola Counties. Spring flow was reduced from about 360 to $306 \mathrm{ft}^{3} / \mathrm{s}$.

Water in the Floridan aquifer system generally is of a calcium-magnesium bicarbonate type. The chemical quality of water in the Upper Floridan aquifer generally varies with proximity to recharge and discharge areas. Low concentrations of dissolved solids (less than 500 milligrams per liter $(\mathrm{mg} / \mathrm{L})$ ), chloride (less than $100 \mathrm{mg} / \mathrm{L}$ ), and sulfate (less than $50 \mathrm{mg} / \mathrm{L}$ ) generally occur in recharge areas that are infiltrated by fresh rainwater. The most highly mineralized water occurs in discharge areas beneath the St. Johns River where concentrations of dissolved solids, chloride, and sulfate exceed $1,000,4,000$, and $250 \mathrm{mg} / \mathrm{L}$, respectively.

Based on ionic composition, water sampled in May 1993 from 10 Upper Floridan aquifer springs was categorized as one of 3 types. Water from Wekiva, Rock, Sanlando, Palm, Starbuck, Miami, and Witherington Springs is a calcium bicarbonate type water, low in dissolved solids, that results from the dissolution of calcium carbonate (limestone). Water sampled from Seminole and Messant Springs is a more highly mineralized, calcium sulfate type water that results from dissolution of a calcium sulfate aquifer matrix. The sodium chloride type water discharged at Gemini Springs results less from aquifer-matrix dissolution, but more from mixing with entrapped relict seawater or from upwelling of brackish water through fractures.

Water discharged from Upper Floridan aquifer springs has become more mineralized with time. From 1956 to 1993 , the specific conductance of water discharged at Wekiva Springs has steadily increased from about 225 to 300 microsiemens per centimeter. The concentrations of dissolved solids, chloride, and sul- fate in water sampled in May 1993 at each of the 10 springs all exceeded respective mean concentrations that were calculated from previous sampling events.

The U.S. Geological Survey three-dimensional finite-difference ground-water flow model MODFLOW was used to simulate flow in the Floridan aquifer system within the study area. The uniform model grid consists of 40 rows and 55 columns, with cell dimensions of 5,320 by $6,050 \mathrm{ft}$. The model was vertically discretized into three layers-the surficial aquifer, the Upper Floridan aquifer, and the Lower Floridan aquifer. The surficial aquifer system was represented by an inactive specified-head array that provides recharge to, and receives discharge from, the Upper Floridan aquifer. The Upper and Lower Floridan aquifers were each represented by a single active layer. Each of the two confining units were represented by an array of variable leakance values. Several MODFLOW packages were used to provide volumetric budgets for different components of the flow system. Pumpage from the aquifer was simulated by the well package; lateral flow across model boundaries by the General-Head Boundary package; discharge from Upper Floridan aquifer springs by the Drain package; discharge from the Upper Floridan aquifer to the St. Johns River system by the River package; and recharge to the aquifer from Orlando drainage wells and reclaimed water by the Recharge package.

The calibrated model simulated the (a) steadystate configuration of the Upper Floridan aquifer potentiometric surface as estimated prior to extensive ground-water development, (b) steady-state water levels measured in 142 Upper Floridan aquifer monitoring wells in 1988 (average absolute error of $1.8 \mathrm{ft}$ ), (c) steady-state spring flow measured at 15 Upper Floridan aquifer springs in $1988\left(306 \mathrm{ft}^{3} / \mathrm{s}\right.$ simulated and measured), (d) water-level declines measured in the Upper Floridan aquifer from January to May 1990 at 12 monitoring wells equipped with continuous water-level recorders and (e) drawdowns measured in 134 Upper Floridan aquifer monitoring wells between 1988 and May 1990 (58 percent of simulated drawdowns were within plus or minus 25 percent of measured drawdowns).

Relative to predevelopment conditions, about half of the water pumped from the Floridan aquifer system in $1988\left(473 \mathrm{ft}^{3} / \mathrm{s}\right)$ was accounted for by increased recharge from the surficial aquifer system $\left(231 \mathrm{ft}^{3} / \mathrm{s}\right)$. The balance of pumpage was accounted for 
by recharge from the Orlando drainage wells and reclaimed water $\left(75 \mathrm{ft}^{3} / \mathrm{s}\right)$ and by reductions in spring flow $\left(50 \mathrm{ft}^{3} / \mathrm{s}\right)$, diffuse upward leakage $\left(44 \mathrm{ft}^{3} / \mathrm{s}\right)$, lateral outflow $\left(32 \mathrm{ft}^{3} / \mathrm{s}\right)$, and river discharge $\left(18 \mathrm{ft}^{3} / \mathrm{s}\right)$. A relatively small increase in lateral inflow $\left(23 \mathrm{ft}^{3} / \mathrm{s}\right)$ was induced by 1988 pumpage. Prior to development, the net flow rate of water exchanged between the Upper and Lower Floridan aquifers was relatively small (about $16 \mathrm{ft}^{3} / \mathrm{s}$ ) and flow was upward from the Lower to the Upper Floridan aquifer. The net flow rate increased to $66 \mathrm{ft}^{3} / \mathrm{s}$ in 1988 and flow was from the Upper to the Lower Floridan aquifer. The reversal and increase in the net flow rate can be attributed to the drawdowns induced in the Lower Floridan aquifer by 1988 pumpage and from mounding of the Upper Floridan aquifer potentiometric surface by recharge from the Orlando drainage wells.

A storage coefficient of $1 \times 10^{-3}$ provided the best match of water-level declines measured in the Upper Floridan aquifer between January and May 1990 at the 12 monitoring wells equipped with continuous water-level recorders. This storage value probably accounts for the combined effects of water released from storage in both the Upper Floridan aquifer and the intermediate confining unit. The high transmissivity and low storativity of the Floridan aquifer system result in a large diffusivity (transmissivity divided by the storage coefficient), suggesting that the system can be expected to equilibrate rapidly to changes in stress. Discharge simulated at Wekiva, Rock, Sanlando, Palm, Starbuck, Seminole, Messant, and Miami Springs in May 1990 totaled $184 \mathrm{ft}^{3} / \mathrm{s}$ compared to the measured total of $176 \mathrm{ft}^{3} / \mathrm{s}$. It is possible that declines in surficial aquifer heads, estimated largely from lake-level data, were underestimated for the transient period. Also, pumpage from nursery farms concentrated in northwest Orange and east Lake Counties may have been underestimated. Finally, rural-domestic pumpage was not included in the model.

Calibrated transmissivity values ranged from 10,000 to greater than 400,000 feet squared per day $\left(\mathrm{ft}^{2} / \mathrm{d}\right.$ ) for the Upper Floridan aquifer, and from 5,000 to $600,000 \mathrm{ft}^{2} / \mathrm{d}$ for the Lower Floridan aquifer. Calibrated values for a given area usually exceeded transmissivities determined by aquifer tests. Lowest Upper Floridan aquifer transmissivities occur in northeast Polk County and in discharge areas beneath the St.Johns River and Reedy Creek. Highest calibrated transmissivities occur in northwest, central, and east Orange County and in east-central Lake County.
Transmissivity of the Lower Floridan aquifer is less well known, but smallest calibrated values occur in north and east Seminole, north Brevard, and southwest Volusia Counties where the freshwater-saltwater interface is nearer the top of the aquifer. The highest calibrated transmissivity occurs in central Orange County, where aquifer-test analyses have yielded similarly high values. Calibrated intermediate confining unit leakance values ranged from $1 \times 10^{-5} / \mathrm{d}$ to $4 \times 10^{-3} / \mathrm{d}$ and were consistently lower than values yielded from aquifer tests. Leakance values are highest in northeast Polk, east Lake, and parts of west Orange, west Seminole, and southwest Volusia Counties. The confining unit in these areas is thin or riddled with sinkholes. Lowest leakance values occur in southeast Orange and northeast Osceola Counties where the confining unit is thickest. A leakance value of $5 \times 10^{-5} / \mathrm{d}$ was specified for the middle semiconfining unit across most of the study area.

Recharge from the surficial aquifer system to the Upper Floridan aquifer occurs over about 75 percent of the study area. Simulated recharge rates in 1988 ranged from less than 1 to about 21 inches per year (in/yr), with an average of $4.2 \mathrm{in} / \mathrm{yr}$ over the study area. Recharge rates of $10 \mathrm{in} / \mathrm{yr}$ or greater occur over about 16 percent of the study area, including parts of east Lake, west Orange, west Seminole, and southwest Volusia Counties. These areas are characterized by either karstic topography or by a relatively thin intermediate confining unit. Low rates of recharge (less than $3 \mathrm{in} / \mathrm{yr}$ ) occur across central Orange, north Osceola, and south Volusia Counties where the intermediate confining unit is thick or where the water table is relatively close to land surface (increasing losses to evapotranspiration). Discharge from the Upper Floridan aquifer to the surficial aquifer system by diffuse upward leakage was simulated beneath the St. Johns River and adjacent low-lying areas, downgradient from Upper Floridan aquifer springs and beneath the Wekiva River, beneath Reedy Creek and the western half of Lake Apopka, and in low-lying areas of south Volusia County. Simulated discharge rates typically ranged from 1 to $4 \mathrm{in} / \mathrm{yr}$, but were substantially higher in areas beneath the St. Johns River just upstream from and in the southwest part of Lake Harney $\left(24 \mathrm{ft}^{3} / \mathrm{s}\right.$ or $\left.282 \mathrm{in} / \mathrm{yr}\right)$, between Lake Harney and Lake Jesup ( $11 \mathrm{ft}^{3} / \mathrm{s}$ or $129 \mathrm{in} / \mathrm{yr}$ ), and at the confluence of the St. Johns and Wekiva Rivers $\left(9 \mathrm{ft}^{3} / \mathrm{s}\right.$ or $106 \mathrm{in} / \mathrm{yr}$ ). Undocumented Upper Floridan aquifer springs may exist in these areas. 
Kimrey, J.O., 1978, Preliminary appraisal of the geohydrologic aspects of drainage wells, Orlando area, central Florida: U.S. Geological Survey Water-Resources Investigations 78-37, $24 \mathrm{p}$.

1990, Potential for ground-water development in central Volusia County, Florida: U.S. Geological Survey Water-Resources Investigations Report 90-4010, $31 \mathrm{p}$.

Knochenmus, D.D., 1975, Hydrologic concepts of artificially recharging the Floridan aquifer in eastern Orange County, Florida - a feasibility study: Florida Bureau of Geology Report of Investigations No. 72, $36 \mathrm{p}$.

Knochenmus, D.D., and Beard, M.E., 1971, Evaluation of the quantity and quality of the water resources of Volusia County, Florida: Florida Bureau of Geology Report of Investigations No. 57, 59 p.

Knochenmus, D.D., and Hughes, G.H., 1976, Hydrology of Lake County, Florida: U.S. Geological Survey Water-Resources Investigations 76-72, $100 \mathrm{p}$.

Leake, S.A., Leahy, P.P., and Navoy, A.S., 1994, Documentation of a computer program to simulate transient leakage from confining units using the modular finite-difference ground-water flow model: U.S. Geological Survey Open-File Report 94-59, $70 \mathrm{p}$.

Lichtler, W.F., 1972, Appraisal of water resources in the east-central Florida region: Florida Bureau of Geology Report of Investigations No. 61, 52 p.

Lichtler, W.F., Anderson, Warren, and Joyner, B.F., 1968, Water resources of Orange County, Florida: Florida Division of Geology Report of Investigations No. 50, $150 \mathrm{p}$.

Lohman, S.W., 1972, Ground-water hydraulics: U.S. Geological Survey Professional Paper 708, $70 \mathrm{p}$.

McDonald, M.G., and Harbaugh, A.W., 1988, A modular three-dimensional finite-difference ground-water flow model: U.S. Geological Survey Techniques of Water-Resources Investigations, book 6, chap. A1, $576 \mathrm{p}$.

McGurk, B., Bond, P., and Mehan, D., 1989, Hydrogeologic and lithologic characteristics of the surficial sediments in Volusia County, Florida: St. Johns River Water Management District Technical Publication SJ 89-7, 38 p.

Miller, J.A., 1986, Hydrogeologic framework of the Floridan aquifer system in Florida and in parts of Georgia, South Carolina, and Alabama: U.S. Geological Survey Professional Paper 1403-B, 91 p., and 33 pls.

Murray, L.C., 1990, Potentiometric surface of the Upper Floridan aquifer in the St. Johns River Water Management District and vicinity, May 1990: U.S. Geological Survey Open-File Report 90-557, 1 map.

Parkhurst, D.L., Thorstenson, D.C., and Plummer, L.N., 1980, PHREEQUE--A computer program for geochemical calculations: U.S. Geological Survey Water-Resources Investigations Report 80-96, 210 p.
Phelps, G.G., 1990, Geology, hydrology, and water quality of the surficial aquifer system in Volusia County, Florida: U.S. Geological Survey Water-Resources Investigations Report 90-4069, $67 \mathrm{p}$.

Phelps, G.G., and Rohrer, K.P., 1987, Hydrology in the area of a freshwater lens in the Floridan aquifer system, northeast Seminole County, Florida: U.S. Geological Survey Water-Resources Investigations Report 86-4078, $74 \mathrm{p}$.

Phelps, G.G., and Schiffer, D.M., 1996, Geohydrology and potential for upward movement of saline water in the Cocoa well field, east Orange County, Florida: U.S. Geological Survey Open-File Report 95-736, 38 p.

Pirkle, B.A., 1971, Offset course of the St. Johns River, Florida: Southeastern Geology, v. 13, no.1, p. 39-59.

Planert, Michael, and Aucott, W.R., 1985, Water-supply potential of the Floridan aquifer in Osceola, eastern Orange and southwestern Brevard Counties, Florida: U.S. Geological Survey Water-Resources Investigations Report 84-4135, $69 \mathrm{p}$.

Pollock, D.W., 1989, Documentation of computer programs to compute and display pathlines using results from the U.S. Geological Survey modular three-dimensional finite-difference ground water-flow model: U.S. Geological Survey Open-File Report 89-381, 188 p.

Post, Buckley, Schuh, and Jernigan, Inc., 1989, Western Regional Water System-aquifer testing and wellfield evaluation: Volume 1, prepared for the Board of County Commissioners, Public Utilities Division, Orange County, Florida.

Post, Buckley, Schuh, and Jernigan, Inc., 1990, Floridan aquifer testing and analysis, Bull Creek Wildlife Management Area, Osceola County, Vol. 1, report submitted to Orange County Public Utilities.

Putnam, A.L., 1975, Summary of hydrologic conditions and effects of Walt Disney World development in the Reedy Creek Improvement District, 1966-1973: Florida Bureau of Geology Report of Investigations No. $79,115 \mathrm{p}$.

Rodis, H.G., 1989, Potentiometric surface of the Upper Floridan aquifer in the St. Johns River Water Management District and vicinity, September 1988: U.S. Geological Survey Open-File Report 89-65, 1 map.

Rosenau, J.C., Faulkner, G.L., Hendry, C.W., Jr., and Hull, R.W., 1977, Springs of Florida: Florida Bureau of Geology Bulletin No. 31 (revised), 461 p.

Rutledge, A.T., 1982, Hydrology of the Floridan aquifer in northwest Volusia County, Florida: U.S. Geological Survey Water-Resources Investigations Open-File Report 82-108, 116 p, and 1 sheet.

-1985, Ground-water hydrology of Volusia County, Florida, with emphasis on occurrence and movement of brackish water: U.S. Geological Survey Water-Resources Investigations Report 84-4206, 84 p. 
Schiner, G.R., 1988, Potentiometric surface of the Upper Floridan aquifer in the St. Johns River Water Management District and vicinity, Florida, May 1988: U.S. Geological Survey Open-File Report 88-460, 1 sheet. 1993, Geohydrology of Osceola County, Florida: U.S. Geological Survey Water-Resources Investigations Report 92-4076, $68 \mathrm{p}$.

Shaw, J.E., and Trost, S.M., 1984, Hydrogeology of the Kissimmee Planning Area: South Florida Water Management District Technical Publication 84-1, Parts I and II, $235 \mathrm{p}$.

Singleton, Vince, 1988, Benchmark Farms Program summary of agricultural pumpage data through 1988: St. Johns River Water Management District Special Publication SJ 88-SP2.

Skipp, David, 1988, Ground-water flow model of Brevard, Indian River, Orange, Osceola, and Seminole Counties, Florida: St. Johns River Water Management District Technical Publication 88-2, $87 \mathrm{p}$.

Spechler, R.M., 1994, Saltwater intrusion and quality of water in the Floridan aquifer system, northeastern Florida: U.S. Geological Survey Water-Resources Investigations Report 92-4174, 76 p.

Steele, Crystal, 1991, Annual report on abandoned artesian wells: St. Johns River Water Management District Special Publication SJ 91-SP7, $110 \mathrm{p}$.

Stewart, H.G., Jr., 1966, Ground-water resources of Polk County, Florida: Florida Geological Survey Report of Investigations No. 44, $170 \mathrm{p}$.

Stringfield, V.T., 1933, Ground water investigations in Florida: Florida Geological Survey Bulletin 11, 33 p.

1936, Artesian water in the Floridan peninsula: U.S. Geological Survey Water-Supply Paper 773-C, 195 p.

Szell, G.P., 1993, Aquifer characteristics in the St. Johns River Water Management District: St. Johns River Water Management District Technical Publication SJ 93-1, $495 \mathrm{p}$.

Taylor, G.F., 1993, Inventory of drainage wells and potential sources of contaminants to drainage-well inflow in southwest Orlando, Orange County, Florida: U.S. Geological Survey Water-Resources Investigations Report 93-4061, 1 sheet.

Tibbals, C.H., 1977, Availability of ground water in Seminole County and vicinity, Florida: U.S. Geological Survey Water-Resources Investigations 76-97, 15 p., and 4 sheets.
1981, Computer simulation of the steady-state flow system of the Tertiary limestone (Floridan) aquifer system in east-central Florida: U.S. Geological Survey Water-Resources Investigations Open-File Report 81-681, $31 \mathrm{p}$.

1990, Hydrology of the Floridan aquifer system in east-central Florida: U.S. Geological Survey Professional Paper 1403-E, 98 p.

Tibbals, C.H., and Frazee, J.M., 1976, Ground-water hydrology of the Cocoa well-field area, Orange County, Florida: U.S. Geological Survey Open-File Report 75-676, $67 \mathrm{p}$.

Tibbals, C.H., and Grubb, H.F., 1982, Aquifer-test results, Green Swamp area, Florida: U.S. Geological Survey Water-Resources Investigations 82-35, 28 p.

Toth, David, Rohrer, K.P., and Munch, D.A., 1989, Water quality assessment of the Floridan aquifer in the Wekiva River basin of Orange, Lake, and Seminole Counties: St. Johns River Water Management District Technical Publication 89-5, $46 \mathrm{p}$.

U.S. Engineer's Office, 1946, Ground water elevations and rainfall in central Florida, November 1935 to January 1946: Jacksonville, Florida.

U.S. Geological Survey, 1993, Water resources data for Florida, water year 1993, v. 1B. Northeast Florida ground water, $296 \mathrm{p}$.

Unklesbay, A.G., 1944, Ground water conditions in Orlando and vicinity, Florida: Florida Geological Survey Report of Investigations No. 5, 75 p.

Vecchioli, John, Tibbals, C.H., Duerr, A.D., and Hutchinson, C.B., 1990, Ground-water recharge in Florida-A pilot study in Okaloosa. Pasco, and Volusia Counties: U.S. Geological Survey Water-Resources Investigations Report 90-4195, 16 p.

Vernon, R., 1951, Geology of Citrus and Levy Counties, Florida: Florida Bureau of Geology Bulletin No. 33.

Watkins, F.A., Jr., 1977, Effectiveness of pilot connector well in artificial recharge of the Floridan aquifer, west Orange County, Florida: U.S. Geological Survey Water-Resources Investigations 77-112, 28 p.

Wyrick, G.G., 1960, The ground-water resources of Volusia County, Florida: Florida Geological Survey Report of Investigations No. 22, 65 p.

Yovaish Engineering Sciences Inc., 1994, Completion report for Lower Floridan aquifer test well, Oviedo water treatment plant, the City of Oviedo, Florida (PN 94-040.1), report submitted to the St. Johns River Water Management District. 
APPENDIXES 
Appendix A. Index to wells used in this study

[Aquifer codes: $s$, surficial aquifer; u, Upper Floridan aquifer; m. middle semiconfining unit; l, Lower Floridan aquifer; um, Upper Floridan aquifer and middle semiconfining unit; uml, Upper Floridan Aquifer, middle semiconfining unit, and Lower Floridan aquifer. Source of data: B, Barraclough (1961); J, Jammal \& Associates (1990); LCES, Lake County Environmental Services; PBS\&J, Post, Buckley, Schuh, and Jernigan (1989); S, Stringfield, (1936); SJRWMD, St. Johns River Water Management District; U, Unklesbay (1944); USEO, U.S. Engineers Office (1946); USGS, U.S. Geological Survey; YES, Yovaish Engineering Sciences (1994). ---, no data. Well depths and cased depths are referenced to land-surface datum]

\begin{tabular}{|c|c|c|c|c|c|c|c|}
\hline $\begin{array}{l}\text { Model } \\
\text { row }\end{array}$ & $\begin{array}{l}\text { Model } \\
\text { column }\end{array}$ & $\begin{array}{l}\text { Identification } \\
\text { number }\end{array}$ & $\begin{array}{l}\text { Local name and/or other well } \\
\text { identification number }\end{array}$ & $\begin{array}{l}\text { Total } \\
\text { depth } \\
\text { (feet) }\end{array}$ & $\begin{array}{l}\text { Cased } \\
\text { depth } \\
\text { (feet) }\end{array}$ & $\begin{array}{l}\text { Aquifer } \\
\text { code }\end{array}$ & $\begin{array}{l}\text { Source } \\
\text { of data }\end{array}$ \\
\hline 40 & 6 & 281511081393101 & 815-139-342 USGS well & 447 & 358 & $\mathrm{u}$ & USGS \\
\hline 40 & 11 & 281532081345001 & Loughman deep well & 247 & 85 & $\mathrm{u}$ & USGS \\
\hline 40 & 19 & 281559081260701 & Shingle Creek well at SR 531A & 200 & --- & $\mathrm{u}$ & USGS \\
\hline 39 & 43 & 281630081024401 & TH-9 Nova Rd 532 West & 405 & 228 & $\mathrm{u}$ & USGS \\
\hline 39 & 46 & 281630080591001 & TH-3 Lake Poinsett SW & 377 & 245 & $\mathrm{u}$ & USGS \\
\hline 39 & 54 & 281632080515001 & DSR-38 Lake Poinsett & 253 & -- & $\mathrm{u}$ & USGS \\
\hline 38 & 51 & 281722080543001 & OS-171 shallow well nr Deer Park & 19 & 13 & $\mathrm{~s}$ & USGS \\
\hline 38 & 32 & 281719081134001 & South Eagle Road E. Narcoossee & 480 & 245 & $\mathbf{u}$ & USGS \\
\hline 38 & 36 & 281714081093001 & ${ }^{1}$ Lake Joel well & 750 & 394 & $\mathrm{u}$ & USGS \\
\hline 38 & 20 & Well \#3 & & --- & --- & $\mathbf{u}$ & $\mathrm{U}$ \\
\hline 37 & 51 & 281820080540501 & K6-Tilt Lake Poinsett SW & 603 & 108 & $\mathbf{u}$ & USGS \\
\hline 36 & 17 & 281931081280301 & KOA Campground well nr Kissimmee & 378 & --- & $\mathbf{u}$ & USGS \\
\hline 36 & 21 & 281937081245901 & 819-124-01 Kissimmee well & 1,200 & 280 & uml & USGS \\
\hline 35 & 27 & 282051081183401 & USGS well at Boggy Creek Road & 400 & 199 & $\mathrm{u}$ & USGS \\
\hline 34 & 5 & 282126081403901 & Lake County well $821-140-01$ & --- &.- & $\mathbf{u}$ & USGS \\
\hline 34 & 9 & 282145081365601 & Britt Groves trailer park & --- & --- & $\mathbf{u}$ & USGS \\
\hline 34 & 21 & 282141081241701 & USGS well-US441 at phone relay & 435 & 317 & $\mathbf{u}$ & USGS \\
\hline 33 & 1 & 2822410814439 & SJRWMD L-0050 Sand mine shallow & 35 & 25 & $\mathrm{~s}$ & SJRWMD \\
\hline 33 & 7 & 282202081384601 & ${ }^{1}$ Lake Oliver deep well & 318 & 103 & u & USGS \\
\hline 33 & 7 & 282202081384602 & Lake Oliver shallow well & 38 & --- & $\mathrm{s}$ & USGS \\
\hline 33 & 21 & Orange 63 & & 300 & $-\ldots$ & $\mathbf{u}$ & $\mathrm{S}$ \\
\hline 33 & 23 & Orange 64 & & 300 & --- & $\mathrm{u}$ & $\mathrm{S}$ \\
\hline 33 & 34 & 282241081112801 & USGS well at Moss Park & 460 & 240 & $\mathrm{u}$ & USGS \\
\hline 33 & 34 & 282241081112802 & USGS shallow well at Moss Park & -.. & -- & $\mathrm{s}$ & USGS \\
\hline 33 & 54 & 282204080514301 & USGS 822-051-001 SR520 & 553 & --- & $\mathbf{u}$ & USGS \\
\hline 33 & 10 & 282210081352601 & Disney shallow well at Tree Farm & 18 & 18 & $\mathrm{~s}$ & USGS \\
\hline 32 & 8 & 282331081370801 & USGS well at Hartzog Road & 166 & 68 & $\mathrm{u}$ & USGS \\
\hline 32 & 14 & 282354081313001 & RCID observation well \# 1 & 281 & 145 & $\mathrm{u}$ & USGS \\
\hline 32 & 40 & 282344081054201 & Cocoa \# 11 & 580 & 323 & $\mathrm{u}$ & USGS \\
\hline 32 & 41 & 282341081040101 & ${ }^{1}$ Cocoa A & 516 & 301 & $\mathrm{u}$ & USGS \\
\hline 32 & 49 & 282348080564701 & 82305601 24S34E18 442 Palmetto & 390 & 244 & $\mathrm{u}$ & USGS \\
\hline 31 & 16 & Orange 62 & & 484 & -- & $\mathrm{u}$ & $\mathrm{S}$ \\
\hline 31 & 17 & 282434081283101 & ${ }^{1}$ USGS well at I-4 and Sea World Dr & 235 & 158 & $\mathrm{u}$ & USGS \\
\hline 31 & 19 & 282434081260301 & USGS well at Shingle Creek & 203 & 131 & $\mathrm{u}$ & USGS \\
\hline 31 & 40 & 282416081054101 & Cocoa \#4 & 524 & 252 & $\mathrm{u}$ & USGS \\
\hline 30 & 7 & 282543081385801 & 82513801; Hickory Nut Lake well & --- & --- & $\mathrm{u}$ & USGS \\
\hline 30 & 11 & 282528081340901 & ${ }^{1}$ Bay Lake deep well & 223 & 104 & $\mathrm{u}$ & USGS \\
\hline 30 & 15 & 282556081302404 & Dr. Phillips deep well & 230 & 50 & $\mathrm{u}$ & USGS \\
\hline 30 & 21 & 282545081240901 & 825-124-01; Turnpike Orlando South 30 & 450 & 212 & $\mathrm{u}$ & USGS \\
\hline 30 & 36 & 282530081094001 & Cocoa \#17 & 600 & 252 & $\mathrm{u}$ & USGS \\
\hline 30 & 37 & 282531081082201 & Cocoa \#14 & 761 & 252 & u & USGS \\
\hline 30 & 38 & 282529081073201 & Cocoa \#7A & 710 & 237 & $\mathrm{u}$ & USGS \\
\hline 30 & 40 & 282548081054201 & Cocoa \# 3 & 496 & 266 & $\mathrm{u}$ & USGS \\
\hline 30 & 40 & 282530081054201 & Cocoa \#7 & 490 & 285 & $\mathrm{u}$ & USGS \\
\hline 30 & 40 & 282510081054502 & Cocoa-M nr Bithlo & 10 & 10 & $\mathrm{~s}$ & USGS \\
\hline 30 & 40 & 282510081054501 & Cocoa 1 nr Bithlo & 710 & 316 & $\mathrm{u}$ & USGS \\
\hline 30 & 37 & 282533081082202 & Cocoa $\mathrm{C}$ (zone 1 ) monitor well & 1,357 & 1,351 & 1 & USGS \\
\hline 30 & 37 & 28253308108220 & Cocoa $\mathrm{C}$ (zone 5 ) aquifer well & 1,004 & 248 & $\mathrm{u}$ & USGS \\
\hline 29 & 3 & 282633081425601 & Bradshaw Windmill & --- & --- & $\mathrm{u}$ & USGS \\
\hline
\end{tabular}


Appendix A. Index to wells used in this study--Continued

[Aquifer codes: s, surficial aquifer; u, Upper Floridan aquifer; m, middle semiconfining unit; 1, Lower Floridan aquifer; um, Upper Floridan aquifer and middle semiconfining unit; uml, Upper Floridan Aquifer, middle semiconfining unit, and Lower Floridan aquifer. Source of data: B, Barraclough (1961); J, Jammal \& Associates (1990); LCES, Lake County Environmental Services; PBS\&J, Post, Buckley, Schuh, and Jernigan (1989); S, Stringfield, (1936); SJRWMD, St. Johns River Water Management District; U, Unklesbay (1944); USEO, U.S. Engineers Office (1946); USGS, U.S. Geological Survey;

YES, Yovaish Engineering Sciences (1994), ---, no data. Well depths and cased depths are referenced to land-surface datum]

\begin{tabular}{|c|c|c|c|c|c|c|c|}
\hline $\begin{array}{l}\text { Model } \\
\text { row }\end{array}$ & $\begin{array}{l}\text { Model } \\
\text { column }\end{array}$ & $\begin{array}{l}\text { Identification } \\
\text { number }\end{array}$ & $\begin{array}{l}\text { Local name and/or other well } \\
\text { identification number }\end{array}$ & $\begin{array}{l}\text { Total } \\
\text { depth } \\
\text { (feet) }\end{array}$ & $\begin{array}{l}\text { Cased } \\
\text { depth } \\
\text { (feet) }\end{array}$ & $\begin{array}{l}\text { Aquifer } \\
\text { code }\end{array}$ & $\begin{array}{l}\text { Source } \\
\text { of data }\end{array}$ \\
\hline 29 & 13 & 282611081320501 & 82613201; USGS well on Sunset Dr & 180 & 95 & $\mathrm{u}$ & USGS \\
\hline 29 & 30 & 282623081153801 & ${ }^{1}$ Cocoa P & 439 & 245 & $\mathrm{u}$ & USGS \\
\hline 29 & 40 & 283632081054501 & Cocoa \# 8 & 640 & 255 & $\mathrm{u}$ & USGS \\
\hline 29 & 40 & 282650081054201 & Cocoa \#9 & 525 & 230 & $\mathrm{u}$ & USGS \\
\hline 28 & 17 & 282709081283001 & USGS well nr I-4 and SR528A & 205 & 68 & $\mathrm{u}$ & USGS \\
\hline 28 & 1 & 282729081443301 & Lake Louisa State Park well & 85 & --- & $\mathrm{u}$ & USGS \\
\hline 28 & 11 & 282738081341401 & USGS well at Lake Sawyer & 178 & 103 & $\mathrm{u}$ & USGS \\
\hline 28 & 14 & 282749081315801 & 82713101LK; Butler Groves supply & 347 & 120 & $\mathrm{u}$ & USGS \\
\hline 28 & 22 & Orange 37 & & 375 & 272 & $\mathrm{u}$ & S \\
\hline 28 & 40 & 282739081054501 & Cocoa F & 375 & 200 & $\mathrm{u}$ & USGS \\
\hline 28 & 40 & 282716081054501 & Cocoa \#10 & 506 & 229 & $\mathrm{u}$ & USGS \\
\hline 27 & 16 & 282835081305201 & USGS well Palm Lake Dr & 235 & 161 & $\mathrm{u}$ & USGS \\
\hline 27 & 44 & 282847081013701 & Cocoa-H nr Bithlo & 495 & 252 & $\mathrm{u}$ & USGS \\
\hline 27 & 44 & 282847081013702 & Cocoa-K nr Bithlo & 8 & 8 & $\mathrm{~s}$ & USGS \\
\hline 27 & 48 & 282838080572401 & Turkey Camp & --- & --- & u & USGS \\
\hline 27 & 51 & 282848080544501 & Tosohatchee Game Preserve & 335 & 152 & $\mathrm{u}$ & USGS \\
\hline 11 & 280 & 282936081340201 & 32913405; Ross home well Lk Butler 26 & 180 & u & & USGS \\
\hline 26 & 17 & 282923081282801 & Iveys Nursery at Turkey Lake Rd & 337 & 168 & $\mathrm{u}$ & USGS \\
\hline 26 & 20 & 282945081255001 & $829-125-01 ;$ Orange 39 on I-4 & 168 & --- & $\mathrm{u}$ & USGS \\
\hline 26 & 21 & 282911081243601 & Americana Apts at Texas Ave & --- & --- & $\mathrm{u}$ & USGS \\
\hline 26 & 30 & & Orange Cnty eastern regional LFEW & & & & $\mathbf{J}$ \\
\hline 25 & 6 & 283017081391301 & Davenport Road 4-inch well & $-\ldots$ & --- & $\mathrm{u}$ & USGS \\
\hline 25 & 9 & 283011081360002 & West Orange Country Club well & 260 & 100 & $\mathrm{u}$ & USGS \\
\hline 25 & 20 & Orange 44 & & 463 & 105 & $\mathrm{u}$ & $S$ \\
\hline 25 & 26 & 283017081195201 & 83011901; Lk Margaret \& Conway Rd & 427 & 169 & $\mathrm{u}$ & USGS \\
\hline 25 & 27 & Orange 46 & & 422 & 137 & $\mathrm{u}$ & $S$ \\
\hline 24 & 1 & 283116081442301 & 76 Pot Map well & --- & --- & $\mathrm{u}$ & USGS \\
\hline 24 & 5 & 283128081404701 & Johns Lake well nr Clermont & 155 & -- & $\mathrm{u}$ & USGS \\
\hline 24 & 14 & 283121081311601 & O-197 Lake Olivia drain well & 498 & 344 & $\mathrm{u}$ & USGS \\
\hline 24 & 20 & 283144081254201 & 831-125-04; Lake Mann drain well & 400 & 137 & $\mathrm{u}$ & USGS \\
\hline 24 & 22 & 283135081234301 & 831-123-19; Layne-Atlantic deep & 460 & 145 & $\mathrm{u}$ & USGS \\
\hline 24 & 23 & 283105081222201 & 831-122-03; Delaney \& Harding Str & 438 & 153 & $\mathrm{u}$ & USGS \\
\hline 24 & 24 & Orange 52 & & 435 & 113 & $\mathrm{u}$ & $S$ \\
\hline 23 & 17 & 283253081283401 & ${ }^{1} \mathrm{OR}-47$ well at Orlo Vista & 350 & 328 & $\mathrm{u}$ & USGS \\
\hline 23 & 17 & 283253081283404 & OR $-47 \mathrm{~B}$ replacement well at Orlo & 35 & 33 & $\mathrm{~s}$ & USGS \\
\hline 23 & 25 & 283219081195701 & Lake Underhill drain well & 399 & 270 & $\mathrm{u}$ & USGS \\
\hline 23 & 28 & Well \#242 & & -- & -- & $\mathrm{u}$ & $\mathrm{U}$ \\
\hline 23 & 40 & 283249081053201 & ${ }^{1}$ Bithlo-1 at Bithlo & 492 & 151 & $\mathrm{u}$ & USGS \\
\hline 23 & 40 & 283249081053203 & Bithlo-3 at Bithlo & 15 & 12 & $\mathrm{~s}$ & USGS \\
\hline 23 & 46 & Orange 66 & & 200 & -- & $\mathrm{u}$ & S \\
\hline 23 & 47 & 283214080583501 & 83205801; DOT East HWY50 & 200 & $-\cdots$ & $\mathrm{u}$ & USGS \\
\hline 23 & 52 & 283236080535101 & Old SR50 well & 247 & -- & $\mathrm{u}$ & USGS \\
\hline 22 & 2 & 283307081435301 & 76 Pot Map; Jacks Lake well & --- & -- & $\mathrm{u}$ & USGS \\
\hline 22 & 4 & 2833530814117 & SJRWMD L-0044 & --- & --- & $\mathrm{s}$ & SJRWMD \\
\hline 22 & 4 & 283359081411501 & 833-141-01; Well FDAWPC & 132 & 107 & $\mathrm{u}$ & USGS \\
\hline 22 & 5 & 2833330814028 & SJRWMD L-0276 & 45 & 40 & $\mathrm{~s}$ & SJRWMD \\
\hline 22 & 8 & 2833490813715 & SJRWMD OR0085 & --- & --- & s & SJRWMD \\
\hline 22 & 8 & 283325081374001 & 833-137-03; City of Oakland \#2 & 370 & 148 & $\mathrm{u}$ & USGS \\
\hline 22 & 12 & Orange 61 & & 500 & -- & $\mathrm{u}$ & $\mathrm{S}$ \\
\hline 22 & 15 & 283307081300801 & 833-130-01; Lk Sherwood drain well 22 & 450 & 118 & $\mathrm{u}$ & USGS \\
\hline
\end{tabular}


Appendix A. Index to wells used in this study--Continued

[Aquifer codes: s, surficial aquifer; u, Upper Floridan aquifer; m, middle semiconfining unit; 1, Lower Floridan aquifer; um, Upper Floridan aquifer and middle semiconfining unit; uml, Upper Floridan Aquifer, middle semiconfining unit, and Lower Floridan aquifer. Source of data: B, Barraclough (1961); J, Jammal \& Associates (1990); LCES, Lake County Environmental Services; PBS\&J, Post, Buckley, Schuh, and Jernigan (1989); S, Stringfield, (1936); SJRWMD, St. Johns River Water Management District; U, Unklesbay (1944); USEO, U.S. Engineers Office (1946); USGS, U.S. Geological Survey; YES, Yovaish Engineering Sciences (1994). ---, no data. Well depths and cased depths are referenced to land-surface datum]

\begin{tabular}{|c|c|c|c|c|c|c|c|}
\hline $\begin{array}{l}\text { Model } \\
\text { row }\end{array}$ & $\begin{array}{l}\text { Model } \\
\text { column }\end{array}$ & $\begin{array}{l}\text { Identification } \\
\text { number }\end{array}$ & $\begin{array}{l}\text { Local name and/or other well } \\
\text { identification number }\end{array}$ & $\begin{array}{l}\text { Total } \\
\text { depth } \\
\text { (feet) }\end{array}$ & $\begin{array}{l}\text { Cased } \\
\text { depth } \\
\text { (feet) }\end{array}$ & $\begin{array}{l}\text { Aquifer } \\
\text { code }\end{array}$ & $\begin{array}{l}\text { Source } \\
\text { of data }\end{array}$ \\
\hline 22 & 19 & 283326081262101 & 833-126-02; Lake Lawne drain well & 109 & 84 & $\mathrm{u}$ & USGS \\
\hline 22 & 20 & Orange 48 & & 123 & 75 & $\mathrm{u}$ & $\mathrm{S}$ \\
\hline 22 & 22 & 283333081233501 & Lake Adair deep well & 1,281 & 601 & $\mathrm{ml}$ & USGS \\
\hline 22 & 22 & 283333081233502 & ${ }^{1}$ Lake Adair shallow well & 400 & 105 & $\mathrm{u}$ & USGS \\
\hline 22 & 39 & Orange 65 & & 211 & 205 & $\mathrm{u}$ & $\mathrm{S}$ \\
\hline 21 & 20 & Orange 51 & & 199 & 100 & $\mathrm{u}$ & $\mathrm{S}$ \\
\hline 21 & 26 & 283436081194501 & Lake Speir drain well & --- & --- & $\mathrm{u}$ & USGS \\
\hline 20 & 5 & 283540081402401 & 77 Pot Map & 180 & --- & $\mathrm{u}$ & USGS \\
\hline 20 & 11 & 283524081344701 & 835-134-01; Lake Apopka test well & 202 & 133 & $\mathbf{u}$ & USGS \\
\hline 20 & 22 & 283528081235201 & 835-123-02; Lk Fairview drain well 20 & 745 & 176 & um & USGS \\
\hline 20 & 23 & 283548081224601 & Lake Killarney drain well & 400 & 200 & $\mathrm{u}$ & USGS \\
\hline 20 & 24 & 283530081214301 & 835-121-07; Lk Midget drain well & 372 & 170 & $\mathrm{u}$ & USGS \\
\hline 19 & 54 & 283627080512001 & Champion Rd well at Titusville & 136 & 132 & $\mathrm{u}$ & USGS \\
\hline 19 & 12 & Orange 57 & & 465 & - & u & $\mathrm{S}$ \\
\hline 19 & 17 & 283655081283401 & Long Lake drain well & 301 & 144 & $\mathrm{u}$ & USGS \\
\hline 19 & 19 & 283654081260801 & 836-126-04; Lk Davis drain well & 365 & 250 & $\mathrm{u}$ & USGS \\
\hline 19 & 48 & 283644080574901 & Silver Lake Hatbill Park well & 247 & --- & $\mathrm{u}$ & USGS \\
\hline 18 & 16 & & Orange Cnty western regional WF TP-2 & 1,455 & 1,040 & & PBS\&J \\
\hline 18 & 26 & 283717081194202 & 837-119-04; W C Phillips well & 290 & 85 & $\mathrm{u}$ & USGS \\
\hline 18 & 30 & 283754081154301 & $837-115-02 ; \mathrm{R} O$ Woods well & 131 & -- & $\mathrm{u}$ & USGS \\
\hline 18 & 55 & 2837320805059 & SJRWMD BR0584 Astronaut High & 40 & 32 & s & SJRWMD \\
\hline 18 & 42 & 283740081031401 & C S Lee well \#879 nr pumphouse & 273 & 84 & $\mathrm{u}$ & USGS \\
\hline 17 & 12 & 2838020813301 & SJRWMD OR0086 & 27 & 25 & s & SJRWMD \\
\hline 17 & 13 & 283813081325701 & $83813204 ;$ State Foliage Research & 1,200 & --- & -- & USGS \\
\hline 17 & 18 & 283849081273401 & 838-127-02; Ecolog Utility well & 105 & --- & $\mathbf{u}$ & USGS \\
\hline 17 & 23 & 283816081225501 & Lake Charity well nr Maitland & 374 & 325 & $\mathbf{u}$ & USGS \\
\hline 17 & 32 & Seminole 14 & & 126 & --- & $\mathrm{u}$ & $\mathrm{S}$ \\
\hline 17 & 38 & 283843081075501 & 838-107-06; W H Green well & 107 & 95 & $\mathrm{u}$ & USGS \\
\hline 16 & 25 & 283958081203401 & $840-120-02$ & 101 & --- & $\mathrm{u}$ & USGS \\
\hline 16 & 32 & $839-113-01$ & & 200 & 100 & $\mathrm{u}$ & B \\
\hline 16 & 34 & --- & City of Oviedo LFTW & 1,290 & 1,230 & & YES \\
\hline 16 & 38 & 283945081071901 & 83910702 21S32E16 411 C Brown & 190 & --- & $\mathrm{u}$ & USGS \\
\hline 16 & 41 & 283956081040201 & 839-104-02; Yardborough well & 71 & --- & $\mathrm{u}$ & USGS \\
\hline 16 & 49 & 283955080565701 & PB Plastic well & 97 & --- & $\mathrm{u}$ & USGS \\
\hline 16 & 54 & 283906080514501 & Parrish \& Holder Rds Titusville & 137 & $\ldots$ & $\mathrm{u}$ & USGS \\
\hline 15 & 15 & 284025081301701 & 84013002; Apopka drain well & 423 & 124 & $\mathrm{u}$ & USGS \\
\hline 15 & 19 & 284012081264601 & 840-126-03; C Benton Inc well & -- & -- & $\mathrm{u}$ & USGS \\
\hline 15 & 21 & 284023081241001 & 840-124-04; USGS well & 140 & --- & $\mathrm{u}$ & USGS \\
\hline 15 & 33 & 284025081123001 & $8401120121 \mathrm{~S} 31 \mathrm{E} 10313$ & 282 & 85 & $\mathrm{u}$ & USGS \\
\hline 15 & 33 & Seminole 4 & & 225 & 80 & $\mathrm{u}$ & $\mathrm{S}$ \\
\hline 15 & 35 & Seminole 12 & & 125 & 80 & $\mathrm{u}$ & $\mathrm{S}$ \\
\hline 15 & 37 & $840-108-01$ & & 105 & 70 & $\mathrm{u}$ & B \\
\hline 14 & 4 & 284129081414201 & 77 Pot Map & 69 & --- & $\mathrm{u}$ & USGS \\
\hline 14 & 23 & 284147081220201 & ${ }^{1}$ Seminole 125 at Longwood & 158 & 63 & $\mathrm{u}$ & USGS \\
\hline 14 & 30 & 284120081152201 & 841-115-01; Ed Bouillon well & 185 & -- & $\mathrm{u}$ & USGS \\
\hline 14 & 32 & 284125081131701 & 841-113-01; Curtis Mann well & 90 & 80 & $\mathrm{u}$ & USGS \\
\hline 14 & 32 & Seminole 10 & & 100 & --- & $\mathrm{u}$ & $\mathrm{S}$ \\
\hline 14 & 33 & Seminole 5 & & 100 & --- & $\mathrm{u}$ & $\mathrm{S}$ \\
\hline 14 & 34 & $841-111-01$ & & -- & -- & $\mathrm{u}$ & B \\
\hline 14 & 36 & Seminole 11 & & 103 & --- & $\mathrm{u}$ & $\mathrm{S}$ \\
\hline
\end{tabular}


Appendix A. Index to wells used in this study--Continued

[Aquifer codes: s, surficial aquifer; u, Upper Floridan aquifer; m, middle semiconfining unit; 1, Lower Floridan aquifer; um, Upper Floridan aquifer and middle semiconfining unit; uml, Upper Floridan Aquifer, middle semiconfining unit, and Lower Floridan aquifer. Source of data: B, Barraclough (1961); J, Jammal \& Associates (1990); LCES, Lake County Environmental Services; PBS\&J, Post, Buckley, Schuh, and Jernigan (1989); S, Stringfield, (1936); SJRWMD, St. Johns River Water Management District; U, Unklesbay (1944); USEO, U.S. Engineers Office (1946); USGS, U.S. Geological Survey; YES, Yovaish Engineering Sciences (1994). ---, no data. Well depths and cased depths are referenced to land-surface datum]

\begin{tabular}{|c|c|c|c|c|c|c|c|}
\hline $\begin{array}{l}\text { Model } \\
\text { row }\end{array}$ & $\begin{array}{l}\text { Model } \\
\text { column }\end{array}$ & $\begin{array}{l}\text { Identification } \\
\text { number }\end{array}$ & $\begin{array}{l}\text { Local name and/or other well } \\
\text { identification number }\end{array}$ & $\begin{array}{l}\text { Total } \\
\text { depth } \\
\text { (feet) }\end{array}$ & $\begin{array}{l}\text { Cased } \\
\text { depth } \\
\text { (feet) }\end{array}$ & $\begin{array}{l}\text { Aquifer } \\
\text { code }\end{array}$ & $\begin{array}{l}\text { Source } \\
\text { of data }\end{array}$ \\
\hline 13 & 18 & 284234081273901 & 84212702; Wekiva State Park well & --- & -- & $\mathbf{u}$ & USGS \\
\hline 13 & 22 & 284244081234901 & 842-123-02; Quartel well & 118 & -- & $\mathrm{u}$ & USGS \\
\hline 13 & 28 & 284207081174401 & 842-117-03; Neely well & 90 & --- & $\mathrm{u}$ & USGS \\
\hline 13 & 33 & Seminole 6 & & 100 & 70 & $\mathrm{u}$ & $\mathrm{S}$ \\
\hline 13 & 38 & 284247081070801 & ${ }^{1}$ Geneva S-0001 & 204 & 95 & $\mathrm{u}$ & USGS \\
\hline 13 & 38 & 284247081070802 & Geneva S-0002 & 50 & 45 & s & USGS \\
\hline 13 & 43 & 284217081023001 & Kilbee \#3 test well nr Geneva & 154 & 58 & $\mathrm{u}$ & USGS \\
\hline 12 & 9 & 284330081360501 & 84313603; Jewell Foliage well & 403 & 127 & $\mathrm{u}$ & USGS \\
\hline 12 & 17 & 284326081283601 & Mill Creek cabin & 200 & -- & $u$ & USGS \\
\hline 12 & 24 & 284317081213401 & Gilbert Principe & --- & --- & $\mathrm{u}$ & USGS \\
\hline 12 & 26 & Seminole 1 & & 100 & --- & $\mathrm{u}$ & S \\
\hline 12 & 27 & $843-118-02$ & & 104 & 80 & $\mathrm{u}$ & B \\
\hline 12 & 36 & 284325081092702 & Cochran Forest shallow well & 37 & --- & s & USGS \\
\hline 12 & 42 & 284331081031001 & 84310302 20S33E30 241 Pecor & 117 & --- & $\mathrm{u}$ & USGS \\
\hline 11 & 9 & 284453081365101 & Sadler Road nr Lake Ola & 325 & -- & $\mathrm{u}$ & USGS \\
\hline 11 & 17 & 284453081284401 & 84412801; Wekiva Park fireplace & $40(?)$ & -- & $\mathrm{u}$ & USGS \\
\hline 11 & 28 & 284440081175901 & 844-117-22; Seminole County well & 250 & 75 & $\mathrm{u}$ & USGS \\
\hline 11 & 28 & $844-117-02$ & & 67 & 61 & $\mathrm{u}$ & B \\
\hline 11 & 29 & $844-116-01$ & & 150 & 88 & $\mathrm{u}$ & B \\
\hline 11 & 30 & 284428081155201 & Largent well Sanford Ave. & --- & --- & $\mathrm{u}$ & USGS \\
\hline 11 & 30 & $844-115-08$ & & 122 & 91 & $\mathrm{u}$ & $\mathrm{B}$ \\
\hline 11 & 31 & $844-114-01$ & & 150 & 100 & $\mathrm{u}$ & B \\
\hline 11 & 38 & 284428081072602 & USGS Avenue C deep zone at Geneva & 393 & 388 & $\mathrm{u}$ & USGS \\
\hline 11 & 40 & 284434081050101 & 844-105-03; Lake Harney well & 60 & --- & $\mathrm{u}$ & USGS \\
\hline 10 & 1 & Astatula $3 \mathrm{~A}$ & & --- & -- & s & LCES \\
\hline 10 & 15 & 284529081301001 & 84513001; Rock Springs deep well & 365 & 143 & $\mathrm{u}$ & USGS \\
\hline 10 & 25 & 284533081204801 & $845-120-05 ;$ The Forest well & 471 & 97 & $\mathrm{u}$ & USGS \\
\hline 10 & 27 & $845-118-01$ & & 135 & 96 & u & B \\
\hline 10 & 32 & $845-113-01$ & & 145 & 100 & $\mathrm{u}$ & B \\
\hline 10 & 38 & 284550081071501 & 845-107-03; Cameron Brothers well & 126 & 77 & $\mathrm{u}$ & USGS \\
\hline 9 & 26 & 284651081193301 & 846-119-02; Southward Fort well & 69 & --- & $\mathrm{u}$ & USGS \\
\hline 9 & 29 & $846-116-11$ & & 104 & -- & $\mathrm{u}$ & B \\
\hline 9 & 30 & 284645081152401 & 846-115-15; U S Navy well & 185 & 108 & $\mathrm{u}$ & USGS \\
\hline 9 & 36 & 284618081095401 & 846-109-02; W H Wight well & 63 & -- & $\mathrm{u}$ & USGS \\
\hline 9 & 40 & 284626081051801 & Osceola Road test well nr Geneva & 200 & 83 & $\mathrm{u}$ & USGS \\
\hline 8 & 13 & 284728081322201 & Central Florida Academy well & 400 & 63 & $\mathrm{u}$ & USGS \\
\hline 8 & 32 & 284750081132301 & Seminole $257 \mathrm{nr}$ Sanford & 206 & --- & $\mathrm{u}$ & USGS \\
\hline 8 & 33 & Well\#478 & & --- & --- & $\mathrm{u}$ & USEO \\
\hline 8 & 38 & 284706081070801 & 847-107-03; S C Thrasher well & 178 & 99 & $\mathrm{u}$ & USGS \\
\hline 8 & 40 & 2847150810518 & SJRWMD S-0201 & 25 & 15 & $\mathrm{~s}$ & SJRWMD \\
\hline 8 & 41 & 284712081044301 & 847-104-01; Seminole County well & 141 & 70 & $\mathrm{u}$ & USGS \\
\hline 8 & 53 & 284743080520101 & W L Cantrell well & 197 & -- & $\mathrm{u}$ & USGS \\
\hline 7 & 2 & Lake 8 & & 185 & --- & $\mathrm{u}$ & $\mathrm{S}$ \\
\hline 7 & 2 & 284808081432801 & Tavares well & 417 & 226 & $\mathrm{u}$ & USGS \\
\hline 7 & 5 & 284827081403501 & 848-140-01; D Bartholow well & 271 & 192 & $\mathrm{u}$ & USGS \\
\hline 7 & 20 & 284826081254601 & $848-125-02 ;$ S Hardin well & 400 & 200 & $\mathrm{u}$ & USGS \\
\hline 7 & 21 & 284802081242101 & Via Hermosa well & -- & -- & $\mathrm{u}$ & USGS \\
\hline 7 & 24 & 284802081211101 & Hartstock Wilson Ave. well & 147 & 81 & $\mathrm{u}$ & USGS \\
\hline 7 & 26 & 284802081192701 & Jordan Baptist well Upsala Rd & 120 & 70 & $\mathrm{u}$ & USGS \\
\hline 7 & 26 & $848-119-04$ & & 168 & 90 & $\mathrm{u}$ & B \\
\hline
\end{tabular}


Appendix A. Index to wells used in this study--Continued

[Aquifer codes: s, surficial aquifer; u, Upper Floridan aquifer; m, middle semiconfining unit; l, Lower Floridan aquifer; um, Upper Floridan aquifer and middle semiconfining unit; uml, Upper Floridan Aquifer, middle semiconfining unit, and Lower Floridan aquifer. Source of data: B, Barraclough (1961); J, Jammal \& Associates (1990); LCES, Lake County Environmental Services; PBS\&J, Post, Buckley, Schuh, and Jernigan (1989); S, Stringfield, (1936); SJRWMD, St. Johns River Water Management District; U, Unklesbay (1944); USEO, U.S. Engineers Office (1946); USGS, U.S. Geological Survey; YES, Yovaish Engineering Sciences (1994). ---, no data. Well depths and cased depths are referenced to land-surface datum]

\begin{tabular}{|c|c|c|c|c|c|c|c|}
\hline $\begin{array}{l}\text { Model } \\
\text { row }\end{array}$ & $\begin{array}{l}\text { Model } \\
\text { column }\end{array}$ & $\begin{array}{l}\text { Identification } \\
\text { number }\end{array}$ & $\begin{array}{l}\text { Local name and/or other well } \\
\text { identification number }\end{array}$ & $\begin{array}{l}\text { Total } \\
\text { depth } \\
\text { (feet) }\end{array}$ & $\begin{array}{l}\text { Cased } \\
\text { depth } \\
\text { (feet) }\end{array}$ & $\begin{array}{l}\text { Aquifer } \\
\text { code }\end{array}$ & $\begin{array}{l}\text { Source } \\
\text { of data }\end{array}$ \\
\hline 7 & 29 & $848-116-02$ & & 150 & 125 & $\mathrm{u}$ & B \\
\hline 7 & 30 & Seminole 24 & & 100 & --- & $\mathrm{u}$ & $S$ \\
\hline 6 & 10 & 284917081353701 & 849-135-01; Rickey \& Reed well & --- & --- & $\mathrm{u}$ & USGS \\
\hline 6 & 21 & 284945081244201 & 849-124-07; C Fernandez well & 41 & --- & $\mathrm{u}$ & USGS \\
\hline 6 & 25 & 284954081201101 & Anderson well Missouri Street & 228 & 128 & $\mathrm{u}$ & USGS \\
\hline 6 & 26 & $849-119-03$ & & 120 & 100 & $\mathrm{u}$ & B \\
\hline 6 & 27 & $849-118-05$ & & 200 & 144 & $\mathrm{u}$ & B \\
\hline 6 & 34 & 284902081112001 & 849-111-01; B R Beck well & --- & --- & $\mathrm{u}$ & USGS \\
\hline 5 & 24 & 285002081215101 & Cain well & $\cdots$ & --- & $\mathrm{u}$ & USGS \\
\hline 5 & 26 & 285040081192101 & Stewart well S of DeBary & 143 & 140 & $\mathrm{u}$ & USGS \\
\hline 5 & 36 & 285044081094901 & Osteen convenience store well & 220 & --- & $\mathrm{u}$ & USGS \\
\hline 5 & 39 & 285045081063501 & 850-106-03; Turner Farms well & 280 & --- & $\mathrm{u}$ & USGS \\
\hline 5 & 39 & 2850310810623 & SJRWMD V-0166 Winston Took farm & 35 & 25 & $\mathrm{~s}$ & SJRWMD \\
\hline 5 & 54 & 285016081014101 & 850101; Cow Creek well nr Maytown & 107 & 102 & $\mathrm{u}$ & USGS \\
\hline 4 & 5 & Lake 10 & & 180 & --- & $\mathrm{u}$ & $S$ \\
\hline 4 & 26 & 285156081190302 & 851-119-02; Florida Power well & --- & --- & $\mathrm{u}$ & USGS \\
\hline 4 & 53 & 285143080521401 & Loomis Nursery W of Oak Hill & 120 & --- & $\mathrm{u}$ & USGS \\
\hline 3 & 2 & 285257081434201 & J. Eichelburger well & 297 & 108 & $\mathrm{u}$ & USGS \\
\hline 3 & 36 & 285221081095002 & 852-109-01; USGS well & 92 & 74 & $\mathrm{u}$ & USGS \\
\hline 2 & 11 & 285318081340601 & Sand mine well & 350 & -- & $\mathrm{u}$ & USGS \\
\hline 2 & 29 & 285359081161701 & Deltona Corp Diamond St Deltona & 250 & 76 & $\mathrm{u}$ & USGS \\
\hline 1 & 7 & 285426081380901 & A B Marshall well & 125 & $\ldots$ & $\mathrm{u}$ & USGS \\
\hline 1 & 27 & 2854420811814 & SJRWMD V-0197 Orange City tower & 30 & 20 & s & SJRWMD \\
\hline 1 & 27 & 285437081181401 & SJRWMD test well nr Orange City & 230 & --- & $\mathrm{u}$ & USGS \\
\hline 1 & 41 & 2854190810410 & SJRWMD V-0199 Lake Ashby shallow & 86 & 86 & $\mathrm{u}$ & SJRWMD \\
\hline 1 & 50 & 285452080551801 & N. of Volco Road near Ariel & 148 & --- & $\mathrm{u}$ & USGS \\
\hline
\end{tabular}

${ }^{1}$ Well with continuous hydrograph record. 
Appendix B. Names and locations of lakes and streams used in this study

[USGS, U.S. Geological Survey; SEMCO, Seminole County; OCPUD, Orange County Public Utilities Department; do., same; ---, no data]

\begin{tabular}{|c|c|c|c|c|}
\hline $\begin{array}{c}\text { Model } \\
\text { row }\end{array}$ & $\begin{array}{l}\text { Model } \\
\text { column }\end{array}$ & Local name or number & $\begin{array}{c}\text { Source of } \\
\text { water-level data }\end{array}$ & $\begin{array}{c}\text { USGS } \\
\text { identification number }\end{array}$ \\
\hline 1 & 1 & Lake Yale & USGS & 02238200 \\
\hline 1 & 2 & do. & do. & do. \\
\hline 2 & 1 & do. & do. & do. \\
\hline 2 & 2 & do. & do. & do. \\
\hline 2 & 3 & do. & do. & do. \\
\hline 3 & 3 & do. & do. & do. \\
\hline 3 & 16 & Blackwater Creek near Cassia & do. & 02235200 \\
\hline 4 & 1 & Lake Eustis & do. & 02237900 \\
\hline 4 & 2 & do. & do. & do. \\
\hline 4 & 3 & do. & do. & do. \\
\hline 4 & 4 & do. & do. & do. \\
\hline 5 & 1 & do. & do. & do. \\
\hline 5 & 2 & do. & do. & do. \\
\hline 5 & 3 & do. & do. & do. \\
\hline 6 & 1 & do. & do. & do. \\
\hline 6 & 2 & do. & do. & do. \\
\hline 7 & 1 & do. & do. & do. \\
\hline 4 & 28 & Lake Monroe & do. & 02234499 \\
\hline 4 & 29 & do. & do. & do. \\
\hline 4 & 30 & do. & do. & do. \\
\hline 5 & 27 & do. & do. & do. \\
\hline 5 & 28 & do. & do. & do. \\
\hline 5 & 29 & do. & do. & do. \\
\hline 5 & 30 & do. & do. & do. \\
\hline 5 & 31 & do. & do. & do. \\
\hline 6 & 27 & do. & do. & do. \\
\hline 6 & 28 & do. & do. & do. \\
\hline 6 & 29 & do. & do. & do. \\
\hline 6 & 30 & do. & do. & do. \\
\hline 6 & 31 & do. & do. & do. \\
\hline 6 & 32 & do. & do. & do. \\
\hline 7 & 29 & do. & do. & do. \\
\hline 7 & 30 & do. & do. & do. \\
\hline 7 & 31 & do. & do. & do. \\
\hline 7 & 32 & do. & do. & do. \\
\hline 6 & 5 & West Crooked Lake & do. & 02237753 \\
\hline 7 & 14 & Mt. Plymouth Lake & do. & 02235260 \\
\hline 7 & 20 & Wekiva River near Sanford & do. & 02235000 \\
\hline 7 & 22 & Lake Sylvan & SEMCO & --- \\
\hline 7 & 23 & do. & do. & --- \\
\hline 8 & 23 & do. & do. & --- \\
\hline 8 & 2 & Lake Dora & USGS & 02237800 \\
\hline 8 & 3 & do. & do. & do. \\
\hline 8 & 4 & do. & do. & do. \\
\hline 8 & 5 & do. & do. & do. \\
\hline 8 & 6 & do. & do. & do. \\
\hline 9 & 2 & do. & do. & do. \\
\hline 9 & 3 & do. & do. & do. \\
\hline 9 & 4 & do. & do. & do. \\
\hline 9 & 5 & do. & do. & do. \\
\hline
\end{tabular}


Appendix B. Names and locations of lakes and streams used in this study--Continued

[USGS, U.S. Geological Survey; SEMCO, Seminole County; OCPUD, Orange County Public Utilities Department; do., same; ---, no data]

\begin{tabular}{|c|c|c|c|c|}
\hline $\begin{array}{c}\text { Model } \\
\text { row }\end{array}$ & $\begin{array}{l}\text { Model } \\
\text { column }\end{array}$ & Local name or number & $\begin{array}{c}\text { Source of } \\
\text { water-level data }\end{array}$ & $\begin{array}{c}\text { USGS } \\
\text { identification number }\end{array}$ \\
\hline 9 & 23 & Island Lake & SEMCO & --- \\
\hline 9 & 35 & Lake Jessup & USGS & 02234434 \\
\hline 10 & 34 & do. & do. & do. \\
\hline 10 & 35 & do. & do. & do. \\
\hline 11 & 33 & do. & do. & do. \\
\hline 11 & 34 & do. & do. & do. \\
\hline 11 & 35 & do. & do. & do. \\
\hline 12 & 32 & do. & do. & do. \\
\hline 12 & 33 & do. & do. & do. \\
\hline 12 & 34 & do. & do. & do. \\
\hline 13 & 29 & do. & do. & do. \\
\hline 13 & 30 & do. & do. & do. \\
\hline 13 & 31 & do. & do. & do. \\
\hline 13 & 32 & do. & do. & do. \\
\hline 13 & 33 & do. & do. & do. \\
\hline 10 & 7 & Lake Ola & OCPUD & $\ldots$ \\
\hline 10 & 8 & do. & do. & --- \\
\hline 11 & 22 & Lake Linden & SEMCO & --- \\
\hline 11 & 26 & Lake Mary & USGS/SEMCO & 02234414 \\
\hline 11 & 27 & do. & do. & do. \\
\hline 12 & 4 & Apopka-Beauclaire canal & USGS & 02237700 \\
\hline 12 & 23 & Lake Myrtle & SEMCO & --- \\
\hline 12 & 24 & do. & do. & --- \\
\hline 12 & 27 & Soldier Creek near Longwood & USGS & 02234384 \\
\hline 13 & 16 & Lake Prevatt & OCPUD & --- \\
\hline 13 & 24 & West Lake & SEMCO & --- \\
\hline 13 & 28 & Gee Creek near Longwood & USGS & 02234400 \\
\hline 13 & 43 & St. Johns River above Lake Harney & USGS & 02234000 \\
\hline 12 & 42 & do. & do. & do. \\
\hline 12 & 43 & do. & do. & do. \\
\hline 11 & 41 & do. & do. & do. \\
\hline 11 & 42 & do. & do. & do. \\
\hline 11 & 43 & do. & do. & do. \\
\hline 10 & 41 & do. & do. & do. \\
\hline 10 & 42 & do. & do. & do. \\
\hline 10 & 43 & do. & do. & do. \\
\hline 9 & 42 & do. & do. & do. \\
\hline 9 & 43 & do. & do. & do. \\
\hline 14 & 16 & Lake McCoy & OCPUD & --- \\
\hline 14 & 20 & Lake Brantley & USGS/SEMCO & 02234638 \\
\hline 14 & 23 & 11th-hole pond & do. & $-\cdots$ \\
\hline 15 & 14 & Lake Marshall & OCPUD & --- \\
\hline 15 & 19 & Mirror Lake & SEMCO & --- \\
\hline 15 & 34 & Lake Charm & USGS & 02234428 \\
\hline 15 & 39 & Econlockhatchee River near Chuluota & USGS & 02233500 \\
\hline 15 & 6 & Lake Apopka & USGS & 02237600 \\
\hline 15 & 7 & do. & do. & do. \\
\hline 15 & 8 & do. & do. & do. \\
\hline 15 & 9 & do. & do. & do. \\
\hline 16 & 5 & do. & do. & do. \\
\hline
\end{tabular}


Appendix B. Names and locations of lakes and streams used in this study--Continued

[USGS, U.S. Geological Survey; SEMCO, Seminole County; OCPUD, Orange County Public Utilities Department; do., same; ---, no data]

\begin{tabular}{|c|c|c|c|c|}
\hline $\begin{array}{l}\text { Model } \\
\text { row }\end{array}$ & $\begin{array}{l}\text { Model } \\
\text { column }\end{array}$ & Local name or number & $\begin{array}{c}\text { Source of } \\
\text { water-level data }\end{array}$ & $\begin{array}{c}\text { USGS } \\
\text { identification number }\end{array}$ \\
\hline 16 & 6 & do. & do. & do. \\
\hline 16 & 7 & do. & do. & do. \\
\hline 16 & 8 & do. & do. & do. \\
\hline 16 & 9 & do. & do. & do. \\
\hline 16 & 10 & do. & do. & do. \\
\hline 17 & 4 & do. & do. & do. \\
\hline 17 & 5 & do. & do. & do. \\
\hline 17 & 6 & do. & do. & do. \\
\hline 17 & 7 & do. & do. & do. \\
\hline 17 & 8 & do. & do. & do. \\
\hline 17 & 9 & Lake Apopka & USGS & 02237600 \\
\hline 17 & 10 & do. & do. & do. \\
\hline 17 & 11 & do. & do. & do. \\
\hline 18 & 4 & do. & do. & do. \\
\hline 18 & 5 & do. & do. & do. \\
\hline 18 & 6 & do. & do. & do. \\
\hline 18 & 7 & do. & do. & do. \\
\hline 18 & 8 & do. & do. & do. \\
\hline 18 & 9 & do. & do. & do. \\
\hline 18 & 10 & do. & do. & do. \\
\hline 18 & 11 & do. & do. & do. \\
\hline 18 & 12 & do. & do. & do. \\
\hline 19 & 5 & do. & do. & do. \\
\hline 19 & 6 & do. & do. & do. \\
\hline 19 & 7 & do. & do. & do. \\
\hline 19 & 8 & do. & do. & do. \\
\hline 19 & 9 & do. & do. & do. \\
\hline 19 & 10 & do. & do. & do. \\
\hline 19 & 11 & do. & do. & do. \\
\hline 19 & 12 & do. & do. & do. \\
\hline 20 & 6 & do. & do. & do. \\
\hline 20 & 7 & do. & do. & do. \\
\hline 20 & 8 & do. & do. & do. \\
\hline 20 & 9 & do. & do. & do. \\
\hline 20 & 10 & do. & do. & do. \\
\hline 20 & 11 & do. & do. & do. \\
\hline 21 & 7 & do. & do. & do. \\
\hline 21 & 8 & do. & do. & do. \\
\hline 21 & 9 & do. & do. & do. \\
\hline 21 & 10 & do. & do. & do. \\
\hline 22 & 5 & do. & do. & do. \\
\hline 22 & 6 & do. & do. & do. \\
\hline 22 & 7 & do. & do. & do. \\
\hline 22 & 8 & do. & do. & do. \\
\hline 22 & 9 & do. & do. & do. \\
\hline 16 & 18 & Bear Lake & USGS/SEMCO & 02234942 \\
\hline 16 & 19 & do. & do. & do. \\
\hline 17 & 18 & do. & do. & do. \\
\hline 17 & 19 & do. & do. & do. \\
\hline 16 & 22 & Crane's Roost & SEMCO & - \\
\hline
\end{tabular}


Appendix B. Names and locations of lakes and streams used in this study--Continued

[USGS, U.S. Geological Survey; SEMCO, Seminole County; OCPUD, Orange County Public Utilities Department; do., same; ---, no data]

\begin{tabular}{|c|c|c|c|c|}
\hline $\begin{array}{l}\text { Model } \\
\text { row }\end{array}$ & $\begin{array}{l}\text { Model } \\
\text { column }\end{array}$ & Local name or number & $\begin{array}{c}\text { Source of } \\
\text { water-level data }\end{array}$ & $\begin{array}{c}\text { USGS } \\
\text { identification number }\end{array}$ \\
\hline 16 & 23 & Lake Oreinta & USGS/SEMCO & 02234943 \\
\hline 17 & 20 & Lake Bosse & OCPUD & --- \\
\hline 17 & 26 & Lake Howell & SEMCO & --- \\
\hline 17 & 27 & do. & do. & --- \\
\hline 17 & 28 & do. & do. & --- \\
\hline 17 & 30 & Howell Creek near Slavia & USGS & 02234324 \\
\hline 17 & 38 & Lake Catherine & SEMCO & --- \\
\hline 18 & 18 & Long Lake & OCPUD & $\ldots$ \\
\hline 18 & 19 & Lake Lockhart & do. & -- \\
\hline 18 & 23 & Lake Sybelia & do. & -- \\
\hline 18 & 24 & Lake Maitland & USGS/OCPUD & 02234300 \\
\hline 18 & 25 & do. & OCPUD & --- \\
\hline 19 & 24 & do. & do. & --- \\
\hline 19 & 25 & do. & do. & -- \\
\hline 18 & 26 & Howell Branch Creek & SEMCO & --- \\
\hline 18 & 29 & Bear Gully Lake & do. & $\ldots$ \\
\hline 19 & 20 & Lake Wekiva near Maitland & USGS & 02234814 \\
\hline 19 & 23 & Park \& Gem & OCPUD & --. \\
\hline 19 & 29 & Lake Wannata & do. & $\ldots$ \\
\hline 20 & 20 & Bay Lake & do. & -- \\
\hline 20 & 21 & Lake Fairview & do. & -- \\
\hline 20 & 24 & Lake Virginia & do. & $\ldots$ \\
\hline 20 & 25 & Lake Mizell & do. & -- \\
\hline 20 & 35 & Lake Price & do. & --- \\
\hline 21 & 22 & Lake Silver & do. & $\ldots$ \\
\hline 21 & 23 & Lake Formosa & do. & -- \\
\hline 21 & 24 & Lake Sue & do. & -- \\
\hline 21 & 26 & Lake Baldwin & do. & $\cdots$ \\
\hline 22 & 15 & Lake Lotta & do. & --- \\
\hline 22 & 16 & Lake Sherwood & do. & -- \\
\hline 23 & 16 & do. & do. & $\ldots$ \\
\hline 22 & 22 & Spring Lake (NOBT) & do. &.-- \\
\hline 22 & 26 & Lake Savannah & do. & -- \\
\hline 22 & 27 & Lake Barton & do. & --- \\
\hline 23 & 15 & Lake Rose & do. & -- \\
\hline 23 & 20 & Lake Mann & do. & --- \\
\hline 24 & 20 & do. & do, & --- \\
\hline 23 & 25 & Lake Underhill & do. & --- \\
\hline 23 & 49 & St. Johns River near Christmas & USGS & 02232500 \\
\hline 24 & 5 & Johns Lake & do. & 02237540 \\
\hline 24 & 6 & do. & do. & do. \\
\hline 24 & 7 & do. & do. & do. \\
\hline 24 & 9 & Black Lake & OCPUD & -- \\
\hline 24 & 21 & Clear Lake & do. & -.- \\
\hline 24 & 30 & Little Econ near Union Park & USGS & 02236820 \\
\hline 25 & 7 & Lake Avalon & OCPUD & -.- \\
\hline 25 & 12 & Crescent Lake & do. & --- \\
\hline 25 & 21 & Lake Tyler & do. & --- \\
\hline 26 & 1 & Lake Louisa & USGS & 02236820 \\
\hline 26 & 2 & do. & do. & do. \\
\hline
\end{tabular}


Appendix B. Names and locations of lakes and streams used in this study--Continued

[USGS, U.S. Geological Survey; SEMCO, Seminole County; OCPUD, Orange County Public Utilities Department; do., same; ---, no data]

\begin{tabular}{|c|c|c|c|c|}
\hline $\begin{array}{l}\text { Model } \\
\text { row }\end{array}$ & $\begin{array}{l}\text { Model } \\
\text { column }\end{array}$ & Local name or number & $\begin{array}{c}\text { Source of } \\
\text { water-level data }\end{array}$ & $\begin{array}{c}\text { USGS } \\
\text { identification number }\end{array}$ \\
\hline 27 & 1 & do. & do. & do. \\
\hline 27 & 2 & do. & do. & do. \\
\hline 28 & 1 & do. & do. & do. \\
\hline 28 & 2 & do. & do. & do. \\
\hline 26 & 5 & Flat Lake & OCPUD & --- \\
\hline 26 & 12 & Lake Butler & USGS & 02263900 \\
\hline 26 & 13 & do. & do. & do. \\
\hline 27 & 12 & do. & do. & do. \\
\hline 27 & 13 & do. & do. & do. \\
\hline 26 & 14 & Lake Down & OCPUD & -- \\
\hline 26 & 17 & Lake Cain & do. & --- \\
\hline 26 & 23 & Lake Jennie Jewell & do. & -- \\
\hline 26 & 25 & Lake Anderson & do. & -- \\
\hline 27 & 9 & Lake Speer & do. & --- \\
\hline 27 & 10 & do. & do. & --- \\
\hline 27 & 16 & Palm Lake & do. & -- \\
\hline 27 & 17 & Lake Marsha & do. & -- \\
\hline 27 & 22 & Lake Jessamine & do. & --- \\
\hline 27 & 23 & Lake Mary Jess & do. & --- \\
\hline 27 & 24 & Lake Conway & USGS & 02262800 \\
\hline 28 & 3 & Trout Lake & do. & 02266239 \\
\hline 28 & 7 & Lake Ingram & OCPUD & -- \\
\hline 28 & 9 & Lake Hancock & do. & --- \\
\hline 28 & 14 & Lake Tibet & do. & --- \\
\hline 28 & 15 & do. & do. & --- \\
\hline 28 & 16 & Spring Lake & do. & --- \\
\hline 28 & 17 & do. & do. & --- \\
\hline 28 & 23 & Bearhead Lake & do. & --- \\
\hline 29 & 1 & Big Creek near Clermont & USGS & 02236500 \\
\hline 29 & 5 & Sawgrass Lake & OCPUD & -- \\
\hline 30 & 5 & do. & do. & $\cdots$ \\
\hline 30 & 6 & do. & do. & -- \\
\hline 29 & 6 & Lake Needham & do. & --- \\
\hline 29 & 9 & Lake Huckleberry & do. & -- \\
\hline 30 & 6 & Hickory Nut Lake & do. & -- \\
\hline 30 & 7 & do. & do. & $\cdots$ \\
\hline 30 & 16 & Big Sand Lake & do. & -- \\
\hline 31 & 16 & do. & do. & --- \\
\hline 30 & 39 & Econlockhatchee River at Magnolia Ranch & USGS & 02233001 \\
\hline 31 & 9 & Reedy Creek at SR46 & do. & 02266025 \\
\hline 31 & 12 & Bay Lake & do. & 02263850 \\
\hline 31 & 15 & Fish Lake & OCPUD & -- \\
\hline 32 & 8 & Whittenhorse Creek near Vineland & USGS & 02266200 \\
\hline 32 & 14 & Cypress Creek at Vineland & do. & 02264000 \\
\hline 32 & 33 & Lake Mary Jane/Lake Hart & do. & 02261900 \\
\hline 33 & 33 & do. & do. & do. \\
\hline 33 & 34 & do. & do. & do. \\
\hline 33 & 35 & do. & do. & do. \\
\hline 34 & 35 & do. & do. & do. \\
\hline 33 & 27 & Boggy Creek near Taft & do. & 02262900 \\
\hline
\end{tabular}


Appendix B. Names and locations of lakes and streams used in this study--Continued

[USGS, U.S. Geological Survey; SEMCO, Seminole County; OCPUD, Orange County Public Utilities Department; do.. same; ---, no data]

\begin{tabular}{|c|c|c|c|c|}
\hline $\begin{array}{l}\text { Model } \\
\text { row }\end{array}$ & $\begin{array}{l}\text { Model } \\
\text { column }\end{array}$ & Local name or number & $\begin{array}{c}\text { Source of } \\
\text { water-level data }\end{array}$ & $\begin{array}{c}\text { USGS } \\
\text { identification number }\end{array}$ \\
\hline 33 & 53 & St. Johns River near Cocoa & do. & 02232400 \\
\hline 34 & 54 & Lake Poinsett & do. & 02232300 \\
\hline 35 & 54 & do. & do. & do. \\
\hline 35 & 55 & do. & do. & do. \\
\hline 36 & 11 & Reedy Creek near Vineland & do. & 02266300 \\
\hline 36 & 14 & Bonnett Creek near Vineland & do. & 02264100 \\
\hline 37 & 4 & Green Swamp run near Eva & do. & 02236350 \\
\hline 37 & 18 & Shingle Creek at airport & do. & 0263800 \\
\hline 38 & 21 & Lake Tohopekaliga & USGS & 02264495 \\
\hline 38 & 22 & do. & do. & do. \\
\hline 38 & 23 & do. & do. & do. \\
\hline 39 & 21 & do. & do. & do. \\
\hline 39 & 22 & do. & do. & do. \\
\hline 39 & 23 & do. & do. & do. \\
\hline 40 & 21 & do. & do. & do. \\
\hline 40 & 22 & do. & do. & do. \\
\hline 40 & 23 & do. & do. & do. \\
\hline 39 & 10 & Davenport Creek near Loughman & do. & 02266480 \\
\hline 39 & 13 & Reedy Creek at SR40 & do. & 02266495 \\
\hline 39 & 19 & Shingle Creek near Campbell & do. & 02264495 \\
\hline 40 & 13 & Reedy Creek near Loughman & do. & 02266500 \\
\hline
\end{tabular}


Appendix C. Locations of and average daily withdrawal rates from Floridan aquifer municipal/industrial/commercial well fields used in ground-water flow model for 1988, December 1989 through May 1990, and projected 2010 simulations

[All values in cubic feet per second. OCPUD, Orange County Public Utilities Department; OUC, Orlando Utilities Commission]

\begin{tabular}{|c|c|c|c|c|c|c|c|c|c|c|}
\hline \multirow[b]{2}{*}{ Well field/well owner name } & \multicolumn{2}{|c|}{ Model } & \multirow[b]{2}{*}{1988} & \multirow{2}{*}{ 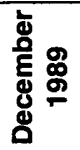 } & \multirow{2}{*}{ 㟨 } & \multirow{2}{*}{ 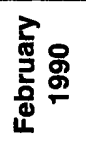 } & \multirow[b]{2}{*}{$\begin{array}{l}\text { ঠ 용 } \\
\text { 일 }\end{array}$} & \multirow[b]{2}{*}{ 동영 } & \multirow[b]{2}{*}{ 출용 } & \multirow[b]{2}{*}{$2010^{\mathrm{a}}$} \\
\hline & Row & $\begin{array}{l}\text { Col- } \\
\text { umn }\end{array}$ & & & & & & & & \\
\hline
\end{tabular}

Source Aquifer: Upper Floridan

ORANGE COUNTY

All Gator Carrot Company

Amcon Products, Inc.

Apopka (Grossenbacher)

Aquacult. Food Farms, Inc.

Bruce C. Goren

E. Carroll-RV Park

Central Florida Research Pk

Cocoa (well 10)

Cocoa (wells 1, 2)

Cocoa (wells 8, 9)

Cocoa (wells 16,17)

Cocoa (wells 14,15)

Cocoa (well 13)

Cocoa (well 7A)

Cocoa (wells 3,7)

Cocoa (wells 18,19)

Cocoa (wells 4, 4A1, 5, 12B)

Cocoa (well 12A)

Cocoa (well 11)

Cocoa (well 20)

Cocoa (well 21)

Cocoa (well 22)

Cocoa (well 31)

Cocoa (well 32)

Cocoa (well 33)

Cocoa (well 38)

Cocoa (well 39)

Cocoa (well 40)

Cocoa (well 41)

Cocoa (well 42)

Cocoa (well 43)

Cocoa (well 44)

Cocoa Cola (Plymouth Plant)

Spencer G. Douglas

Eatonville, City of

Econ Util (Wedgefield)

Fla Dept of Correction

Fla Mining \& Materials

Fla Mining \& Materials

Frito-Lay, Inc.

G G Products

Hydro Conduit Corp

Robert E. Lee

Maitland, City of (Thistle)

Maitland, City of (Wymore5)

Maitland, City of (Swoope)

Maitland, City of (Minnehaha)

Maitland, City of (Adios)

Maitland, City of (Wymore5A)

Oakland, City of

\begin{tabular}{|c|c|c|c|c|c|c|c|c|c|}
\hline 15 & 12 & 0.178 & 0.178 & 0.178 & 0.178 & 0.178 & 0.178 & 0.178 & 0.186 \\
\hline 21 & 11 & .040 & .040 & .040 & .040 & .040 & .040 & .040 & .040 \\
\hline 14 & 15 & 1.070 & 1.151 & 1.175 & 1.070 & 1.417 & 1.427 & 1.742 & 3.842 \\
\hline 14 & 11 & .172 & .172 & .172 & .172 & .172 & .172 & .172 & .186 \\
\hline 32 & 5 & 0 & 0 & 0 & 0 & 0 & 0 & 0 & .387 \\
\hline 14 & 11 & .025 & .025 & .025 & .025 & .025 & .025 & .025 & .031 \\
\hline 21 & 34 & 0 & 0 & 0 & 0 & 0 & 0 & 0 & 1.547 \\
\hline 28 & 40 & .364 & .447 & .464 & .465 & .455 & .468 & .460 & .232 \\
\hline 29 & 40 & .138 & .059 & .059 & .048 & .525 & .234 & .600 & .603 \\
\hline 29 & 40 & .601 & .751 & .778 & .603 & .910 & .791 & .855 & .742 \\
\hline 30 & 36 & 10.840 & 9.630 & 9.980 & 9.989 & 9.880 & 9.980 & 10.190 & 5.415 \\
\hline 30 & 37 & 10.310 & 4.561 & 4.731 & 4.983 & 5.070 & 5.150 & 5.120 & 5.291 \\
\hline 30 & 38 & 2.940 & .428 & .444 & 2.339 & 3.400 & 2.210 & 3.150 & .928 \\
\hline 30 & 39 & .426 & .279 & .289 & 1.244 & 1.385 & 1.430 & 1.490 & .402 \\
\hline 30 & 40 & 1.025 & .936 & .969 & .874 & 1.110 & 1.253 & 1.415 & .371 \\
\hline 31 & 36 & 7.030 & 4.401 & 4.565 & 8.881 & 10.640 & 10.850 & 10.850 & 5.786 \\
\hline 31 & 40 & 3.213 & 4.869 & 5.051 & 1.477 & 3.085 & 4.970 & 3.970 & 1.484 \\
\hline 31 & 41 & .497 & .769 & .798 & .171 & 0 & .228 & .730 & .371 \\
\hline 32 & 40 & 1.440 & .957 & .993 & .708 & 1.090 & 1.120 & .955 & .371 \\
\hline 31 & 36 & 0 & 0 & 0 & 0 & 0 & 0 & 0 & 2.893 \\
\hline 31 & 36 & 0 & 0 & 0 & 0 & 0 & 0 & 0 & 2.893 \\
\hline 32 & 36 & 0 & 0 & 0 & 0 & 0 & 0 & 0 & 2.893 \\
\hline 32 & 36 & 0 & 0 & 0 & 0 & 0 & 0 & 0 & 2.893 \\
\hline 32 & 36 & 0 & 0 & 0 & 0 & 0 & 0 & 0 & 2.893 \\
\hline 32 & 36 & 0 & 0 & 0 & 0 & 0 & 0 & 0 & 2.893 \\
\hline 32 & 40 & 0 & 0 & 0 & 0 & 0 & 0 & 0 & .371 \\
\hline 32 & 40 & 0 & 0 & 0 & 0 & 0 & 0 & 0 & .371 \\
\hline 33 & 40 & 0 & 0 & 0 & 0 & 0 & 0 & 0 & .371 \\
\hline 33 & 40 & 0 & 0 & 0 & 0 & 0 & 0 & 0 & .371 \\
\hline 33 & 40 & 0 & 0 & 0 & 0 & 0 & 0 & 0 & .371 \\
\hline 34 & 40 & 0 & 0 & 0 & 0 & 0 & 0 & 0 & .371 \\
\hline 34 & 40 & 0 & 0 & 0 & 0 & 0 & 0 & 0 & .371 \\
\hline 14 & 12 & .163 & .267 & .241 & .128 & .180 & .188 & .167 & .170 \\
\hline 12 & 9 & .053 & .053 & .053 & .053 & .053 & .053 & .053 & .077 \\
\hline 19 & 23 & .936 & .998 & 1.020 & .993 & 1.100 & 1.010 & 1.230 & 2.181 \\
\hline 25 & 41 & .206 & .219 & .219 & .214 & .260 & .265 & .260 & .248 \\
\hline 28 & 36 & .340 & 0 & 0 & 0 & 0 & 0 & 0 & .372 \\
\hline 19 & 27 & .020 & .020 & .020 & .020 & .020 & .020 & .020 & .030 \\
\hline 8 & 28 & .045 & .045 & .045 & .045 & .045 & .045 & .045 & .046 \\
\hline 21 & 20 & 0 & 0 & 0 & 0 & 0 & 0 & 0 & .232 \\
\hline 14 & 6 & .027 & .027 & .027 & .027 & .027 & .027 & .027 & .045 \\
\hline 17 & 17 & .165 & .165 & .165 & .165 & .165 & .165 & .165 & .170 \\
\hline 14 & 13 & .097 & .097 & .097 & .097 & .097 & .097 & .097 & .139 \\
\hline 17 & 25 & 1.270 & .734 & .720 & .628 & .970 & .890 & 1.280 & 1.083 \\
\hline 18 & 22 & .635 & .862 & .845 & .792 & .835 & .840 & .935 & .727 \\
\hline 18 & 24 & .635 & 0 & 0 & 0 & 0 & 0 & 0 & 0 \\
\hline 18 & 24 & .635 & .142 & .139 & .148 & .282 & .289 & .552 & .170 \\
\hline 18 & 24 & .635 & 0 & 0 & 0 & 0 & 0 & 0 & 0 \\
\hline 18 & 22 & .318 & .431 & .423 & .396 & .417 & .420 & .468 & .364 \\
\hline 22 & 8 & .228 & .153 & .153 & .173 & .188 & .168 & .219 & .232 \\
\hline
\end{tabular}


Appendix C. Locations of and average daily withdrawal rates from Floridan aquifer municipal/industrial/commercial well fields used in ground-water flow model for 1988, December 1989 through May 1990, and projected 2010 simulations--Continued

[All values in cubic feet per second. OCPUD, Orange County Public Utilities Department; OUC, Orlando Utilities Commission]

\begin{tabular}{|c|c|c|c|c|c|c|c|c|c|c|}
\hline \multirow[b]{2}{*}{ Well field/well owner name } & \multicolumn{2}{|c|}{ Model } & \multirow[b]{2}{*}{1988} & \multirow{2}{*}{ 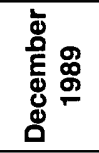 } & \multirow{2}{*}{$\begin{array}{l}\text { 롱 } \\
\text { 롱 } \\
\text { 용 }\end{array}$} & \multirow{2}{*}{ 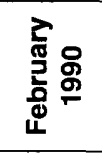 } & \multirow{2}{*}{$\begin{array}{l}\text { 든 } \\
\text { 율 }\end{array}$} & \multirow[b]{2}{*}{ 흥영 } & \multirow[b]{2}{*}{ 촐 } & \multirow[b]{2}{*}{$2010^{\mathrm{a}}$} \\
\hline & Row & $\begin{array}{l}\text { Col- } \\
\text { umn }\end{array}$ & & & & & & & & \\
\hline Ocoee, City of (Hackney) & 20 & 14 & .886 & .722 & .590 & .596 & .740 & .545 & 1.140 & 1.052 \\
\hline Ocoee, City of (Kissimmee St) & 22 & 13 & 1.030 & .953 & 1.120 & .999 & 1.560 & 1.560 & 1.890 & 1.439 \\
\hline Ocoee, City of (Wurst Rd.) & 20 & 15 & 1.382 & 1.164 & 1.680 & 1.680 & 2.250 & 2.260 & 2.610 & 1.439 \\
\hline OCPUD (Bent Oaks) & 14 & 17 & 2.040 & 1.936 & 2.240 & 2.340 & 2.720 & 2.540 & 3.520 & 0 \\
\hline OCPUD (Bonneville) & 20 & 34 & 1.150 & 3.314 & 3.510 & 3.170 & 3.470 & 3.350 & 4.090 & 0 \\
\hline OCPUD (Conway) & 26 & 27 & 3.440 & 3.330 & 3.360 & 2.754 & 4.044 & 2.469 & 2.271 & 9.699 \\
\hline OCPUD (Corrine Terrace) & 21 & 27 & .310 & .434 & 0 & 0 & 0 & 0 & 0 & 0 \\
\hline OCPUD (Cypress Walk) & 32 & 14 & .880 & 1.051 & 1.250 & 1.210 & 1.440 & 1.400 & 1.640 & 3.867 \\
\hline OCPUD (Eastern Regional) & 25 & 30 & 0 & 0 & 0 & 0 & 0 & 0 & 0 & 31.250 \\
\hline OCPUD (Econ) & 23 & 30 & 5.530 & 5.296 & 5.460 & 5.520 & 6.620 & 8.348 & 12.200 & 12.376 \\
\hline OCPUD (Hidden Springs) & 26 & 16 & .365 & .448 & .613 & .582 & .771 & .757 & 1.014 & 0 \\
\hline OCPUD (Hunters Creek) & 34 & 19 & .184 & .921 & .977 & .764 & 1.690 & 1.790 & 2.420 & .774 \\
\hline OCPUD (Kelso) & 26 & 11 & .025 & .031 & .036 & .025 & .036 & .031 & .051 & 0 \\
\hline OCPUD (Lake John Shores) & 23 & 8 & 0 & 0 & 0 & 0 & 0 & 0 & 0 & .046 \\
\hline OCPUD (Lake Nona) & 30 & 30 & .052 & .087 & .092 & .087 & .122 & .132 & .163 & 3.094 \\
\hline OCPUD (Magnolia Woods) & 20 & 11 & .059 & .051 & .056 & .056 & .076 & .071 & .117 & .046 \\
\hline OCPUD (Meadow Woods) & 33 & 24 & .118 & .179 & .199 & .209 & .244 & .244 & .458 & .309 \\
\hline OCPUD (Mt. Plymouth Lakes) & 10 & 14 & .295 & .260 & .283 & .250 & .434 & .420 & .581 & 1.392 \\
\hline OCPUD (Oak Meadows) & 23 & 16 & 1.500 & 1.982 & 2.120 & 1.850 & 1.760 & 2.885 & 2.770 & 0 \\
\hline OCPUD (Orange Village) & 17 & 15 & .031 & .031 & .031 & .020 & .020 & .025 & .025 & .046 \\
\hline OCPUD (Orange Wood) & 30 & 18 & 1.830 & 1.661 & 1.889 & 1.842 & 1.963 & 2.164 & 2.171 & 7.426 \\
\hline OCPUD (Plymouth) & 13 & 12 & 0 & 0 & 0 & 0 & 0 & 0 & 0 & 2.321 \\
\hline OCPUD (Plymouth Central) & 14 & 12 & 0 & .239 & .239 & .219 & .280 & .316 & .326 & 0 \\
\hline OCPUD (Plymouth Hills) & 14 & 12 & .164 & .285 & .285 & .280 & .433 & .305 & .580 & 0 \\
\hline OCPUD (Riverside) & 17 & 20 & 3.000 & 3.534 & 3.122 & 2.760 & 4.663 & 4.623 & 6.130 & 0 \\
\hline OCPUD (Vistana) & 34 & 15 & 1.620 & 1.598 & 1.720 & 1.570 & 1.760 & 1.790 & 1.910 & 6.188 \\
\hline OCPUD (Wauseon Ridge) & 25 & 13 & .045 & 0 & 0 & 0 & 0 & 0 & 0 & 0 \\
\hline OCPUD (Windermere) & 26 & 13 & .022 & 0 & 0 & 0 & 0 & 0 & 0 & 0 \\
\hline OCPUD (Windermere Downs) & 24 & 14 & .344 & 0 & 0 & 0 & 0 & 0 & 0 & 0 \\
\hline Omer A. Schrock & 10 & 1 & 0 & 0 & 0 & 0 & 0 & 0 & 0 & .325 \\
\hline Orange Villa & 25 & 8 & .057 & .057 & .057 & .057 & .057 & .057 & .057 & .062 \\
\hline OUC (Dr. Phillips) & 28 & 16 & 8.250 & 6.660 & 7.720 & 6.760 & 10.030 & 9.640 & 12.000 & 9.592 \\
\hline OUC (Martin) & 29 & 19 & 14.190 & 13.572 & 14.751 & 14.100 & 17.100 & 16.899 & 18.000 & 31.233 \\
\hline OUC (Stanton Energy Center) & 27 & 35 & .309 & .332 & .298 & .267 & .346 & .196 & .295 & .309 \\
\hline OUC (Stanton Energy Center) & 27 & 36 & .309 & .332 & .297 & .267 & .346 & .196 & .295 & .309 \\
\hline Park Manor Water Works & 22 & 32 & .347 & .347 & .347 & .347 & .347 & .347 & .347 & .309 \\
\hline Park Manor Water Works & 22 & 31 & .348 & .348 & .348 & .348 & .348 & .348 & .348 & .309 \\
\hline Ralston Purina (Zellwood Fms) & 15 & 12 & 0 & 0 & 0 & 0 & 0 & 0 & .0 & .232 \\
\hline Reedy Creek (Station B) & 34 & 12 & 6.500 & 8.304 & 8.030 & 7.430 & 9.090 & 8.980 & 10.100 & 14.341 \\
\hline Reedy Creek (Station A) & 30 & 11 & 6.910 & 6.637 & 6.590 & 7.200 & 8.850 & 8.640 & 9.670 & 20.653 \\
\hline Reedy Creek (Station C) & 32 & 14 & 1.620 & 1.412 & 2.780 & 2.680 & 3.260 & 3.250 & 3.330 & 9.901 \\
\hline Rinker Materials Corp & 19 & 20 & .032 & .032 & .032 & .032 & .032 & .032 & .032 & .032 \\
\hline Rock Springs MHP & 13 & 15 & .305 & .405 & .366 & .361 & .478 & .433 & .540 & .433 \\
\hline Sea World of Florida & 31 & 17 & 2.420 & 2.440 & 2.440 & 2.180 & 2.390 & 2.390 & 2.430 & 2.011 \\
\hline Shadow Hills MHP & 22 & 29 & .301 & 0 & 0 & 0 & 0 & 0 & 0 & .309 \\
\hline Southern Fruit Distributors & 25 & 23 & .205 & .046 & .046 & 0 & 0 & 0 & 0 & .217 \\
\hline Southern Gold Citrus Prod & 21 & 20 & .018 & .018 & .018 & .018 & .018 & .018 & .018 & 0 \\
\hline So.States Util (Dartwyler) & 28 & 25 & .082 & .092 & .092 & .087 & .102 & .112 & .122 & .124 \\
\hline So.States Util (Dol Ray) & 18 & 15 & .067 & .067 & .067 & .067 & .072 & .072 & .085 & .062 \\
\hline So.States Util (Lk.Conway Pk) & 28 & 25 & .040 & .036 & .036 & .036 & .046 & .041 & .056 & .062 \\
\hline So.States Util (Suncrest) & 21 & 29 & .206 & .494 & .494 & .382 & .550 & .550 & .687 & 1.083 \\
\hline So.States Util (Univ.Shores) & 20 & 31 & .812 & .774 & .774 & .718 & .830 & .769 & 1.040 & 1.300 \\
\hline Starlight Ranch MHP & 26 & 27 & .256 & .265 & .265 & .244 & .316 & .285 & .372 & .356 \\
\hline Sun Resorts (Yogi Bear) & 17 & 15 & .266 & .489 & .544 & .196 & .283 & .280 & .281 & .232 \\
\hline Taft Water Association & 30 & 23 & .361 & .422 & .422 & .356 & .443 & .422 & .534 & 0 \\
\hline
\end{tabular}


Appendix C. Locations of and average daily withdrawal rates from Floridan aquifer municipal/industrial/commercial well fields used in ground-water flow model for 1988, December 1989 through May 1990, and projected 2010 simulations--Continued

[All values in cubic feet per second. OCPUD, Orange County Public Utilities Department; OUC, Orlando Utilities Commission]

\begin{tabular}{|c|c|c|c|c|c|c|c|c|c|c|}
\hline \multirow[b]{2}{*}{ Well field/well owner name } & \multicolumn{2}{|c|}{ Modei } & \multirow[b]{2}{*}{1988} & \multirow{2}{*}{ 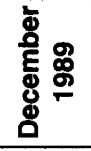 } & \multirow{2}{*}{ 胥 } & \multirow{2}{*}{ 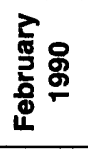 } & \multirow[b]{2}{*}{ 동 용 } & \multirow[b]{2}{*}{ 든 } & \multirow[b]{2}{*}{ 홀 } & \multirow[b]{2}{*}{$2010^{\mathrm{a}}$} \\
\hline & Row & $\begin{array}{l}\text { Col- } \\
\text { umn }\end{array}$ & & & & & & & & \\
\hline Tangerine, Town of & 10 & 8 & .208 & .193 & .193 & .183 & .265 & .229 & .285 & 0 \\
\hline Turkey Lake Park & 25 & 16 & 0 & 0 & 0 & 0 & 0 & 0 & 0 & .093 \\
\hline University Central Florida & 19 & 33 & 1.120 & 1.032 & .838 & .809 & .923 & 1.040 & 1.310 & .556 \\
\hline University Central Florida & 20 & 34 & .390 & .120 & .295 & .285 & .325 & .365 & .460 & .834 \\
\hline University Central Florida & 20 & 33 & .065 & .020 & .047 & .046 & .052 & .055 & .070 & .278 \\
\hline Uniwes, Inc. & 19 & 15 & .106 & .106 & .106 & .106 & .106 & .106 & .106 & .108 \\
\hline Util of Fla (Crescent Hghts) & 23 & 18 & .149 & .117 & .117 & .153 & .153 & .148 & .173 & 0 \\
\hline Util of Fla (Davis Shores) & 25 & 13 & .020 & .020 & .020 & .020 & .030 & .030 & .036 & .031 \\
\hline H.J. White & 17 & 18 & .066 & .066 & .066 & .066 & .066 & .066 & .066 & .093 \\
\hline Winter Garden (Boyd Street) & 22 & 10 & .870 & 1.230 & 1.270 & 1.250 & 1.610 & 1.520 & 1.740 & .975 \\
\hline Winter Garden (Fuller Cross) & 22 & 10 & 0 & 0 & 0 & 0 & 0 & 0 & 0 & .975 \\
\hline Winter Garden Citrus Products & 22 & 11 & 2.890 & 9.180 & 9.180 & 7.530 & 6.340 & 4.590 & 2.320 & 2.893 \\
\hline Winter Park, City of (NY Ave.) & 19 & 24 & 3.740 & 2.446 & 2.920 & 2.940 & 3.600 & 2.250 & 3.580 & 3.496 \\
\hline Zellwood Farms & 10 & 9 & .234 & .255 & .255 & .232 & .205 & .205 & .289 & .495 \\
\hline Zellwood Station & 12 & 10 & .092 & .165 & .165 & .158 & .200 & .201 & .222 & .248 \\
\hline Zellwood Station & 12 & 11 & .552 & .990 & .990 & .942 & 1.200 & 1.206 & 1.326 & 1.484 \\
\hline Zellwood Station & 13 & 10 & .092 & .165 & .165 & .158 & .200 & .202 & .221 & .248 \\
\hline Zellwood Water Assoc. & 12 & 9 & .254 & .229 & .229 & .229 & .397 & .346 & .463 & .572 \\
\hline Zellwood MHP & 12 & 11 & & & & & & & & .990 \\
\hline
\end{tabular}

SEMINOLE COUNTY

Altamonte Spgs, City (WTP\#1)

Altamonte Spgs, City (WTP\#2)

$\begin{array}{ll}16 & 24 \\ 17 & 23\end{array}$

Altamonte Spgs, City (WPT\#3)

Altamonte Spgs, City (WTP\#4) )

Altamonte Spgs, City (WTP\#5)

16

Altamonte Spgs, City (Chrlt)

Margaret C. Cammack

Casselberry (South \#1)

Casselberry (Howell Park)

Casselberry, City (North)

0

0

0

0

0

.990

Casselberry Elementary

Central V Util (Hunters Field)

Central V Util (Derbyshire)

Deep South Products

Indian Creek, Inc.

Inland Materials, Inc.

B. Jaffe \& B. Tresser

Keith Elementary

Lake Brantley High School

Lake Harney Water Assoc.

Lake Howell High School

Lake Mary, City of

Lake Mary, City of

Longwood, City of (Plant \#1)

Longwood, City of (Plant \#2)

Lutheran Haven

Mullet Lake Water Assoc.

Oviedo (Alafaya Woods)

Oviedo (Alafaya Woods)

Oviedo, City of (Old)

Oviedo-Prop. well Lake Gem

Oviedo High School

Palm Ventures MHP

L.D. Plante, Inc.

Sanford, City (Wellfield \#1)

.145
4.840
1.080
.529
6.460
0
.070
.963
.800
2.260
.043
.817
.867
.244
.072
.056
.076
.065
.066
.046
.030
.774
0
1.180
1.960
.061
.057
.580
0
1.209
0
.032
.242
.100
4.970

.819
2.400
1.370
1.090
6.030
0
.070
.560
1.527
1.220
.043
.550
1.060
.229
.066
.056
.076
.065
.066
.046
.030
1.640
0
.575
2.470
.056
.056
.855
0
1.650
0
.032
.239
.100
3.920

.387

5.000

0

1.270

3.790

0

0

.070

.605

1.649

1.318

.043

.588

1.086

.229

.051

.056

.076

.065

.066

.052

.030

1.594

0

.481

2.704

.056

.056

.945

0

1.461

0

.032

.254

.100

3.681

.070

.573

1.087

2.030

.043

.521

.979

.217

.071

.056

.076

.065

.066

.046

.030

1.220

0

.422

2.700

.051

.056

.850

0

1.560

0

3.690
.626
5.850

0

1.700

5.210

0

.070

.793

1.370

2.460

.043

.724

1.110

.239

.107

.056

.076

.065

.066

.060

.387

6.020

0
1.24

1.240
5.380

0

0
.070

.743

1.440

2.150

.043

.670

.980

.204

.127

.056

.076

.065

.066

.046

.030

1.990

0

.453

3.650

.076

.076

1.270

0

.030
1.740

1.74

0

.799
2.840

.071

.066
1.230

1.230

0

0

0
.032

.326

.100

0

.032

.234

.100

4.730

.229
.100

4.410
.060

6.690

0

2.120

6.920

0

.070

.940

2.230

2.360

.043

.900

1.540

.181

.168

.056

.076

.065

.066

.060

.030

2.700

0

.921

0

4.672

4.672

0

6.420

0

.789

1.578

.742

.043

0

.317

.045

.062

.092

.065

.066

.062

.030

2.476

6.190

1.346

$\begin{array}{ll}3.730 & 3.527\end{array}$

$.087 \quad 0$

$.092 \quad .093$

$1.820 \quad 5.693$

$\begin{array}{ll}0 & 2.274\end{array}$

$2.679 \quad 4.671$

$\begin{array}{ll}0 & 2.274\end{array}$

2.274
.032

.356

.108

1.485 
Appendix C. Locations of and average daily withdrawal rates from Floridan aquifer municipal/industrial/commercial well fields used in ground-water flow model for 1988, December 1989 through May 1990, and projected 2010 simulations--Continued

[All values in cubic feet per second. OCPUD, Orange County Public Utilities Department; OUC, Orlando Utilities Commission]

\begin{tabular}{|c|c|c|c|c|c|c|c|c|c|c|}
\hline \multirow[b]{2}{*}{ Well field/well owner name } & \multicolumn{2}{|c|}{ Model } & \multirow[b]{2}{*}{1988} & \multirow{2}{*}{ 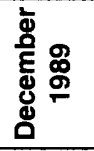 } & \multirow{2}{*}{$\begin{array}{l}\frac{2}{5} \text { 올 } \\
\text { 空 }\end{array}$} & \multirow{2}{*}{ 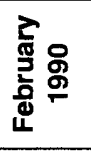 } & \multirow[b]{2}{*}{$\begin{array}{l}\text { 등 영 } \\
\text { 일 }\end{array}$} & \multirow[b]{2}{*}{ 흫ㅇㅇㅇ } & \multirow[b]{2}{*}{ 출 } & \multirow[b]{2}{*}{$2010^{a}$} \\
\hline & Row & $\begin{array}{l}\text { Col- } \\
\text { umn }\end{array}$ & & & & & & & & \\
\hline Sanford, City (Wellfield \#2) & 9 & 26 & 2.810 & 3.440 & .324 & .462 & 1.080 & .444 & .603 & 2.537 \\
\hline Sanford, City (Wellfield \#3) & 8 & 26 & 1.280 & 1.767 & 4.130 & 3.450 & 3.800 & 3.740 & 4.970 & 5.028 \\
\hline Sanlando (Despinar) & 13 & 23 & 5.110 & 4.756 & 5.270 & 5.040 & 7.100 & 6.990 & 9.350 & 5.444 \\
\hline Sanlando (Knollwood) & 14 & 23 & .138 & 0.290 & .158 & .153 & .300 & .290 & .590 & .139 \\
\hline Sanlando (Wekiva) & 14 & 19 & 8.835 & 8.225 & 8.780 & 8.210 & 10.470 & 10.890 & 13.050 & 11.060 \\
\hline Seminole Co. (Consumer) & 17 & 28 & 4.140 & 5.020 & 5.280 & 4.690 & 6.310 & 6.310 & 7.840 & 9.050 \\
\hline Seminole Co. (Country Club Hghts) & 11 & 26 & .022 & .014 & .033 & .006 & .051 & .061 & .076 & 2.043 \\
\hline Seminole Co. (Greenwood Lakes) & 11 & 25 & 1.940 & 1.975 & 2.160 & 2.190 & 2.910 & 2.870 & 3.630 & 5.461 \\
\hline Seminole Co. (Hanover Woods) & 9 & 22 & .221 & .349 & .349 & .338 & .570 & .614 & .890 & .928 \\
\hline Seminole Co. (Heathrow) & 10 & 24 & .484 & .674 & .704 & .578 & .701 & .586 & .837 & 2.878 \\
\hline Seminole Co. (Indian Hills) & 17 & 25 & 1.960 & 2.376 & 2.300 & 2.180 & 2.970 & 2.910 & 3.730 & 4.796 \\
\hline Seminole Co. (Lake Hayes) & 18 & 33 & .132 & .098 & .174 & .172 & .373 & .408 & .620 & .606 \\
\hline Seminole Co. (Lake Hayes) & 18 & 34 & .198 & .147 & .263 & .256 & .558 & .612 & .920 & .909 \\
\hline Seminole Co. (Lynwood/Belaire) & 15 & 18 & .779 & .857 & .867 & .850 & 1.220 & 1.160 & 1.470 & .170 \\
\hline Seminole Co. (Lynwood) & 16 & 19 & 0 & 0 & 0 & 0 & 0 & 0 & 0 & 1.516 \\
\hline Seminole Co. (I-4 Industrial Pk) & 7 & 25 & .202 & .224 & .224 & .229 & .249 & .260 & .265 & .464 \\
\hline Seminole Co. School Board & 15 & 20 & .112 & .116 & .116 & .120 & .119 & .106 & .199 & 0 \\
\hline Seminole Soccer Club & 8 & 22 & .140 & .140 & .140 & .140 & .140 & .140 & .140 & .140 \\
\hline Seminole Woods Assoc., Inc. & 12 & 38 & .090 & .090 & .090 & .090 & .090 & .090 & .090 & .124 \\
\hline So. States Util (Apple Valley) & 15 & 22 & .680 & .649 & .713 & .631 & .881 & .819 & 1.140 & .789 \\
\hline So. States Util (Bretton) & 17 & 23 & .212 & .200 & .214 & .199 & .290 & .270 & .377 & .278 \\
\hline So. States Util (Chuluota) & 17 & 38 & .304 & .320 & .305 & .295 & .387 & .372 & .489 & .386 \\
\hline So. States Util (Fern Park) & 15 & 24 & .102 & .100 & .092 & .087 & .112 & .102 & .127 & .093 \\
\hline So. States Util (Harmony Hms) & 15 & 24 & 0 & 0 & 0 & 0 & 0 & 0 & 0 & .093 \\
\hline So. States Util (Lk Brantley) & 14 & 19 & .028 & .040 & .041 & .031 & .046 & .051 & .056 & .031 \\
\hline So. States Util(Lk Harriet) & 15 & 20 & .126 & .150 & .143 & .127 & .173 & .163 & .209 & .139 \\
\hline So. States Util(Meredith) & 14 & 21 & .402 & .349 & .356 & .321 & .433 & .428 & .534 & .418 \\
\hline Town \& Country & 7 & 23 & 0 & 0 & 0 & 0 & 0 & 0 & 0 & .031 \\
\hline Twelve Oaks & 6 & 24 & 0 & 0 & 0 & 0 & 0 & 0 & 0 & .046 \\
\hline United Technology, Inc. & 9 & 24 & .125 & .125 & .125 & .125 & .125 & .125 & .125 & .124 \\
\hline Util of Fla (Bear Lake Manor) & 16 & 19 & .097 & .092 & .097 & .092 & .122 & .117 & .143 & .124 \\
\hline Util of Fla (Jansen) & 17 & 18 & .104 & .095 & .102 & .095 & .126 & .121 & .178 & .124 \\
\hline Util of Fla (Little Wekiva) & 15 & 20 & .037 & .024 & .025 & .022 & .028 & .027 & .040 & .046 \\
\hline Util of Fla (Oakland Shores) & 17 & 23 & .209 & .138 & .173 & .162 & .201 & .176 & .219 & .248 \\
\hline Util of Fla (Phillips/Cryst) $(9,26)$ & 9 & 26 & .094 & .086 & .084 & .092 & .122 & .117 & .152 & .031 \\
\hline Util of Fla (Ravenna Park) & 8 & 27 & .186 & .167 & .157 & .143 & .178 & .168 & .208 & .186 \\
\hline Util of Fla (Weathersfield) & 16 & 21 & .625 & .604 & .602 & .598 & .720 & .722 & .890 & .650 \\
\hline Winter Springs (WTP \#1) & 15 & 30 & 2.730 & 2.621 & 3.130 & 2.780 & 3.950 & 3.760 & 4.780 & 5.229 \\
\hline Winter Springs (WTP \#2) & 13 & 26 & .906 & 1.047 & 1.080 & .916 & 1.150 & 1.200 & 1.230 & 1.114 \\
\hline Winter Springs (WPT \#3) & 14 & 27 & .962 & .851 & .876 & .931 & 1.170 & 1.120 & 1.630 & 2.970 \\
\hline \multicolumn{11}{|c|}{ LAKE COUNTY } \\
\hline Clermont (Grandview Highway) & 22 & 1 & .741 & .611 & .637 & .720 & .926 & .850 & 1.010 & 2.429 \\
\hline Clermont (Seminole Ave.) & 21 & 1 & .693 & .730 & .717 & .522 & .910 & .841 & 1.010 & .696 \\
\hline Clermont (4th St.) & 21 & 1 & .803 & .716 & .718 & .759 & .900 & .886 & .952 & .696 \\
\hline Eustis (Ardice Place) & 6 & 4 & 1.425 & 1.282 & 1.290 & 1.260 & 1.943 & 1.740 & 2.440 & 2.915 \\
\hline Eustis (CR44A) & 5 & 5 & .528 & 2.086 & 1.910 & 1.650 & 1.660 & 1.480 & 1.820 & 4.208 \\
\hline Eustis (Hazelton Ave.) & 5 & 5 & 2.020 & .249 & .377 & .351 & .667 & .677 & .764 & .835 \\
\hline Eustis Sand Mine & 1 & 11 & 3.550 & 3.550 & 3.550 & 3.550 & 3.550 & 3.550 & 3.550 & 0 \\
\hline Florida Crushed Stone & 24 & 4 & 3.380 & 2.046 & 2.700 & 2.920 & 2.990 & 2.440 & 2.530 & 3.372 \\
\hline Florida Food Products & 3 & 3 & 2.510 & 2.510 & 2.510 & 2.510 & 2.510 & 2.510 & 2.510 & 0 \\
\hline Golden Gem & 1 & 5 & 6.152 & 6.522 & 11.600 & 8.080 & 3.310 & 2.790 & 2.650 & 7.317 \\
\hline Lake Hills Utilities & 22 & 4 & 0 & 0 & 0 & 0 & 0 & 0 & 0 & .278 \\
\hline Minneola, City of & 21 & 1 & .295 & .290 & .290 & .326 & .397 & .412 & .448 & .696 \\
\hline Montverde, City of & 19 & 5 & .187 & .148 & .148 & .163 & .224 & .188 & .265 & .340 \\
\hline Mount Dora, City of & 7 & 7 & 3.700 & 3.756 & 3.890 & 3.610 & 5.140 & 4.620 & 5.350 & 6.900 \\
\hline
\end{tabular}


Appendix C. Locations of and average daily withdrawal rates from Floridan aquifer municipal/industrial/commercial well fields used in ground-water flow model for 1988, December 1989 through May 1990, and projected 2010 simulations---Continued

[All values in cubic feet per second. OCPUD, Orange County Public Utilities Department; OUC, Orlando Utilities Commission]

\begin{tabular}{|c|c|c|c|c|c|c|c|c|c|c|}
\hline \multirow[b]{2}{*}{ Well field/well owner name } & \multicolumn{2}{|c|}{ Model } & \multirow[b]{2}{*}{1988} & \multirow{2}{*}{ 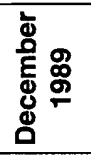 } & \multirow{2}{*}{ 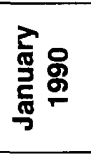 } & \multirow{2}{*}{ 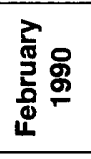 } & \multirow[b]{2}{*}{ 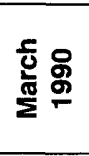 } & \multirow[b]{2}{*}{ 총용용 } & \multirow[b]{2}{*}{ 촐 } & \multirow[b]{2}{*}{$2010^{\mathrm{a}}$} \\
\hline & Row & $\begin{array}{l}\text { Col- } \\
\text { umn }\end{array}$ & & & & & & & & \\
\hline Silver Sand Co. (Clermont) & 25 & 4 & 1.910 & 2.060 & 2.200 & 2.070 & 2.170 & 2.090 & 1.950 & 1.918 \\
\hline Sundor Brands, Inc. & 8 & 7 & .032 & .030 & .030 & .020 & .030 & .020 & .020 & .031 \\
\hline Tavares, City of & 7 & 2 & 1.790 & 2.117 & 2.080 & 2.140 & 2.700 & 2.150 & 2.600 & 5.200 \\
\hline Utilities,Inc. (Amber Hill) & 24 & 1 & .148 & .165 & .204 & .163 & .239 & .229 & .316 & .294 \\
\hline Utilities,Inc. of Fla & 26 & 2 & .280 & .280 & .280 & .280 & .280 & .280 & .280 & .278 \\
\hline Vacation Village & 26 & 2 & 0 & .094 & .094 & .094 & .094 & .094 & .094 & .170 \\
\hline Wekiva Falls (Resort) & 8 & 20 & 0 & 0 & 0 & 0 & 0 & 0 & 0 & .340 \\
\hline \multicolumn{11}{|c|}{ VOLUSIA COUNTY } \\
\hline Howard S. Dorr & 5 & 37 & .028 & .028 & .028 & .028 & .028 & .028 & .028 & .031 \\
\hline Florida Power (Lake Monroe) & 3 & 29 & .147 & .131 & .132 & .122 & .132 & .132 & .137 & .232 \\
\hline FP\&L (Sanford Power Plant) & 5 & 26 & .490 & .534 & .534 & .438 & .443 & .473 & .662 & .928 \\
\hline Lemon Bluff & 6 & 37 & .044 & .044 & .044 & .044 & .044 & .044 & .044 & .092 \\
\hline Kove Assn & 5 & 35 & .024 & .024 & .024 & .024 & .024 & .024 & .024 & .062 \\
\hline Volusia Co. (Glen Abbey) & 1 & 28 & .374 & .374 & .374 & .374 & .374 & .374 & .374 & 1.176 \\
\hline Volusia Co. (Golden Bay Colony) & 3 & 54 & .130 & .130 & .130 & .130 & .130 & .130 & .130 & .124 \\
\hline Volusia Co.(Highland Ctry Est) & 1 & 27 & .164 & .261 & .261 & .428 & .465 & .453 & .445 & .712 \\
\hline Volusia Co. (Indian Harbour) & 2 & 54 & .040 & .040 & .040 & .050 & .050 & .040 & .060 & .062 \\
\hline Volusia Co. (Lake Marie) & 2 & 27 & .216 & .193 & .193 & .188 & .239 & .214 & .280 & .402 \\
\hline Volusia Co. (Terra Alta) & 1 & 27 & .056 & .050 & .050 & .050 & .070 & .060 & .020 & .077 \\
\hline Deltona & 1 & 30 & 2.253 & 2.139 & 2.211 & 2.163 & 3.120 & 3.000 & 3.840 & 3.711 \\
\hline Deltona & 2 & 29 & .751 & .713 & .737 & .721 & 1.040 & 1.000 & 1.280 & 1.237 \\
\hline Deltona & 2 & 31 & 3.004 & 2.852 & 2.948 & 2.884 & 4.160 & 4.000 & 5.120 & 4.948 \\
\hline Deltona & 2 & 32 & .751 & .713 & .737 & .721 & 1.040 & 1.000 & 1.280 & 0 \\
\hline Deltona & 1 & 30 & 0 & 0 & 0 & 0 & 0 & 0 & 0 & 2.474 \\
\hline Deltona & 1 & 29 & 0 & 0 & 0 & 0 & 0 & 0 & 0 & 1.237 \\
\hline Deltona & 2 & 31 & 0 & 0 & 0 & 0 & 0 & 0 & 0 & 1.237 \\
\hline Deltona & 3 & 33 & 0 & 0 & 0 & 0 & 0 & 0 & 0 & 3.711 \\
\hline Deltona & 3 & 31 & 0 & 0 & 0 & 0 & 0 & 0 & 0 & 1.237 \\
\hline Deltona & 3 & 34 & 0 & 0 & 0 & 0 & 0 & 0 & 0 & 1.237 \\
\hline Deltona & 3 & 35 & 0 & 0 & 0 & 0 & 0 & 0 & 0 & 2.474 \\
\hline Deltona & 3 & 32 & 0 & 0 & 0 & 0 & 0 & 0 & 0 & 1.237 \\
\hline \multicolumn{11}{|c|}{ OSCEOLA COUNTY } \\
\hline Kissimmee (Camelot West) & 36 & 16 & 1.408 & 1.930 & 1.880 & 1.820 & 2.050 & 2.010 & 2.090 & 3.342 \\
\hline Kissimmee (Parkway East) & 38 & 25 & .175 & .204 & .212 & .226 & .302 & .307 & .316 & .356 \\
\hline Kissimmee (Parkway East) & 38 & 24 & .350 & .408 & .424 & .451 & .604 & .614 & .631 & .712 \\
\hline Kissimmee (Fountain Park) & 36 & 16 & .122 & .202 & .076 & .310 & .239 & .229 & .260 & .278 \\
\hline Floribra USA, Inc. & 35 & 15 & .050 & .050 & .050 & .050 & .050 & .050 & .050 & 2.444 \\
\hline Hyatt House Orlando & 35 & 13 & .470 & .534 & .534 & .550 & .545 & .550 & .575 & 1.114 \\
\hline Kissimmee, City (Bermuda) & 36 & 20 & 3.180 & 3.802 & 3.930 & 2.640 & 4.190 & 4.310 & 5.510 & 7.580 \\
\hline Kissimmee, City (Ruby St) & 38 & 21 & 2.750 & 2.896 & 2.030 & 3.440 & 3.850 & 3.670 & 4.110 & 6.528 \\
\hline Kissimmee Good Samaritan & 40 & 16 & .324 & .366 & .366 & .326 & .387 & .366 & .417 & .789 \\
\hline Orange/Osceola Mgmt & 36 & 24 & .603 & .603 & .603 & .603 & .603 & .603 & .603 & 1.439 \\
\hline Orange/Osceola (Beunavn. Lks) & 36 & 24 & 1.766 & 1.718 & 1.830 & 1.730 & 2.140 & 2.100 & 2.520 & 4.208 \\
\hline Kissimmee NW (Osceola Serv.) & 35 & 10 & 3.160 & 1.640 & 1.640 & 1.880 & 1.930 & 2.110 & 2.330 & 3.527 \\
\hline So. States Util (Tropical Pk) & 35 & 22 & .129 & .143 & .143 & .137 & .153 & .158 & .199 & .310 \\
\hline
\end{tabular}

\section{Source Aquifer: Lower Floridan}

\section{ORANGE AND SEMINOLE COUN'TIES}

Apopka (Sheelor Oaks)

Apopka (Grossenbacher)

Apopka (NW wellfield)

Apopka (SW wellfield)

Casselberry (South)

Casselberry (N2400)

$\begin{array}{lll}16 & 16 & 3.210 \\ 14 & 15 & 2.140 \\ 12 & 14 & 0 \\ 15 & 13 & 0 \\ 18 & 27 & 1.926 \\ 15 & 26 & 1.130\end{array}$

$\begin{array}{ll}3.453 & 3.525 \\ 2.300 & 2.350 \\ 0 & 0 \\ 0 & 0 \\ 1.210 & 1.120 \\ .658 & .609\end{array}$

4.250
2.833
0
0
1.586
1.230

4.280

5.225

5.105

$2853-3.483-11371$

$\begin{array}{lll}0 & 0 & 3.249\end{array}$

$0 \quad 0 \quad 2.692$

$\begin{array}{lll}1.486 & 1.880 & 2.955\end{array}$ 
Appendix C. Locations of and average daily withdrawal rates from Floridan aquifer municipal/industrial/commercial well fields used in ground-water flow model for 1988, December 1989 through May 1990, and projected 2010 simulations--Continued

[All values in cubic feet per second. OCPUD, Orange County Public Utilities Department; OUC, Orlando Utilities Commission]

\begin{tabular}{|c|c|c|c|c|c|c|c|c|c|c|}
\hline \multirow[b]{2}{*}{ Well field/well owner name } & \multicolumn{2}{|c|}{ Model } & \multirow[b]{2}{*}{1988} & \multirow{2}{*}{ 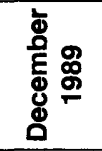 } & \multirow{2}{*}{ 놇 용 } & \multirow{2}{*}{ 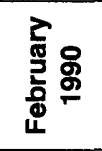 } & \multirow[b]{2}{*}{$\begin{array}{l}\text { 듕 용 } \\
\text { 띨 }\end{array}$} & \multirow[b]{2}{*}{ 흥용용 } & \multirow[b]{2}{*}{ 蛋 } & \multirow[b]{2}{*}{$2010^{\mathrm{a}}$} \\
\hline & Row & $\begin{array}{l}\text { Col- } \\
\text { umn }\end{array}$ & & & & & & & & \\
\hline Casselberry (FP2400) & 17 & 26 & .400 & .824 & .763 & .542 & .686 & .719 & 1.120 & 2.166 \\
\hline Deep South Products & 16 & 20 & .243 & .229 & .229 & .216 & .239 & .203 & .180 & .317 \\
\hline Eustis (Ardice Place-Lk.Co.) & 6 & 4 & .475 & .427 & .430 & .420 & .647 & .580 & .955 & .975 \\
\hline Maitland, City of (Keller) & 18 & 22 & 0 & 1.661 & 1.628 & 1.940 & 1.970 & 2.000 & 2.290 & 2.769 \\
\hline Maitland, City of (Wymore5A) & 18 & 22 & .318 & .431 & .422 & .396 & .417 & .420 & .467 & .364 \\
\hline Ocoee, City of (South Plant) & 23 & 13 & 0 & 0 & 0 & 0 & 0 & 0 & 0 & 4.548 \\
\hline OCPUD (Conway) & 26 & 27 & 1.570 & 1.495 & 1.510 & 1.237 & 1.817 & 1.110 & 1.020 & 5.368 \\
\hline OCPUD (Hidden Springs) & 26 & 16 & 2.190 & 2.754 & 3.767 & 3.577 & 4.739 & 4.653 & 6.226 & 0 \\
\hline OCPUD (Oak Meadows) & 23 & 16 & 1.500 & 1.982 & 2.120 & 1.850 & 1.760 & 2.885 & 2.770 & 0 \\
\hline OCPUD (Orangewood) & 30 & 18 & .913 & .818 & .931 & .908 & .967 & 1.066 & 1.069 & 2.599 \\
\hline OCPUD (Riverside) & 17 & 20 & 1.499 & 1.741 & 1.538 & 1.360 & 2.297 & 2.277 & 3.020 & 0 \\
\hline OCPUD (South Regional) & 33 & 23 & 0 & 0 & 0 & 0 & 0 & 0 & 0 & 15.470 \\
\hline OCPUD (West Regional) & 17 & 16 & 0 & 0 & 0 & 0 & 0 & 0 & 0 & 24.752 \\
\hline OCPUD (West Regional) & 17 & 17 & 0 & 0 & 0 & 0 & 0 & 0 & 0 & 6.188 \\
\hline OUC (Conway) & 25 & 26 & 10.300 & 11.588 & 11.820 & 10.654 & 13.040 & 13.086 & 14.134 & 9.498 \\
\hline OUC (Conway) & 25 & 25 & 5.150 & 5.794 & 5.910 & 5.326 & 6.520 & 6.544 & 7.066 & 4.749 \\
\hline OUC (Highland) & 22 & 23 & 10.700 & 11.022 & 9.798 & 11.442 & 13.344 & 13.104 & 17.256 & 11.232 \\
\hline OUC (Highland) & 22 & 24 & 1.790 & 1.837 & 1.633 & 1.907 & 2.224 & 2.184 & 2.876 & 1.129 \\
\hline OUC (Kirkman) & 25 & 18 & 9.690 & 11.739 & 11.750 & 12.750 & 14.919 & 15.760 & 17.800 & 17.034 \\
\hline OUC (Kuhl) & 24 & 23 & 12.990 & 12.279 & 11.799 & 11.760 & 14.590 & 14.160 & 17.520 & 17.496 \\
\hline OUC (Navy) & 22 & 27 & 2.160 & 1.366 & 5.050 & 5.340 & 5.260 & 5.890 & 6.210 & 9.901 \\
\hline OUC (Pine Hills) & 21 & 18 & 8.660 & 8.510 & 8.680 & 5.980 & 10.180 & 9.860 & 11.650 & 12.128 \\
\hline OUC (Pine Hills) & 22 & 18 & 8.660 & 8.510 & 8.680 & 5.980 & 10.180 & 9.860 & 11.650 & 18.192 \\
\hline OUC (Primrose) & 23 & 25 & 12.420 & 10.974 & 9.430 & 8.580 & 11.250 & 10.810 & 14.200 & 10.953 \\
\hline OUC (Sky Lake) & 28 & 22 & 0 & 0 & 0 & 0 & 0 & 0 & 0 & 11.834 \\
\hline OUC (Sky Lake) & 29 & 22 & 0 & 0 & 0 & 0 & 0 & 0 & 0 & 11.834 \\
\hline OUC (Orange) & 31 & 23 & 0 & 0 & 0 & 0 & 0 & 0 & 0 & 11.139 \\
\hline OUC (Pershing) & 26 & 27 & 0 & 0 & 0 & 0 & 0 & 0 & 0 & 10.829 \\
\hline Winter Garden (Palmetto St.) & 21 & 11 & 1.360 & 1.481 & 1.530 & 1.470 & 1.750 & 1.560 & 1.890 & .975 \\
\hline Winter Garden (Proposed \#4) & 22 & 10 & 0 & 0 & 0 & 0 & 0 & 0 & 0 & .975 \\
\hline Winter Park (Magnolia) & 18 & 26 & 2.810 & 2.758 & 2.950 & 3.010 & 3.430 & 3.410 & 4.230 & 5.012 \\
\hline Winter Park (Swoope) & 19 & 24 & 0 & 0 & 0 & 0 & 0 & 0 & 0 & 2.228 \\
\hline Winter Park (Wymore Rd.) & 19 & 22 & 4.560 & 4.581 & 4.660 & 4.340 & 5.460 & 5.600 & 6.440 & 4.827 \\
\hline Winter Park (University Blvd) & 20 & 27 & 7.870 & 8.628 & 8.700 & 6.830 & 9.620 & 10.160 & 12.700 & 8.076 \\
\hline
\end{tabular}

${ }^{a}$ projected 2010 pumpages provided by the St. Johns River Water Management District; all other pumpage values compiled from USGS, St. Johns River Water Management District, South Florida Water Management District, and from various city and county records. 